UNIVERSIDADE DE SÃO PAULO

FACULDADE DE ECONOMIA, ADMINISTRAÇÃO E CONTABILIDADE

DEPARTAMENTO DE CONTABILIDADE E ATUÁRIA

PROGRAMA DE PÓS-GRADUAÇÃO EM CONTROLADORIA E CONTABILIDADE

LUDMILA DE MELO SOUZA

Contratos, Transferências Voluntárias e Gestão de Políticas Públicas

SÃO PAULO

2018 
Prof. Dr. Vahan Agopyan

Reitor da Universidade de São Paulo

Prof. Dr. Adalberto Américo Fischmann

Diretor da Faculdade de Economia, Administração e Contabilidade

Prof. Dr. Ariovaldo dos Santos

Chefe do Departamento de Contabilidade e Atuária

Prof. Dr. Lucas Ayres Barreira de Campos Barros

Coordenador do Programa de Pós-Graduação em Controladoria e Contabilidade 
LUDMILA DE MELO SOUZA

\section{Contratos, Transferências Voluntárias e Gestão de Políticas Públicas}

Tese apresentada ao Programa de PósGraduação em Controladoria e Contabilidade do Departamento de Contabilidade e Atuária da Faculdade de Economia, Administração e Contabilidade da Universidade de São Paulo, como parte dos requisitos para obtenção do título de Doutora em Ciências.

Área de Concentração: Controladoria e Contabilidade

Orientador: Prof. Dr. Luiz Paulo Fávero

Co-orientadora: Profa. Dra. Patrícia Siqueira Varela

\section{Versão Corrigida}

(Versão original disponível na Faculdade de Economia, Administração e Contabilidade da Universidade de São Paulo) 
Autorizo a reprodução e divulgação total ou parcial deste trabalho, por qualquer meio convencional ou eletrônico, para fins de estudo e pesquisa, desde que citada a fonte.

FICHA CATALOGRÁFICA

Elaborada por Rafael Mielli Rodrigues - CRB-8/7286

Seção de Processamento Técnico do SBD/FEA/USP

Souza, Ludmila de Melo

Contratos, transferências voluntárias e gestão de políticas públicas /

Ludmila de Melo Souza. - São Paulo, 2018. $209 \mathrm{p}$.

Tese (Doutorado) - Universidade de São Paulo, 2018.

Orientador: Luiz Paulo Fávero.

Co-orientador: Patrícia Siqueira Varela.

1. Contratos 2. Transferências voluntárias 3. Gestão 4. Políticas públicas I. Universidade de São Paulo. Faculdade de Economia, Administração e Contabilidade. II. Título.

CDD -346.02 
Nome: Souza, Ludmila de Melo

Título: Contratos, Transferências Voluntárias e Gestão de Políticas Públicas

Tese apresentada ao Departamento de Contabilidade e Atuária da Faculdade de Economia, Administração e Contabilidade da Universidade de São Paulo como requisito parcial para a obtenção do título de Doutora em Ciências.

Área de concentração: Controladoria e Contabilidade.

Aprovado em: 08.05.2018

\section{Banca Examinadora}

Prof. Dr. César Augusto Tibúrcio Silva

Instituição: Universidade de Brasília (FACE/UnB) - externo

Julgamento: Aprovada.

Prof. Dr. Janilson Antonio da Silva Suzart

Instituição: Ministério da Transparência e Controladoria Geral da União (CGU) - externo Julgamento: Aprovada.

Prof. Dra. Maria Sylvia Macchione Saes

Instituição: Universidade de São Paulo (FEA/USP)

Julgamento: Aprovada. 

A minha mãe Vera e ao meu irmão Bruno, com todo meu amor! 



\section{AGRADECIMENTOS}

A Deus, "inteligência suprema e causa primeira de todas as coisas", pela minha existência e por realizar coisas tão maravilhosas em minha vida.

A minha mãe, pelo amor e dedicação incondicionais e por ser minha maior inspiração. A você, toda minha gratidão e todo meu amor!

Ao meu irmão pelo carinho, torcida, risadas e eterna amizade. Amo você!

Ao meu pai (in memorian), que mesmo a distância, tenho a certeza que torceu pelo meu sucesso.

À minha família, que sempre será base de tudo. Em especial, à vovó Júlia pelas orações, amor e dedicação aos seus.

Ao meu amigo e orientador prof. Dr. Luiz Paulo Fávero, minha eterna gratidão e admiração! Obrigada por acreditar em mim e ensinar-me tanto, por meio do seu exemplo como docente e, sobretudo, da sua humildade como pessoa.

À minha amiga e co-orientadora profa. Dra. Patrícia Siqueira Varela, pelo carinho e por ter me auxiliado em todo processo de amadurecimento sobre o tema, desde o início.

Ao Eduardo, pelo apoio, paciência e carinho.

Às minhas queridas amigas Amanda, Mayara e Raquel, pelo amor, carinho e torcida! Obrigada por estarem ao meu lado em todas as melhores fases!

Aos amigos César, Conceição, Gabriel e Mariana, minha gratidão. Não há palavras suficientes para agradecer todo carinho e confiança que depositaram em mim.

À Bianca, pelo carinho e amizade. Bia, amiga, ter oportunidade de cursar o doutorado com você foi um grande presente! Obrigada pelos ensinamentos, lágrimas, risadas e ouvidos!

Aos amigos e amigas que o curso de doutorado me trouxe. Em especial, agradeço às amigas Bianca Checon, Débora Zuim, Franciele Beck, Samantha Telles e Simone Fiorio.

Ao Lupa, ao Marco e à Paty, por compartilharem comigo grandes sonhos!

Aos professores com quais tive o privilégio de aprender durante todo o processo de doutoramento.

À Universidade de Brasília (UnB), minha gratidão por acolher meu sonho e pelo apoio financeiro e institucional.

Ao Centro de Estudos de Contabilidade e Governo (ContGov) da FEA/USP pela troca de conhecimento e experiências.

A todos aqueles que indesculpavelmente não foram citados, porém de suma importância para esta conquista!

\section{GRATIDÃO!}


"It is our choices that show what we trully are, far more than our abilities"

(J. K. Rowling) 



\section{RESUMO}

Souza, L. M. (2018). Contratos, Transferências Voluntárias e Gestão de Políticas Públicas (Tese de Doutorado, Universidade de São Paulo, São Paulo).

O objetivo da pesquisa é verificar como a relação entre as instituições convenentes e o governo central influencia a gestão e o monitoramento dos contratos de transferências voluntárias de políticas públicas sociais. Assim, a partir dos fundamentos de complementariedade das teorias dos custos de transação (TCE) e da agência (TA) defendido nos trabalhos de Williamson (1981) e Williamson (1983), dos modelos teóricos de McCubbins \& Page (1987) e Horn (1995) e as pesquisas empíricas de governança em contratos de serviços públicos sociais (Van Slyke, 2002; Van Slyke, 2003; Fine et al., 2016; Lecy \& Thornton, 2016), a tese analisa os aspectos dos custos de transação da governança das relações contratuais e a eficiência contratual, considerando que os contratos possuem custos associados ao desenho, à implementação, ao monitoramento (Zylberztajn; 1995). Assim, esta pesquisa foi desenvolvida considerando a relação de agência, por meio de variáveis representativas das escolhas institucionais das organizações convenentes (os tipos de organizações convenentes) e os custos de transação, por meio das variáveis relacionadas às características contratuais (convênios). Para o desenvolvimentoda pesquisa, foram coletados e analisados, individualmente, 756 convênios de transferências voluntárias. Após a confecção do banco de dados, foram utilizados os conceitos de cohort e information value assim como procedimentos estatísticos exploratórios e confirmatórios, tais como análise de correspondência, análise fatorial e modelos hierárquicos e tradicionais, lineares e não lineares. Os achados da pesquisa corroboram com a tese de que a relação de agência entre as instituições convenentes e o governo central explica (i) o repasse efetivo do governo central; (ii) a gestão, o controle e o monitoramento dos contratos firmados; e (iii) a aprovação dos planos de trabalho submetidos à análise do governo central.

Palavras-chave: Contratos. Transferências Voluntárias. Gestão. Políticas Públicas. 


\begin{abstract}
Souza, L. M. (2018). Contracts, Voluntary Transferences and Public Policies Management (PhD dissertation, University of São Paulo, São Paulo).

The aim of this research is to verify how agency relation between institutions and the federal government impacts the management and monitoring of the voluntary transference contracts of employment and solidarity economy policies. The fundamentals from theories of agency (TA) and of the transaction costs (TCE) were used supplementarly to test the hypotheses (Williamson, 1981; Williamson, 1983) with theoretical models from McCubbins \& Page (1987) and Horn (1995) and substantiating the empirical analysis of the research of contract relations governance (Van Slyke, 2002; Van Slyke, 2003; Fine et al., 2016; Lecy \& Thornton, 2016). To develop the present research, 756 voluntary transference contracts were individually collected and analyzed. After databse construction, exploratory and confirmatory statistic procedures were used, such as analysis of correspondence, and linear and non-linear hierarchical and traditional models. The research findings corroborate the thesis according to which the prior relation between institutions and the federal government helps to explain (i) the effective transference from the federal government; (ii) the management, control and monitoring of contracts signed; and (iii) the approval of work plans submitted to the federal government analysis.
\end{abstract}

Key-words: Contracts. Voluntary transferences. Management. Public Policies. 


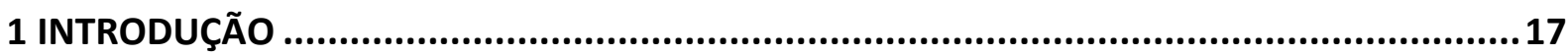

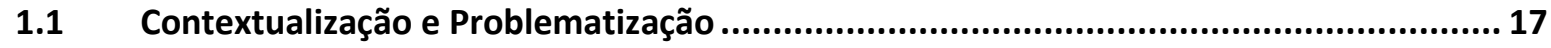

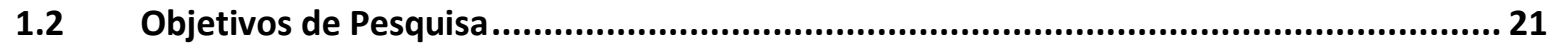

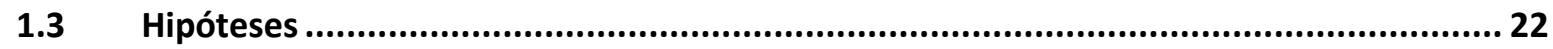

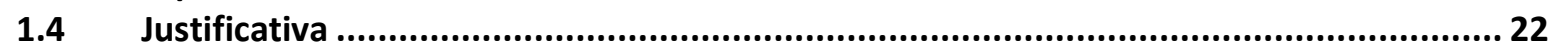

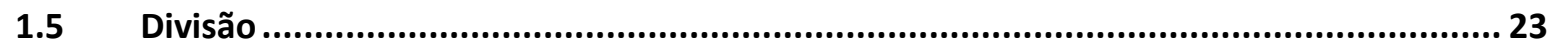

2 TEORIAS FUNDAMENTADORAS, ASPECTOS LEGAIS E NORMATIVOS DAS TRANSFERÊNCIAS VOLUNTÁRIAS \& POLÍTICAS PÚBLICAS DE EMPREGO E ECONOMIA SOLIDÁRIA.................25

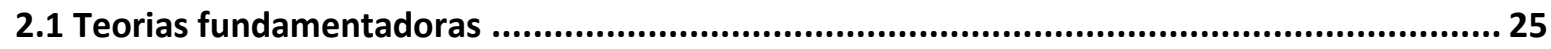

2.1.1 Teoria do Custo de Transação aplicado ao setor público.................................................... 30

2.1.2 Mecanismos de gestão, controle e monitoramento nas relações inter-organizacionais ... 38

2.1.3 Contratos de serviços sociais no setor público ............................................................... 43

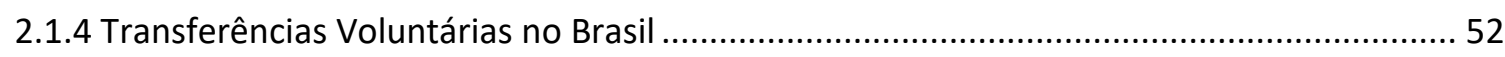

2.3 Políticas Públicas de Emprego e de Economia Solidária .............................................63

2.4 Relação entre Teoria, Objeto e Método..................................................................... 72

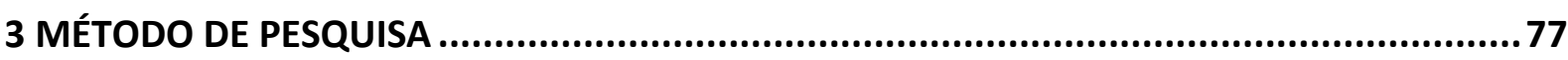

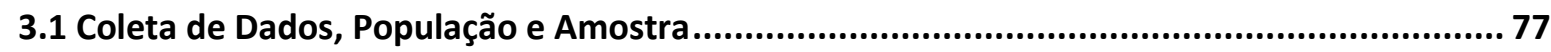

3.2 Dados e variáveis coletados para a construção do banco de dados............................... 78

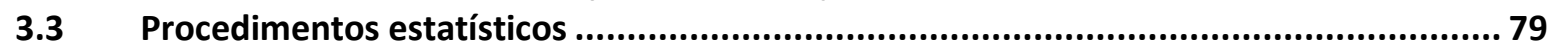

3.4 Relação entre hipóteses da pesquisa e procedimentos empíricos............................... 88

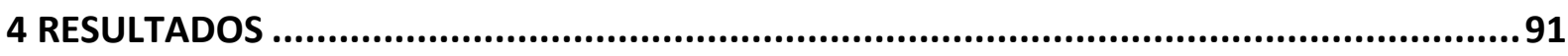

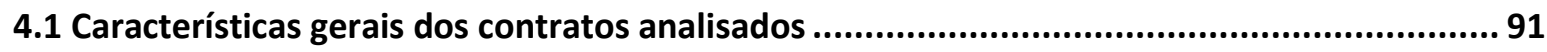

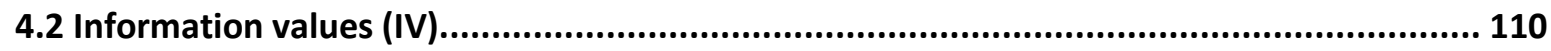

4.3Análise das técnicas confirmatórias: modelos hierárquicos e tradicionais ......................... 113

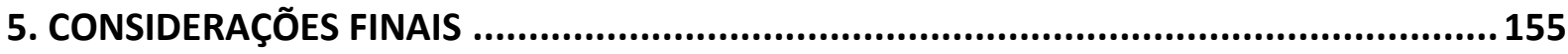

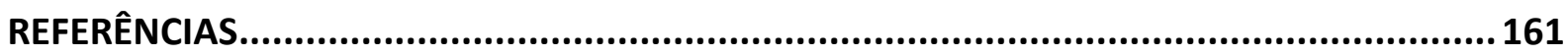

APÊNDICE A - Apectos legais e normativos das Transferência Voluntárias......................173

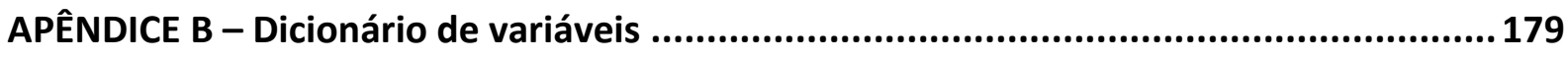

APÊNDICE C - Estatísticas descritivas \& Análises exploratórias e confirmatórias.............185 




\section{INTRODUÇÃO}

O objetivo do capítulo é apresentar a contextualização, os objetivos gerais e específicos, a tese e suas hipóteses bem como a justificativa e relevância da pesquisa.

\subsection{Contextualização e Problematização}

A contratualização é uma das ferramentas que o setor público dispõe para colocar em prática grande parte das suas políticas públicas e é estratégica para a ampliação da oferta de serviços públicos e melhoria da sua qualidade (Slyke, 2003; Pacheco, 2004; Brown \& Potoski, 2004; Heinrich \& Choi, 2007; Fine et al., 2016).

Destaca-se que a contratualizaçãode políticas públicas sociais pode ser estudada sob a ótica das políticas públicas e sob a ótica econômica (Dombeger \& Jensen, 1997). As pesquisas construídas soba ótica econômica, em especial as que utilizam os fundamentos da teoria das organizações, focam sua análise nos custos de transação e/ou na governança das relações contratuais.

De uma maneira geral, as pesquisas sobre contratualização de programas sociais de âmbito nacional e internacional entendem que: (i) as relações contratuais entre o governo central e governos locais e governo central e organizações da sociedade civil possuem problemas sérios de desenho, mas, sobretudo, de supervisão e monitoramento; (ii) os agentes públicos não possuem capacidade e treinamento adequados para gerir, controlar e monitorar os contratos firmados. Somado a isso, tem-se verificado um número cada vez menor de agentes para controle e monitoramento de contratos no governo central; (iii) os recursos provenientes do governo central estão entre as maiores fontes de receitas das organizações da sociedade civil e de alguns governos locais; e (iv) os contratos de políticas públicas sociais são firmados muito mais em critérios políticos do que critérios técnicos.

Logo, se por um lado a contratualização tem condições de contribuir para o aumento da quantidade e melhoria da qualidade dos serviços públicos ofertados, por agilizar a implementação e a revisão de prioridades vinculadas às políticas públicas; por outro, a existência de contratos incompletos, com metas e sanções pouco ou mal definidas, e as falhas de controle e monitoramento da execução contratual comprometem a efetividade das políticas públicas em nível local (Pacheco, 2004). 
As transferências voluntárias (TV) são uma modalidade de transferência que, conjuntamente com os demais tipos de transferências, auxiliam na consecução dos princípios e objetivos fundamentais da República Federativa do Brasil previstos na Constituição Federal de 1988 (CF/88), com destaque para a garantia do desenvolvimento nacional e redução de desigualdades sociais e regionais, conforme destaca Dallaverde (2015).

Dessa maneira, entende-se por transferências voluntárias federais os recursos financeiros repassados pela União a estados, distrito federal, municípios e organizações da sociedade civil em decorrência da celebração de convênios, contratos de repasse, termos de parceria, termos de colaboração e termos de fomento. Essa parceria é firmada para realização de obras e/ou serviços de interesse comum e não se origina de determinação constitucional ou legal e fundamenta-se na entrega de recursos financeiros, para suprir gastos relacionados ao objeto pretendido, a uma parte que se encarrega da execução do objeto e de uma contrapartida proporcional, geralmente financeira.

De forma prática, esses dispositivos constituem um sistema de cooperação entre os entes federados ou entre governo central e organizações da sociedade civil para execução de ações de interesse recíproco, financiadas com recursos federais.

Neste sentido, esses termos de cooperação são, em essência, contratos, uma vez que relacionam duas partes "cada qual com contribuições específicas à ação governamental”, conforme defende Pacheco (2004). Adicionalmente, os termos de cooperação vinculados às transferências voluntárias podem ser comparados a contratos de resultados, uma vez que relaciona ministérios (ou secretarias responsáveis pela formulação de políticas públicas) e entidades a ele vinculadas, prestadoras de serviços públicos (p. 1).

Para se ter uma ideia, entre o período de janeiro de 1996 e outubro de 2017, foram celebrados mais de 484.000 contratos de transferências voluntárias na esfera federal. Atualmente, o governo central possui mais de 113 mil instrumentos de transferências voluntárias, cujo montante totaliza 91,8 bilhões de reais; desse total, 56,5 bilhões já foram liberados. ${ }^{1}$

As literaturas técnica e acadêmica sobre transferências voluntárias federais destacam as seguintes questões relacionadas ao tema no Brasil: (i) as transferências voluntárias são um

${ }^{1}$ Informações disponíveis em: <http://www.transferenciasabertas.planejamento.gov.br/>. Acesso em: 07 nov. 2017. 
instrumento político de governabilidade ${ }^{2}$; (ii) há um distanciamento entre alocação e distribuição de recursos; (iii) há necessidade de melhoria do planejamento que dá origem a estes instrumentos (existe uma expectativade que estes considerem cada vez mais a necessidade local da população e a capacidade técnica das partes contratadas) e; (iv) os municípios são os entes mais dependentes das transferências voluntárias federais para a implementação dos programas públicos.

Nota-se que a literatura aponta os aspectos político-partidários e os aspectos de planejamento (a falta dele) como os principais desafios inerentes às TVs (Bijos, 2013; Amorim Neto \& Simonassi, 2013; Dallaverde, 2015; Moutinho, 2016; TCU, 2016). A perspectiva políticopartidária relaciona-se ao fato de que muitos dos recursos de TVs federais são moeda de troca por suporte eleitoral entre parlamentares e membros do executivo (de todas as esferas de governo).

Já a perspectiva vinculada à falta de planejamento claro referem-se aos projetos e planos de trabalho incompletos, com metas e objetivos insuficientemente descritos e plano financeiro distante da realidade e da necessidade do desafio público existente. Salienta-se que os aspectos político-partidários e os de (mal) planejamento supracitados podem relacionar-se entre si.

Considerando os aspectos já abordados pela literatura de contratualização e de transferências voluntárias no Brasil, observa-se que há outras perspectivas de análise ainda pouco exploradas nos estudos analisados e que podem lançar luz sobre outras razões para a baixa efetividade dos arranjos contratuais de políticas públicas sociais firmados.

A literatura de custos de transação aplicada ao setor público sustenta que a relação agenteprincipal (relação de agência) molda escolhas institucionais que regem as relações interorganizacionais (Horn, 1995; Dekker, 2004). Portanto, a maneira como os contratos são firmados, geridos e monitorados e os instrumentos institucionais utilizados para isso dependem da relação de agência existente.

São exemplos de instrumentos institucionais: (a) extensão da delegação das decisões; (b) a estrutura de governança do agente, especialmente a forma como é selecionado, o seu grau de

\footnotetext{
${ }^{2}$ Bobbio (1998) explica que se utiliza muito mais o termo oposto (não governabilidade) do que o termo governabilidade. A governabilidade e a não governabilidade são fenômenos incompletos, processos em curso, relações complexas entre componentes de um sistema politico. Citando Huntinggton, Bobbio (1998) afirma que "a governabilidade de uma democracia depende do relacionamento entre a autoridade de suas instituições de governo e da força das suas instituições de oposição” (p. 548).
} 
independência estatutária e sua forma de direito, público ou privado; (c) as regras que especificam os procedimentos que devem ser seguidos no processo decisório administrativo; (d) os mecanismos de incentivos e sanções; e (e) as regras que governam a alocação e o uso de recursos (Horn, 1995).

Assim, adota-se neste trabalho a tese de que a relação prévia entre as instituições e o governo central (em uma relação agente-principal) é essencial para explicar: (i) aprovação dos planos de trabalho submetidos à análise do governo central (antes do estabelecimento do contrato); (ii) o repasse efetivo do governo central para os contratos firmados; e (iii) a forma como se dá a gestão, o controle e o monitoramento desses contratos pelo governo central. Portanto, por meio da análise da influência da relação de agência nos aspectos elencados de (i) a (iii), pode-se entender melhor os resultados alcançados (ou não) pelos acordos de cooperação firmados.

No que se refere às características dos planos de trabalho (i), presume-se que a relação de agência determina os planos de trabalhos escolhidos. Ou seja, instituições com boas relações com o principal conseguem ter seus planos de trabalho aprovados independentemente se as metas quantitativas previstas para os serviços contratados estão alinhadas com a necessidade da política pública.

No que se alude ao repasse real do governo central (ii), suspeita-se que o indicador de repasse (relação entre o valor efetivamente liberado pelo governo central e o valor de repasse federal previamente pactuado) não é igual, em média, para os três tipos institucionais existentes (estados e distrito federal; municípios e organizações da sociedade civil). Acredita-se que essas diferenças no indicador de repasse são, em parte, explicadas pela relação de agência que esses tipos institucionais possuem com o governo central.

Portanto, organizações que possuem coalizão ${ }^{3}$ com o governo central recebem indicadores de repasse maiores, em média. Logo, dado que a maior contribuição financeira para execução das ações de interesse recíproco é do governo central ${ }^{4}$; o contingenciamento do repasse de recursos previamente pactuados afeta diferentemente as instituições contratadas e, consequentemente, os resultados alcançados nos contratos firmados.

\footnotetext{
${ }^{3}$ Acordo ou aliança política e/ou idelológica para alcance de determinado fim.

${ }^{4}$ Em média, $90 \%$ do valor conveniado é de responsabilidade do governo central e os outros $10 \%$ das contrapartes envolvidas, o que evidencia a importância da participação da União nas políticas públicas em nível local, conforme informações disponíveis em: <http://www.transferenciasabertas.planejamento.gov.br/>. Acesso em: 07 nov. 2017.
} 
Em relação à forma que se dá a gestão e os controles, depreende-se que instituições que possuem coalizão com o governo central recebem vantagens no processo de monitoramento da execução contratual, possuindo mais facilidades para incorrer em determinadas ações, tais como mudanças nos planos de trabalho, mudanças nos prazos de execução, tempestividade na análise dos relatórios e pedidos apresentados etc.

Para testar a tese exposta, uma série de contratos poderiam ser analisados. Neste estudo, foram analisados os convênios das políticas de emprego e economia solidária cujos planos de trabalho e processos de execução estavam disponíveis para a consulta.

A escolha dessas duas políticas foi feita por conveniência, considerando as seguintes motivações: (i) nível de conhecimento adequado sobre as duas políticas, principalmente no que tange à operacionalização das atividades e mensuração das metas, para análise dos convênios; (ii) o fato de serem duas políticas distintas, geridas por secretarias diferentes, mas dentro de um mesma pasta (ministério); e (iii) o fato de serem duas políticas com períodos de implantação diferentes, isto é, as políticas de emprego foram formuladas e implementadas muito antes das políticas de economia solidária.

Dado o que foi exposto, acredita-se que há contribuições a serem realizadas para a literatura de transferências voluntárias, para literatura de contratualização de serviços públicos sociais, para a gestão das políticas de emprego e economia solidária assim como ainda há aspectos empíricos a serem desenvolvidos sobre a relação entre os custos de agência e o custo das relações contratuais no setor público brasileiro. E é com base nessas lacunas que esta pesquisa foi desenvolvida.

\subsection{Objetivos de Pesquisa}

Baseado no que foi exposto, o objetivo geral da pesquisa é verificar como a relação entre instituições e governo central influencia a gestão e o monitoramento dos arranjos contratuais firmados entre eles.

Dado o objetivo geral, tem-se os seguintes objetivos específicos:

$\checkmark$ Relacionar a teoria da agência e a teoria dos custos de transação aplicados ao setor público, em uma perspectiva complementar;

$\checkmark$ Verificar os efeitos do indicador de repasse na execução e prestação de contas dos contratos firmados, em uma perspectiva da relação de agência; 
$\checkmark$ Propor um modelo de priorização de monitoramento de contratos baseado nas características dos contratos e na sua execução;

$\checkmark$ Verificar como a relação entre instituições influencia o estabelecimento das metas previstas nos contratos.

\subsection{Hipóteses}

Considerando a tese e os objetivos enunciados, as hipóteses da pesquisa são:

I. Há diferenças no estabelecimento de metas e objetivos, na execução e nos resultados obtidos pelos contratos firmados em virtude da relação entre agente e principal.

II. Os custos das transações contratuais, sobretudo os de controle e monitoramento, são influenciados pela relação entre agentes e principal.

III. As diferenças médias no indicador de repasse dos contratos são explicadas pela relação entre as instituições convenentes com o governo central. As alterações no indicador de repasse promovem alterações na forma como o contrato é executado e na sua prestação de contas.

IV. A existência de determinadas características contratuais e de execução estão relacionadas a uma probabilidade significativa de o contrato não ser cumprido.

V. As metas inicialmente estabelecidas para um mesmo serviço divergem entre os diferentes tipos de instituições convenentes.

\subsection{Justificativa}

Em termos teóricos, a pesquisa se justifica pelo fato de existirem lacunas na literatura que relaciona gestão e avaliação de políticas públicas que são objeto de transferências voluntárias. Grande parte das avaliações de políticas e transferências já realizadas são macroeconômicas e relacionam metas e indicadores de efetividade, sem, no entanto, realizar uma análise dos instrumentos de implementação dessas políticas e suas características, em nível organizacional.

Ainda, porque relaciona aspectos institucionais e de mensuração de desempenho, controle e monitoramento de contratos, tema que têm aparecido constantemente nas agendas de pesquisas do setor público (Brignall \& Modell, 2000; Modell, 2001, Slyke, 2012; por exemplo). 
Em termos empíricos, a pesquisa se justifica porque foca, em profundidade, nas características contratuais em seu nível microanalítico, isto é, considerando o convênio como a unidade de análise principal.

Em termos metodológicos, a pesquisa se justifica porque se utilizam procedimentos metodológicos em linha com a fundamentação teórica da pesquisa, ou seja, considerando a existência de hierarquia entre instituições e contratos.

Conforme foi mencionado na seção anterior, adota-se a tese de que as relações institucionais entre governo central e convenentes determinam a gestão, o nível de controle e de monitoramento e de alcance das metas dos contratos firmados.

Em termos gerenciais, a pesquisa se justifica porque, a partir das teorias fundamentadoras e da análise empírica dos dados históricos coletados, ela propõe um modelo de priorização para gestão, controle e monitoramento dos contratos de transferências voluntárias, bem como identifica os fatores que contribuem para o alcance dos objetivos desses contratos e, consequentemente, para a implementação efetiva de políticas públicas socais em nível local.

\subsection{Divisão}

A pesquisa está dividida em 5 capítulos. Após este capítulo, é apresentada a fundamentação teórica da tese, discutindo aspectos da Teoria dos Custos de Transação (TCE) aplicada ao setor público, bem como seus aspectos da relação de agência dos contratos inter-organizacionais. Ainda, no capítulo 2, são apresentados aspectos legais e normativos das transferências voluntárias bem como a descrição das políticas públicas de emprego e economia solidária no âmbito do governo central brasileiro.

No capítulo 3, são evidenciados os aspectos metodológicos da pesquisa, em especial, os protocolos utilizados para a construção dos resultados, que são apresentados no capítulo 4 .

Por fim, no capítulo 5 são apresentadas as considerações finais. 

2 TEORIAS FUNDAMENTADORAS, ASPECTOS LEGAIS E NORMATIVOS DAS TRANSFERÊNCIAS VOLUNTÁRIAS \& POLÍTICAS PÚBLICAS DE EMPREGO E ECONOMIA SOLIDÁRIA

O objetivo do capítulo é apresentar a fundamentação teórica da pesquisa. Portanto, são discutidos aspectos teóricos da Teoria dos Custos de Transação (TCE) e da Agência (TA) aplicadas ao setor público, os aspectos legais e normativos das transferências voluntárias e as políticas de emprego e de economia solidária.

\subsection{Teorias fundamentadoras}

A Teoria dos Custos de Transação (TCE) originou-se de uma série de desafios independentes, mas complementares, em economia, em direito e na teoria das organizações (Williamson,1985) e possui alguns pressupostos.

Conforme descreve Zylbersztajn (1995), a TCE possui quatro pressupostos fundamentais:

i. Há custos na utilização do sistema de preços bem como na condução dos contratos intrafirmas;

ii. As transações ocorrem em um ambiente institucional e as instituições não são neutras, isto é, o ambiente institucional corresponde a um sistema de normas, formais e informais e, sistemas de controle, que afetam o processo de transferência dos direitos de propriedade;

iii. A racionalidade limitada, pressuposto comportamental, prevê que o agente deseja otimizar, mas não consegue atender tal anseio, o que faz com que todos os contratos complexos sejam incompletos devido à limitação da racionalidade e;

iv. O oportunismo, outro pressuposto comportamental, relaciona-se à ação dos agentes buscarem, prioritariamente, seu autointeresse, o que faz com que exista a necessidade de monitoramento e, portanto, a inclusão de dispositivos contratuais de controle; e isso tem um custo.

De forma cronológica, o desafio legal foi proposto por Llewellyn (1931), que questionou a abordagem excessivamente legalista dos contratos, dominante tanto na economia quanto no direito. Para esse autor, os contratos não deveriam ser interpretados literalmente como previa a tradição, mas analisados como instrumentos capazes de prever os comportamentos das partes 
caso as ações contratadas não ocorressem conforme o esperado ou fossem objeto de questionamentos no futuro. Baseado nisso, a TCE tem como premissa a função privada e intencional dos contratos (Williamson \& Masten, 1999).

Contribuições essenciais à abordagem dos custos de transação foi realizada por Commons (1925), Commons (1934) e Coase (1937). Commons $(1925,1934)$ ofereceu uma nova interpretação para a organização econômica e elencou três características da atividade econômica: o conflito, a mutualidade e a ordem. Por isso, Commons (1934) propôs que as transações fossem a unidade básica de análise quando se examinasse os princípios de governança. Assim, o autor defendeu que uma organização econômica obtém ganhos ao prever potenciais conflitos, e que esses ganhos, provenientes das organizações, podem substituir os ganhos obtidos no mercado, conforme destacam Williamson \& Masten (1999).

Em linha, Coase (1937) aponta para a necessidade de uma definição mais clara da palavra firma (como ele mesmo denominou) bem como da sua caracterização no "mundo real”, já que a ideia de firma se vincula a dois instrumentos de análise econômica: margem e substituição. Assim, para Coase (1937), a firma consiste em um sistema de relacionamentos ${ }^{5}$. E, portanto, ele atribui à firma uma característica jurídico-contábil.

Para ele, a razão principal pela qual é rentável estabelecer uma firma é que existe um custo ao utilizar o mecanismo de preço, e que esse custo pode ser reduzido, mas não eliminado. No mecanismo de preço, os custos de negociação e conclusão de um contrato para cada transação com o mercado (transações com partes externas à firma) devem ser levados em consideração.

Portanto, a "firma" é vantajosa porque há desafios na previsão dos preços, há custos de transação e há vantagens governamentais para o estabelecimento de transações organizacionais (Coase, 1937, p. 391). Em síntese, a firma existe devido às suas vantagens em relação aos custos de transaçãocom o mercado. Em linha com Coase (1937), Barnard (1938) analisou as adaptações intencionais dos atores econômicos em hierarquia. E, assim, baseando-se em Coase (1937) e Barnard (1938), Williamson (1971) desenvolveu seus estudos acerca dos custos de transação (TCE).

Para Williamson (1971), a firma tem potencial de coordenação que muitas vezes supera o do mercado porque possui incentivos e controles provenientes das vantagens estruturais, isto é,

\footnotetext{
5"A firm, therefore, consists of the system of relationship which comes into existence when the direction of resources is dependent on an entrepreneur" (Coase, 1937, p. 393)
} 
por mais que os interesses não sejam perfeitamente harmonizados internamente, é possível limitar comportamentos oportunísticos dada a ampla variedade de instrumentos de monitoramento disponíveis, seja pelo acesso à informação, seja pelo estabelecimento de penalidades e recompensas.

Em seu artigo, Williamson (1971) discorreu sobre como os custos de transação podem ser atenuados substituindo a firma pelo mercado. A argumentação do autor considera cinco situações: mercados estáticos, incompletude dos contratos, risco de deturpação do contrato, efeito do processo informacional e adaptações institucionais. $\mathrm{O}$ autor conclui que, em tese, pelo fato de o mercado estar sujeito a falhas, o estabelecimento da firma é vantajoso. Entretanto, o autor reitera a necessidade de explorar os tradeoffs que caracterizam a organização da firma e do mercado e que variam, conforme as características das transações.

Contemporâneos a Williamson (1971), Alchian \& Demsetz (1972) desenvolveram uma pesquisa cujo objetivo foi apresentar conteúdo operacional aos custos de transação. Para isso, eles expuseram o conceito de equipe de produção. Segundo os autores, em economia, assumese que existe uma organização, seja ela mercado ou firma, que aloca a remuneração conforme a produtividade; o problema, segundo eles, é que produtividade e remuneração não são confrontadas diretamente nessa análise clássica, o que implica assumir que a produtividade gera, automaticamente, uma remuneração própria.

Dessa maneira, ao contrário do que considerava a análise clássica, Alchian \& Demsetz (1972) defendem que o sistema de remuneração é essencial para estimular a produtividade. Em uma atividade de cooperação produtiva, os autores verificaram que (1) uma variedade de recursos é utilizada; (2) o produto não é a soma de resultados separados de cada fonte em cooperação e; (3) nem todos os recursos utilizados pela equipe de produção pertencem a uma pessoa. Portanto, dada à ineficiência produtiva, o monitoramento se faz necessário para avaliação de desempenho das equipes de produção ${ }^{6}$; e isso corrobora com o conceito clássico de firma proposto por Coase (1937).

Alchian \& Demsetz (1972) propuseram uma reflexão sobre o gasto de gerenciamento com os custos de transação, já que a existência desses é irrefutável. Coase (1972) sugere que os estudos sobre as organizações considerem os diferentes arranjos contratuais e institucionais que afetam

6 Desempenho tem um conceito ambíguo porque sugere a presença de insumos e resultados (Alchian \& Demsetz, 1972). 
os custos de transação, uma vez que o contrato é o core do debate acerca dos custos inerentes às transações.

Portanto, tanto para Williamson (1975) quanto para Klein, Crawford \& Alchian (1978), a estrutura de governança reflete os atributos das transações existentes. Klein, Crawford \& Alchian (1978) focaram na possibilidade de comportamentos oportunísticos após o estabelecimento de um contrato. Os autores afirmaram que esse problema pode ser minimizado utilizando a integração vertical ou estabelecendo outros contratos.

O contrato é um arranjo institucional complexo, que envolve diferentes aspectos de uma transação econômica, tais como planejamento, compromisso, competição e governança (Williamson, 1985). Para Silva \& Saes (2007), quando Williamson (1985) considera a governança como um elemento para explicar os contratos, ele está defendendo que estrutura ótima de governança na transação econômica não é tão viesada porque os contratos são incompletos.

Para Williamson (1988), assim como a complexidade dos ativos e a estrutura de governança devem ser analisadas simultaneamente, de maneira análoga, as finançase a governança corporativas também devem ser analisadas de forma conjunta.

Dessa maneira, como a teoria da agência de Jensen \& Meckling (1976) fundamenta grande parte das pesquisas em negócios, Williamson (1988) fez uma análise comparativa entre a teoria da agência e a teoria dos custos de transação e concluiu que as duas perspectivas são fundamentalmente complementares (grifo nosso), visto que ambas auxiliam na compreensão da organização econômica. Para o autor, as duas teorias possuem duas formas. A teoria da agência (TA) é dividida em teoria formal e teoria menos formal. A teoria formal está voltada para a discussão do comportamento eficiente do risco e do seu gerenciamento. Já a teoria da agência menos formal está voltada para as tecnologias de monitoramento e sua relação com as formas de contrato e organizações. A TCEtambém possui duas vertentes: a de mensuração e a de governança das relações contratuais.

Williamson (1988) então concluiu que, apesar de governança e mensuração estarem relacionadas, é na análise de governança das relações contratuais que a teoria dos custos de transação e teoria da agência se complementam. A abordagem dos custos de transação traça a origem dos contratos na integração vertical (diferenças competitivas entre mercado e firma), 
enquanto que a abordagem de agência identifica essa origem no controle corporativo (separação entre controle e propriedade).

Assim, Williamson (1988) defende que a discricionariedade gerencial e a eficiência contratual são os principais fatores comuns entre elas.

No que concerne à discricionariedade gerencial, a TCE considera a firma como uma estrutura de governança e a TA como um nexo de contratos. A TCE tem como premissa que os agentes na estrutura de governança possuem racionalidade limitada e tendência ao oportunismo. A TA atribui ao comportamento dos agentes o risco moral e o custo de agência, em vez de oportunismo. De tal modo, para Williamson (1988), apesar de as terminologias comportamentais entre TCE e TA serem diferentes, a premissa é a mesma, em essência.

No que concerne à eficiência contratual, a TCE desenvolvida por Williamson $(1971,1985)$ volta-se para a estrutura de governança ex post ao contrato, na qual a integridade do contrato é decidida, e a TA examina os contratos de maneira ex ante, em uma análise de alinhamento de incentivos (Williamson, 1988).

Em síntese, a similaridade das duas teorias fundamenta-se nas escolhas de alocação de recursos, dentro ou fora das firmas. Fora da firma, a alocação de recursos é realizada com base no mercado e na propensão a pagar. Dentro da firma, a alocação de recursos é realizada com base em decisões unilaterais, individuais ou coletivas, geralmente baseada em uma estrutura hierárquica de gestão (Hay \& Morris, 1991).

Conforme já mencionado, a utilização da teoria dos custos de transação pode ser realizada por meio da mensuração ou da governança das relações contratuais. A teoria da agência é dividida em teoria formal e teoria menos formal. Pelo fato de as duas teorias serem complementares, conforme afirma Williamson (1988), para fins desta tese, será utilizadaa vertente da TCE relativa à governança das relações contratuais, que é complementar à abordagem menos formal da TA.

Na seção seguinte, será apresentado o arcabouço teórico desenvolvido pela literatura que aborda os desafios do setor público. 


\subsubsection{Teoria do Custo de Transação aplicado ao setor público}

Considerando os trabalhos supracitados (Alchian \& Demsetz, 1972; Williamson, 1988, por exemplo), verifica-se que uma nova abordagem de estudos das instituições foi desenvolvida entre as décadas de 70 e 80, quase 40 anos após o artigo de Coase (1937). Essa nova abordagem de estudos sobre instituições influenciou e se utilizou também de vários campos do conhecimento, tais como História, Direito, Economia e Ciência Política.

Assim, uma das primeiras aplicações da abordagem dos custos de transação em políticas públicas e economia política foi feita por Demsetz (1968), que focou nos méritos da regulação e nos contratos de franchising para serviços de utilidade pública.

Sobre este assunto, Williamson (1976) analisou a eficácia da utilização de contratos oriundos de licitação como uma alternativa à regulação para serviços de utilidade pública associados a monopólios. O autor fez uma análise dos arranjos contatuais envolvendo transações de utilidade pública na presença de investimentos duráveis, especializados e complexos e que possuem um grau de incerteza associado. $\mathrm{O}$ autor analisou ainda a estrutura administrativa necessária- tais como procedimentos de auditoria, ajustes"preços versus custo", processos formais de resolução de disputas - que refletem as características eoscustos do aparato administrativo identificado na regulação.

Levy \& Spiller (1994) fizeram uma análise comparativa do impacto político e das instituições sociais na estrutura regulatória e no desempenho do setor de telecomunicações em cinco países. Para isso, elencaram três características especiais atribuídas às utilidades públicas: (i) a maioria dos serviços de utilidade pública são caracterizados por economias de escala e de escopo; (ii) muitos dos ativos envolvidos são altamente especializados e não podem ser reaproveitados para novas funções; e (iii) os serviços têm um grande número de usuários, geralmente um número superior ao número de eleitores no país.

Sob a perspectiva da teoria econômica institucional, essas características criam problemas contratuais que impedem que as transações sejam realizadas diretamente com o mercado. Isso porque economias de escala e escopo e especificidade de ativos são características que implicam uma quantidade relativamente pequena de fornecedores. Adicionalmente, considerando o grande número de consumidores, subtende-se que os preços dos serviços são objeto de ações políticas, principalmente ao se tratar de um monopólio (Levy \& Spiller, 1994). 
Assim, a combinação de investimentos relevantes em ativos específicos e duráveis com alto nível de politização faz com que os serviços de utilidade pública sejam extremamente vulneráveis à expropriação administrativa, que possui várias formas, conforme argumenta Levy \& Spiller (1994).

Dadas as características supracitadas, os autores constataram que a obtenção de investimentos privados varia de país para país, de acordo com as instituições políticas e sociais existentes e que o desempenho de uma política ou instituição é satisfatório desde que três mecanismos complementares de controle administrativo estejam presentes: (1) restrições substantivas na discricionariedade do regulador; (2) limites formais e informais para mudanças no processo regulatório; e (3) instituições que promovam o enforcement das regras formais e informais estabelecidas.

Assim, Levy \& Spiller (1994) concluíram que as instituições políticas e sociais afetam o grau de restrição administrativa e o tipo de regulamentação, balanceando rigidez e flexibilidade. Essa conclusão é essencial para o entendimento da formulação de políticas públicas, principalmente nos países com histórico socialista, onde a falta de desenvolvimento econômico pode estar relacionada a restrições administrativas.

Portanto, o desenho regulatório tem dois componentes: governança e incentivos regulatórios. A estrutura de governança é um mecanismo que a sociedade tem para constranger a discricionariedade regulatória e resolver os conflitos que porventura surjam e estrutura de incentivo às regras que governam preço, entrada, benefícios diretos e indiretos. Tanto a governança quanto os incentivos são escolhas dos agentes políticos e relacionam-se ao legado institucional (Levy \& Spiller,1994):

As instituições legislativas e executivas são mecanismos formais para: (a) designar legisladores e tomadores de decisão e promulgar leis e regulamentos, independente do processo decisório judicial; (b) implementar essas leis e regulamentos; (c) determinar as relações entre legislativo e executivo. Já as instituições judiciárias são mecanismos formais para: (a) julgar e determinar a estrutura interna do judiciário; (b) resolver disputas de modo imparcial entre as partes privadas ou entre partes privadas e o Estado. As normas informais e costumes podem ser utilizadas também para restringir indivíduos e instituições. É característico uma disputa social entre interesses sociais e da sociedade e o balanceamento deles e, nesse caso,o papel da ideologia deve ser levando em consideração. Assim, as nações possuem aptidões e capacidades administrativas próprias. 
Nessa mesma linha, Horn (1995) desenvolveu uma estrutura teórica para as organizações do setor público. $\mathrm{O}$ autor analisou como os custos de transação influenciam as escolhas institucionais do setor público.

Horn (1995) estabeleceu dois princípios norteadores da sua análise teórica: (i) a natureza do processo decisório e (ii) as motivações e papéis dos atores envolvidos.

Por natureza do processo decisório, entende-se que as decisões são realizadas por indivíduos racionais que agem em interesse próprio (oportunismo). Para Horn (1995), interesse próprio implica dizer que, em situações de conflito, o interesse próprio irá imperar sobre o interesse da maioria. Para ele, a racionalidade é instrumental: os indivíduos perseguem suas metas da maneira mais eficiente dado um custo de informação; como a informação tem um custo, as decisões são tomadas considerando um grau de incerteza, já que é caro tomar decisões com base na totalidade das informações.

Esta premissa de escolha racional, aplicada ao setor público, refere-se à capacidade de as partes interessadas e seus agentes políticos analisarem não somente o conteúdo da política pública formulada ou norma promulgada (a partir desse ponto, somente política no texto), mas preverem aspectos relativos à implementação e enforcement, antecipando-se a possíveis disputas administrativas.

Horn (1995), em sua abordagem teórica, examina a relação entre três grupos, os quais possuem diferentes papéis e motivações: os agentes políticos (executivo e legislativo), os administradores (os burocratas) e os eleitores.

Os agentes políticos são eleitos e desempenham tanto funções legislativas quanto funções executivas. Para que uma política seja formulada, faz-se necessária a coalizão entre agentes políticos individuais; essa coalizão é soberana, uma vez que tem poder para emendar ou para revogar políticas prévias. Na estrutura teórica desenvolvida por Horn (1995), há uma simplificação útil do conceito de agente político: agentes eleitos em disputas eleitorais competitivas. O conceito de competição eleitoral é importante porque os agentes políticos devem formular políticas que aumentem seu suporte eleitoral, entretanto, essa competição eleitoral não garante que os agentes políticos irão desempenhar suas funções visando ao interesse dos seus eleitores.

Conforme afirma Horn (1995), as premissas supracitadas sobre a natureza da decisão (racionalidade e oportunismo) justificam a supremacia dos interesses dos agentes políticos em 
relação aos interesses de quem eles representam e são um dos pontos centrais da sua estrutura conceitual.

Os administradores ou burocratas são nomeados para desempenharem suas funções, são agentes administrativos da legislatura. Horn (1995) simplifica e assume que os administradores não possuem preferências políticas por si. O autor justifica essa simplificação alegando que o papel da teoria é desenvolver abstrações simples de uma realidade complexa.

Os eleitores sustentam os custos dos Estado oferecendo suporte ou oposição aos agentes políticos. Na teoria de Horn (1995), os eleitores são racionais e participam da vida política somente quando buscam satisfazer seus interesses individuais. Nesse sentido, estarão politicamente envolvidos somente quando seus benefícios estiverem sendo discutidos (racionalidade ignorante).

Apesar de existirem visões altruístas sobre as participações políticas individuais, os custos individuais inerentes à participação a limitam. Portanto, os eleitores podem exercer influência no processo de tomada de decisão administrativa de maneira coletiva, o que significa que o custo da organização e manutenção da ação coletiva é particularmente importante para análise. Portanto, a premissa da motivação e papéis dos atores envolvidos relaciona-se com os interesses de cada um desses grupos e atores.

As competições eleitorais fazem com que os agentes políticos vislumbrem oportunidades de aumentarem seu suporte político. No entanto, conforme aponta Horn (1995), essas oportunidades são limitadas, no mínimo, pelos seguintes custos de transação: (a) o tempo e o esforço necessáriospara a coalização entre os agentes na formulação de políticas (agentes políticos); (b) a capacidade de modificar as políticas existentes e influenciar a forma como serão implementadas e seu enforcement (agentes políticos); (c) a incerteza sobre o comportamento dos agentes administrativos que podem, na implementação das políticas, não atender aos objetivos e às intenções dos agentes políticos (agentes administrativos); e (d) a aversão ao risco do eleitor por não estar convencido da relação custo-benefício da política, o pode induzir a um menor suporte eleitoral ou até mesmo oposição à coalizão ou ao agente político (eleitores). 


\subsubsection{Relação entre os agentes e escolhas institucionais}

Conforme Williamson (1981), Williamson (1988) e Horn (1995), os custos de agência são um grupo de custos dentre uma infinidade de custos de transação. Considerando as premissas fundamentais da TCE aplicada ao setor público, natureza da decisão e motivação dos atores, depreende-se que, não necessariamente, o agente delegado irá agir conforme os interesses do principal, pois esse sempre buscará alcançar seus próprios objetivos.

Dessa forma, na maioria das relações, haverá custos positivos de controle e monitoramento para garantir que os termos de contrato firmado sejam cumpridos. Jensen \& Meckling (2008) definem os custos de agência como a soma das despesas de monitoramento, das de concessão de garantia e o custo residual.

Fundamentando-se nisso, depreende-se que, no setor público, ações de controle e monitoramento e de concessão de garantias são realizadas por agentes políticos na tentativa de controlar seus agentes administrativos.

A abordagem agente-principal nesse caso caracteriza a política formulada como uma corrente de relações, como entre cidadãos e agentes políticos, agentes políticos e o chefe administrativo, chefe administrativo e seu subordinado, chefe administrativo e cidadão.

Apesar de que uma decisão ter potencial de impactar as outras relações de agência, cada relação agente-principal é analisada por Horn (1995) de maneira isolada. Por exemplo, decisões que visam diminuir problemas entre eleitores e agentes políticos podem envolver constrangimento da administração e, assim, há chance de um potencial problema entre agentes políticos e chefes administrativos.

Dessa forma, dado que cada relacionamento entre agente e principal pode ser analisado de maneira isolada, mas que uma decisão singular pode impactar em mais de uma relação de agência, conforme exemplificado no parágrafo anterior, é indispensável estabelecer ações que aumentem a durabilidade das políticas formuladas, uma vez que uma política pode ser modificada pela implementação prática e pelo seu enforcement, não necessariamente por mudanças normativas de revogação ou de emenda.

Portanto, a escolha institucional vincula-se a valores e características organizacionais (ou seja, de cada tipo de organização) e é influenciada por uma série de fatores apontados na literatura: ambiente histórico, ambiente constitucional, distribuição dos custos e benefícios da política 
frente aos interesses privados, dificuldade em se relacionar metas e planos de trabalho, dificuldade de se mensurar os impactos esperados, hierarquia de decisão (Levy \& Spiller, 1994; Horn, 1995).

Em um nível mais geral, a escolha institucional consiste em atribuir direitos de decisão aos atores e determinar as regras que governam a sua discricionariedade. As escolhas institucionaischave são: (i) a extensão que as decisões são delegadas para o nível administrativo pelo agente político; (ii) a estrutura de governança do agente administrativo, especialmente a forma como é selecionado, o seu grau de independência estatutária e sua jurisdição; (iii) as regras que especificam os procedimentos que, obrigatoriamente, devem ser seguidos no processo decisório administrativo; (iv) a natureza e o grau de monitoramento, bem como a utilização de mecanismos de incentivos e sanções; e (v) as regras que governam a alocação e o uso de recursos (Horn, 1995).

Portanto, a escolha institucional considera a estrutura de governança e os arranjos financeiros envolvidos, o que envolve especificação dos direitos de decisão: por exemplo, decisões sobre quão subjetiva uma política será, o quanto de autoridade será delegada aos administradores, a participação de eleitores e grupos sociais no processo decisório relacionado à política, o nível de discricionariedade dos atos administrativos, o acesso a recursos e os critérios para a sua distribuição e utilização (Horn, 1995).

\subsubsection{Modelo Teórico proposto por McCubbins \& Page (1987) e Horn (1995)}

Horn (1995) apresentou um modelo que contém dois tipos de custo de transação e um instrumento institucional (fruto de escolhas institucionais). Considera-se, por exemplo, que os agentes políticos têm custos de tomada de decisão (LC) e custos de agência (AC) e que o grau de delegação administrativa (D) seja o único instrumento institucional disponível.

Logo, delegações amplas aumentam D, reduzem os custos de decisão dos agentes políticos e, em contrapartida, aumentam custos de agência (assim, aumenta D, reduz LC e aumenta AC).

Se se assumir que D varia em uma faixa entre 0 e 1, a questão é encontrar um valor de $\mathrm{D}$ que minimize $\mathrm{y}=\mathrm{LC}+\mathrm{AC}$. Supõe-se que $\mathrm{LC}=-\mathrm{nD}$ e $\mathrm{AC}=\mathrm{vD}$, onde $\mathrm{n}$ e $\mathrm{v}$ são o impacto do aumento da delegação em LC e em AC, respectivamente. Substituindo LC e AC na expressão de y tem-se: 


$$
Y=[-n+v] D
$$

O efeito do aumento de delegação no total dos custos de transação y é a soma dos efeitos do aumento da delegação nos custos do processo decisório (-n) e dos custos de agência (v). A mudança no total do custo de transação (dy) produzida pela mudança na delegação (dD) é:

$$
\begin{gathered}
d y=d L C+d A C \\
d y=[\delta L C / \delta D+\delta A C / \delta D] d D \\
d y=[-n+v] d D
\end{gathered}
$$

Dessa maneira, o valor total do custo de transação é minimizado quando se dela menos, $\mathrm{D}=0$ e $[-n, v]>0$.

A delegação é empregada para reduzir os custos do processo decisório quando o impacto marginal dos custos é relativamente grande, isto é, quando $n$ é maior que $v$. Assim, sua função é direcionar custos de agência quando $n$ é menor que $v$. Portanto, para minimizar os custos de transação, o uso da delegação tem de ser feito fundamentado na eficiência relativa, pois direciona custos decisórios ou custos de agência, dependendo do impacto relativo que eles têm no problema.

Os agentes políticos utilizarão esse instrumento para resolver um problema ou outro, deixando um deles não resolvido. Horn (1995) ressalta que não se pode utilizar um instrumento institucional (delegação, por exemplo) para resolver os dois problemas (custos de tomada de decisão e agência) baseando-se em Aranson et al. (1982) e McCubbins \& Page (1987).

Nos três estudos, os autores concordaram que os agentes políticos, ante a necessidade de tomada de decisão (LC) ou de custos de agência (AC), escolhem a extensão da delegação administrativa que minimiza os custos de transação. Os autores ainda concordam que esses agentes determinam outro instrumento (também fruto de escolhas institucionais), os procedimentos gerenciais $(\mathrm{P})$, como, por exemplo, estrutura de governança.

Assumindo que esses instrumentos $(\mathrm{P})$ variam entre $\{0,1\}$, os agentes políticos possuem dois instrumentos (D, P) para alcançar seus objetivos (LC, AC). Se se utilizar a mesma notação, os problemas são: 
Dado D $\{0,1\}, P\{0,1\}$ para minimizar $\mathrm{y}=\mathrm{LC}+\mathrm{AC}$

$$
\begin{aligned}
& L C=m P-n D \\
& A C=v D-q P
\end{aligned}
$$

Substituindo expressão, tem-se:

$$
Y=[m-q] P+[-n+v] D
$$

Como antes, o efeito do aumento de cada instrumento no total do custo de transação é a soma de LC e AC. Assim, tem-se:

$$
\begin{gathered}
d y=d L C+d A C \\
d y=[\delta L C / \delta P d P+\delta L C / d D d D]+[\delta A C / \delta P d P+\delta A C / \delta D d D] \\
d y=[m d P-n d D]+[-q d P+v d P] \\
d y=[m-q] d P+[v-n] d D
\end{gathered}
$$

$\mathrm{O}$ efeito marginal do aumento em $\mathrm{P}$ nos custos de transação é $m$ e nos custos de agência é $-q$. Dessa maneira, procedimentos gerenciais são mais eficazes para reduzir custos de agência, ou seja, quando $q$ é maior que $m$. Em síntese, para McCubbins \& Page (1987), a delegação é mais eficiente para redução de custos de tomada de decisão (LC) enquanto que os procedimentos gerenciais são úteis para controlar os custos de agência (AC).

De tal modo, Horn (1995) ressalta que muitas questões teóricas apresentadas são manifestações condicionais de decisões institucionais dos agentes em nível administrativo. Reitera também que, apesar das simplificações existentes no seu modelo teórico, ele é útil pois fundamenta-se na realidade existente.

A TCE influenciou uma série de pesquisas sobre o setor público no âmbito internacional. Nas próximas seções, são apresentados trabalhos empíricos cuja fundamentação teórica fundamental são os custos de transação, sobretudo de contratos de serviços sociais, objeto desta tese. 


\subsubsection{Mecanismos de gestão, controle e monitoramento nas relações inter-organizacionais}

A literatura de gestão tem desenvolvido frameworks acerca de controles gerenciais em relações inter-organizacionais (IOR) a partir dos pressupostos (ou gaps) da Teoria dos Custos de Transação (TCE).

Dessa maneira, essa literatura foca em quatro grandes questões relacionadas à relação entre organizações: (1) as motivações para formação da relação; (ii) a escolha da estrutura de governança; (iii) a efetividade; e (iv) o desempenho das IORs.

Segundo Dekker (2004), a questão dos controles está diretamente relacionada com a escolha da estrutura de governança e os possíveis impactos no desempenho das organizações. Assim, os autores dividem os mecanismos de controle em formais e informais (Smith et al., 1995; Dekker, 2004; Cuganesan, 2006; Cuganesan, 2007).

Os mecanismos de controle informais referem-se a mecanismos de controle social, relacionados à cultura e sistemas, que influenciam os membros da organização e são essencialmente baseados em estruturas que induzem a autorregulação (Ouchi, 1979).

O controle informal por meio de mecanismo social está relacionado à confiança. Conforme define Zucker (1986), confiança é a composição de expectativas positivas sobre a intenção ou comportamento de outras partes em situações de risco ou vulnerabilidade, o que Cuganesan (2007) definiu como um processo calculado, construído em base social, derivado de informações e experiências prévias em relação a outra parte.

Assim, Sako (1992) identificou três tipos de confiança: (i) contratual, que é a expectativa de que a outra parte irá honrar os arranjos realizados, sejam eles orais ou escritos, embasados em padrões morais e na ética; (ii) confiança na competência, que é a expectativa de que a outra parte possui habilidade e capacidades necessárias para desempenhar o acordo firmado; e (iii) confiança na boa vontade, que se refere à expectativa de que as partes estão comprometidas a tomarem iniciativas em relação a novas oportunidades, além e apesar do que foi previamente estabelecido.

Os mecanismos de controle formais consistem em obrigações contratuais e outros instrumentos formais da organização. Podem ser divididos em mecanismos de controle por resultado e mecanismos de controle por comportamento ou conduta (Ouchi, 1979). 
Segundo Dekker (2004), os mecanismos de controle formal por resultado especificam os resultados a serem realizados pela IOR e monitoram o grau de alcance desses objetivos. Os mecanismos de controle formal por comportamento preveem a comparação entre as ações observadas com aquelas previamente definidas, por meio da análise dos planos de trabalho, das normas e padrões, dos procedimentos operacionais.

Dessa maneira, são exemplos de monitoramento de conduta a confecção de relatórios, autorização escrita para modificações em planos e procedimentos, análise de informação contábil e orçamentária, controle de custos e de qualidade, cumprimento de disposições legais. Das e Teng (1998) defendem que os mecanismos de controle por conduta são essenciais para assegurar que as ações realizadas estejam em conformidade com aquelas desejáveis.

A literatura defende que um mix de controles pode ser aplicado para monitoramento das relações entre entidades, isto é, podem estar presentes tanto os controles formais quanto os informais (Ouchi, 1979; Williamson, 1983; Williamson, 1985; Cuganesan, 1999; Dekker, 2004; Cuganesan, 2007).

Neste trabalho, serão considerados os mecanismos de controle formais como o principal fundamentador teórico da parte empírica da pesquisa. Conforme mencionado, os controles contábeis são uma espécie dos mecanismos de controle formais e se dão por meio de (i) controle de resultados ou (ii) controle de comportamento, quando os resultados e os comportamentos são objeto de mensuração e neste ínterim, insere-se a informação contábil.

Dessa maneira, o papel da contabilidade para o monitoramento das relações interorganizacionais é amplamente discutido e analisado, tanto pelas abordagens gerenciais supracitadas (Sako, 1992; Tomkins, 2001; Dekker, 2004; Cuganesan, 2006; Cuganesan, 2007) quando pela abordagem dos usuários externos, apresentada a seguir (Feltham, 1968, Zimmermann, 1977; Baber, 1983, por exemplo).

Scott (2009) elenca três abordagens utilizadas nas pesquisas em contabilidade para usuários externos: a abordagem da informação, a abordagem dos contratos e a abordagem da mensuração.

A abordagem da informação está relacionada à relação entre os números contábeis e o mercado. A abordagem da mensuração analisa a relação entre a informação contábil, o desempenho da entidade e o seu valor. A abordagem dos contratos analisa o papel dos números contábeis nos contratos entre várias partes. Essa abordagem defende que a contabilidade e a auditoria exercem 
um papel importante sobre os termos contratuais e de monitoramento, porque os números contábeis são utilizados nos contratos e porque a auditoria monitora possíveis não cumprimentos desses contratos (Watts \& Zimmermann, 1986; Scott, 2009).

Assim, na abordagem dos contratos, a contabilidade é uma parte integral dos contratos que definem a firma. Esses contratos incluem a organização das firmas e suas estruturas de avaliação e compensação. Assim, a magnitude dos custos contratuais explica as escolhas organizacionais e as práticas contábeis (Watts \& Zimmerman, 1986).

Os contratos não irão reduzir os custos de transação a não ser que as partes possam determinar se os termos firmados estão sendo cumpridos, conforme argumentam Watts \& Zimmerman (1986). Portanto, a literatura de direitos de propriedade sugere que a contabilidade possui um importante papel tanto nos termos contratuais quanto nos de monitoramento.

A atribuição de importância à contabilidade no monitoramento dos contratos nas relações entre gestores não é nova nos estudos de contabilidade. Watts \& Zimmerman (1986) identificaram uma série de textos em contabilidade gerencial que discutem o uso de informação contábil para reportar desempenho de gestores e transações, bem como sobre o papel dos relatórios de auditoria na análise dos controles internos e outros instrumentos para restrições de ações de gestores e funcionários.

A demanda por contabilidade aumenta a confecção de contratos que reduzem os custos de transação, entre eles os de agência. A redução desses custos de transação será efetiva se houver monitoramento e enforcement. Dessa forma, a teoria positiva da contabilidade tenta entender e antecipar as escolhas institucionais das políticas contábeis.

Portanto, o papel da contabilidade no monitoramento de contratos é parte de todo um processo de governança corporativa. Isso porque um contrato eficiente minimiza o oportunismo, motivando os gestores a agir conforme os interesses dos vários stakeholders institucionais.

Vale salientar que a teoria da contabilidade enfatiza a necessidade de investigação empírica para determinar o tradeoff entre oportunismo e flexibilidade dos gestores, que varia de instituição para instituição, a depender das variáveis relacionadas à governança corporativa e contextuais (Scott, 2006).

Nesse sentido, existe uma enorme quantidade de estudos sobre as escolhas contábeis e suas motivações. O setor privado possui um corpo de literatura e achados empíricos robustos no 
âmbito da teoria positiva da contabilidade, conforme aponta Scott (2009). Os pesquisadores da área de contabilidade governamental também têm estudado as escolhas contábeis e a sua qualidade; no entanto, poucos estudos empíricos nessa linha levam em consideração os aspectos institucionais do governo, conforme salienta Cheng (1992).

Pesquisadores como Zimmerman (1977), Baber (1983), Baber \& Sem (1984), Evans \& Patton (1983) e Evans \& Patton (1987) têm reconhecido a correlação entre economia, política e escolhas contábeis. Portanto, políticas contábeis do Estado e decisões de evidenciação de informações financeiras são influenciadas por uma série de fatores de contexto político. Aliado a isso, a literatura de ciência política tem introduzido uma série de variáveis sociais, econômicas, culturais, políticas e institucionais para explicar as informações sobre políticas públicas em diferentes sistemas políticos.

De maneira semelhante, a literatura de escolha pública fornece uma análise sobre ambientes políticos complexos e sua relação sobre como e porque os eleitores, grupos de interesse, políticos e burocratas podem ser considerados atores dominantes nas decisões governamentais para a adoção de critérios e procedimentos contábeis (ver, por exemplo, Zimmerman, 1977). Assim, as escolhas contábeis governamentais não são somente consequência de fatores políticos ou econômicos, mas o resultado de decisões normativas, governamentais e burocráticas moldada pelos interesses de eleitores, grupos de pressão, demandas e restrições externas, competição e forças institucionais.

Considerando a quantidade de custos de transação nas organizações públicas, Zimmerman (1977) e Baber (1983) defendem que em política, os contratos entre as partes políticas, administradores e os grupos de interesse delineiam a estrutura conceitual de agência e por isso a contabilidade, como instrumento de monitoramento, pode ser demandada quando há uma competição política mais acirrada.

Baber (1983) defende que os agentes políticos eleitos se utilizam de instrumentos de monitoramento para evidenciar que suas promessas pré-eleição foram executadas, o que aumenta seus incentivos para cumpri-las dada a competição eleitoral futura e que existe um contrato entre esses agentes e seus eleitores (ou grupos de interesse, por exemplo) de divisão de benefícios das políticas públicas.

Dessa forma, o autor defende que, pelo fato de os auditores terem acesso estatutário às informações de execução de políticas públicas, a relação custo/benefício de monitoramento é 
mais favorável quando comparada com outras fontes alternativas de monitoramento, como, por exemplo, a imprensa.

Baseado nisso, Baber (1983) identifica variáveis que podem influenciar os custos de monitoramento dos contratos: (1) o número e a magnitude de transferências de recursos, isto é, quanto maior o volume de recursos, maior a competição política entre os envolvidos e, portanto, maior os custos de monitoramento dos contratos; (2) o aumento da dívida pública também aumenta o incentivo dos agentes por monitoramento; e (3) o número de congressistas e a receita de um determinado ente aumenta o incentivo por monitoramento de contratos.

Baber \& Sen (1984) desenvolveu um estudo sobre o papel da contabilidade e dos relatórios contábeis no setor público. Para os autores, os agentes políticos eleitos adotam métodos de divulgação de informações contábeis para reduzir os custos de transação resultantes das relações contratuais entre os agentes eleitos e os grupos de interesse. Dessa forma, os agentes políticos reportam informações por dois motivos: (1) o custo de produzir e divulgar informações é reduzido quando se aumenta a quantidade de usuários e opções de divulgação; e (2) os incentivos que os agentes políticos possuem para regular o reporting financeiro são relevantes para manutenção do suporte político.

Um padrão de reporting financeiro entre os agentes políticos e os grupos de interesses é preferível pelas partes contratantes no momento da negociação ou de enforcement de políticas públicas. Desta maneira, o ambiente político influencia a relação custo/benefício de se adotar a informação contábil.

Nessa linha, Ingram (1984) estudou a relação entre os fatores econômicos e as variações das práticas contábeis no setor público e concluiu que as características dos Estados influenciam na quantidade de informação contábil utilizada. Portanto, a contabilidade como meio de informação, pode ser útil para avaliação de custos e benefícios no controle e monitoramento das atividades públicas. Baseado nisso, o autor apontou duas características que influenciam a utilização da informação contábil: as coalizões políticas e as características institucionais.

No que concerne às coalizões, o autor constatou que qualquer instrumento que contribua para a redução dos custos de transação aumenta a demanda por informações sobre quantidade e utilização de recursos, ou seja, por informações contábeis. Em síntese, os eleitores e grupos representativos demandam informações que possibilitem o monitoramento das ações dos políticos eleitos, uma vez que a análise desse comportamento pode influenciar o processo 
eleitoral seguinte. Em relação às características institucionais, Ingram (1984) defende que um sistema de informações contábeis ameniza os impactos da delegação realizada aos agentes administrativos porque propicia o seu monitoramento.

Cheng (1992) relacionou escolhas institucionais, ciência política e a escolha de evidenciação contábil governamental. A pesquisa da autora corroborou com as de Baber \& Sem (1984) e Ingram (1984) e constatou que a escolha contábil depende do ambiente político e das forças institucionais, demonstrando mais uma vez a importância da contabilidade como instrumento de controle e monitoramento de contratos.

Nessa linha, Carruthers (1995), Froud, Shaoul \& Williams (1998) e Bãlutã (2012) afirmam que vários trabalhos científicos têm demonstrado a riqueza e a significância da contabilidade para as organizações e sociedade. Apesar disso, há necessidade de mais pesquisas empíricas que considerem a informação contábil como instrumento de avaliação das escolhas institucionais e das políticas públicas.

\subsubsection{Contratos de serviços sociais no setor público}

Os contratos são moldados segundo o relacionamento entre as partes, argumentou Cuganesan (2007) e, buscam minimizar possíveis comportamentos oportunistas por meio de mecanismos ex ante (vinculaçãode uma das partes a uma obrigação) e ex post (estabelecendo sanções nos casos de não cumprimento do acordo), conformeapresentou Williamson (1983).

No setor público, contratualização abrange tanto os contratos com entidades e agentes externos, provenientes ou não de processos licitatórios,quanto contratos realizados entre entidades do próprio setor público e entre esferas de governo. Dessa maneira, esses contratos envolvem arranjos sobre operações de gestão, de compra e venda de bens e serviços, de empréstimos, entre outras (Boston, 1996).

No que concerne aos contratos entre esferas federativas ou entre o setor público e organizações da sociedade civil, Kramer \& Grossman (1987) denominaram esse fenômeno como estado contratual ou federalismo sem fins lucrativos: separação do provedor principal (isto é, aquele responsável pelo repasse financeiro total ou da maior parte dos recursos previstos no contrato) do fornecedor do serviço público. Slyke (2002) chamou essa ação de devolução, isto é, o processo de transferir o poder e a responsabilidade pela entrega de serviços públicos do governo 
central para o governo local, o que diminui o tamanho físico e os custos do governo central e mantém, em tese, o alto padrão dos serviços prestados.

Dombeger \& Jensen (1997) dividem os argumentos sobre a contratualização no setor público em duas grandes perspectivas: (i) a das políticas públicas, que aborda temas como o papel do Estado, os problemas de accountability decorrentes da ação do setor privado na coisa pública e questões sobre direitos dos cidadãos e impactos na democracia; e (ii) a perspectiva econômica, que apresenta dentre os principais argumentos fundamentadores a redução de custos, a melhora dos serviços oferecidos, o aumento da flexibilidade de gestão, a expertise da parte envolvida e, finalmente, a diminuição das ineficiências vinculadas ao poder público central (ver, por exemplo, Savas,1977; Boston, 1996; Slyke, 2003).

É importante salientar, no entanto, que o sucesso da contratualização está vinculada às características das operações contratadas, quais sejam, o tipo de produto ou serviço a ser prestado, a existência de um mercado amplo e competitivo, a capacidade de transparência e o exercício do controle social, bem como a existência de ferramentas de avaliação e mensuração.

Kettl (2011) elenca três pontos fundamentais acerca da utilização dos contratos de devolução: (i) a confiança de que a parte envolvida é capaz de realizar uma atividade que é própria do setor público; (ii) o entendimento dos desafios referentes à interação com mercado de serviços e com organizações do terceiro setor; e (iii) a troca de papéis imprescindível: pois o governo central deixa de ser fornecedor de produtos e serviços públicos e passa a ser supervisor das ações (muitas vezes observáveis por meio de "proxies" de produtos e serviços) de quem executa o trabalho contratado.

Nesse aspecto, Dombeger \& Jensen (1997) elencam as condições teóricas, as quais aumentam as chances de a contratualização no setor público ser bem-sucedida:

I. O contrato é mais bem-sucedido se a magnitude e a especificidade dos ativos envolvidos no fornecimento do serviço são menores. Para o autor, apesar de especificidade e tamanho de ativos possuírem efeitos independentes na contratação, o efeito simultâneo dessas duas características é determinante para o sucesso do contrato.

II. O contrato é mais bem-sucedido se as características qualitativas pouco ou não passíveis de descrição (descriminação) são menos significativas. 
III. O contrato é mais bem-sucedido se há maior disponibilidade de competidores atuais ou potenciais no mercado.

Um outro aspecto elencado pela literatura sobre o sucesso contratualização no serviço público é o monitoramento. Problemas de monitoramento são apontados como a principal causa de falha contratual no setor público. As falhas contratuais estão relacionadas a um arranjo contratual malfeito ou a um monitoramento aquém do necessário.

Brown, Potoski \& Slyke (2006) destacaram os seguintes pontos corroborados pela literatura sobre estado contratual: (1) A contratualização é o maior desafio dos gestores públicos; (2) Os gestores públicos nem sempre têm discricionariedade sobre a decisão de contratação e são estimulados a decidirem baseando-se nos valores dos atores políticos e em condições nem sempre ótimas; (3) Os gerentes públicos encarregados da contratualização operam em ambientes politicamente densos e realizam certos balanceamentos com vistas a equilibrar os valores das partes interessadas e concorrentes; e (4) A contratualização pode aprimorar o serviço fornecido ou ser desastrosa e, uma coisa ou outra depende das condições competitivas do mercado e da eficácia gerencial.

O nível de completude dos contratos também está sendo analisado pelos pesquisadores de gestão pública. Inicialmente, a ideia de completude contratual foi estabelecida pela literatura voltada ao setor privado (ver, por exemplo, Hart e Olstrom, 2016). Para o setor público, no entanto, um contrato completo é aquele no qual os gestores públicos procuram mitigar contingências imprevistas estabelecendo cláusulas específicas em seu conteúdo. Brown, Potoski \& Slyke (2007) apontam que a completude dos contratos governamentais é uma função de vários componentes que permeiam as atividades principais e a especificidade dos resultados. Assim, os contratos são mais ou menos completos baseados no número e na especificidade dos recursos de governança que determinam como as trocas ocorrerão e como as partes interagirão durante a vigência do contrato.

Dessa forma, contratos mais completos são desejáveis quando os custos de renegociação são altos; se a duração do contrato é limitada ou; se existe um pequeno ganho em se modificar os termos contratuais. Por outro lado, se a duração do contrato for extensível a um longo período, se as atividades possuem alta complexidade e há ganho na modificação dos termos arranjados, esperam-se arranjos contratuais mais incompletos (Brown, Potoski \& Slyke, 2007). Destaca-se que algumas pesquisas sobre essa abordagem teórica entendem que a incompletude dos 
contratos é uma ferramenta relacional construída pela confiança entre as partes (ver, por exemplo, Fernandez, 2005).

Assim, os gestores públicos, de todas as esferas de governo, estão envolvidos não somente em gerenciar programas públicos, pessoas e contratantes, mas também em coordenar ações e evidenciar informações. Portanto, o grande desafio desses gestores e dos pesquisadores da área é entender quais abordagens e práticas são mais efetivas em um ambiente em que prevalece cada vez mais os contratos de prestação de serviços públicos.

Dadas que as características contratuais e a confiança entre as partes são determinantes para que a contratualização seja vantajosa para o setor público, não é difícil inferir que algumas características são menos nítidas quando se trata de pactos que visam a entrega de produtos e serviços ligados a políticas públicas sociais, tais como saúde, habitação, educação e trabalho, por exemplo (DeHoog, 1984; Kramer \& Grossman, 1994; Wallin, 1997; Slyke, 2003).

Isso porque as políticas públicas sociais são constituídas de programas que possuem (i) metas e resultados complexos de se avaliar e mensurar, (ii) clientes com diferentes níveis de necessidade, de demanda e de motivação e (iii) o predicado da continuidade.

Slyke (2002) destaca que a contratualização de serviços sociais representava aproximadamente $72 \%$ dos contratos de entrega de serviços públicos nos EUA. Em 2001, o departamento de transparência do governo americano revelou que $88 \%$ dos fundos contratados estavam em nível estadual e que grande parte desses contratos eram reembolsáveis. Adicionalemente, somente um quinto deles realizaram pagamentos condicionais ao desempenho apresentado pelo contratado (Heinrich \& Choi, 2007). Em 2009, o órgão de transparência reportou que o governo central americano repassou mais de 200 bilhões de dólares por meio de contratos para as entidades privadas sem fins lucrativos (Lecy \& Thornton, 2016).

Dessa forma, os atributos supracitados, relativos à complexidade inerente à execução dos programas sociais, faz com que as partes interessadas nesse tipo de prestação de serviço sejam raras, o que promove arranjos pactuados principalmente com outras esferas do setor público (entre governo central e os governos locais, por exemplo) e com entidades privadas sem fins lucrativos.

Se por um lado, em tese, a contratualização pode promover eficiências econômicas, inovação e diversidade, uma vez que as entidades participantes do arranjo contratual estão mais próximas dos clientes finais dos programas públicos e, teoricamente, apreenderiam mais facilmente suas 
necessidades (Slyke, 2003; Pacheco, 2004, por exemplo), por outro lado, Slyke (2003) aponta que, na prática, a falta de um mercado competitivo impacta tanto na capacidade administrativa dos atores envolvidos - setor público e setor privado sem fins lucrativos - bem como na mensuração do desempenho das atividades realizadas que, geralmente, são definidas precariamentee com mecanismos de transparência e controle social elementares, além da discrepância entre o planejamento dos programas sociais e os procedimentos e práticas implementados.

Adicionalmente, o autor destaca a dependência financeira que as partes envolvidas possuem dos recursos do governo central; o que acarreta desvio de missão, falta de profissionalismo e diminuição da qualidade do serviço prestado (Slyke, 2003). Para Brown \& Potoski (2004), há uma necessidade de se discutir como os gestores fazem para administrar a competição (ou falta dela) do mercado e ampliar seus conhecimentos sobre contratos bem-sucedidos.

As pesquisas empíricas sobre a contratualização de serviços públicos sociais têm raízes nas teorias dos custos de transação e suas correlatas: da escolha pública, da agência, das redes, dos direitos de propriedade, dos contratos incompletos e dos processos colaborativos, conforme destaca Brown \& Potoski (2004), Brown, Potoski \& Slyke (2007) \& Gazley (2008). Nesse ínterim, Slyke (2003) aponta que a maioria dessas pesquisas são conceituais, prescritivas e baseadas em casos específicos sem, no entanto, "utilizar coleta de dados primária com análises empíricas e generalizáveis" (tradução nossa, p. 298).

A Ilustração 1 representa o estado da arte das pesquisas sobre contratualização de serviços públicos sociais ${ }^{7}$. Sobre os trabalhos elencados, é possível verificar que eles são unânimes em constatar que:

I. As relações contratuais entre o governo e os governos locais e/ou entidades privadas sem fins lucrativos possuem problemas sérios de desenho, mas principalmente, de supervisão e monitoramento;

II. Os agentes públicos não possuem capacidade técnica e treinamento para analisar o desempenho dos contratos firmados e estão presentes em um número cada vez menor nas entidades do setor público;

\footnotetext{
${ }^{7} \mathrm{~A}$ revisão de literatura foi limitada aos artigos que estavam escritos lingua inglesa.
} 
III. Os recursos provenientes do governo estão entre as maiores fontes de receitas das entidades privadas sem fins lucrativos;

IV. Os contratos são frequentemente firmados baseados muito mais em critérios políticos do que critérios de custo-benefício;

Dessa maneira, alguns assuntos ainda precisam ser aprofundados pelos pesquisadores de contratualização de serviços sociais: (i) como e quais características do contratado (agente) interferem no cumprimento das cláusulas contratuais estabelecidas com poder público central (principal); (ii) como e quais características dos próprios contratos aumentam as chances de seu cumprimento; (iii) como e quais os mecanismos de controle e monitoramento garantem o êxito desses contratos, aumentando a probabilidade de que sejam cumpridos integralmente.

Baseado nos gaps da literatura, supracitados nesta pesquisa, o risco de não execução dos contratos será analisado em duas vertentes: considerando as características das instituições contratadas (agentes) pelo governo central (principal) e, em virtude das características do próprio contrato, considerando seus custos de transação.

Portanto, a fundamentação teórica para o desenvolvimento empírico da pesquisa baseia-se na conexão das teorias do custo de transação (TCE) e da agência (TA), nas partes que Williamson (1988) as considera complementares, fazendo uso do modelo teórico desenvolvido por McCubbins \& Page (1987) e Horn (1995) para o setor público, que relaciona os custos de transação e os custos de agência com escolhas institucionais.

De forma prática, as escolhas institucionais se traduzem em instrumentos institucionais de governança, tais como grau de delegação e tipos de procedimentos gerenciais, esses últimos que são mecanismos de gestão, controle e monitoramento entre organizações (interorganizacionais), pois se dá por relações entre setor público central e o setor público local e entre setor público central e organizações da sociedade civil. 


\begin{tabular}{|c|c|c|c|c|c|}
\hline Ano & Autores & Objeto & Metodologia & Foco da pesquisa & Resultados encontrados \\
\hline 1984 & DeHoog & Michigan & $\begin{array}{c}\text { Entrevistas, } \\
\text { Documentos e } \\
\text { Dados de arquivo }\end{array}$ & Gestores públicos & $\begin{array}{l}\text { Falta de competição na escolha dos contratados, presença de incentivos burocráticos, fracos mecanismos de accountability, tomada de } \\
\text { decisão política e falta de capacidade administrativa foram verificados no processo de contratualização de serviços sociais. }\end{array}$ \\
\hline 1991 & Bernstein & $\begin{array}{l}\text { Cidade de Nova } \\
\text { Iorque }\end{array}$ & $\begin{array}{l}\text { Entrevistas e } \\
\text { Documentos }\end{array}$ & $\begin{array}{l}\text { Gestores das entidades } \\
\text { privadas sem fins } \\
\text { lucrativos }\end{array}$ & $\begin{array}{l}\text { Para os gestores, o contrato é um "jogo". Existência de mecanismos ambíguos de accountability na gestão dos contratos. Falta de expertise } \\
\text { em gestão pública por parte dos contratantes. Processo possui influências políticas. }\end{array}$ \\
\hline 1991 & Saidel & Nova Iorque & $\begin{array}{l}\text { Entrevistas e } \\
\text { Questionários }\end{array}$ & $\begin{array}{l}\text { Gestores públicos e de } \\
\text { entidades privadas sem } \\
\text { fins lucrativos }\end{array}$ & $\begin{array}{l}\text { Há uma interdependência financeira e de expertiseentre governo e contratados. Existência de networks políticos nas entidades privadas. } \\
\text { Divergências de metas entre o governo e seus contratados.As entidades privadas constituem e demandam as agências públicas. }\end{array}$ \\
\hline 1993 & Smith \& Lispky & Massachusetts & $\begin{array}{c}\text { Entrevistas, } \\
\text { Documentos e } \\
\text { Dados de arquivo }\end{array}$ & $\begin{array}{l}\text { Oficiais do Estado e das } \\
\text { entidades privadas sem } \\
\text { fins lucrativos }\end{array}$ & $\begin{array}{l}\text { Dependência dos recursos públicos por parte das entidades privadas. As entidades desenvolvem estratégias de adaptação em resposta à } \\
\text { diminuição do repasse do setor público. As entidades privadas atuam e são vistas como agentes do estado. }\end{array}$ \\
\hline 1996 & Smith \& Smyth & Carolina do Norte & $\begin{array}{c}\text { Entrevistas, } \\
\text { Documentos e } \\
\text { Dados de arquivo }\end{array}$ & Participantes contratados & $\begin{array}{l}\text { Falta de competição na escolha dos contratados.Mensuração de desempenho e existência de accountability formal. Gerenciamento } \\
\text { baseado na verdade, reputação e relações de longo prazo com o governo (confiança). }\end{array}$ \\
\hline 1998 & Meyers et al. & Califórnia & $\begin{array}{c}\text { Observações de } \\
\text { campo, } \\
\text { entrevistas e } \\
\text { documentos } \\
\end{array}$ & $\begin{array}{c}\text { Agências de emprego, } \\
\text { observação de transações } \\
\text { com os trabalhadores } \\
\text { usuários } \\
\end{array}$ & $\begin{array}{l}\text { Foi verificado que as reformas políticas não foram totalmente implementadas pelos burocratas de nível de rua; as agências são } \\
\text { precariamente alinhadas com as novas políticas; assistência técnica e informacional aos trabalhadores é incompleta e inconsistente. }\end{array}$ \\
\hline 1999 & Johnston \& Romzek & Kansas & $\begin{array}{l}\text { Entrevistas e } \\
\text { Documentos }\end{array}$ & $\begin{array}{c}\text { Agentes públicos e } \\
\text { agentes das entidades } \\
\text { privadas envolvidas no } \\
\text { contrato }\end{array}$ & $\begin{array}{l}\text { Falta de competição na escolha dos contratados. Contratados com pouca capacidade gerencial. Existência de complexidade dos serviços } \\
\text { prestados. Accountability, mensuração de desempenho e monitoramento contratual inadequados.Processo de contratualização possui } \\
\text { influências políticas. }\end{array}$ \\
\hline 1999 & Alexander et al. & Ohio & $\begin{array}{l}\text { Questionários e } \\
\text { grupos focais }\end{array}$ & $\begin{array}{l}\text { Entidades privadas sem } \\
\text { fins lucrativos }\end{array}$ & $\begin{array}{l}\text { Verificou-se: o desenvolvimento de uma estratégia de sobrevivência em virtude da dependência de recursos do governo;contratado com } \\
\text { pouca autonomia e autoridade no processo decisório de gestão; aumento da necessidade de transparênciafinanceirae programática; } \\
\text { necessidade de a missão e as características organizacionais serem profissionalizadas. }\end{array}$ \\
\hline 1999 & Beinecke \& DeFillippi & Massachusetts & Entrevistas & $\begin{array}{c}\text { Agentes públicos e } \\
\text { agentes das entidades } \\
\text { privadas envolvidas no } \\
\text { contrato }\end{array}$ & $\begin{array}{l}\text { A contratualização não substitui a necessidade de gestão pública dos recursos e do capital humano; dada a falta de capacidade } \\
\text { administrativa e competição, um modelo pode ser utilizado no gerenciamento dos contratos. }\end{array}$ \\
\hline 1999 & Chambre & $\begin{array}{l}\text { Cidade de Nova } \\
\text { Iorque }\end{array}$ & $\begin{array}{c}\text { Entrevistas, } \\
\text { Documentos e } \\
\text { Dados de arquivo }\end{array}$ & Eclético & $\begin{array}{l}\text { A epidemia de Aids aumentou a demanda por fornecedores de serviços complexos em um sistema que apresentava redundância de } \\
\text { serviços. }\end{array}$ \\
\hline 1999 & Sandfort & Michigan & $\begin{array}{l}\text { Entrevistas, } \\
\text { grupos focais, }\end{array}$ & $\begin{array}{l}\text { Organizações envolvidas } \\
\text { nas relações contratuais }\end{array}$ & $\begin{array}{l}\text { Colaboração entre os agentes públicos e as agências no nível de rua; estrutura organizacional e processos influenciando o nível e tipo de } \\
\text { colaboração; as barreiras entre as partes criou ineficiências, mensagens ambíguas e informações imprecisas. }\end{array}$ \\
\hline
\end{tabular}

continua (1/3) 
Continuação

\begin{tabular}{|c|c|c|c|c|c|}
\hline Ano & Autores & Objeto & Metodologia & Foco da pesquisa & Resultados encontrados \\
\hline 2003 & Slyke & $\begin{array}{l}\text { Cidade de Nova } \\
\text { Iorque }\end{array}$ & Entrevistas & $\begin{array}{l}\text { Gestores públicos e } \\
\text { gestores das entidades } \\
\text { privadas sem fins } \\
\text { lucrativos }\end{array}$ & $\begin{array}{l}\text { A contratualização é um ato muito mais político do que econômico. A falta de competição e de capacidade administrativa por parte dos } \\
\text { contratados é um dos maiores desafios quando o governo contrata.Contratos com metas divergentes da realidade política e burocrática } \\
\text { inibem a capacidade dos gestores públicos de mitigarem fraudes, desperdícios e abusos. }\end{array}$ \\
\hline 2004 & Brown \& Potoski & Columbus & $\begin{array}{l}\text { Entrevistas, } \\
\text { análise } \\
\text { documental e } \\
\text { dados de arquivo }\end{array}$ & $\begin{array}{l}\text { Gestores das entidades } \\
\text { privadas sem fins } \\
\text { lucrativos, autoridades } \\
\text { governamentais e chefe } \\
\text { da entidade reguladora da } \\
\text { política pública em } \\
\text { questão e seus contratos } \\
\end{array}$ & $\begin{array}{l}\text { Os gestores públicos seguem uma série de protocolos para obter informações, tanto para monitoramento e para análise de desempenho } \\
\text { dos contratados quanto para conhecer melhores práticas de contratação. Os gestores estimulam a competição implementando incentivos } \\
\text { e buscando possíveis interessados em contratar com o governo. Os gestores criam e mantêm redes efetivas que asseguram o bom } \\
\text { funcionamento dos contratos }\end{array}$ \\
\hline 2006 & Slyke & $\begin{array}{l}\text { Estado e Cidade } \\
\text { de Nova Iorque }\end{array}$ & Entrevistas & $\begin{array}{l}\text { Gestores públicos e de } \\
\text { entidades privadas sem } \\
\quad \text { fins lucrativos }\end{array}$ & $\begin{array}{l}\text { Os resultados sugerem que a confiança, a reputação e o monitoramento influenciam na maneira como o contrato é gerenciado; verificou- } \\
\text { sena contratualização de serviços sociais: tipo de serviço, falta de um mercado competitivo e restrições de capacidade gerencial } \\
\text { comprometem a execução dos contratos firmados. }\end{array}$ \\
\hline 2007 & Brown, Potoski \& Slyke & $\begin{array}{l}\text { Ohio e Nova } \\
\text { Iorque }\end{array}$ & $\begin{array}{c}\text { Análise } \\
\text { documental }\end{array}$ & $\begin{array}{l}\text { Contratos entre o setor } \\
\text { público com terceiros } \\
\text { para a coleta de lixo e } \\
\text { para prestação de serviços } \\
\text { sociais }\end{array}$ & $\begin{array}{l}\text { Os autores compararam dois tipos de contratos: um para coleta de lixo e outro para prestação de serviços sociais. A relação entre o nível } \\
\text { de completude dos contratos e o nível de confiança entre governo e contratado é aleatório. Conforme foi revelado pela análise documental, } \\
\text { a forma como os contratos são redigidos não é ótimo para todas as circunstâncias ao longo do tempo. No entanto, foi verificado que os } \\
\text { custos de monitoramento diminuem no longo prazo, quando o governo contrata uma parte que ele confia, isto é, que existe uma relação } \\
\text { construída ao longo do tempo. }\end{array}$ \\
\hline 2007 & Heinrich \& Choi & Winsconsin & $\begin{array}{c}\text { Análise } \\
\text { documental e } \\
\text { dados de arquivo }\end{array}$ & $\begin{array}{l}\text { Contratos, banco de dados } \\
\text { de seguro-desemprego, } \\
\text { memorandos, dados } \\
\text { administrativos }\end{array}$ & $\begin{array}{l}\text { Foram realizadas modificações racionais nas especificações contratuais e na mensuração de desempenho que melhoraram a eficiência e } \\
\text { efetividade do programa no tempo e as partes contratadas responderam a essas mudanças alocando esforços para alcançar as metas } \\
\text { pactuadas.As deficiências na gestão da política e dos contratos contribuíram para que alguns contratos falhassem ou tivessem um } \\
\text { desempenho aquém do esperado. }\end{array}$ \\
\hline 2008 & Amirkhanyan & $\begin{array}{l}50 \text { estados } \\
\text { americanos }\end{array}$ & $\begin{array}{l}\text { Entrevistas e } \\
\text { dados de arquivo }\end{array}$ & $\begin{array}{l}\text { Gestores públicos, de } \\
\text { entidades privadas sem } \\
\text { fins lucrativos e com fins } \\
\text { lucrativos }\end{array}$ & $\begin{array}{l}\text { O objetivo do estudo foi explorar a prevalência e os determinantes da colaboração no monitoramento dos contratos governamentais. Os } \\
\text { resultados sugerem que uma variedade de atividades colaborativas éempregada pelo setor público e seus contratados: os agentes públicos } \\
\text { solicitam inputs para avaliação de desempenho e os contratados desenvolvem e propõem novas mensurações de desempenho, além de } \\
\text { negociarem ativamente sobre os processos de monitoramento já existentes. Os determinantes da colaboração são mais frequentes em } \\
\text { contratantes de entidades privadas sem fins lucrativos ou de entidades com fins lucrativos que possuem expertise única e alta dependência } \\
\text { de recursos. Governos que possuem agentes com alta capacidade profissionais e dispostos a colaborar são mais propensos a solicitar e } \\
\text { incorporar as demandas dos contratados. }\end{array}$ \\
\hline 2008 & Gazley & Geórgia & $\begin{array}{l}\text { Questionários e } \\
\text { Entrevistas }\end{array}$ & $\begin{array}{l}\text { Representantes do } \\
\text { governo e das entidades } \\
\text { privadas sem fins } \\
\quad \text { lucrativos }\end{array}$ & $\begin{array}{l}\text { Os autores analisaram os aspectos informais da relação contratual entre governo e entidades privadas sem fins lucrativos. O estudo revelou } \\
\text { que a ligaçãa não contratual entre as entidades e o governo pode se dar de várias formas: estatutária, financeira etc. O estudo encontrou } \\
\text { menor evidência de relação colaborativa entre as entidades, uma vez que o compartilhamento do processo decisório entre entidades é } \\
\text { uma das principais características da colaboração. O estudo sugere que a relação de confiança não somente emerge dos arranjos formais } \\
\text { como podem substituí-los. }\end{array}$ \\
\hline 2008 & Johnston \& Romzek & Kansas & $\begin{array}{c}\text { Análise } \\
\text { documental e } \\
\text { dados de arquivo }\end{array}$ & $\begin{array}{l}\text { Contratos referentes à } \\
\text { entrega de produtos e } \\
\text { serviços de duas políticas } \\
\text { públicas sociais }\end{array}$ & $\begin{array}{l}\text { O objetivo do estudo foi verificar o impacto da estabilidade do sistema na implementação e gerenciamento dos contratos de prestação de } \\
\text { serviços de dois programas sociais. Os resultados demonstraram que há custos significantes na entrega de produtos e serviços. }\end{array}$ \\
\hline
\end{tabular}

continua (2/3) 
Ilustração 1: Pesquisas sobre contratos de serviços sociais

\begin{tabular}{|c|c|c|c|c|c|}
\hline Ano & Autores & Objeto & Metodologia & Foco da pesquisa & Resultados encontrados \\
\hline 2011 & Suárez & Califórnia & $\begin{array}{l}\text { Entrevistas e } \\
\text { Questionários }\end{array}$ & $\begin{array}{l}\text { Gestores das entidades } \\
\text { privadas sem fins } \\
\text { lucrativos }\end{array}$ & $\begin{array}{l}\text { O objetivo era verificar as estratégias gerenciais utilizadas pelas entidades privadas sem fins lucrativos para aumentarem a quantidade de } \\
\text { contratos ede recursos, com o governo local, estadual e federal. Os resultados demonstraram que o financiamento governamental em } \\
2000 \text { aumenta a probabilidade de financiamento em } 2004 \text {. Assim, os contratos governamentais são uma fonte estável de receita para essas } \\
\text { entidades. Ainda, os autores verificaram que colaboração e profissionalização apresentam efeitos significantes no financiamento } \\
\text { governamental. }\end{array}$ \\
\hline 2012 & Lecy \& Slyke & EUA & Dados de arquivo & $\begin{array}{l}\text { Entidades privadas sem } \\
\text { fins lucrativos e governo }\end{array}$ & $\begin{array}{l}\text { O objetivo do artigo é analisar a quantidade das entidades privadas sem fins lucrativos em um espaço geográfico (densidade), sob a ótica } \\
\text { de duas teorias: falha governamental e interdependência. Para isso, os autores analisaram uma base de dados que contém, entre outras } \\
\text { informações, as fontes de receitas dessas entidades. Os resultados revelaram que a densidade dessas entidades é maior em regióes em que } \\
\text { há mais repasse de recursos governamentais (por meio de subvenções e/ou contratos com o governo). }\end{array}$ \\
\hline 2012 & Witesman \& Fernandez & $\begin{array}{l}982 \text { governos } \\
\text { locais }\end{array}$ & $\begin{array}{l}\text { Entrevistas e } \\
\text { Questionários }\end{array}$ & $\begin{array}{l}\text { Gestores públicos de } \\
\text { governos locais e } \\
\text { fornecedores de serviços } \\
\text { de entidades com e sem } \\
\quad \text { fins lucrativos }\end{array}$ & $\begin{array}{l}\text { Os autores tinham como objetivo verificar a forma como os agentes públicos percebem, estruturam e gerenciam as relações contratuais } \\
\text { com entidades privadas com e sem fins lucrativos. Os resultados revelaram que os agentes públicos têm maior confiança nos serviços } \\
\text { prestados por entidades sem fins lucrativos do que em entidades com fins lucrativos. Ainda, os resultados revelaram que os agentes } \\
\text { públicos monitoram os contratos com entidades sem fins lucrativos menos frequentemente do que aqueles com entidades com fins } \\
\text { lucrativos., sugerindo que contratos com entidades sem fins lucrativos ajudam a reduzir os custos de administração e monitoramento. }\end{array}$ \\
\hline 2012 & Ashley \& Slyke & Geórgia & Dados de arquivo & $\begin{array}{l}\text { Repasse de recursos para } \\
\text { entidades privadas sem } \\
\quad \text { fins lucrativos }\end{array}$ & $\begin{array}{l}\text { O objetivo dos autores foi verificar se a taxa administrativa é um indicador de preço ou um indicador de qualidade nos repasses } \\
\text { governamentais. Para isso, os autores mesclaram informações de quatro agências governamentais no estado da Geórgia com dados de } \\
\text { repasses financeiros do governo central. Utilizando um modelo multinível, os resultados ainda permanecem inconclusivos no que tange } \\
\text { a verificar se é o custo ou a qualidade que explica os custos administrativos dos contratos de repasse de recursos. }\end{array}$ \\
\hline 2016 & Fine et al. & Nova Jersey & $\begin{array}{l}\text { Entrevista e } \\
\text { dados de arquivo }\end{array}$ & $\begin{array}{l}\text { Entrevistas com gestores } \\
\text { públicos e especialistas }\end{array}$ & $\begin{array}{l}\text { O objetivo do estudo foi verificar as práticas de accountability no monitoramento dos contratos de serviços sociais feitos pelo governo } \\
\text { de Nova Jersey. Os resultados revelaram uma falta de capacidade de supervisão em virtude da presença de gestores contratuais com } \\
\text { treinamento e capacidades inadequadas. Ainda, os autores verificaram falhas na supervisão, no desenho e nos custos contratuais sob a } \\
\text { ótica do framework institucional e constataram que, em virtude de ideologia ou ignorância, muito dos contratos são firmados com a } \\
\text { premissa de que a mera utilização de contratantes privados é suficiente para aumentar a eficiência. Fine et al. (2016) concluíram que os } \\
\text { contratos são frequentemente firmados por razões políticas e não por uma rigorosa análise custo-benefício. Dessa forma, o estudo } \\
\text { demonstra que tanto o agente quanto o principal esquivam-se das suas responsabilidades. }\end{array}$ \\
\hline 2016 & Lecy \& Thornton & EUA & Dados de arquivo & $\begin{array}{l}\text { Contratos de serviços } \\
\text { sociais }\end{array}$ & $\begin{array}{l}\text { O objetivo do artigo foi analisar o complexo relacionamento financeiro entre o governo e as entidades privadas sem fins lucrativos. Para } \\
\text { isso, os autores utilizaram uma ampla base de dados que contém informações sobre o repasse de milhões de dólares referentesa subvenções } \\
\text { e contratos. Uma limitação da pesquisa foi a ausência de identificação apropriada entre o recurso federal e da entidade beneficiada. }\end{array}$ \\
\hline 2016 & $\mathrm{Lu}$ & EUA & Dados de arquivo & $\begin{array}{l}\text { Dados do censo nacional } \\
\text { de contratação de serviços } \\
\text { humanos }\end{array}$ & $\begin{array}{l}\text { O objetivo dos autores foi verificar o impacto da diversidade social nos contratos de serviços públicos. Por meio de um modelo } \\
\text { multivariado, os autores encontraram que estados com maior grau de diversidade social possuem mais contratos para serviços sociais. }\end{array}$ \\
\hline 2017 & Boyer \& Kolpakov & EUA & $\begin{array}{l}\text { Entrevista e } \\
\text { dados de arquivo }\end{array}$ & $\begin{array}{l}\text { Entrevistas com gestores } \\
\text { de entidades privadas sem } \\
\quad \text { fins lucrativos }\end{array}$ & $\begin{array}{l}\text { O objetivo do artigo foi verificar a frequência das relações entre entes governamentais e entidades privadas sem fins lucrativos e assim } \\
\text { examinar as diferentes estruturas de parceria existente: foco no principal, agente e gestão compartilhada. Os resultados revelaram que } \\
\text { melhoria nos indicadores e aumento do repasse de recursos são as principais causas das parcerias firmadas. }\end{array}$ \\
\hline
\end{tabular}




\subsubsection{Transferências Voluntárias no Brasil}

Nesta seção, a finalidade é apresentar brevemente as perspectivas sob a ótica do Direito, da Ciência Política, da Economia, das Políticas Públicas e da Contabilidade e, assim, demonstrar o seu atual estado da arte das transferências voluntárias.

O debate sobre transferências intergovernamentais no Brasil apresenta uma infinidade de abordagens em virtude da pluralidade inerente ao tema (Conti\& Carvalho, 2001; Meyer, 2003; Salinas, 2008; Mendes, Miranda \& Cosio, 2008; Gomes, 2009; Ribeiro, 2010; Lofrano, 2010; Cataia, 2011; Dallaverde, 2015, Lima et al., 2017).

Dallaverde (2015) ressalta que na discussão das transferências governamentais importa a autonomia dos entes federados como uma das características básicas do federalismo, já que não é possível falar em autonomia sem garantia de recursos financeiros para sua concretização.

Dessa forma, a autora destaca que a repartição de competências prevista no texto constitucional tem por objetivo o alcance de uma única finalidade, o desenvolvimento do Estado, ainda que realizada entre os diversos níveis de governo. Portanto, os repasses entre os entes federados visam à redução do desequilíbrio fiscal vertical e das disparidades regionais, bem como à correção das externalidades e o aproveitamento da estrutura administrativa do entre descentralizado, conforme já destacou Gomes (2009).

Assim, citando o princípio da subsidiariedade, segundo o qual os entes devem atuar conforme suas competências, afastando possíveis ingerências do ente central, Dallaverde (2015) destaca que as transferências voluntárias são instrumentos que permitem as entidades menores executarem as competências que a própria Constituição lhe conferiu e ressalta que os recursos repassados se tornam subsidiários. Nessa linha, Gomes (2009) já havia ressaltado que a falta de previsibilidade e regularidade inerente ao seu repasse pode comprometer o planejamento local e defende o estabelecimento dos fundamentos econômicos de distribuição de recursos que podem auxiliar na solução de conflitos entre os entes federativos.

Ribeiro (2010), ao expor o modelo legal de transferências voluntárias, destacou três características: (i) formalismo processual, isto é, o extenso rol de documentos exigidos pela legislação para individualizar e especificar o objeto a ser conveniado, qualificar técnica e juridicamente o interessado, verificar adimplência tributária, fiscal e contratual etc.; (ii) personalismo dos pleitos, ou seja, o fato de os pleitos serem examinados individualmente, segundo a característica de cada contrato, o que pode aumentar a subjetividade da análise; e a 
(iii) descentralização tutelada, que se refere a uma duplicação de esforços, pois o ente beneficiário age em nome próprio, mas sob intenso monitoramento do órgão repassador, ao qual compete planejar, analisar, avaliar, fiscalizar, aprovar, rejeitar e até mesmo verificar a observância, por parte do beneficiado, dos princípios norteadores da administração pública, entre eles a legalidade, a impessoalidade, a moralidade, a publicidade e a eficiência.

O autor verificou que desde 1992 há relatórios tanto oriundos de Comissões Parlamentares de Inquérito (CPI/CPMI) quantode órgãos de controle (TCU e CGU), os quais destacaram a necessidade de um melhor controle e monitoramento das transferências voluntárias. Dessa maneira, Ribeiro (2010) classificou os problemas identificados nesses relatórios em (i) deficiências de controle dos órgãos repassadores, causa da maioria das irregularidades e (ii) irregularidade na execução do plano de trabalho.

Para o autor, as deficiências de controle dos órgãos repassadores não foram sanadas, porque, primeiro, analisar e fiscalizar tantos convênios e contratos de repasse (em 2010, mais de 24 mil arranjos anuais) exige estruturas de recursos humanos, materiais e tecnológicas não disponíveis na administração pública federal e, segundo, em virtude do fato de que, investir em tal estrutura não se revelou uma prioridade (análise de custo-benefício) do ponto de vista político e econômico.

Em relação à execução do plano de trabalho por parte dos entes federados, em especial, e sua capacidade de gerir essa espécie de recursos públicos, Ribeiro (2010) entende que

\footnotetext{
Insistir no raciocínio de falta de competência técnica ou institucional dos entes subnacionais equivaleria colocar em xeque não só as prestações de contas regularmente apresentadas aos seus respectivos órgãos de controle interno [...], mas a própria competência dessas instituições para execução das funções de controle e fiscalização a eles outorgadas pela Carta Magna (p. 162).
}

Assim, o autor reitera que o mapa das irregularidades encontradas nos relatórios dos órgãos de controle até 2010 revelou que a capacidade técnica e de gestão do governo central não parece ser tão superior à dos entes subnacionais como muitos insistem em afirmar, uma vez que a maioria das irregularidades estão vinculadas a problemas de controle e monitoramento por parte do repassador de recursos, no caso, os órgãos e entidades de administração indireta do governo central.

Nesse sentido, Lofrano (2010) entende que o Portal dos Convênios apresenta um avanço qualitativo na busca de transparência, impessoalidade e moralidade, constituindo uma ferramenta para auditoria e controle social, transformando o paradigma da análise estritamente 
política para um paradigma que contemple aspectos gerenciais, com foco no resultado final das políticas públicas.

Necessita-se, dessa maneira, de um exame profundo do impacto dessas transferências sobre os produtos oferecidos pelos entes, sobretudo os municípios, principalmente pelo fato que os critérios de repasse estão cada vez mais técnicos e não estritamente político-partidários, apesar de as transferências voluntárias ainda serem, do ponto de vista político, um instrumento de "alargamento de Poder da União sobre as municipalidades, principalmente naquelas que têm seus orçamentos no limite do comprometimento com a Lei de Responsabilidade Fiscal" (Cataia, 2011, p.12).

Contudo, mesmo com o aumento da capacidade de gestão propiciada pelo Portal dos Convênios, para D’Abadia (2015), as transferências voluntárias ainda apresentam uma série de problemas como mal planejamento, ineficiência na alocação de recursos, falta de prestação de contas e de condições técnicas de execução por parte dos entes contemplados com os recursos, bem como falta de uma fiscalização ineficaz da aplicação dos recursos, o que faz com que os objetivos dos programas públicos do governo central não sejam atingidos.

Dessa maneira, o autor sugere algumas iniciativas que poderiam "ajudar na solução dos vícios" existentes: (1) regulamentação das transferências voluntárias por meio de Lei Complementar, dando maior segurança jurídica e previsibilidade para que municípios e estados se programem melhor e para o longo prazo; (2) regulamentação do processo de repasse de recursos do governo federal, dando maior segurança jurídica aos Estados e aos Municípios, no âmbito de convênios e contratos de repasse firmados com a União; (3) regulamentação de critérios para permitir o melhor direcionamento dos recursos, visando atender de fato as necessidades locais, reduzindo o poder da União em definir onde os recursos serão aplicados, uma vez que está distante da realidade que se pretende alterar. Esses critérios estariam relacionados aos indicadores do Estado ou Município, por exemplo: PIB per capita, índices de saúde, educação e segurança e índices de dinamismo econômico (D’Abadia, 2015, p. 11).

Há, portanto, duas grandes visões sobre o papel das transferências voluntárias: (i) a visão de que essas transferências são essenciais para a sobrevivência financeira e estrutural dos entes federados e grande propulsora das políticas públicas em nível local e (ii) a de que essas transferências são moeda de troca política, muitas vezes vinculados a interesses contrários ao "interesse público" e, assim, um instrumento de controle da União sobre os demais entes federados. Essas características são intrínsecas a esses instrumentos de repasse, conforme 
demonstram as pesquisas empíricas realizadas sobre o tema e não podem ser analisados de maneira isolada, pois são faces desse mesmo objeto. As próximas seções contemplam as pesquisas empíricas sobre o tema já realizadas no Brasil.

\section{a) Ciência e Economia política}

Pires Júnior (2003) demonstrou que o poder executivo federal se utilizou das transferências voluntárias para obter maior governabilidade. $\mathrm{O}$ autor verificou que existe um distanciamento entre alocação e distribuição eficiente dos recursos. Apesar disso, defende que os contratos de repasse são um forte mecanismo estratégico que propicia controle institucional e pessoal e podem ser utilizados como mecanismo de recompensa para o gestor público cumprir seus dispositivos legais.

Em linha com Pires Júnior (2003), Arretche \& Rodden (2004) desenvolveram uma pesquisa com o objetivo de verificar como a distribuição de recursos fiscais relaciona-se com as estratégias eleitorais e legislativas dos governantes brasileiros. Em relação às transferências voluntárias, os autores verificaram que a sua média aumentou no ano eleitoral de 1998, indicando que elas são empregadas como um recurso de estratégia eleitoral. Ainda, verificaram que, à época, o chefe do Executivo premiou com transferências voluntárias os estados onde obteve apoio em 1994 e em 1998. Em relação aos membros do Legislativo, a pesquisa demonstrou que pertencer à coalizão do governo do presidente aumenta exponencialmente as chances de os parlamentares obterem recursos para os seus estados e municípios de origem.

Com base em evidências que atestam o caráter realocativo do federalismo fiscal brasileiro e no modelo que o enxerga como uma barganha constitucional, Amorim Neto \& Simonassi (2013) analisaram a relação entre a promoção do desenvolvimento subnacional e os objetivos políticos do governo central. Para isso, os autores utilizaram variáveis políticas e econômicas com a finalidade de verificar os determinantes das decisões de alocação dos recursos federais no Brasil, bem como a relevância dos dispositivos disciplinadores como a LRF.

Os resultados revelaram que os objetivos políticos preponderam sobre os critérios de equidade e existe uma manutenção das desigualdades regionais, uma vez que o nível de recursos parece ser definido muito mais pela força política do que por critérios de desigualdades entre as regiões e necessidade da população local (Amorim Neto \& Simonassi, 2013).

Na mesma linha, Bijos (2013) desenvolveu uma pesquisa com o objetivo de investigar os 
elementos determinantes das transferências voluntárias federais para os municípios do Estado de Minas Gerais entre 2007-2011, com foco nas características locais e na capacidade de representação política municipal (baseando-se na alocação de votos em deputados federais em 2006). Assim, buscou-se compreender em que medida os vínculos municipais com deputados federais e as características econômicas, sociais, institucionais e políticas locais influenciam o volume de recursos recebidos do governo central por meio das transferências voluntárias.

Os resultados corroboram com os encontrados por Amorim Neto \& Simonassi (2013) e mostraram que tanto o componente político quanto o sócio demográfico influenciam as transferências voluntárias para os municípios mineiros estudados. Bijos (2013) concluiu que a capacidade institucional dos municípios é uma variável importante para explicar o fluxo de transferências voluntárias da União, o que pode indicar que os mecanismos de controle e supervisão, bem como as iniciativas recentes de promoção de maior transparência das contas públicas para as transferências discricionárias acarretaram maior volume de transferências de recursos, em virtude da utilização de modo responsável e eficiente.

Souza (2013) realizou uma análise comparativa do desempenho dos diferentes estados na captação de transferências voluntárias entre o período de 2003 a 2011. Por meio da análise das diferenças entre transferências pactuadas e as efetivamente pagas, o autor verificou que há grandes variações no montante de recursos que são efetivamente pagos ano a ano, o que compromete a execução de uma série de políticas públicas federais, sobretudo naqueles estados em há uma dependência financeira das transferências voluntárias. O autor revela ainda que, em média, o governo só repassou efetivamente $50 \%$ dos valores pactuados aos convenentes, o que enseja discussões sobre o equilíbrio federativo na distribuição de recursos.

Baião (2013) avaliou o efeito das transferências da Uniãona equalização fiscal dos municípios, por meioda capacidade e da necessidade fiscal, considerando características regionais e populacionais desses entes. Para isso, o autor analisou tanto as transferências redistributivas quanto as devolutivas. Os resultados mostraram que, dentre as transferências existentes, as voluntárias foram as que menos interferiram na equalização fiscal. Segundo Baião (2013), esse resultado explica-se pelo fato de esse tipo de transferência não seguir nem critérios redistributivos e nem devolutivos, mas políticos, que muitas vezes não se relacionam com a capacidade técnica e fiscal dos municípios.

Moutinho (2016) mapeou o cenário nacional de descentralização das transferências voluntárias federais para os municípios brasileiros por meio de programáticas ministeriais e de emendas 
parlamentares individuais. Por meio da análise dos dados disponíveis no Portal da Câmara dos Deputados, Tribunal Superior Eleitoral e dos Convênios, o autor verificou que (i) as transferências voluntárias via emendas parlamentares são mais eficazes quando comparadas às não provenientes de emendas; (ii) os congressistas da base aliada do governo central têm mais chances de terem suas emendas efetivamente pagas; (iii) há uma concentração de recursos direcionados para a região sul do Brasil; (iv) os municípios que mais solicitaram recursos não necessariamente foram os que mais receberam recurso. Assim, de uma maneira geral, os resultados apontaram uma distribuição heterogênea de recursos entre os municípios do Brasil.

Soares \& Melo (2016) analisaram os convênios entre União e municípios no período de 1995 a 2010. O objetivo dos autores foi verificar os fatores que determinam a participação dos entes locais no total de recursos distribuídos sob três dimensões: político-partidária, redistributiva e técnica. Os resultados revelaram que (i) os prefeitos do partido do presidente ou da sua base aliada receberam mais recursos de transferências voluntárias do que os prefeitos de oposição e ainda que (ii) nos anos de eleições presidenciais são repassados mais recursos aos governos locais. No que concerne às dimensões redistributivas e técnicas, os resultados revelaram que (iii) os municípios com maior arrecadação tributária foram os mais beneficiados com os recursos das transferências voluntárias. Para os autores, apesar de esse resultado refletir as necessidades de infraestrutura urbana e a capacidade técnica dos grandes municípios, ele ressalta o caráter não redistributivo das transferências discricionárias.

\section{b) Gestão Pública}

$\operatorname{Trezza}^{8}$ (2007) verificou se os termos de parceria estão cumprindo sua finalidade de ser um mecanismo que aumenta a flexibilidade do poder público e ao mesmo tempogarante controle, transferência do fornecimento de serviços e implementação de políticas públicas. Os resultados mostraram que houve um crescimento discreto dos termos de parceria firmados no período analisado e que há, para esses instrumentos de transferência, um equilíbrio entre a flexibilidade de gestão e o controle social. Apesar disso, a autora destacou que muitas das potenciais vantagens da lei ainda não estavam sendo plenamente aproveitadas, provavelmente, pela insegurança dos gestores em utilizar um novo instrumento e pela estrutura de funcionamento e cultura dos órgãos.

\footnotetext{
${ }^{8} \mathrm{O}$ trabalho não foi consultado na íntegra.
} 
Moutinho, Kniess \& Maccari (2013) identificaram como as práticas de gerenciamento de projetos influenciam o processo de transferências voluntárias de recursos em munícipios de médio porte no Brasil. Por meio de um estudo de caso em um município localizado no estado do Rio de Janeiro, os autores verificaram um elevado grau de heterogeneidade entre as secretarias municipais no que concerne à prática de gerenciamento de projetos. No entanto, para o município analisado, os autores constataram que as técnicas e ferramentas de gerenciamento são indutoras do sucesso dos projetos e promovem mudanças para uma cultura voltada a resultados.

Ainda analisando a esfera municipal e sob a ótica do gestor municipal, Ignarra (2014) mapeou atores e processos e propôs uma ferramenta de controle e monitoramento de transferências voluntárias na esfera municipal. Para isso, foi realizada análise documental e entrevistas semiestruturadas com gestores de78 municípios do estado do Rio de Janeiro. As análises realizadas permitiram identificar as principais dificuldades dos municípios para captar recursos de transferências voluntárias: (i) irregularidades relacionadas ao levantamento de informações; (ii) carência de gestores e técnicos capacitados no âmbito municipal; (iii) falta de integração dos órgãos municipais; e (iv) dificuldade de utilização dos recursos oriundos dos convênios em virtude do grau de exigência do governo central no que tange à execução e à prestação de contas. Baseado nisso, a pesquisadora desenvolveu uma ferramenta simplificada contemplando 8 grupos de informaçõescom a finalidade de auxiliar no planejamento da execução e prestação de contas em nível local.

Goulart (2015) desenvolveu uma pesquisa com o objetivo de verificar a eficiência relativa na execução das transferências voluntárias para os municípios mineiros, tendo por base dados socioeconômicos e de desempenho na execução das transferências. As variáveis analisadas foram: população, quantidade de funcionários, despesas com pessoal, valor das transferências voluntárias, percentual de realização das transferências voluntárias e de contratos concluídos e tempo médio de execução das transferências.

Para isso, os dados de 16 municípios mineiros foram obtidos por meio da Caixa Econômica Federal, da Secretaria do Tesouro Nacional e do IBGE no período de 2005 a 2009. Utilizando análise envoltória de dados (DEA), os resultados revelaram a quantidade de funcionários e o valor das despesas de pessoal podem impactar a eficiência da execução das transferências voluntárias para os municípios analisados (Goulart, 2015).

Lima et al. (2017) analisaram o atual estágio dos processos de controle e monitoramento dos 
projetos objeto de transferências voluntárias na Secretaria de Estado de Planejamento (Seplag) do estado do Alagoas e propuseram uma ferramenta de gestão para que o estado melhore seus processos de gestão e aumente, assim, o impacto de suas políticas públicas. Apesar de não terem evidenciado no artigo as principais fragilidades encontradas na Seplag, os autores destacaram a necessidade de uma gestão individualizada de cada projeto de forma a aumentar as suas chances de sucesso.

\section{c) Jurídica}

Salinas (2008) realizou um estudo de caso em se buscou avaliar os atos normativos de acordo com os efeitos que produzem na sociedade (avaliação legislativa) sobre as normas que disciplinam as transferências voluntárias de recursos públicos a entidades pertencentes ao terceiro setor. No caso da referida pesquisa, a avaliação se deu sob a perspectiva do controle da destinação dos recursos.

Por meio da análise documental de relatórios do Tribunal de Contas da União (TCU) e dos resultados da pesquisa de Trezza (2007), bem como por meio de entrevistas semiestruturadas com gestores de entidades privadas sem fins lucrativos sediadas em São Paulo, Salinas (2008) concluiu que os desafios impulsionadores da formulação e reformulação da legislação refletiram um desequilíbrio de interesses entre o setor público e o setor privado sem fins lucrativos.

Isso significa que os interesses do setor público foram contemplados, e os do setor privado negligenciados, o que fez com que se desenvolvesse resistência ao cumprimento da legislação, aumentando a chance de os efeitos esperados pelo legislador não serem produzidos. A autora concluiu que a legislação analisada estabeleceu uma série de obrigações aos órgãos responsáveis por sua implementação sem, no entanto, preocupar-se com a capacidade deles em executá-las.

Dallaverde (2015) analisou as transferências voluntárias sob uma ótica eminentemente jurídica, aprofundando a análise das transferências voluntárias, sua natureza, mecanismos, finalidades e inconsistências. O estudo realizado por ela aprofundou a discussão jurídica e apontou uma série de fragilidades ligada à gestão e ao controle, as quais destacam-se: a) ausência de critérios objetivos de definição das transferências voluntárias, efetuada por exclusão; b) ausência de padronização e fornecimento de elementos que possam uniformizar os programas em todos os 
instrumentos de busca; c) ausência de precisão dos dados representativos das transferências voluntárias; d) ausência de dados relativos à origem das transferências voluntárias; e) ausência de dados específicos relativos às transferências voluntárias. Para cada uma das fragilidades encontradas, a autora sugeriu melhorias, tais como a necessidade de uniformização de critérios de classificação de receitas e despesas e de distribuição das transferências e divulgação de dados sistematizados em decorrência de emendas parlamentares, por exemplo.

Adicionalmente, a autora destaca a importância da publicação dos dados relativos às transferências voluntárias por ente federado, com o objetivo de aumentar a transparência e evidenciar a realidade dos entes federados e o grau de atendimento das necessidades da população, haja vista que essa análise impacta diretamente o modelo de federalismo existente em nosso paíse,principalmente, a autonomia dos entes federados (Dallaverde, 2015).

Dallaverde (2015) discorre ainda sobre os aspectos jurídicos relacionados à naturezadas transferências voluntárias. Em relação aos aspectos políticos, a autora levanta a hipótese de que "[...] determinada transferência pode ter sido efetivada levando-se em conta critérios objetivos de melhor distribuição de recursos públicos, com foco no desenvolvimento de regiões menos favorecidas e, paralelamente, acarretar benefícios eleitorais" (p. 349).

No entanto, destaca que não há consenso doutrinário sobre a intenção do legislador brasileiro e afirma que a atuação parlamentar em matéria orçamentária busca efetivamente beneficiar os municípios da base eleitoral parlamentar, visto que essa prática não é vedada pela legislação.

No que se refere às feições técnicas, Dallaverde (2015) defende uma atenção maior aos municípios e estados que não dispõem de condições financeiras adequadas.Por fim, a autora sustenta a ideia de que o foco da discussão deve estar voltado aos resultados e não propriamente à legalidade, buscando o atendimento dos objetivos primordiais das transferências voluntárias.

A Ilustração 2 resume as características e resultados dos principais trabalhos empíricos sobre transferências voluntárias: 
Ilustração 2: Resumo das pesquisas realizadas sobre transferências voluntárias

\begin{tabular}{|c|c|c|c|c|}
\hline Ano & Autor & Área principal & Foco da análise & Principais resultados \\
\hline 2003 & Meyer & $\begin{array}{l}\text { Ciência e Economia } \\
\text { Política }\end{array}$ & Nacional & Distanciamento entre alocação de recurso e distribuição de recursos. Transferência como instrumento político de governabilidade. \\
\hline 2004 & Arretche \& Rodden & $\begin{array}{l}\text { Ciência e Economia } \\
\text { Política }\end{array}$ & Nacional & Transferência como instrumento político de governabilidade. \\
\hline 2007 & Trezza & Gestão Pública & Nacional & Equilíbrio entre flexibilidade de gestão e controle no uso dos instrumentos de transferências voluntárias. \\
\hline 2008 & Salinas & Jurídico & $\begin{array}{l}\text { Entidades privadas sem fins } \\
\text { lucrativos }\end{array}$ & $\begin{array}{l}\text { Resistência ao cumprimento da legislação por parte das entidades privadas sem fins lucrativos. A legislação estabeleceu uma série de } \\
\text { obrigações aos órgãos responsáveis pelo controle e monitoramento das transferências sem avaliar a sua capacidade de executá-las. }\end{array}$ \\
\hline 2013 & Amorim Neto \& Simonassi & $\begin{array}{l}\text { Ciência e Economia } \\
\text { Política }\end{array}$ & Nacional & Transferência como instrumento político de governabilidade. \\
\hline 2013 & Bijos & $\begin{array}{l}\text { Ciência e Economia } \\
\quad \text { Política }\end{array}$ & Município & $\begin{array}{l}\text { Transferência como instrumento político de governabilidade. Capacidade institucional do município influencia na quantidade de } \\
\text { transferências recebidas. }\end{array}$ \\
\hline 2013 & Souza & $\begin{array}{l}\text { Ciência e Economia } \\
\text { Política }\end{array}$ & Estado & Falta de regularidade dos repasses e contingenciamento compromete a execução dos convênios e equilíbrio federativo. \\
\hline 2013 & Baião & $\begin{array}{l}\text { Ciência e Economia } \\
\quad \text { Política }\end{array}$ & Município & Transferência como instrumento político de governabilidade \\
\hline 2013 & $\begin{array}{l}\text { Moutinho, Kniess \& } \\
\text { Maccari }\end{array}$ & Gestão Pública & Município & $\begin{array}{l}\text { Há divergências na prática de gerenciamento de projetos entre as secretarias municipais estudadas. Uso de técnicas e ferramentas de } \\
\text { gerenciamento de projetos estão relacionadas ao sucesso dos projetos de transferências nas secretarias que as utilizam. }\end{array}$ \\
\hline 2014 & Ignarra (2014) & Gestão Pública & Município & $\begin{array}{l}\text { Há heterogeneidade na prática de gerenciamento de projetos entre as secretarias municipais estudadas. Carência de gestores e técnicos } \\
\text { capacitados no âmbito municipal.Existência de irregularidades relacionadas ao levantamento de informações relacionadas às } \\
\text { transferências voluntárias }\end{array}$ \\
\hline 2015 & Goulart (2015) & Gestão Pública & Município & $\begin{array}{l}\text { Quantidade de funcionários e o valor das despesas de pessoal parecem impactar a eficiência da execução das transferências voluntárias } \\
\text { nos municípios estudados. }\end{array}$ \\
\hline 2015 & Dallaverde (2015) & Jurídico & Nacional & $\begin{array}{l}\text { Ausência de critérios objetivos de definição das transferências voluntárias, ausência de padronização dos elementos que possam } \\
\text { uniformizar os programas em todos os instrumentos de busca, ausência de precisão dos dados representativos das transferências } \\
\text { voluntárias. Transferência como instrumento político de governabilidade. Necessidade de análise do impacto das transferências na } \\
\text { execução das políticas públicas em nível local, conforme prevê o modelo de federalismo existente no país. }\end{array}$ \\
\hline 2016 & Moutinho (2016) & $\begin{array}{l}\text { Ciência e Economia } \\
\text { Política }\end{array}$ & Município & Distanciamento entre alocação de recurso e distribuição de recursos. Transferência como instrumento político de governabilidade \\
\hline 2016 & Soares \& Melo (2016) & $\begin{array}{l}\text { Ciência e Economia } \\
\text { Política }\end{array}$ & Município & Distanciamento entre alocação de recurso e distribuição de recursos. Transferência como instrumento político de governabilidade \\
\hline 2017 & Lima et al. (2017) & Gestão Pública & Estado & $\begin{array}{l}\text { Uso de técnicas e ferramentas de gerenciamento de projetos estão relacionadas ao sucesso do controle e monitoramento dos projetos } \\
\text { de transferências. }\end{array}$ \\
\hline
\end{tabular}


Sobre os resultados dos trabalhos elencados na Ilustração 2, é possível verificar alguns indícios de similaridade:

I. As transferências voluntárias são um instrumento político de coalizão política (governabilidade), e isso pode ser verificado tanto nas pesquisas em que o foco é a ciência e a economia política quanto nas pesquisas cujo foco é jurídico e de gestão;

II. Há um distanciamento entre alocação e distribuição de recursos. Ou seja, não necessariamente o ente que mais necessita é o ente que mais recebe recursos oriundos desse tipo de transferência, e as causas prováveis variam entre a coalizão política e capacidade técnica e institucional dos entes;

III. Os municípios são os entes mais dependentes das transferências voluntárias para a implementação dos programas públicos;

IV. Há uma expectativa, tanto dos pesquisadores quanto dos técnicos governamentais de que os instrumentos de transferências voluntárias considerem cada vez mais a necessidade local da população e a capacidade técnica das partes interessadas como justificativa para a celebração desses instrumentos.

Esta tese fundamenta-se em teorias das organizações, mais especificamente na relação entre TCE e TA. Nesse sentido, tanto a descrição do objeto quanto as análises serão realizadas sob essa perspectiva. Salienta-se, mais uma vez, que apesar da fundamentação teórica escolhida, não se pretende ignorar as outras perspectivas vinculadas ao tema, dada a sua pluralidade.

Os aspectos legais e normativos das transferências voluntárias são apresentados no Apêndice A. 


\subsection{Políticas Públicas de Emprego e de Economia Solidária}

No âmbito do setor público federal, o Ministério do Trabalho e Emprego (MTE) é o órgão da administração direta que tem como responsabilidade estabelecer: (i) política e diretrizes para a geração de emprego e renda e de apoio ao trabalhador; (ii) política e diretrizes para a modernização das relações do trabalho; (iii) fiscalização do trabalho, inclusive do trabalho portuário, e aplicação das sanções previstas em normas legais ou coletivas; (iv) política salarial; (v) formação e desenvolvimento profissional; (vi) segurança e saúde no trabalho; (vii) política de imigração; e (viii) cooperativismo e associativismo urbanos (Redação dada pelo Decreto 8.894 de 2016).

Por ser o órgão responsável pela matéria de emprego e renda no Brasil, o MTE desenvolve, executa e monitora uma série de políticas públicas relacionados ao tema. Para isso, suas ações são realizadas considerando a estrutura organizacional demonstrada na Ilustração 3 (ilustração baseada no Decreto 8.894 de 2016). 
Ilustração 3: Organograma MTE (simplificação baseada no Decreto 8.894/2016)

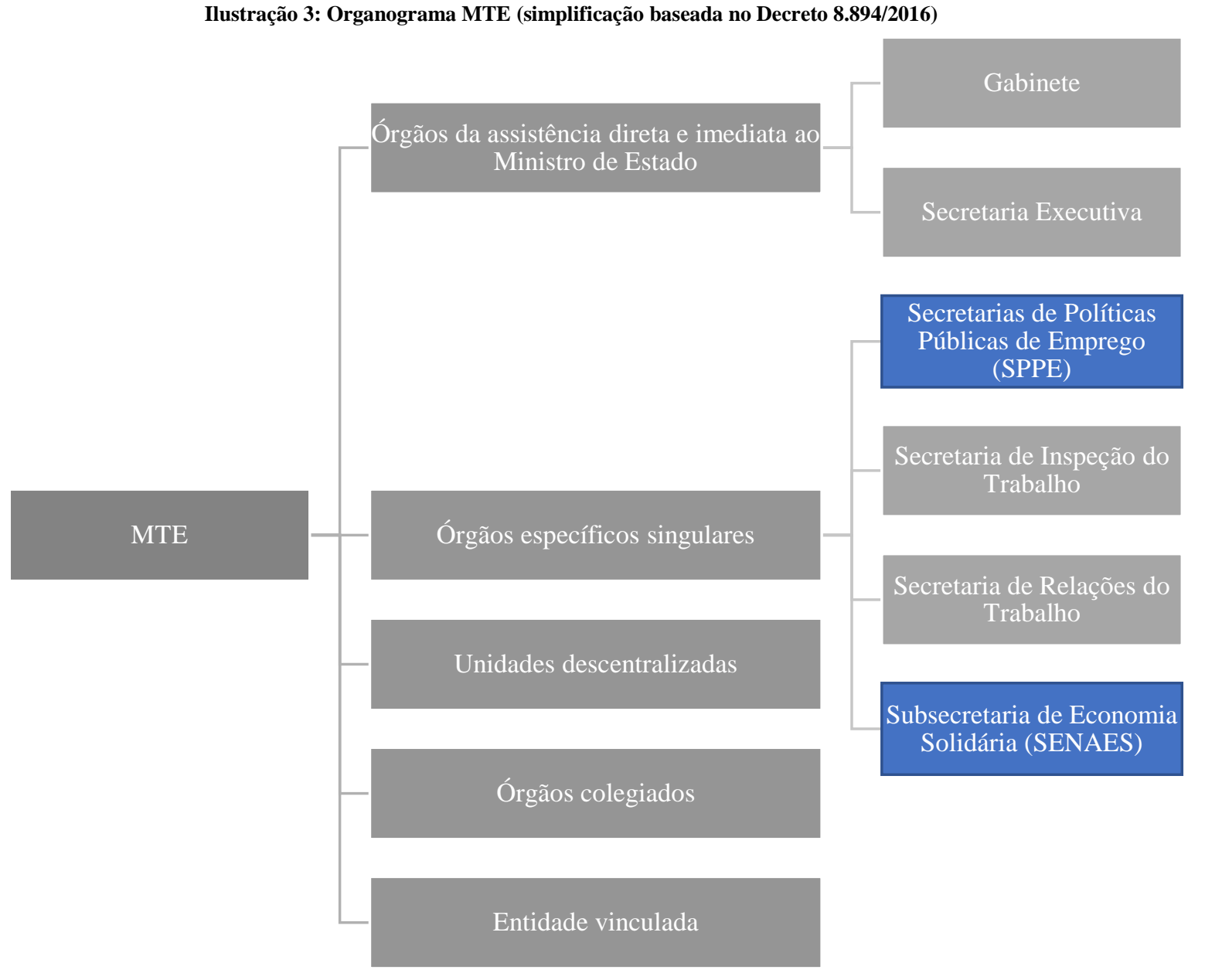


Grande parte dos programas públicos de emprego e de economia solidária no Brasil é executada mediante a celebração de instrumentos de transferências voluntárias, sobretudo os convênios do governo central com as administrações públicas estaduais (estado e distrito federal) e municipais (município), organizações da sociedade civil (entidades privadas sem fins lucrativos) e outras, a depender do programa e objetivo públicos.

Nesse sentido, o Decreto 8.894/2016 dispõe que compete a Secretaria de Políticas Públicas de Emprego (SPPE): (i) formular e propor políticas públicas de trabalho, emprego, renda, salário e de empregabilidade, como qualificação profissional, aprendizagem e estágio; (ii) planejar, controlar e avaliar os programas relacionados com a geração de emprego e renda, o seguro-desemprego, o apoio ao trabalhador desempregado, o abono salarial, a formação e o desenvolvimento profissional para o mercado de trabalho; (iii) planejar e coordenar as atividades relacionadas com o Sistema Nacional de Emprego quanto às ações integradas de orientação, recolocação, qualificação profissional e habilitação ao seguro-desemprego; (iv) planejar, coordenar, monitorar e avaliar as ações de estímulo ao primeiro emprego e de preservação do emprego; (v) acompanhar o cumprimento, em âmbito nacional, dos acordos e das convenções ratificados pelo Governo brasileiro junto a organismos internacionais, em especial à Organização Internacional do Trabalho - OIT, nos assuntos de sua área de competência; (vi) promover estudos da legislação trabalhista e da correlata, no âmbito de sua competência, e propor o seu aperfeiçoamento; (vii) supervisionar e avaliar as parcerias da Secretaria com outros órgãos do Governo central e com órgãos dos governos estaduais, distrital e municipais; (viii) promover o desenvolvimento da Rede Observatórios do Trabalho; e (ix)editar normas no âmbito de sua área de competência (Redação dada pelo Decreto 8.894 de 2016).

À Subsecretaria de Economia Solidária (Senaes) cabe: (i) propor medidas que incentivem o desenvolvimento da economia solidária, o fomento e o fortalecimento dos empreendimentos econômicos solidários e das suas redes de cooperação; (ii) promover pesquisas e estudos que contribuam para a produção e a disseminação de conhecimentos e tecnologias apropriadas ao desenvolvimento das iniciativas de economia solidária; (iii) coordenar, orientar e apoiar tecnicamente as atividades do Conselho Nacional de Economia Solidária; (iv) estimular a criação, a manutenção e a ampliação de oportunidades de trabalho e de acesso à renda, por meio de empreendimentos autogestionados, organizados de forma coletiva e participativa; (v) estimular as relações sociais de produção, distribuição e consumo baseadas na cooperação, na solidariedade, na satisfação e na valorização dos seres humanos e do meio ambiente; (vi) 
contribuir com as políticas de microfinanças, de maneira a estimular as finanças solidárias, o cooperativismo de crédito e outras formas de organização desse setor; (vii) coordenar a articulação e o desenvolvimento de parcerias com organizações governamentais, organizações da sociedade civil, entidades de classe, universidades e outras instituições para o desenvolvimento de programas e ações de apoio e fomento à economia solidária; (viii) promover a expansão dos empreendimentos solidários, mediante a abertura de canais de comercialização e a divulgação dos conceitos de comércio justo e solidário e do consumo ético e responsável; (ix) promover a articulação de políticas de financiamento e o desenvolvimento de linhas de crédito que sejam mais adequadas e viabilizem a criação de novos empreendimentos, o desenvolvimento e a consolidação dos já existentes; (x) fomentar iniciativas de assessoramento técnico e de gestão para a viabilidade dos empreendimentos econômicos solidários; (xi) promover ações de educação, formação e qualificação técnica para o desenvolvimento da economia solidária; (xii) promover campanhas e eventos públicos que tenham por objetivo a divulgação e a promoção da economia solidária; (xiii) promover estudos, emitir manifestações técnicas e elaborar proposições legislativas que visem ao reconhecimento dos empreendimentos econômicos solidários para acesso às políticas públicas, ao tratamento tributário adequado e ao fortalecimento institucional das políticas públicas de economia solidária; e (xiv) apoiar iniciativas das instituições de ensino superior com vistas à criação de campo acadêmico e científico da economia solidária por meio do fomento às incubadoras tecnológicas de empreendimentos econômicos solidários (Redação dada pelo Decreto 8.894 de 2016).

Em síntese, dadas as competências de cada uma das secretarias (eventualmente no texto será utilizado o termo secretaria para subsecretaria de economia solidária), a Ilustração 4 evidencia as informações pertinentes aos programas, ações, projetos e atividades implementadas por secretaria: 


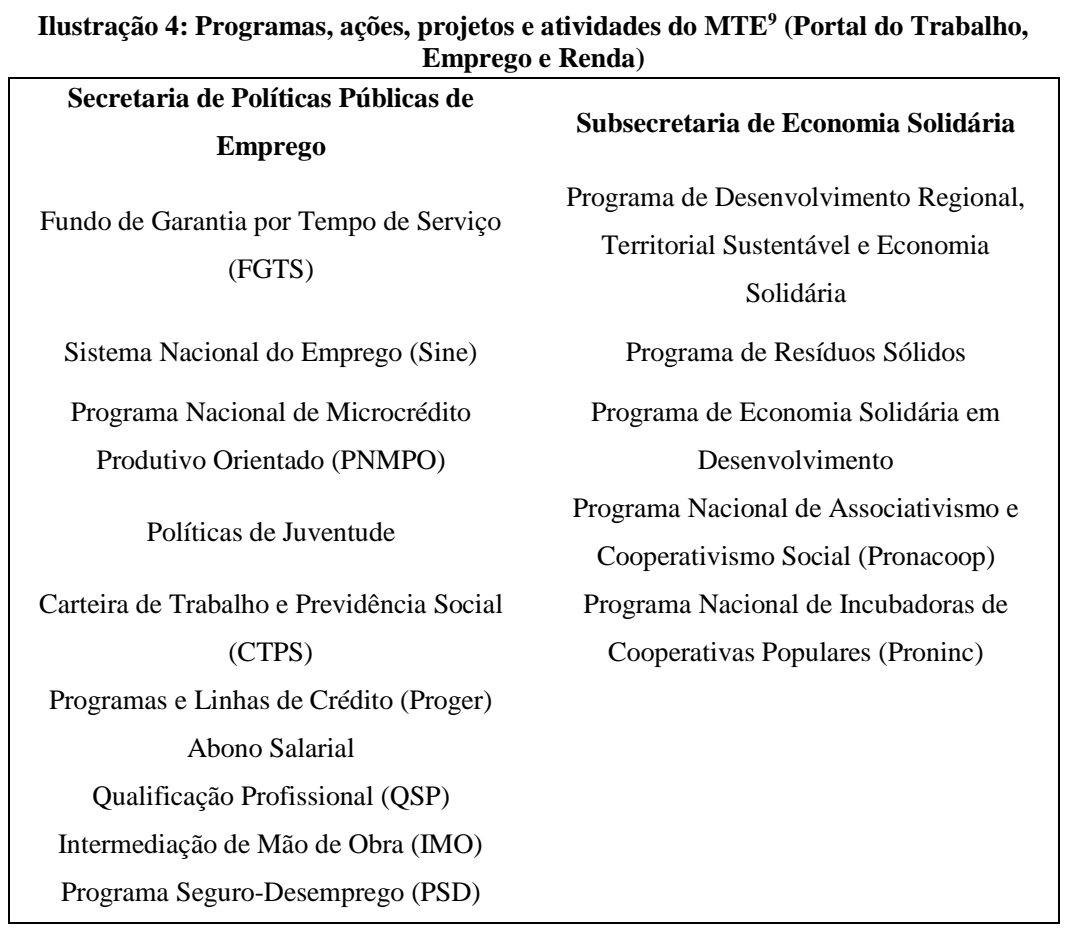

De uma maneira geral, há bastante sinergia entre os programas e ações desenvolvidos no âmbito da SPPE e da Senaes.

a) Relação entre secretarias, transferências voluntárias e políticas públicas: Secretaria de Política Públicas de Emprego (SPPE)

Os programas, ações e atividades desempenhadas pela SPPE são integradas pelo Sistema Nacional de Emprego (Sine) que, apesar de ter sido criado em 1975 com a finalidade principal de intermediação de mão de obra, teve sua finalidade ampliada a partir da criação do Programa Seguro-Desemprego (PSD), no artigo 239 da Constituição Federal de 1988, regulado pela Lei no 7.998 de 1990 .

A partir da criação do Programa do Seguro-Desemprego, o Sine passou a ser a rede de atendimento em que as ações desse Programa são executadas de forma integrada, a excetuar o pagamento propriamente dito do benefício do seguro-desemprego e fundo de garantia por tempo de serviço, que será realizado pela Caixa Econômica Federal (CEF). Por esse motivo, o Programa do Seguro-Desemprego, no âmbito do Sine, significa as ações desse Programa executadas nos postos de atendimento do Sine.

\footnotetext{
${ }^{9}$ Informações disponibilizadas pelo Portal do Trabalho e Emprego por meio do endereço: http://acesso.mte.gov.br/portal-mte/acesso-a-informacao/acoes-e-programas/. Acesso em: 10 ago. 2017.
} 
Assim, A Lei $n^{\circ} 8.019$ de 1990, que altera a Lei $n^{\circ} 7.998$ de 1990, estabelece que as ações do PSD serão executadas no Sine, prioritariamente pelos convênios, em articulação com os estados e municípios, mencionando o princípio da descentralização. Dessa maneira, as atividades executadas no âmbito do Sine são, principalmente: Seguro-Desemprego, Intermediação de Mão de Obra e apoio ao Programa de Geração de Emprego e Renda.

Essas atividades elencadas, para serem desenvolvidas na esfera do Sine, pela Lei $\mathrm{n}^{\circ} 8.019$ de 1990, contempla, direta e indiretamente, todos os programas, ações, projetos e atividades atribuídos à Secretaria de Política Públicas de Emprego (SPPE) pelo Decreto 8.894 de 2016 e sumarizados na Ilustração 7. Portanto, o Sine é os lócus físico prioritário das políticas de emprego e renda desenvolvidas pela SPPE.

A Avaliação Externa do Programa-Seguro Desemprego no Brasil (Marinho et al., 2010) evidenciou que o maior desafio do Sine está em integralizar a infinidade de suas metas tendo em vista os distintos programas que lhe são subordinados. Os resultados da avaliação externa do PSD revelaram que os Sines deveriam estar estruturadas em redes informatizadas, em todas as agências e postos de atendimento e com recursos financeiros adequados para desempenhar suas funções.

A rede de atendimento do Sine é constituída por aproximadamente 1.600 (mil e seiscentos) postos atualmente, localizados em todos os entes da federação, considerando tanto os postos localizados nas capitais quanto os localizados no interior ${ }^{10}$.

Baseado na Avaliação Externa do Programa-Seguro Desemprego no Brasil (Marinho et al., 2010), o MTE publicou um estudo intitulado Estudo de Custos no Sistema Nacional do Emprego (Silva et al., 2012) que teve como objetivo desenvolver uma metodologia que permitisse obter os custos de manutenção da rede, apoiados em critérios contábeis, e estabelecer parâmetros para análise de propostas de convênios na esfera do Sine.

Salienta-se que o intuito era estabelecer uma metodologia que pudesse ser formalizada futuramente em um instrumento normativo e que funcionasse como parâmetro para a distribuição dos recursos disponíveis aos convenentes, de forma a racionalizar a distribuição, melhorar a qualidade do gasto público, a transparência pública e o controle social.

\footnotetext{
${ }^{10}$ Segundo informações da Base de Gestão do MTE, os postos do Sine alcançam 115 milhões de pessoas, o que corresponde $63 \%$ da população brasileira considerando o último censo revelado pelo IBGE (Silva et al., 2012)
} 
Vale destacar que, até o ano de 2013, os critérios de distribuição do recurso federal para os convenentes eram estabelecidos pelas Resoluções Codefat $n^{\circ} 563 / 2007, n^{\circ}$ 644/2010 e $n^{\circ}$ 702/2012, que de uma maneira geral estabeleciam somente os limites máximos a serem repassados para estados, municípios e entidades privadas sem fins lucrativos, dando discricionariedade ao administrador público para a distribuição dos recursos.

Nesse sentido, a Resolução $n^{\circ} 721 / 2013$ (alterada em partes pelas Resoluções $n^{\circ} 722 / 2013$ e $n^{\circ}$ 728/2014) trouxe uma importante inovação no que tange à distribuição dos recursos entre os convênios firmados com a SPPE. Essa resolução, produto do modelo e da metodologia desenvolvidos no Estudo de Custos no Sistema Nacional do Emprego, estabeleceu que, a partir de sua publicação, os critérios de distribuição dos recursos serão baseados nos critérios contábeis de custo de manutenção da rede de atendimento para o Programa Seguro-Desemprego no âmbito do Sistema Nacional de Emprego - Sine, de forma a garantir a transparência no repasse.

Portanto, a partir da Resolução $\mathrm{n}^{\circ} 721 / 2013$, os custos dos serviços prestados no âmbito do Programa foram calculados, anualmente, com base no Time-Driven Activity-Based Costing $(\mathrm{TDABC})^{11}$ que considera o princípio contábil da competência. Essa forma de cálculo considera o custo de se prestar o serviço público em cada um dos postos de atendimento ao trabalhador, independentemente da origem do recurso, se federal, estadual ou municipal, o que permite ao gestor racionalizar o repasse de recurso para a manutenção da rede e proposição de convênios, tentando aproximar a distribuição do recurso da real necessidade de cada posto de atendimento visando aprimorar a prestação de serviço público, a transparência e controle das transferências voluntárias.

Essa mudança foi importante, uma vez que o Tribunal de Contas da União (TCU), por meio do Acordão 1.687/2009, referente ao relatório de auditoria operacional e financeira das transferências voluntárias do MTE, destacou a insuficiência de critérios práticos, fixados em normativos, para a seleção das unidades beneficiárias de recursos objeto de transferências voluntárias em diversos programas geridos pelo MTE, inclusive no âmbito do Sine. Nesse sentido, o referido acordão traz como um dos resultados do relatório de auditoria: "não existem

\footnotetext{
11 Esse método é baseado no Custeio Baseado em Atividades (ABC) tradicional. Representa uma opção simplificada de cálculo de custo de produtos e serviços porque utiliza como direcionador de custo para todas as atividades o seu tempo de execução (Kaplan \& Anderson, 2007).
} 
critérios objetivos que embasem a escolha definitiva dos proponentes do convênio, impessoal e imparcialmente, sem privilégios de qualquer ordem (p. 6).”

b) Relação entre secretarias, transferências voluntárias e políticas públicas: Subsecretaria de Economia Solidária (Senaes)

O MTE atua, para além das iniciativas de emprego e de proteção dos trabalhadores assalariados, implementando políticas que incluam as demais formas de organização do mundo do trabalho e proporcionem a extensão dos direitos ao conjunto dos trabalhadores por meio da Secretaria de Economia Solidária (Senaes).

Conforme descreve o Conselho Nacional de Economia Solidária (Cnaes), no Plano Nacional de Economia Solidária (Pnaes):

Economia solidária envolve formas de organização econômica de produção, de prestação de serviços, de comercialização, de finanças e de consumo baseadas no trabalho associado, na autogestão, na propriedade coletiva dos meios de produção, na cooperação e na solidariedade (p. 5).

O Sistema de Informação em Economia Solidária (Sies) tem como finalidade identificar e caracterizar os empreendimentos econômicos solidários (EES) e as entidade de apoio, assessoria e fomento à economia solidária (EAF). Dessa maneira, o objetivo do Sies é (i) constituir uma base nacional de informações em ES; (ii) fortalecer e integrar os EES por meio do cadastro, redes, catálogos de produtos e redes de comercialização; (iii) favorecer a visibilidade da ES, fortalecendo processos organizativos, de apoio e adesão da sociedade; subsidiar processos públicos (iv) de reconhecimento e certificação das iniciativas de ES; e (v) de formulação de políticas públicas e elaboração de um marco jurídico para a economia solidária.

De forma semelhante ao Sine, os programas, ações e projetos desempenhados pela Senaes são integradas por meio das informações disponíveis no Sies e são desenvolvidos meio de ações diretas ou por meio de cooperação e convênios com outros órgãos governamentais federais, estaduais e municipais e com organizações da sociedade civil que atuam com a economia 
solidária. Conforme informações obtidas por meio do Atlas Digital da Economia Solidária no Sies12, atualmente existem 19.708 (dezenove mil setecentos e oito) EES no Brasil.

Na fase qualitativa da Avaliação das Políticas Públicas de Economia Solidária (Araújo, 2005), os avaliadores realizaram estudo de caso nos municípios de São André, São Bernardo, Mauá e São Carlos, no Estado da Bahia e municípios de Aracaju e Recife. Os resultados encontrados pelos avaliadores foram: (i) existem projetos e ações, mas esses não possuem uma diretriz geral que os oriente e há uma (ii) frágil institucionalização das políticas de economia solidária. Assim, os avaliadores extraíram três características dos estudos de caso realizados: (i) a parceria com a sociedade civil é condição essencial para efetividade; (ii) possuem forte vocação indutiva; e (iii) apontam um horizonte de organização da própria sociedade, numa perspectiva de construção de novas institucionalidades ou marcos regulatórios.

A Avaliação das Políticas Públicas de Economia Solidária (Araújo, 2005) em sua fase quantitativa evidenciou as principais diferenças na implementação de políticas de geração de trabalho e renda e as políticas de emprego. No que concerne aos instrumentos de transferências voluntárias das ações e programas de ES, essa Avaliação entende que em relação aos convênios realizados entre esferas de governo (convênios entre governo central, estados e municípios) "não parece evidente para a maioria dos que atuam na máquina pública" e "tende a deslizar como um modismo ao interior das estruturas de governo". Nesse sentido, os avaliadores entendem que o tema exige "da parte dos seus formuladores a necessidade de sua afirmação no interior do aparelho governamental para conseguir mais espaço e legitimação" (p. 6).

Destaca-se, nesse ponto, que os autores proclamam as Universidades como um "parceiro privilegiado" de apoio a ES. Para os avaliadores, as Universidades (públicas, em grande parte) têm empreendido na construção de estruturas de intervenção e apoio ao desenvolvimento dessas políticas por meio, por exemplo, das incubadoras tecnológicas de cooperativas populares, com projetos de natureza essencialmente empreendedora.

No que concerne aos convênios entre governo central e organizações da sociedade civil, os autores concluíram que essa parceria possui "caráter imprescindível como fundamento para realização" das políticas de ES. Isso porque, conforme análise realizada pelos avaliadores (Araújo, 2005), “as políticas de ES supõem necessariamente a participação ou graus variados

\footnotetext{
${ }^{12}$ Informações obtidas no Portal do Sies no link <http://atlas.sies.org.br/?q=are14\&l=0\&g=paises> Acesso em: 15 ago. 2017.
} 
de articulação com a sociedade civil para sua efetividade”, pois representa práticas oriundas da própria sociedade civil (p. 7).

No entanto, a Avaliação destaca que apesar da importância das organizações da sociedade civil, há "pouca relevância das parcerias com sindicatos", o que indica que a ES constitui-se de "um novo tipo de movimento social" (p. 7). Nesse ponto, faz-se importante enfatizar que, diferentemente das políticas de emprego formal cujos atores principais da sociedade civil são os sindicatos, na economia solidária os atores principais da sociedade civil são diversos (universidades, organizações religiosas etc.).

\subsection{Relação entre Teoria, Objeto e Método}

Conforme descrito na seção capítulo 2.1, a TCE sustenta que existe uma série custos de transação nas organizações públicas e que esses custos de transação modelam as escolhas institucionais das organizações.

Zylberztajn (1995) defende que o avanço do rigor formal da TCE está divido em quatro fases: (1a) informal e com um enfoque tautológico, representada pelo trabalho de Coase (1937); (2a) pré-formal, que compara modelos contratuais alternativos, com base em modelos heurísticos, representado pelos trabalhos de Williamson (1985); (3a) semiformal, que são os estudos que comparam estruturas de governança, integração vertical e contratos e; (4a) plenamente formal, com estudos mais pontuais e menos abrangentes, iniciada com os trabalhos de Hart \& Moore (1990).

Nesse aspecto, Zylberztajn (1995) afirma que a TCE possui uma orientação microanalítica, representando um elo entre economia e administração baseado em fundamentos do direito e da sociologia, o que representa uma fonte de aplicação em diversas pesquisas, inclusive em políticas públicas.

Tais pesquisas focaram, primordialmente, em como os aspectos de governança ajudam na minimização dos custos de transação e, consequentemente, na eficiência contratual entre as partes, considerando que os contratos possuem custos associados ao desenho, à implementação, ao monitoramento e à solução de disputas que porventura surjam do seu descumprimento, fazendo com que as organizações e instituições sejam estruturadas com base nesses aspectos, conforme defende Zylberztajn (1995). 
Assim, a partir dos fundamentos de complementariedade das teorias dos custos de transação e da agência defendido nos trabalhos deWilliamson (1981) e Williamson (1983) e a partir dos modelos teóricos de McCubbins \& Page (1987) e Horn (1995), foi construída a Ilustração 5.

Nesse sentido, esta pesquisa é desenvolvida considerando a relação de agência, por meio de variáveis representativas das escolhas institucionais das organizações convenentes (os tipos de organizações convenentes) e os custos de transação, por meio das variáveis relacionadas às características contratuais (convênios).

Desta maneira, as relações teórico-empíricas da Ilustração 5 demonstram que as organizações, públicas e privadas, que são fruto das escolhas institucionais (conforme evidenciaram Levy \& Spiller, 1994; Zylberztajn,1995; Horn, 1995, por exemplo) influenciam e são influenciadas pela relação de agência (agente-principal) e essa relação de agência molda os instrumentos institucionais adotados nas relações contratuais que porventura existam.

Considerando-se que os convênios são, em essência, contratos e fundamentando-se nas teorias apresentadas, nas pesquisas empíricas sobre contratos de serviços públicos sociais no âmbito internacional (Slyke, 2003; Dekker, 2004; Brown, Potoski \& Slyke, 2007; Lecy \& Slyke, 2012; entre outros) e, tendo em vista as políticas públicas de emprego e economia solidária, suas instituições e seus instrumentos de transferências voluntárias, esta pesquisa busca testar, empiricamente, as hipóteses teóricas elencadas na Ilustração 6.

Acredita-se que, em princípio, a estrutura de governança e o desempenho que dão origem aos controles são diferentes para os três tipos de agentes que firmam contratos com o governo central e, por existirem diferenças institucionais entre os agentes, devem existir também discrepâncias na forma de se desempenhar o que foi estabelecido nos contratos firmados por esses agentes, em virtude da relação prévia com o principal (Dekker, 2004).

Empiricamente, isso significa relacionar os convenentes (e suas características) e os convênios firmados entre eles e o governo central. As variáveis representativas da relação de agência são referentes aos grupos de convenentes possíveis para essa política, quais sejam: as entidades privadas sem fins lucrativos, estados, distrito federal e municípios.

Já as informações referentes aos contratos foram construídas a partir da análise e leitura do plano de trabalho, dos planos de execução do convênio e dos relatórios de produtos e serviços bem como os de prestação de contas de cada um dos convênios contidos na amostra. 
Portanto, as variáveis empíricas utilizadas para o desenvolvimento da pesquisa foram classificadas nas categorias relacionada aos agentes (RA) e referentes aos contratos (RC). 
Ilustração 5: Relação entre teoria, objeto e método

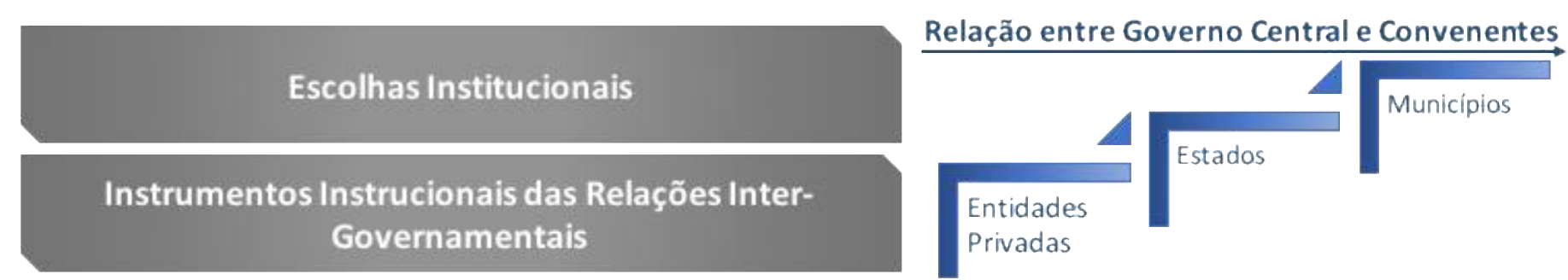

Estrutura de Governança e Desempenho: controles

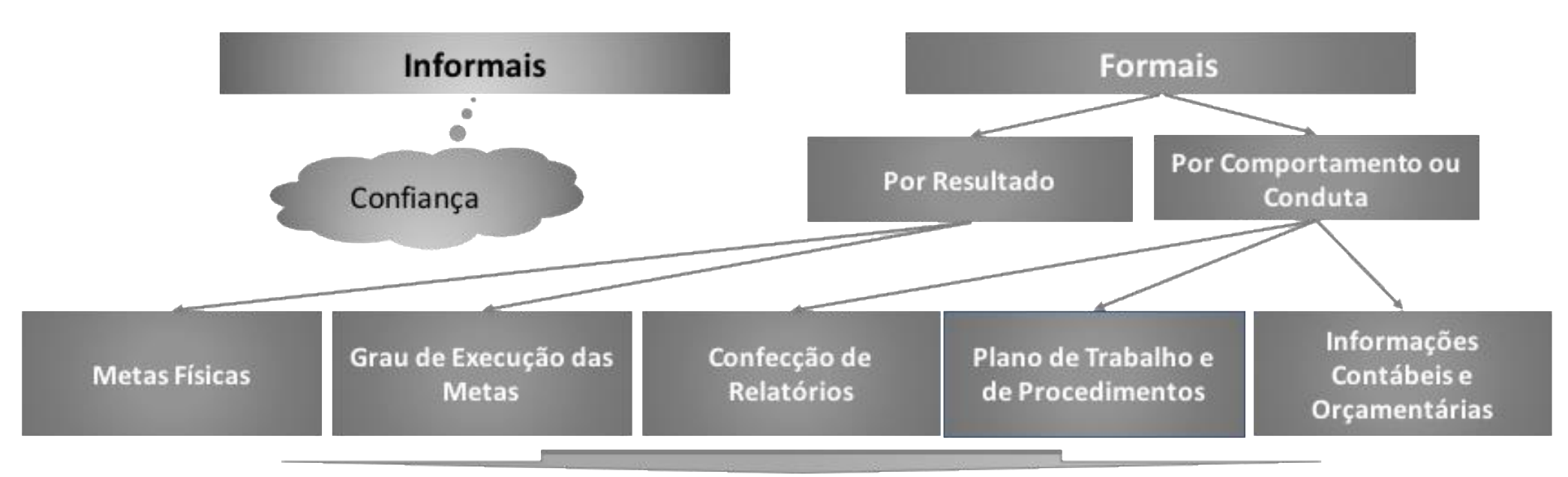

Transferências Voluntárias:

Convênios de Políticas de Trabalho, Emprego e Renda 
Ilustração 6: Relação entre objetivo, hipóteses, literatura e objeto

\begin{tabular}{|c|c|c|c|c|}
\hline Objetivo & Hipótese & Tipo de Análise & $\begin{array}{c}\text { Fundamento teórico } \\
\text { principal }\end{array}$ & Relação teoria-objeto \\
\hline $\begin{array}{l}\text { Verificar como a relação de agência entre as instituições } \\
\text { convenentes e o governo central influencia a gestão e } \\
\text { monitoramento dos arranjos contratuais firmados entre eles. }\end{array}$ & $\begin{array}{l}\text { Há diferenças no estabelecimento de metas e objetivos, na } \\
\text { execução e nos resultados obtidos pelos contratos firmados } \\
\text { em virtude da relação entre agente e principal. }\end{array}$ & Agência (RA) & $\begin{array}{l}\text { Levy \& Spiller (1994), } \\
\text { Horn (1995), Dekker } \\
\text { (2004), Dallaverde (2015) }\end{array}$ & $\begin{array}{l}\text { Os convênios podem ser firmados com entidades privadas sem fins } \\
\text { lucrativos, estados, distrito federal e municípios. As características } \\
\text { organizacionais, como natureza jurídica, nível de hierarquia, processos } \\
\text { decisórios, dependência financeira, engajamento etc. diferem entre os tipos } \\
\text { de convenente e isso reflete no planejamento, execução e resultado dos } \\
\text { contratos firmados. }\end{array}$ \\
\hline $\begin{array}{l}\text { Relacionar a teoria da agência e a teoria dos custos de } \\
\text { transação aplicados ao setor público, em uma perspectiva } \\
\text { complementar. }\end{array}$ & $\begin{array}{l}\text { Os custos das transações contratuais, sobretudo os de } \\
\text { controle e monitoramento, são influenciados pela relação } \\
\text { entre agentes e principal. }\end{array}$ & Agência (RA) & Williamson (1988) & $\begin{array}{l}\text { O controle e o monitoramento dos convênios, que possuem custos } \\
\text { diferentes de zero, são influenciados pela relação de agência entre o governo } \\
\text { central e o tipo de convenente. }\end{array}$ \\
\hline $\begin{array}{l}\text { Verificar os efeitos do indicador de repasse na execução e } \\
\text { prestação de contas dos contratos firmados, em uma } \\
\text { perspectiva da relação de agência. }\end{array}$ & $\begin{array}{l}\text { As diferenças médias no indicador de repasse dos contratos } \\
\text { são explicadas pela relação de agência das instituiçõ̃es } \\
\text { convenentes com o governo central.As alterações no } \\
\text { indicador de repasse promovem alterações na forma como } \\
\text { o contrato é executado e na sua prestação de contas. }\end{array}$ & Contratual (RC) & $\begin{array}{l}\text { Johnston \& Romzek } \\
\text { (2000), Slyke (2003), Lecy } \\
\text { \& Thornton (2016) }\end{array}$ & $\begin{array}{l}\text { Devido à dependência dos convenentes em relação aos recursos federais, } \\
\text { quanto maior o indicador de repasse, menores são as necessidades de } \\
\text { mudanças no plano de trabalho estabelecido e menores são os impactos na } \\
\text { prestação de contas dos convenentes. }\end{array}$ \\
\hline $\begin{array}{l}\text { Propor um modelo de priorização de monitoramento de } \\
\text { contratos baseado nas características dos contratos e na sua } \\
\text { execução. }\end{array}$ & $\begin{array}{l}\text { A existência de determinadas características contratuais e de } \\
\text { execução estão relacionadas a uma probabilidade } \\
\text { significativa de o contrato não ser cumprido. }\end{array}$ & Contratual (RC) & $\begin{array}{l}\text { Hand \& Henley (1996); } \\
\text { Brown, Potoski \& Slyke } \\
\text { (2007); Witesman \& } \\
\text { Fernandez (2012); }\end{array}$ & $\begin{array}{l}\text { Algumas características de execução contratual, tais como mudanças no } \\
\text { plano de trabalho, termos aditivos, rejeição de relatórios podem indicar, a } \\
\text { priori, um possível não cumprimento das metas estabelecidas nos contratos } \\
\text { firmados. }\end{array}$ \\
\hline $\begin{array}{l}\text { Verificar como a relação de agência influencia o } \\
\text { estabelecimento das metas previstas nos contratos. }\end{array}$ & $\begin{array}{l}\text { As metas inicialmente estabelecidas para um mesmo serviço } \\
\text { divergem entre os diferentes tipos de instituições } \\
\text { convenentes. }\end{array}$ & Contratual (RC) & $\begin{array}{l}\text { Saidel (1991), Slyke } \\
\text { (2003), Heinrich \& Choi } \\
\text { (2007) }\end{array}$ & $\begin{array}{l}\text { Quanto mais bem delineadas as metas e objetivos dos convênios celebrados, } \\
\text { maior capacidade de enforcement atribuído aos gestores e, } \\
\text { consequentemente,melhor o desempenho do contrato por meio do } \\
\text { cumprimento das metas pactuadas. }\end{array}$ \\
\hline
\end{tabular}




\section{MÉTODO DE PESQUISA}

\subsection{Coleta de Dados, População e Amostra}

A Tabela 1 evidencia a quantidade de convênios e emendas parlamentares por tipo de convenente até agosto de 2017:

Tabela 1: Quantidade de convênios celebrados e emendas parlamentares por natureza jurídica (entre 2008 e agosto de 2017)

\begin{tabular}{|c|c|c|}
\hline Natureza Jurídica & Quantidade & Emendas parlamentares (\%) \\
\hline $\begin{array}{c}\text { Entidade Privada sem fins } \\
\text { lucrativos }\end{array}$ & 513 & $37,7 \%$ \\
\hline Estado & 331 & $41,7 \%$ \\
\hline Municípios & 276 & $37,7 \%$ \\
\hline Outros & 19 & $47,7 \%$ \\
\hline Total & 1.139 & $100 \%$ \\
\hline
\end{tabular}

Fonte: Portal da Transparência do Governo Federal

Contextualizando, entre o período de 2008 a 2017, foram celebrados 1.139 convênios pelo MTE, dos quais 772 estavam disponíveis no Siconv. Desses 772 contratos selecionados para a amostra, 12 foram anulados ou cancelados e 4 foram objeto de assinatura, controle e monitoramento pelo Gabinete do Ministro ou Secretaria Executiva, restando 756 contratos referentes ao objeto de pesquisa cujo processo de execução e/ou de prestação de contas estavam disponíveis para consulta.

A Tabela 2 evidencia os filtros realizados até a amostra final da pesquisa:

Tabela 2: População e amostra (2008-2017)

\begin{tabular}{|c|c|}
\hline População (até agosto de 2017) & $\begin{array}{c}\text { Quantidade de } \\
\text { contratos }\end{array}$ \\
\hline Disponíveis no SICONV & $\mathbf{1 . 1 3 9}$ \\
\hline Anulados ou Cancelados & $\mathbf{7 7 2}$ \\
\hline Outras secretarias & -12 \\
\hline Amostra & -4 \\
\hline Finalizados & $\mathbf{7 5 6}$ \\
\hline Em execução & 526 \\
\hline
\end{tabular}

Assim, para a confecção desta pesquisa, foram coletados e analisados todos os convênios de transferências voluntárias celebrados pelo MTE e disponíveis para consulta integral no Siconv. É importante salientar que um convênio é composto dos seguintes dados/documentos: 
informações cadastrais do convenente, plano de trabalho, relatórios de execução, relatórios de produtos e serviços e pareces de prestação de contas.

As fontes dos dados de uma pesquisa podem ser classificadas como primárias, secundárias e terciárias (Smith, 2008). Ressalta-se que a maior parte dos dados que compõe o banco de dados foi obtida por meio da análise individual e sistemática de todos os documentos que formam um convênio, o que caracteriza a fonte dos dados como primária.

A coleta dos dados e a confecção do banco de dados foram realizadas entre o período de 01 de novembro de 2016 e 15 de maio de 2017. Assim, em média, foram lidos aproximadamente 15 contratos por dia de, em média, 50 páginas.

\subsection{Dados e variáveis coletados para a construção do banco de dados}

Conforme mencionado na seção de relação entre teoria, objeto e método no capítulo 2 , as variáveis empíricas desta tese podem ser divididas em variáveis relacionadas à relação agenteprincipal (relação de agência - RA) e variáveis referentes aos contratos (relações contratuais $\mathrm{RC})$.

As variáveis pertencentes às classificações RA e RC foram coletadas, individualmente, por contrato. Para cada um dos 756 contratos contidos na amostra final, foram coletados 323 dados referentes ao cadastro, aos objetivos, às metas e aos planejamentos físico e financeiro, à execuçãoe à prestação de contas (essa última, somente para os contratos finalizados).

Para esta pesquisa, parte dos dados coletados foram transformados em aproximadamente 134 variáveis, categóricas (binária e policotômica) e métricas (contínua e discreta). Além da classificação relacionada à literatura, RA e RC, as variáveis também foram distribuídas entre os grupos cadastro, execução e prestação de contas.

Ainda, baseando-se nas informações que representam, as variáveis foram divididas em subgrupos: controle, meta, mudança contratual, parecer, relatórios, transparência etc. A lista completa de variáveis, suas classificações teóricas e seus respectivos grupos são apresentadas na Ilustração 7 no Apêndice B.

A apresentação de determinadas variáveis no corpo do texto importa uma vez que elas serão utilizadas para satisfazer os objetivos da pesquisa por meio da análise empírica que será descrita nas próximas seções. Assim, dentre as variáveis disponíveis, é importante destacar as 
relacionadas ao cumprimento do contrato, à escolha institucional, ao indicador de repasse e às secretarias.

A Tabela 3 elenca, descreve e evidencia a classificação dessas variáveis principais:

Tabela3: Principais variáveis da pesquisa

\begin{tabular}{|c|c|c|c|c|}
\hline $\begin{array}{l}\text { Perspectiva } \\
\text { teórica }\end{array}$ & Variável & Descrição & Grupo & Tipo \\
\hline RA & Escolha institucional & $\begin{array}{l}\text { Agente da relação de agência- tipos organizacionais do } \\
\text { convenentes: entidade privada; estado; município }\end{array}$ & Cadastro & Categórica \\
\hline RA & Secretaria & $\begin{array}{c}\text { Principal da relação de agência - secretaria responsável pela } \\
\text { assinatura, gestão, controle e monitoramento dos contratos: SPPE; } \\
\text { Senaes }\end{array}$ & Cadastro & Categórica \\
\hline $\mathrm{RC}$ & $\begin{array}{l}\text { Cumprimento do } \\
\text { contrato }\end{array}$ & $\begin{array}{l}\text { Cumprimento do contrato: sim (integralmente; parcialmente; não } \\
\text { (não cumprido) }\end{array}$ & $\begin{array}{l}\text { Prestação de } \\
\text { Contas }\end{array}$ & Categórica \\
\hline $\mathrm{RC}$ & $\begin{array}{l}\text { Grau de cumprimento } \\
\text { do contrato }\end{array}$ & $\begin{array}{l}\text { Grau de cumprimento do contrato: integralmente; parcialmente; não } \\
\text { cumprido }\end{array}$ & $\begin{array}{l}\text { Prestação de } \\
\text { Contas }\end{array}$ & Categórica \\
\hline $\mathrm{RC}$ & Indicador de repasse & $\begin{array}{l}\text { Relação entre o valor liberado e valor conveniado para os contratos } \\
\text { finalizados }\end{array}$ & Execução & Métrica \\
\hline
\end{tabular}

A variável indicador de repasse varia entre 0 e 1. Destaca-se que quanto mais próximo do valor um for o indicador de repasse, maior a transferência de recursos feitapelo governo central para o convênio.

\subsection{Procedimentos estatísticos}

a) Estatísticas descritivas e técnicas exploratórias

Com o intuito de apresentar as principais característicasdos dados coletados, foram utilizados procedimentos estatísticos descritivos univariados e bivariados, tais como medidas de posição e de dispersão, de associação entre variáveis qualitativas e de correlação entre variáveis quantitativas.

Adicionalmente, foram empregadas as técnicas exploratórias análise fatorial e análise de correspondência simples e múltipla, antes da elaboração dos modelos confirmatórios, com a finalidade de realizar um diagnóstico acerca do comportamento dos dados, bem como a elaboração de rankings e mapas perceptuais.

É importante salientar que a utilização das técnicas exploratórias nesta pesquisa tem o único objetivo de promover aanálise visual para o leitor, além de demonstrar a necessidade da utilização das técnicas confirmatórias, uma vez que as técnicas exploratórias não possuem poder inferencial. 
b) Conceito de cohort e information value

Para o desenvolvimento da pesquisa, foram utilizados dois conceitos, o de cohort e o de information value (IV).

Preston, Heuveline \& Guillot (2001) definiram cohort como a agregação de todas as unidades que presenciaram um evento particular durante um período de tempo específico (isto é, unidades de análise que compõem uma mesma geração).

Conforme explica Glenn (2005), o conceito de cohort tem sido essencial nos estudos em ciências sociais, tais como demografia, epidemiologia, psicologia, ciência política e sociologia. Portanto, para fins desta tese, uma cohort de contratos refere-se a contratos cujo início de vigência se deu no mesmo período do tempo.

Já information value é uma técnica amplamente utilizada para seleção de variáveis para construção de modelos preditivos, sobretudo para a construção de modelos de crédito e default (ver, por exemplo, Hand \& Henley, 1996;). De uma maneira geral, essa ferramenta se baseia na seleção e análise de variáveis que apresentam maior capacidade de segregar os eventos dos não eventos.

Um exemplo comum elencado na literatura é o da indústria financeira que desenvolve modelos de crédito que contenham variáveis com alto poder de segregar bons e maus pagadores, com vistas a diminuição do risco de crédito da organização. Quanto o maior o poder discriminatório das variáveis presentes no modelo, maior seu information value.

Assim, o cálculo do information value se dá em duas etapas: primeiro, calcula-se o Weight of Evidence (WOE) e posteriormente, o Information Value (IV). O cálculo do WOE é feito da seguinte maneira:

$$
W O E=[\ln (\text { Distribuição dos eventos } \div \text { Distribuição de não eventos }) \times 100](12)
$$

O valor de WOE será zero se a chance da distribuição de eventos/distribuição de não eventos for igual a 1. Se a distribuição de não eventos for maior que a distribuição de eventos, a chance será menor que 1 e, portanto, o WOE será um número negativo. Caso contrário, se a distribuição de eventos for maior que a de não eventos, a chance será maior que $1 \mathrm{e}$, de tal modo, o WOE será um número positivo. 
O IV de uma variável preditora é a soma dos valores absolutos do WOE de todos os grupos dessa variável. Assim, ele representa a quantidade de informação diagnóstico dessa variável preditora que discrimina os eventos dos não eventos.

Assim, para cálculo do $I V$ tem-se:

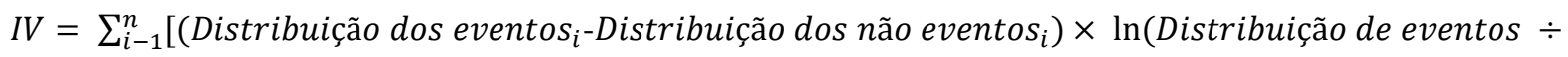
Distribuição de não eventos)](13)

A literatura defende que a utilização do $W O E$ e $I V$ para a escolha dos preditores do modelo é útil quando for construído um modelo de regressão logística. Siddiqi (2006) sugere como os valores de $I V$ das variáveis preditoras podem ser assim interpretados (Tabela 4):

Tabela4: Análise do valo do $I V$

\begin{tabular}{|c|c|}
\hline Resultado & $\begin{array}{c}\text { Grau de discriminação de eventos e } \\
\text { não eventos }\end{array}$ \\
\hline Menor que 0,02 & Inexistente \\
\hline De 0,02 até 0,1 & Fraca \\
\hline De 0,1 até 0,3 & Média \\
\hline Acima de 0,3 & Alta \\
\hline
\end{tabular}

De tal modo, serão calculados os IV das variáveis preditoras categóricas (elencadas no quadro) com o objetivo de verificar quais dessas variáveis possuem maior poder de segregar contratos cumpridos de contratos não cumpridos.

Busca-se, portanto,utilizar essa técnica para se desenvolver um modelo preditivo capaz de prever quais características de cadastro, de execução e de prestação de contas aumentam a probabilidade de um contrato de transferência voluntária ser cumprido ou não. A construção deste modelo, considerando os conceitos de cohort e information value, auxilia no alcance do objetivo específico de estabelecer um modelo de priorização de processos de prestação de contas baseado nas características do contrato, na execução e no ambiente institucional do convenente. 
c) Técnicas confirmatórias e modelos estatísticos para o teste das hipótesesestabelecidas

Para cumprir os objetivos propostos por esta pesquisa, foram desenvolvidas hipóteses. Desta forma, serão utilizadas estatísticas descritivas uni e bivariadas, técnicas exploratórias e técnicas confirmatórias, como mencionado na seção anterior. Em relação às técnicas confirmatórias, serão utilizados osmodelos multiníveis de regressão para dados em painel.

Essa técnica estatística mostra-se adequada porque considera a existência de estrutura aninhadas de dados, ou seja, "em que determinadas variáveis apresentam variações entre unidades distintas que representam grupos, porém não entre informações presentes entre um mesmo grupo”, conforme explicam Fávero \& Belfiore (2017, p. 857).

Portanto, por meio da utilização de modelos multiníveis, busca-se estimar se existe variabilidade na variável dependente proveniente de mudanças nas variáveis independentes e, quanto desta variabilidade é produzida pelo fato de as observações pertencerem a grupos distintos.

Gelman\& Hill (2007) ressaltam que modelos desta natureza podem ser chamados varyingintercept models porque possuem diferentes interceptos para cada grupo. Os autores reiteram que como maior parte das variáveis não são capturadas de maneira randômica, é muito possível que haja entre os grupos características vinculadas às dimensões políticas, econômicas, organizacionais e culturais que diferem entre si. Nesse caso, as unidades de um mesmo nível pertencentem a uma mesma unidade, de nível mais alto, são raramente independentes, visto que compartilham mesmo contexto e características, conforme salienta Tamura et al (2007).

Fávero \& Belfiore (2017) defendem que a maior vantagem da utilização de modelos multinível em detrimento dos modelos tradicionais se dá pelo fato de esses modelos considerarem o aninhamento natural dos dados. Gelman \& Hill (2007) ressaltam que há, realmente, uma complexidade adicional nos modelos multiníveis em virtude de os coeficientes variarem por grupo. No entanto, os autores observam que o pesquisador não deve se preocupar com essa complexidade, uma vez que há, nesse tipo de modelo, bastante realismo.

Portanto, modelos multíniveis permitem que sejam analisadas tanto as diversidades individuais quanto as provenientes entre grupos aos quais os indivíduos estão contidos.

Desta maneira, a Ilustração 8, retirada de Fávero \& Belfiore (2017), exemplifica o aninhamento dos dados para utilização de modelos multinível. Esta estrutura de dados apresenta 
aninhamento absoluto, conforme ressaltam os autores. Isso significa que um indivíduo pertence somente a um grupo, formando os chamados modelos hierárquicos (HM).

Ilustração 8: Exemplo de aninhamento dos dados (Fávero \&Belfiore, 2017)

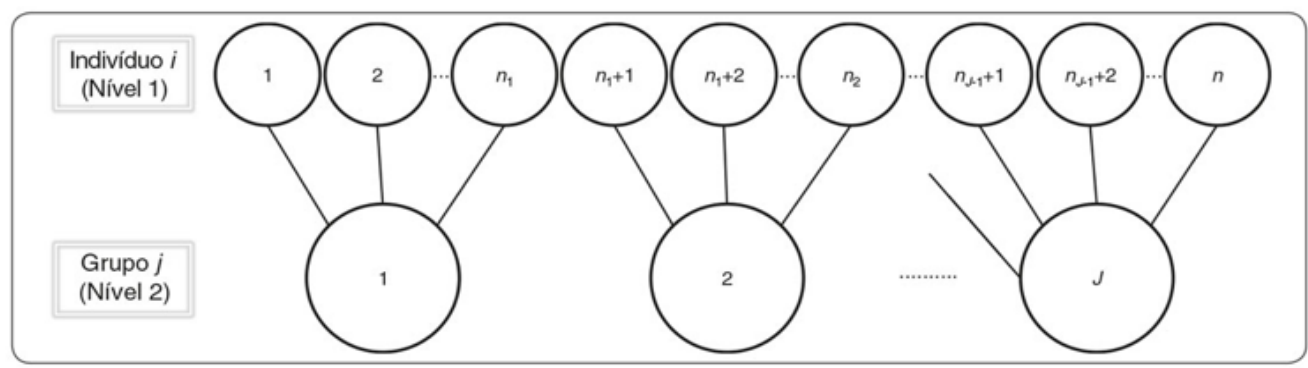

Os modelos hierárquicos (ou multinível) podem ser classificados em lineares e não lineares. Para fins desta tese, serão utilizados tanto os modelos hierárquicos lineares quanto os modelos não lineares (logísticos binários e multinomiais e modelos para dados de contagem), conforme a hipótese e a variável dependente a ser testada.

Para os casos em que os modelos hierárquicos não sejam a melhor forma de estimação, serão utilizados os mesmos modelos, lineares e não lineares, na forma tradicional.

a) Modelos hierárquicos lineares (HLM)

Os modelos hierárquicos lineares são utilizados quando a variável dependente for métrica e contínua, e os dados estiverem dispostos em uma estrutura aninhada (semelhante à representada na Ilustração 8). Desta maneira, um modelo hierárquico linear de dois níveis, pode ser representado de forma geral:

Nível 1

$$
Y_{i j}=\beta_{0 j}+\sum_{q=1}^{Q} \beta_{q j} \times X_{q i j}+r_{i j}
$$

Nível 2

$$
\beta_{q j}=\gamma_{q 0}+\sum_{s=1}^{S} \gamma_{q s} \times W_{s j}+u_{q j}
$$

em que $\mathrm{Y}$ representa o fenômeno de estudo, $\mathrm{X}_{1}, \ldots, \mathrm{X}_{\mathrm{Q}}$ são as variáveis explicativas (métricas ou categóricas) referentes a cada indivíduo no nível 1 e as variáveis explicativas $\mathrm{W}_{1}, \ldots, \mathrm{W}_{\mathrm{S}}$ 
referentes ao nível 2 de grupo j em que $q=0,1, \ldots, \mathrm{Q}$ e $\mathrm{s}=1,2, \ldots, \mathrm{S}_{\mathrm{q}}$, a depender do tipo do modelo construído.

O HLM leva em consideração o fato de que para as diversas amostras, diferentes coeficientes podem ser computados, um para cada grupo. Desta maneira, esses modelos tratam os coeficientes betas computados como efeitos aleatórios oriundos de uma distribuição normal de possíveis coeficientes, diferentemente dos modelos tradicionais, que tratam os parâmetros betas como se fossem fixos (Garson,2013).

Assim, esses modelos retratam as diferenças entre grupos (por exemplo, organizações) em relação às diferenças intragrupos (entre observações do mesmo tipo organizacional). Ao se utilizar HLM, podem ser computados, geralmente, três modelos:

O modelo nulo cujo o objetivo é determinar se existe efeito do nível 2 (organização) na média da variável dependente de nível 1 (valor liberado, por exemplo). Adicionalmente, por meio desse modelo, é possível verificar se a estatística de interclass correlation (ICC) é significativa estatisticamente. Trata-se de um tipo de modelo que considera o intercepto de nível 1 como um efeito aleatório da variável de grupo do nível 2, sem nenhuma outra covariada no nível 1 ou nível 2. A Ilustração 9 exemplifica este modelo:

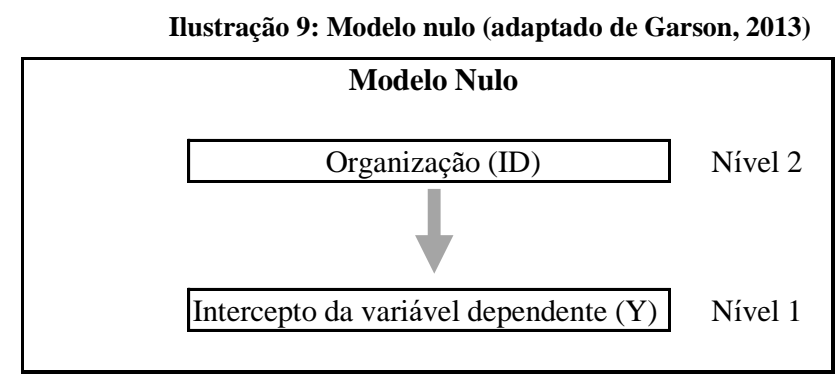

Os modelos de interceptos aleatórios são modelos de regressão em que a variável dependente de nível 1 (Y) é prevista por pelo menos uma covariada de nível 1 (X). O coeficiente desta covariada $(\mathrm{X})$ e o intercepto do modelo são computados pelos efeitos aleatórios da variável de grupo de nível 2. Ou seja, assume-se que cada grupo do nível superior (organização) possui diferentes inclinações e interceptos que influenciam na previsão da variável dependente (Y) de nível 1. Por fim, o modelo de interceptos e inclinações aleatórias são em que as inclinações e os interceptos são modelados não somente pelas variáveis de nível 2 como fator de efeitos aleatórios, mas por uma ou mais covariadas (W) de nível 2 
A Ilustração 10 exemplifica esses modelos:

Ilustração 10: Modelo com interceptos aleatórios e modelos com interceptos e inclinações aleatórias (adaptado de Garson, 2013)

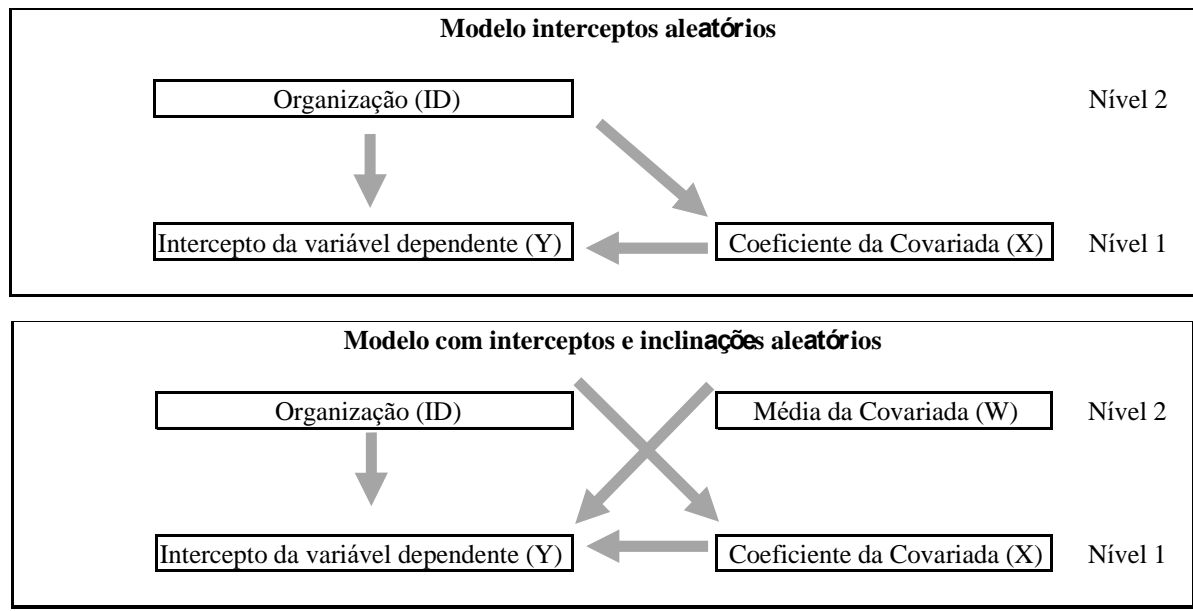

Além disso, os modelos hierárquicos podem ser estimados, geralmente, por duas maneiras: maximum likelihood (ML) e por restricted maximum likelihood (REML). Conforme aponta a literatura (ver, Garson, 2003; Fávero \& Belfiore, 2017), os modelos REML geram valores melhores, isto é, estimações não viesadas das variâncias dos termos de erro, quando comparados com os modelos ML. O modelo REML é restrito pelo fato da função likelihood incluir somente componentes de variância. A literatura ressalta ainda que, o uso do REML é recomendado quando o tamanho da amostra é relativamente pequeno.

b) Modelos hierárquicos não lineares (HNLM)

Os modelos hierárquicos não lineares logísticos binários e multinomiais são utilizados quando a variável dependente se apresentarna forma qualitativa, dicotômica e policotômica, dispostas em uma estrutura aninhada (conforme evidenciado na Ilustração 8).

Baseando-se em Fávero \& Belfiore (2017), o modelo com dois níveis de análise, em que o primeiro nível oferece as variáveis explicativas $\mathrm{X}\left(\mathrm{X}_{1}, \mathrm{X}_{2}, \ldots \mathrm{X}_{\mathrm{q}}\right)$ referentes a cada observação $\mathrm{i}(\mathrm{i}=1,2, \ldots \mathrm{n})$ e o segundo nível as variáveis explicativas $\mathrm{W}\left(\mathrm{W}_{1}, \mathrm{~W}_{2}, \ldots \mathrm{W}_{\mathrm{q}}\right)$ referentes a cada grupo $\mathrm{j}(\mathrm{j}=1,2, \ldots \mathrm{n})$ para o modelo hierárquico não linear logístico é: 


$$
\rho_{i j=} \frac{1}{1+e^{-\left(\beta_{0 j}+\beta_{1 j^{\times X}}\right.} 1 i j^{\left.+\beta_{2 j} \times X_{2 i j^{+\ldots}}+\beta_{Q j} \times X_{Q i j}\right)}}
$$

em que $\rho_{\mathrm{ij}}$ é a probabilidade de ocorrência do evento de interesse para cada observação $i$ pertencente a um grupo $j$ e $\beta_{\mathrm{qj}}(\mathrm{q}=0,1,2, \ldots, \mathrm{Q})$ são os coeficientes do nível 1.

Nivel 2

$$
\beta_{q j}=\gamma_{q 0}+\sum_{s=1}^{S q} \gamma_{q s} \times W_{s j}+u_{q j}(17)
$$

em que $\gamma_{\mathrm{q} 0}\left(\mathrm{~s}=0,1, \ldots, \mathrm{S}_{\mathrm{q}}\right)$ são os coeficientes de nível 2 e $u_{q j}$ são os efeitos aleatórios do nível 2. Adicionalmente, eventuais termos de erro independentes de $u_{q j}$ apresentam média igual a zero e variância igual a $\pi^{2} / 3$.

Assim, ao utilizar esses modelos, o objetivo do usuário é verificar a relação entre o comportamento das variáveis explicativas e a ocorrência de um ou mais eventos e, ainda, analisar a decomposição de variância dos componentes aleatórios decorrentes da estrutura multinível.

De forma análoga, os modelos hierárquicos não lineares para dados em contagem são empregados quando a variável dependente for mensurada na forma métrica com valores discretos e não negativos.

O modelo hierárquico não linear logístico para dados de contagem considerando dois níveis, em que o primeiro nível apresenta as variáveis explicativas $Z_{1}, Z_{2}, \ldots, Z_{p}$ referentes às unidades $\mathrm{i}(\mathrm{i}=1, \ldots, \mathrm{n})$ de nível $1 \mathrm{e}$ as variáveis $\mathrm{X}_{1}, \mathrm{X}_{2}, \ldots, \mathrm{X}_{\mathrm{q}}$ referentes às unidades $\mathrm{j}(\mathrm{j}=1,2, \ldots, \mathrm{J}) \mathrm{de}$ nível 2 e invariantes para as unidades pertencentes ao mesmo grupo é:

Nível 1

$$
\ln \left(\lambda_{i j}\right)=\pi_{0 j}+\pi_{1 j} \times Z_{1 i j}+\pi_{2 j} \times Z_{2 i j}+\pi_{P j} \times Z_{P i j}
$$

em $\lambda$ é a taxa média de incidência do fenômeno em estudo para a exposição, $\pi_{\mathrm{pj}}(\mathrm{p}=0,1,2, \ldots$, P) são os coeficientes de nível 1 e os $Z_{\mathrm{pj}}$, a p-ésima variável do nível 1 para a unidade $i$ de nível $2, j$. 


$$
\pi_{p q}=\gamma_{p q 0}+\sum_{q=1}^{Q_{p}} b_{p q} \times X_{q j}+r_{p j}
$$

em que $b_{\mathrm{pq}}\left(\mathrm{q}=0,1,2, \ldots, \mathrm{Q}_{\mathrm{p}}\right)$ são os coeficientes de nível 2, $\mathrm{X}_{\mathrm{qj}}$ é a q-ésima variável explicativa do nível 2 para unidade $j$ e $\mathrm{r}_{\mathrm{pj}}$, são os efeitos aleatórios do nível 2.

Ao explicarem os modelos para dados de contagem, Fávero \& Belfiore (2017) chamam a atenção para o fato de que é comum, para determinadas variáveis de contagem, uma quantidade excessiva de zeros, o que pode fazer com que os parâmetros estimados sejam viesados por não conseguirem capturar a presença acentuada de contagens nulas.

Os autores sugerem, nesses casos, a utilização de modelos de regressão inflacionados de zero, que são estimados a partir da combinação de uma distribuição Bernoulli com uma distribuição Poisson. A definição da existência ou não de quantidade excessiva de zeros na variável dependente é verificada por meio do teste de Vuong (Fávero \& Belfiore, 2017).

Rejeitada a hipótese de que não há inflações de zero nas variáveis de contagem, o modelo inflacionado de zero é dado por:

$$
\begin{gathered}
p\left(Y_{i}=0\right)=p_{\text {logit }}+\left(1-p_{\text {logit }}\right) \cdot e^{-\lambda i}(20) \\
p\left(Y_{i}=m\right)=\left(1-p_{\text {logit }}\right) \cdot \frac{e^{\lambda_{i}} \cdot \lambda_{i}^{m}}{m !}(21)
\end{gathered}
$$

Sendo $m=1,2, \ldots$ e sabendo que:

$$
\begin{aligned}
p_{\text {logit }} & =\frac{1}{1+e^{-\left(\gamma+\delta_{1} \cdot W_{1 i}{ }^{+} \delta_{2} \cdot W_{2 i}+\cdots+\delta_{q} \cdot W_{q i}\right)}} \\
\lambda_{i} & =e^{\left(\alpha+\beta_{1} \cdot X_{1 i}+\beta_{2} \cdot X_{2 i}+\cdots+\beta_{k} \cdot X_{k i}\right)}(23)
\end{aligned}
$$

Ou seja, $p\left(Y_{i}=0\right)$, calculado considerando a soma de um componente dicotômico com um componente de contagem, a probabilidade de ocorrência de $p\left(Y_{i}=m\right)$. Os modelos inflacionados de zero apresentam dois processos geradores de zero, sendo um devido à distribuição binária e outro referente à distribuição Poisson.

No caso dos contratos analisados, como cada uma das metas pode estar presente em um ou em todos os contratos, a utilização de modelos de dados de contagem inflacionados de zero parece 
adequada e serão utilizados para testar a hipótese de que as metas estabelecidas são diferentes entre os tipos de convenente, caso o resultado do teste de Vuong indique a necessidade.

\subsection{Relação entre hipóteses da pesquisa e procedimentos empíricos}

Baseado no exposto e considerando o objeto da presente pesquisa, os modelos foram confeccionados relacionando os convenentes e suas características, os convênios firmados entre o governo central e seus parceiros e o grau de alcance das metas estabelecidas na relação contratual.

Para os modelos construídos, a variável de nível 2 é escolha institucional, que, nesta pesquisa, é uma variável categórica policotômica representada pelos tipos de convenente. A escolha do procedimento estatístico multinível é condizente com a construção teórica adotada na pesquisa: as organizações e suas escolhas institucionais são influenciadas pela relação agente-principal (que possuem com o governo central) e essa relação influencia os instrumentos institucionais que são adotados nas relações contratuais.

Em outras palavras, uma parte do cumprimento do contrato vincula-se aos dispositivos previstos no próprio contrato, como as características cadastrais, de execução e de prestação de contas; entretanto, o tipo de instituição que implementa este contrato, e que possui uma relação de agência única com o principal, também pode influenciar, a priori, a forma como o contrato será executado, controlado e monitorado.

Para os modelos multíniveis, foram construídos modelos nulos, de interceptos aleatórios e de interceptos e inclinações aleatórias. As variáveis dependentes e independentes (de nível 1 e nível 2) incluídas em cada modelo serão identificadas no momento da análise dos resultados.

Apesar de os modelos hierárquicos se apresentarem como os mais adequados à fundamentação teórica da pesquisa, sua estimação nem sempre é possível. Nesses casos, serão estimados modelos tradicionais a fim de testar as das hipóteses da pesquisa e, consequentemente, alcançar os objetivos propostos.

Para cada hipótese da pesquisa testada, serão utilizados os procedimentos estatísticos e variáveis descritas na Ilustração 11: 
Ilustração 11: Relação entre hipóteses, procedimentos estatísticos e variáveis empíricas

\begin{tabular}{|c|c|c|c|}
\hline Objetivos & Hipóteses & Procedimentos estatísticos & Operacionalização empírica \\
\hline $\begin{array}{l}\text { Verificar como a relação de agência entre as } \\
\text { instituições convenentes e o governo central } \\
\text { influencia a gestão e monitoramento dos arranjos } \\
\text { contratuais firmados entre eles. }\end{array}$ & $\begin{array}{l}\text { Há diferenças no estabelecimento de metas e objetivos, na execução e } \\
\text { nos resultados obtidos pelos contratos firmados em virtude da relação } \\
\text { entre agente e principal. }\end{array}$ & $\begin{array}{l}\text { Análise de correspondência simples e múltipla e } \\
\text { análise fatorial por componentes principais }\end{array}$ & $\begin{array}{l}\text { Indicador de repasse; escolha institucional; grau de } \\
\text { cumprimento e variáveis classificadas como meta } \\
\text { (Ilustração 7) }\end{array}$ \\
\hline $\begin{array}{l}\text { Verificar os efeitos do indicador de repasse na } \\
\text { execução e prestação de contas dos contratos } \\
\text { firmados, em uma perspectiva da relação de agência. }\end{array}$ & $\begin{array}{l}\text { As diferenças médias no indicador de repasse dos contratos são } \\
\text { explicadas pela relação de agência das instituições convenentes com o } \\
\text { governo central. As alterações no indicador de repasse promovem } \\
\text { alterações na forma como o contrato é executado e na sua prestação de } \\
\text { contas. }\end{array}$ & Modelos hierárquicos lineares & $\begin{array}{l}\text { Indicador de repasse; escolha institucional; grau de } \\
\text { cumprimento e variáveis classificadas nas } \\
\text { categorias cadastro, execução, relatórios e parecer } \\
\text { (Ilustração 7) }\end{array}$ \\
\hline $\begin{array}{l}\text { Propor um modelo de priorização de monitoramento } \\
\text { de contratos baseado nas características dos } \\
\text { contratos e na sua execução. }\end{array}$ & $\begin{array}{l}\text { A existência de determinadas características contratuais e de execução } \\
\text { estão relacionadas a uma probabilidade significativa de o contrato não } \\
\text { ser cumprido. }\end{array}$ & $\begin{array}{l}\text { Modelos hierárquicos não lineares logísticos, } \\
\text { modelos logísticos tradicionais e cálculo do } \\
\text { information value }\end{array}$ & $\begin{array}{l}\text { Indicador de repasse; escolha institucional; grau de } \\
\text { cumprimento e variáveis classificadas nas } \\
\text { categorias cadastro, execução e relatórios(Ilustração } \\
\text { 7) }\end{array}$ \\
\hline $\begin{array}{l}\text { Verificar como a relação de agência influencia o } \\
\text { estabelecimento das metas previstas nos contratos. }\end{array}$ & $\begin{array}{l}\text { As metas inicialmente estabelecidas para um mesmo serviço divergem } \\
\text { entre os diferentes tipos de instituições convenentes. }\end{array}$ & $\begin{array}{l}\text { Modelos hierárquicos não lineares para dados em } \\
\text { contagem e modelos para dados em contagem } \\
\text { inflacionados de zero }\end{array}$ & $\begin{array}{l}\text { Indicador de repasse; escolha institucional; grau de } \\
\text { cumprimento e variáveis classificadas como meta } \\
\text { (Ilustração 7) }\end{array}$ \\
\hline
\end{tabular}




\section{RESULTADOS}

O objetivo deste capítulo é descrever os resultados da pesquisa, que serão apresentados em seções. Primeiramente, serão apresentadas as características gerais dos contratos analisados, por meio das técnicas de estatísticas descritivas uni e bivariadas e da análise visual proporcionada pelas técnicas exploratórias. Em seguida, serão evidenciados os resultados obtidos por meio das técnicas confirmatórias.

\subsection{Características gerais dos contratos analisados}

\section{I) Contratos gerais}

Os contratos de serviços públicos sociais apresentam, conforme aponta a literatura, características próprias, principalmente em virtude de as políticas públicas sociais serem implementadas por meio de programas que possuem (i) metas e resultados complexos de se avaliar e mensurar; (ii) clientes com diferentes níveis de necessidade, de demanda e de motivação; e (iii) o predicado (complicador) da continuidade.

Desta maneira, esta seção demonstra os aspectos gerais dos contratos de políticas públicas de emprego e de economia solidária no Brasil, oriundas de programas públicos desenhados pelo governo central.

A Tabela 5 sumariza as informações referentes às principais características dos contratos analisados.

Tabela 5: Quantidade e percentual de contratos por cohort e escolha institucional analisados (em \%)

\begin{tabular}{|} 
Tabela 5: Quantidade e percentual de contratos por cohort e escolha institucional analisados (em \%) \\
\begin{tabular}{|c|c|c|c|c|c|c|}
\hline & \multicolumn{3}{|c|}{ Escolha Institucional } & \multicolumn{2}{c|}{ Secretaria responsável } \\
\hline Cohort & Entidade Privada & Estado & Município & SPPE & Senaes & 11,1 \\
\hline 2008 & 75,4 & 15.2 & 9,4 & 88,9 & 100,0 \\
\hline 2009 & 69,6 & 0,0 & 30,4 & 67,0 & 33,0 & 100,0 \\
\hline 2010 & 72,4 & 6,0 & 21,6 & 62,1 & 37,9 & 100,0 \\
\hline 2011 & 22,6 & 34,0 & 43,4 & 34,0 & 66,0 & 100,0 \\
\hline 2012 & 20,6 & 28,5 & 50,9 & 64,0 & 36,0 & 100,0 \\
\hline 2013 & 51,5 & 26,5 & 22,1 & 5,9 & 94,1 & 100,0 \\
\hline 2014 & 64,7 & 11,8 & 23,5 & 11,8 & 88,2 & 100,0 \\
\hline 2015 & 0,0 & 25,0 & 75,0 & 0,0 & 100,0 & 100,0 \\
\hline 2016 & 0,0 & 100,0 & 0,0 & 0,0 & 100,0 & 100,0 \\
\hline Total & $\mathbf{5 2 , 0}$ & $\mathbf{1 7 , 7}$ & $\mathbf{3 0 , 3}$ & $\mathbf{6 0 , 8}$ & $\mathbf{3 9 , 2}$ & $\mathbf{1 0 0 , 0}$ \\
\hline
\end{tabular}
\end{tabular}


A Tabela 5 evidencia que 52\% dos contratos analisados foram firmados com organizações da sociedade civil; $17,7 \%$ com estados e distrito federal; e 30,3\% com os municípios. Desses contratos, 60,8 \% e 39,2\% estão sob responsabilidade da SPPE e Senaes, respectivamente.

Baseado nisso, um teste de associação entre a variável cohort e a variável escolha institucional evidenciou uma associação não aleatória entre as duas variáveis (estatística do qui-quadrado igual a 210,72 e p-valor igual a 0,000). Esse resultado indica que há uma associação entre o ano que o contrato foi firmado e a quantidade de contratos com organizações da sociedade civil, estados e municípios.

Outra informação importante que pode ser retirada da análise da Tabela 5 é sobre a evolução dos objetos contratados ao longo do período de análise. Observa-se que, a partir de 2013, há um aumento significativo da quantidade de contratos vinculados às políticas de economia solidária (Senaes) em relação aos referentes às políticas de emprego (SPPE).

A média percentual de contratos firmados ligados à SPPE no período de 2008-2012 foi de $63,2 \%$. No período de 2013-2016, esse percentual médio cai para 4,4\%. Para os contratos vinculados à Senaes, a média percentual subiu de 36,8\% (2008-2012) para 96,6\% (2013-2016).

As políticas de emprego são extremamente sensíveis a mudanças econômicas. Portanto, os contratos analisados acompanham a situação econômica do país que, a partir de 2013, obteve aumentos sucessivos de desemprego e queda da oferta de trabalho formal; o que promoveu um incentivo natural à busca de renda pela população ativa por meio de meios alternativos, tais como empreendedorismo e economia solidária. Os resultados dos testes de associação realizados sugerem que há uma associação não aleatória e estatisticamente significativa entre a variável cohort e a quantidade de contratos firmados por secretaria (estatística do qui-quadrado igual a 186,45 e p-valor igual a 0,000$)$.

As associações encontradas são aleatórias e estatisticamente significantes para análise das variáveis secretaria e escolha institucional, indicando que não há indícios de que as secretarias tendam a firmar mais contratos com um tipo específico de organização.

A Tabela 6 evidencia as estatísticas descritivas das principais variáveis métricas dos contratos analisados: valor conveniado, valor liberado, contrapartida e tempo do contrato em dias.

As estatísticas descritivas revelam que há uma variabilidade considerável entre os valores executados nos contratos, uma vez que o coeficiente de variação (CV) das variáveis métricas 
só é menor que 30\% para as variáveis tempo de contrato das cohorts 2012, 2013 e 2015. Conforme afirmam Fávero \& Belfiore (2017), CVs acima de 30\% indicam heterogeneidade nos dados.

Tabela 6: Estatísticas descritivas das principais variáveis métricas (geral e por cohort)

\begin{tabular}{|c|c|c|c|c|c|c|c|}
\hline & Variável & Observações & Média & Desvio-padrão & Mínimo & Máximo & $\mathrm{CV}$ \\
\hline \multirow{4}{*}{$\begin{array}{l}\bar{\Xi} \\
\mathbb{5}\end{array}$} & Valor liberado & \multirow{4}{*}{756} & $1.552 .376,0$ & $3.882 .492,0$ & 0,0 & $66.100 .000,0$ & 250,1 \\
\hline & Valor conveniado & & $2.609 .917,0$ & $5.782 .900,0$ & 38.400 .0 & $66.100 .000,0$ & 221,6 \\
\hline & Contrapartida & & $213.041,7$ & $532.395,8$ & 0,0 & $6.094 .710,0$ & 249,9 \\
\hline & Tempo do contrato (em dias) & & \begin{tabular}{|l|}
$1.181,5$ \\
\end{tabular} & 551,6 & 58,0 & $2.997,0$ & 46,7 \\
\hline \multirow{4}{*}{$\stackrel{\infty}{\stackrel{్}{్}}$} & Valor liberado & \multirow{4}{*}{171} & $1.789 .819,0$ & $5.852 .824,0$ & 0,0 & $66.100 .000,0$ & 327,0 \\
\hline & Valor conveniado & & $2.104 .677,0$ & $5.870 .697,0$ & $38.400,0$ & $66.100 .000,0$ & 278,9 \\
\hline & Contrapartida & & 140.708 .7 & $318.014,4$ & 0,0 & $2,945,720,0$ & 226,0 \\
\hline & Tempo do contrato (em dias) & & 868,7 & 363,0 & 336,0 & $2.997,0$ & 41,8 \\
\hline \multirow{4}{*}{ ठ્ণ } & Valor liberado & \multirow{4}{*}{112} & $834.653,2$ & $1.072 .416,0$ & 0,0 & $7.840 .000,0$ & 128,5 \\
\hline & Valor conveniado & & $1.037 .054,0$ & $1.063 .852,0$ & $99.927,1$ & $7.840 .000,0$ & 102,6 \\
\hline & Contrapartida & & $74.165,1$ & $82.357,1$ & 0,0 & $520.214,4$ & 111,0 \\
\hline & Tempo do contrato (em dias) & & 811,9 & 456,1 & 75,0 & $2.745,0$ & 56,2 \\
\hline \multirow{4}{*}{$\stackrel{\circ}{\stackrel{2}{\sim}}$} & Valor liberado & \multirow{4}{*}{116} & $692.430,7$ & $1.187 .430,0$ & 0,0 & $9.291 .511,0$ & 171,5 \\
\hline & Valor conveniado & & $1.048 .836,0$ & $1.386 .991,0$ & $89.812,5$ & $9.291 .511,0$ & 132,2 \\
\hline & Contrapartida & & $83.586,0$ & $175.821,0$ & 0,0 & $1.666 .384,0$ & 210,3 \\
\hline & Tempo do contrato (em dias) & & 866,6 & 462,2 & 362,0 & $2.370,0$ & 53,3 \\
\hline \multirow{4}{*}{$\overline{\vec{d}}$} & Valor liberado & \multirow{4}{*}{53} & $992.027,7$ & $939.806,7$ & 0,0 & $4.140 .000,0$ & 94,7 \\
\hline & Valor conveniado & & $1.282 .498,0$ & $910.988,2$ & $99.792,0$ & $4.140 .000,0$ & 71,0 \\
\hline & Contrapartida & & $165.088,5$ & $190.797,0$ & 0,0 & $870.000,0$ & 115,6 \\
\hline & Tempo do contrato (em dias) & & $1.489,6$ & 700,3 & 479,0 & $2.557,0$ & 47,0 \\
\hline \multirow{4}{*}{$\stackrel{ }{\vec{\nu}}$} & Valor liberado & \multirow{4}{*}{214} & $2.052 .458,0$ & $4.132 .519,0$ & 0,0 & $28.900 .000,0$ & 201,3 \\
\hline & Valor conveniado & & $4.420 .999,0$ & $7.233 .109,0$ & $100.000,0$ & $54.900 .000,0$ & 163,6 \\
\hline & Contrapartida & & $419.394,5$ & $856.400,7$ & 0,0 & $6.094 .710,0$ & 204,2 \\
\hline & Tempo do contrato (em dias) & & $1.689,8$ & 312,5 & 58,0 & $2.190,0$ & 18,5 \\
\hline \multirow{4}{*}{$\stackrel{m}{\vec{d}}$} & Valor liberado & \multirow{4}{*}{68} & $2.561 .983,0$ & $4.248 .049,0$ & $100.000,0$ & $32.500 .000,0$ & 165,8 \\
\hline & Valor conveniado & & $4.257 .206,0$ & $8,706,142,0$ & $100.000,0$ & $66.000 .000,0$ & 204,5 \\
\hline & Contrapartida & & $234.818,4$ & $490,919,6$ & 0,0 & $3.476 .186,0$ & 209,1 \\
\hline & Tempo do contrato (em dias) & & $1.356,6$ & 205,9 & $1.062,0$ & $1.942,0$ & 15,2 \\
\hline \multirow{4}{*}{$\underset{\sim}{\stackrel{\Delta}{c}}$} & Valor liberado & \multirow{4}{*}{17} & $1.603 .701,0$ & $2,390,435,0$ & $150.000,0$ & $9.809 .675,0$ & 149,1 \\
\hline & Valor conveniado & & $4.054 .505,0$ & $8,432,036,0$ & $150.000,0$ & $32.300 .000,0$ & 208,0 \\
\hline & Contrapartida & & $259.315,1$ & $484,690,6$ & 0,0 & $1.710 .877,0$ & 186,9 \\
\hline & Tempo do contrato (em dias) & & $1.059,1$ & 352,0 & 542,0 & 182,0 & 33,2 \\
\hline \multirow{4}{*}{$\stackrel{n}{\stackrel{\sim}{~}}$} & Valor liberado & \multirow{4}{*}{4} & $172.500,0$ & $80,570,9$ & $60,000,0$ & $250.000,0$ & 46,7 \\
\hline & Valor conveniado & & $425.000,0$ & $170,782,5$ & $200,000,0$ & $600.000,0$ & 40,2 \\
\hline & Contrapartida & & $29.564,1$ & $23,523,8$ & $8.399,7$ & $50.000,0$ & 79,6 \\
\hline & Tempo do contrato (em dias) & & 477,5 & 139,0 & 357,0 & 678,0 & 29,1 \\
\hline \multirow{4}{*}{ 号 } & Valor liberado & \multirow{4}{*}{1} & . & 0,0 & 0,0 & . &. \\
\hline & Valor conveniado & & $1.200 .000,0$ &. & $1.200 .000,0$ & 1.200 .000 .0 & 5 \\
\hline & Contrapartida & & $1.500,0$ & . & $1.500,0$ & $1.500,0$ & . \\
\hline & Tempo do contrato (em dias) & & 579,0 & . & 579,0 & 579,0 & \\
\hline
\end{tabular}

Todavia, os autores sugerem que a análise do CV depende da aplicação. Nesse caso, os valores apresentados são para todos os contratos analisados e não foram segregados na análise o objeto contratado, o que pode influenciar a interpretação dos resultados. Essa análise é feita na seção seguinte, que contempla os contratos finalizados presentes na amostra. 
Foram realizados dois testes para médias populacionais: Anova de um fator e Kruskal-Wallis, paramétrico e não paramétrico, respectivamente. Fávero \& Belfiore (2017) esclarecem que a Anova de um fator é a extensão do teste $t$ de Student que permite a comparação de três ou mais médias populacionais. Fávero et al. (2009) explicam que esse teste permite verificar o efeito de uma variável explicativa de natureza qualitativa em uma variável métrica. A hipótese nula desse teste é que as médias são iguais; se existir pelo menos um grupo com média diferente, a hipótese nula é rejeitada.

Assim, os testes foram realizados para as variáveis valor liberado, valor conveniado, contrapartida e tempo de contrato, considerando como fatores o tipo de organização contratada e a cohort a qual pertencia o contrato. Para todos os testes efetuados, a hipótese nula da igualdade de médias foi rejeitada.

Esse resultado indica que há diferenças nos valores liberados e conveniados, na contrapartida e no tempo do contrato entre os tipos de organização. Resultado similar foi verificado para variável cohort, indicando que há diferenças entre as gerações de contratos para as variáveis métricas analisadas (os valores das estatísticas e seus respectivos p-valores podem ser vistos na Tabela 7).

Vale salientar que a Anova possui três premissas fortes, quais sejam: (i) homoscedasticidade, normalidade dos resíduos e independência das observações, as quais não foram concomitantemente observadas nos dados analisados. Por isso, foi executado outro teste, não paramétrico e menos robusto e alternativo à Anova, o teste de Kruskal-Wallis.

Os testes de Kruskal-Wallis foram executados para as mesmas variáveis métricas utilizadas na Anova e considerando os mesmos fatores. De maneira similar aos resultados da Anova, a hipótese nula da igualdade de médias também foi rejeitada tanto para escolha institucional quanto para cohort.

Os resultados sugerem que há diferenças de distribuição dos valores liberados e dos conveniados, da contrapartida e do tempo contratualentre os tipos de organizações e entre as gerações de contratos, conforme pode ser visto na Tabela 7. 
Tabela 7: Resultados dos testes Anova e Kruskal-Wallis

\begin{tabular}{|c|c|c|c|c|c|}
\hline \multirow{2}{*}{ Variáveis } & \multirow{2}{*}{ Teste } & \multicolumn{2}{|c|}{ Tipo de organização } & \multicolumn{2}{|c|}{ Cohort } \\
\hline & & Estatística & P-valor & Estatística & P-valor \\
\hline Valor liberado & Anova $(F)$ & 6,40 & 0,00 & 2,55 & 0,01 \\
\hline \multirow{2}{*}{ Valor conveniado } & Anova $(\mathrm{F})$ & 13,82 & 0,00 & 6,49 & 0,00 \\
\hline & Kruskal-Wallis (Qui-Quadrado) & 46,06 & 0,00 & 139,46 & 0,00 \\
\hline \multirow{2}{*}{ Tempo de contrato (em dias) } & Anova $(\mathrm{F})$ & 93,97 & 0,00 & 83,28 & 0,00 \\
\hline & Kruskal-Wallis (Qui-Quadrado) & 148,62 & 0,00 & 352,12 & 0,00 \\
\hline
\end{tabular}

\section{II) Contratos finalizados}

Conforme destaca a literatura (Slyke, 2003, por exemplo), os contratos de serviços sociais apresentam mais chance de serem bem-sucedidos: (i) se a magnitude e a especificidade dos ativos envolvidos no fornecimento do serviço são menores; (ii) se as características qualitativas dos serviços forem menos expressivas; (iii) se há maior disponibilidade de competidores atuais ou potenciais no mercado e, principalmente; e (iv) se há controle e monitoramento da contratualização.

Desta maneira, esta seção demonstra os aspectos gerais dos contratos finalizados entre os convenentes e o governo central.

As Ilustrações 12, 13 e 14 evidenciam o comportamento médio do indicador de repasse para as cohorts de contratos finalizados por tipo de organização convenente.

Por meiodo gráfico da Ilustração 12, é possível perceber que os contratos pertencentes às cohorts de 2011 e 2012 obtiveram o menor repasse de recursos do governo central para o período estudado (média geral iguais a 0,43 e 0,31 , respectivamente).

Destaca-se que para geração de 2011, os contratos firmados com os entes federados apresentaram índice de repasse menor ou igual à média geral dos contratos finalizados (estados e distrito federal, 0,43; municípios, 0,23), sugerindo que os entes da federação são mais penalizados no repasse, quando comparados com as entidades privadas.

As Ilustrações 13 e 14 permitem ainda visualizar que a média geral do indicador de repasse para todas as cohorts das políticas de economia solidária $(0,74)$ é maior que a média geral das cohorts das políticas de emprego $(0,48)$. Esse resultado evidencia que as políticas de emprego foram mais afetadas, no período estudado, pelo contingenciamento federal. 
Esse resultado já tinha sido sugerido quando da análise das estatísticas das variáveis valor conveniado e valor liberado (Tabela 6), utilizadas para o cálculodo indicador de repasse. A crise fiscal brasileira (que se agravou entre 2013 e 2014) e os indicadores de desemprego podem estar relacionados a esses resultados.

O endividamento do governo central somado aos elevados índices de desemprego pode ter contribuído para que o repasse dos recursos existentes tenham sido priorizados para os programas de economia solidária, que são uma fonte de renda alternativa ao emprego formal.

As Ilustrações 12, 13 e 14 evidenciam ainda que as entidades privadas sem fins lucrativos quase sempre apresentam índice de repasse superior à média geral, ratificando que esse tipo de organização é o convenente menos afetado pelo contingenciamento do governo central, inclusive em períodos de crise. Salienta-se que esse resultado persistenas duas políticas estudadas (emprego e economia solidária). 
Ilustração 12: Evolução do comportamento médio do indicador de repasse por tipo de convenente e por cohort, total dos contratos

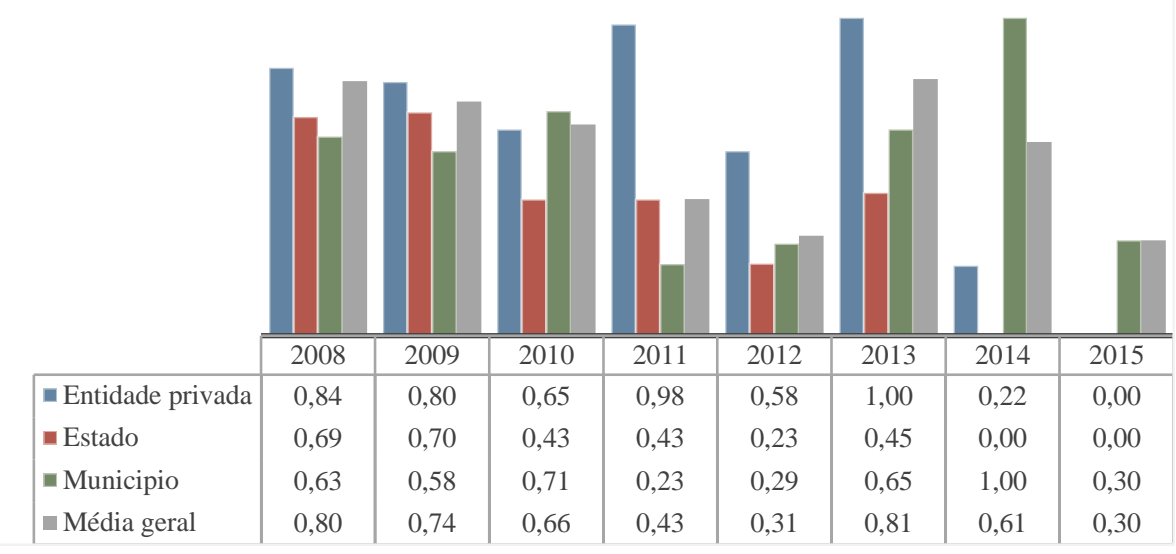

Ilustração 13: Evolução do comportamento médio do indicador de repasse por tipo de convenente e por cohort, emprego

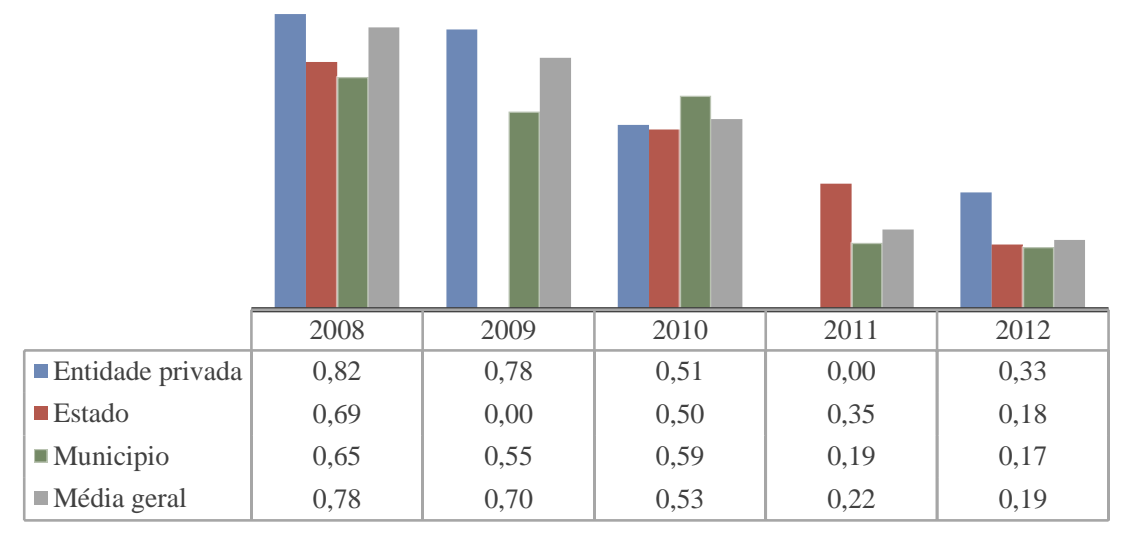

Ilustração 14: Evolução do comportamento médio do indicador de repasse por tipo de convenente e por cohort, economia solidária

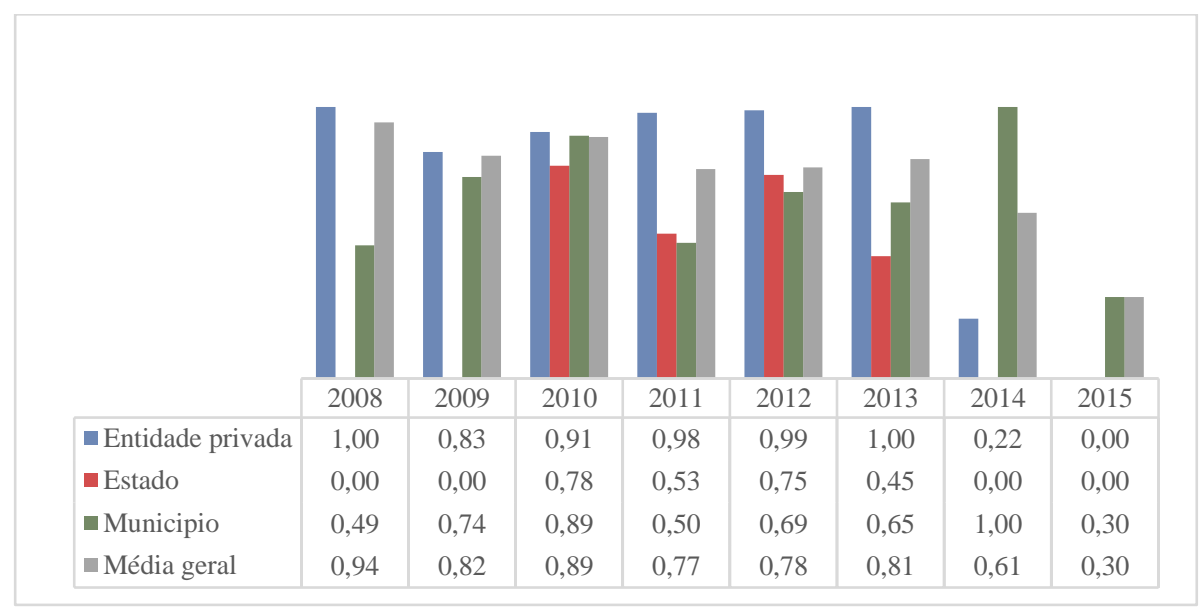


As Ilustrações 15, 16 e 17 evidenciam o comportamento médio do indicador de repasse para as cohorts de contratos finalizados por grau de cumprimento do contrato.

Ilustração 15: Evolução do comportamento médio do indicador de repassepor grau de cumprimento e por cohort, total dos contratos

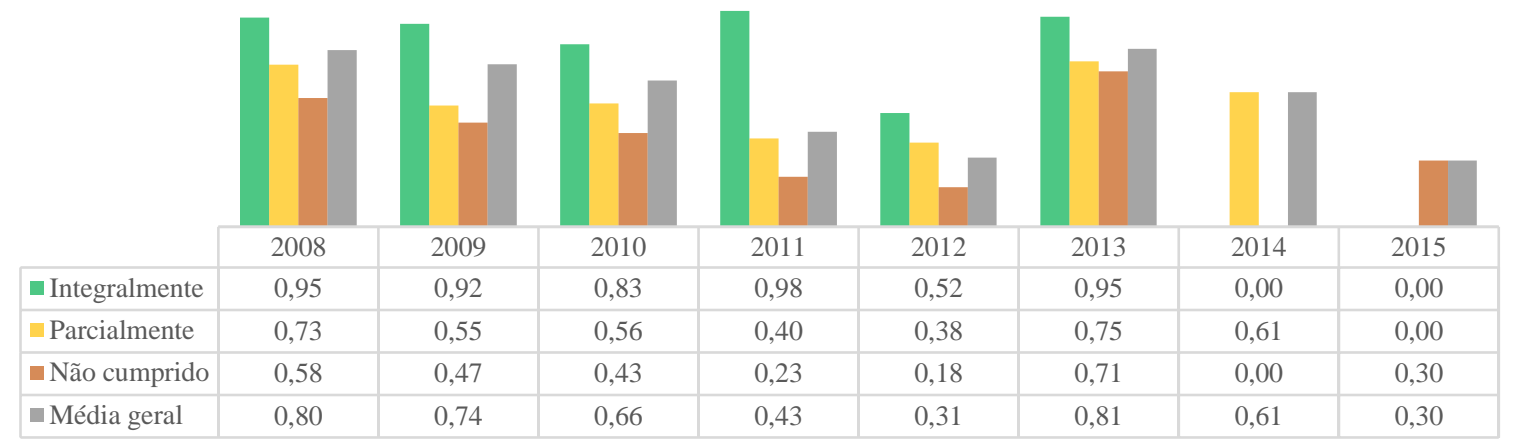

Ilustração 16: Evolução do comportamento médio do indicador de repasse por grau de cumprimento e por cohort, emprego

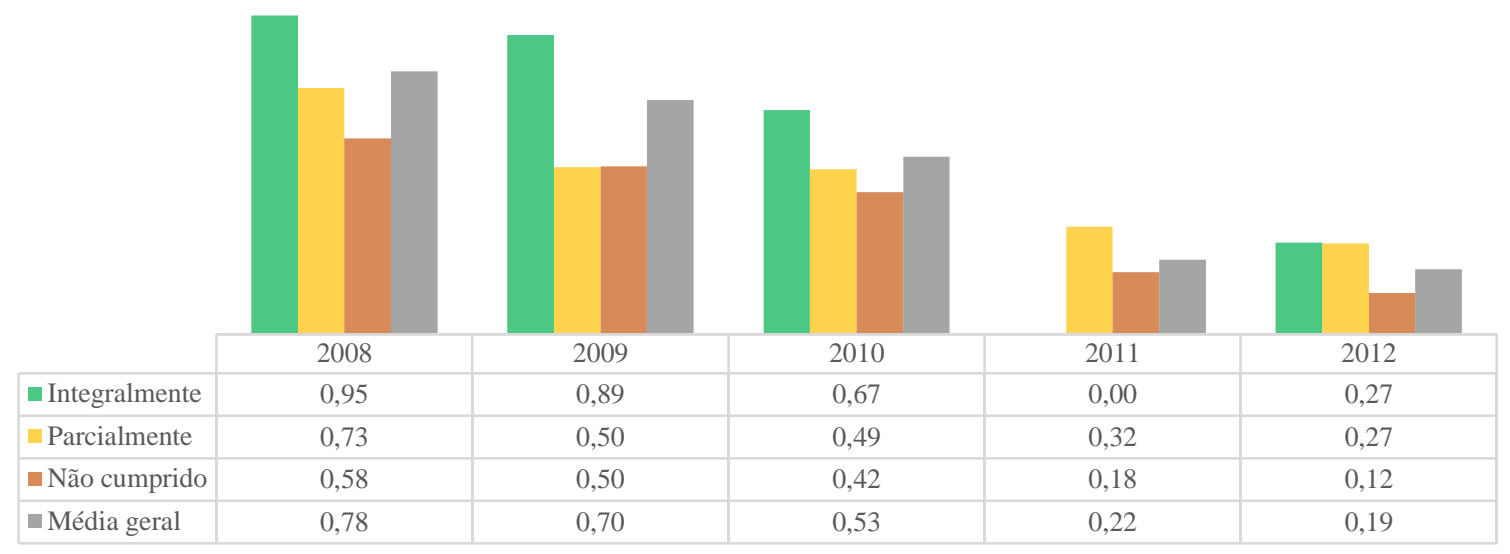

Ilustração 17: Evolução do comportamento médio do indicador de repasse por grau de cumprimento e por cohort, economia solidária

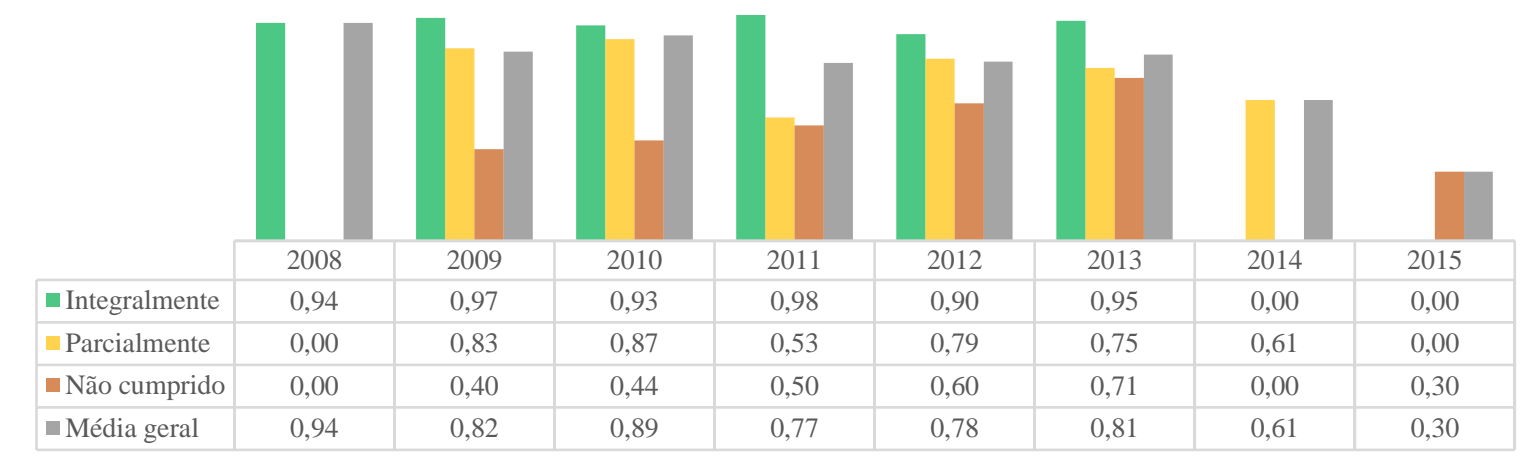


Os gráficos das Ilustrações 15, 16 e 17 revelam que entre os contratos analisados, aqueles cumpridos integralmente, obtiveram maior indicador de repasse de recursos. Esse resultado sugere que o cumprimento do contrato está relacionado com o indicador de repasse, o que de certa maneira corrobora com a literatura, que aponta a dependência dos convenentes dos recursos federais para a implementação de políticas públicas (Ilustração 15).

Para as políticas de emprego, o grau de cumprimento do contrato parece estar relacionado com o indicador de repasse (Ilustração 16). Para os contratos pertencentes às cohorts disponíveis, o indicador de repasse médio para os contratos cumpridos integralmente foi $\mathbf{0 , 5 6}(2008=0,95$ | $2009=0,89|2010=0,67| 2011=0,00 \mid 2012=0,27$ ), para os contratos cumpridos parcialmente foi $\mathbf{0 , 4 6}(2008=0,73|2009=0,50| 2010=0,49|2011=0,32| 2012=0,27))$ e para os contratos não cumpridos foi $\mathbf{0 , 3 6}(2008=0,58|2009=0,50| 2010=0,42|2011=0,18| 2012=0,19)$.

Resultado similar foi encontrado para as políticas de economia solidária (Ilustração 17). Assim, a média do indicador de repasse para os contratos cumpridos integralmente foi $\mathbf{0 , 7 0}$ (2008 = $0,95|2009=0,89| 2010=0,67|2011=0,98| 2012=0,90|2013=0,95| 2014=0,00 \mid 2015$ $=0,00)$, para os cumpridos parcialmente foi $\mathbf{0 , 5 4}(2008=0,00|2009=0,83| 2010=0,87 \mid$ $2011=0,53|2012=0,79| 2013=0,75|2014=0,61| 2015=0,00)$ e para os contratos não cumpridos foi $\mathbf{0 , 3 6}(2008=0,00|2009=0,40| 2010=0,44|2011=0,50| 2012=0,60 \mid 2013$ $=0,71|2014=0,00| 2015=0,30)$.

As Tabelas 8 e 9 (Apêndice C) sumarizam asinformações referentes às principais características dos contratos finalizados e suas cohorts. A maior parte dos contratos finalizados foi integralmente cumprida $(43,2 \%)$, e o percentual médio de cumprimento integral dos contratos concentra-se entre as cohorts 2008-2010, cuja média percentual é 50,7\% enquanto que a média de cumprimento integral para as outras cohorts totaliza $16 \%$.

A Tabela 8 indica que há aumento médio percentual de não cumprimento de contratos para as cohorts mais recentes, ou seja, entre o período de 2011-2015. O percentual médio de não cumprimento aumenta de 22,8\% (2008-2010) para 49\% (2011-2015), fator que pode ter acontecido em virtude dos menores valores de indicadores de repasse apresentados pelas cohorts de contratos mais recentes (conforme também demonstraram as Ilustrações 15, 16 e 17).

Ainda foram construídas, junto com as estatísticas descritivas uni e bivariadas, análises por meio da utilização de técnicas exploratórias de análise fatorial e análise de correspondência, 
com o intuito de elaborar rankings, grupos e, posteriormente, mapas perceptuais. Acredita-se que esse tipo de apresentação facilita a visualização do comportamento dos dados.

A técnica de análise de correspondência múltipla foi utilizada com o objetivo de construir mapas perceptuais que evidenciem visualmente as relações entre os grupos formados por meio do indicador de repasse, o grau de cumprimento dos contratos e os tipos de organizações dos convenentes, considerando o total de contratos e os contratos por política.

Já a técnica de análise fatorial por componentes principais foi utilizada com o objetivo de construir rankings de contratos que, posteriormente, foram insumos para elaboração dos grupos de contratos que estabeleceram metas altas, médias e baixas. Portanto, o ranking obtido foi baseado nas metas estabelecidas nos planos de trabalho dos contratos finalizados. Após o estabelecimento dos rankings e da elaboração dos grupos, também foram elaborados mapas perceptuais que demonstrassem a relação entre os grupos de metas, o grau de cumprimento dos contratos e as escolhas institucionais.

Primeiramente, serão apresentados os mapas perceptuais dos contratos finalizados considerando os grupos elaborados por meio do indicador de repasse. $\mathrm{O}$ indicador de repasse, conforme apresentado no capítulo de Método, é calculado por meio da relação entre valor liberado e valor conveniado, o que faz com que essa variável contenha valores entre 0 e 1 .

Dessa maneira, quanto menor a relação, menor o repasse realizado pelo governo central para o cumprimento do plano de trabalho estabelecido. Portanto, foram criados 3 grupos considerando os seguintes critérios: indicador de repasse menor ou igual a 0,5, repasse parcial e baixo; indicador maior que 0,5 e menor que 1 , repasse parcial e médio e; finalmente, indicador igual a 1, repasse total. Essa divisão foi realizada por conveniência e critério desta Autora ${ }^{13}$.

Os resultados da análise de correspondência múltipla estão evidenciados no Apêndice C (Tabelas 10, 11 e 12). Os mapas, que representam as relações entre os grupos construídos a partir do indicador de repasse, o grau de cumprimento do contrato (integralmente, parcialmente e não cumprido) e o tipo de organização (entidade privada, estado e município), para o total dos contratos finalizados, para os contratos de emprego e os de economia solidária estão apresentados na Ilustração 18.

\footnotetext{
13 É importante destacar que outros pontos de corte do indicador de repasse foram construídos e os mapas perceptuais obtidos foram bastante semelhantes.
} 
Ilustração 18: Mapas perceptuais, geral e por políticas públicas

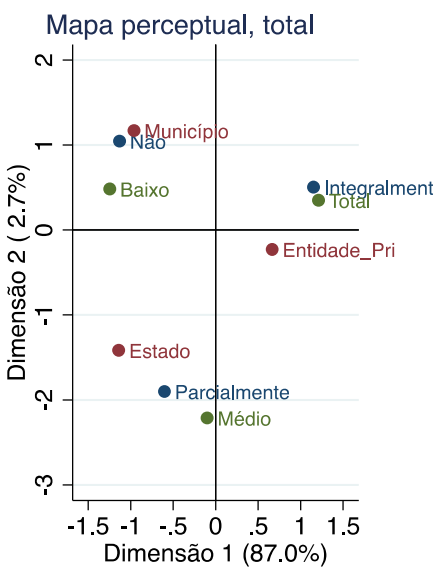

- grau de cumprimento

- escolha institucional

- grupos (indicador de repasse)

Mapa perceptual, SPPE

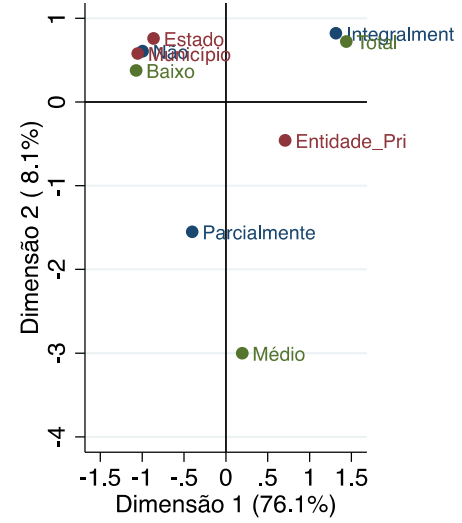

- grau de cumprimento

- escolha institucional

- grupos (indicador de repasse)

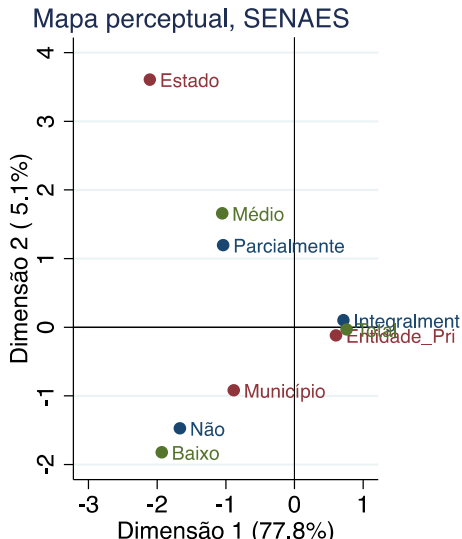

- grau de cumprimento

- escolha institucional

- grupos (indicador de repasse) 
Analisando os mapas perceptuais, verifica-se que há associações fortes entre o grau de cumprimento do contrato, os grupos do indicador de repasse e a escolha institucional (Ilustração $18)$.

Considerando o mapa perceptual que contempla a totalidade dos contratos (Ilustração 18) finalizados, é possível observar que há associação forte entre entidade privada, repasse total de recursos e o cumprimento integral dos objetivos estabelecidos no contrato; assim como há uma associação intensa entre municípios, repasse parcial baixo e o não cumprimento dos objetivos do contrato e parece haver também associação considerável entre estado, repasse parcial médio de recursos e cumprimento parcial dos objetivos estabelecidos no contrato.

Dessa maneira, a Ilustração18 revela que os contratos com os municípios foram os mais afetados pelo contingenciamento de recursos do governo central e isso, provavelmente, refletiu no não cumprimento dos objetivos estabelecidos nesses instrumentos. Destaca-se que, conforme afirma a literatura de transferências voluntárias, os municípios são financeiramente dependentes dos repasses da União para a implementação de uma série de políticas públicas em nível local, e um nível de repasse aquém do previsto reflete na execução dos planos de trabalhos estabelecidos.

Ao analisar o mapa perceptual das políticas públicas de emprego (Ilustração 18), monitoradas pela SPPE, verifica-se que há forte associação entre baixo repasse de recursos do governo central, o não cumprimento dos objetivos do contrato e os estados e os municípios. Isso revela que o maior contingenciamento de recursos está associado ao não cumprimento do contrato e que isso afeta mais fortemente os entes federados, levantando questionamentos sobre a cooperação financeira na qual, em essência, baseia-se o pacto federativo.

O mapa perceptual referente às políticas de economia solidária (Ilustração 18), monitoradas pela Senaes, demonstra que há uma associação forte entre repasse integral de recursos pelo governo central, entidades privadas sem fins lucrativos e o cumprimento integral dos contratos. Isso evidencia que tais entidades privadas sofrem menos com o contingenciamento de recursos do governo central e corrobora com a literatura de avaliação da economia solidária de que as entidades de direito privado são mais exitosas em implementar políticas públicas de economia solidária; ressalta-se que parte desse sucesso na execução das metas pode estar relacionado ao recebimento integral dos valores contratados. 
A seguir, serão apresentados os mapas perceptuais elaborados para análise visual das relações entre os grupos de metas, o grau de cumprimento dos contratos e as escolhas institucionais.

Para a construção desses grupos, foram primeiramente realizadas análises fatoriais por componentes principais, uma vez que as variáveis que compõem as metas contratuais são diversas e métricas e era necessário que a informação contida em cada uma delas estivesse presente em um número menor de variáveis, para confecção de um ranking.

A análise fatorial por componentes principais para as políticas públicas de emprego, monitoradas pela SPPE, teve como insumo quatro variáveis, coletadas em cada um dos planos de trabalho dos contratos finalizados: intermediação de mão de obra, qualificação profissional, seguro-desemprego e serviços em geral. Destaca-se que, conforme evidenciado no Apêndice A (Ilustração 10), essas variáveis foram mensuradas em número de beneficiários.

O resultado da análise fatorial também retornou dois fatores (autovalores maiores ou iguais a 1), conforme pode ser visto no Apêndice C (Tabela 13). Após a extração desses fatores, foi criada uma nova variável, chamada fator conjunto. Para isso, foi utilizado o critério da soma ponderada e ordenamento, em que uma nova variável é gerada a partir da multiplicação dos valores de cada fator pelos respectivos percentuais de variância compartilhada.

Após o ranking do fator conjunto, foram criados três grupos com bases nos seguintes valores, por conveniência desta Autora:fator conjunto com valores inferiores ou iguais a zero foram classificados no grupo metas físicas baixas; valores de fatores conjuntos entre 0 e 1 foram classificados no grupo metas físicas médias e; finalmente, valores de fatores conjuntosmaiores que 1 foram classificados no grupometas físicas altas.

É importante salientar que, apesar de o critério de classificação dos fatores em grupos ter sido por conveniência, foi levado em consideraçãoa magnitude e os "saltos" existentesnos valores dos fatores calculados para amostra.

Após a construção dos grupos de metas a partir dos critérios supracitados, foram desenvolvidos mapas perceptuais considerando a relação entre os grupos de metas, o grau de cumprimento do contrato e a escolha institucional, conforme demonstra a Ilustração19: 
Ilustração 19: Mapas perceptuais - SPPE

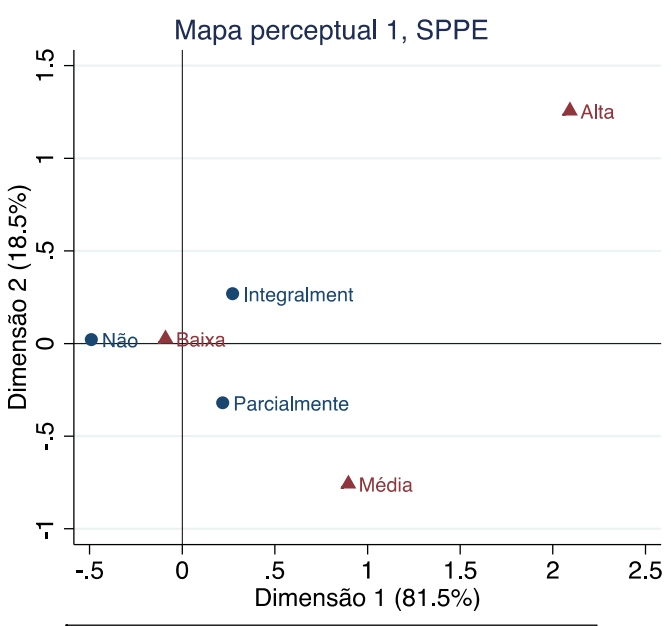

- grau de cumprimento $\Delta$ grupos (metas)

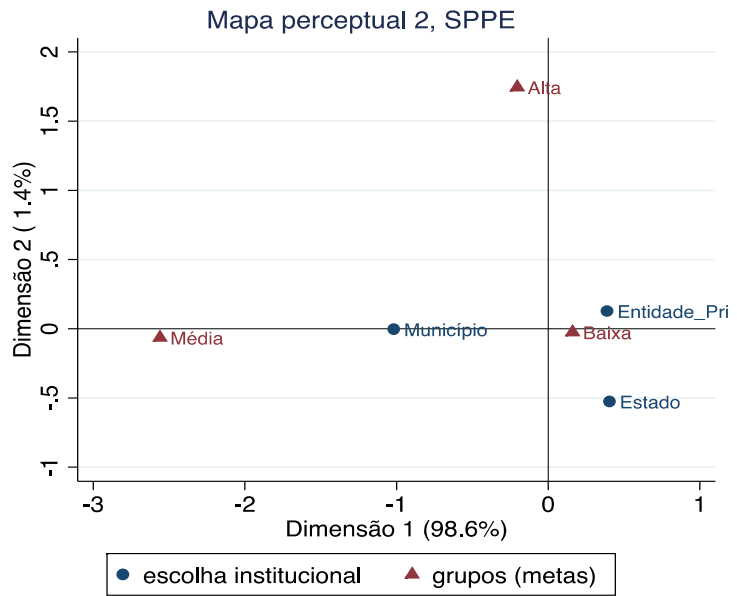

Mapa perceptual 3, SPPE

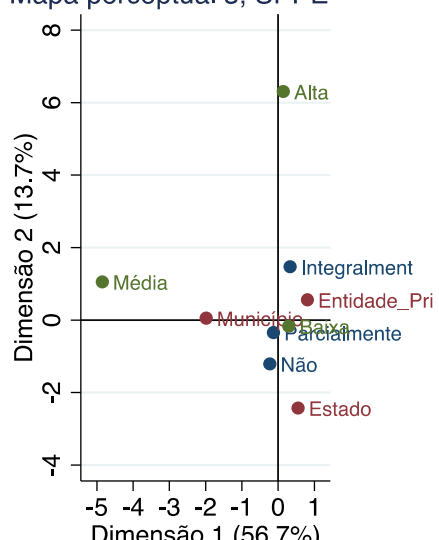

- grau de cumprimento

- escolha institucional

grupos (metas) 
No Apêndice C estão evidenciados os outputs das análises de correspondência simples e múltipla realizadas (Tabelas 14, 15 e 16). É importante ressaltar que, para a construção do mapa perceptual relacionado à MCA (mapa 3), os valores de associação não retornaram estatisticamente significante para a relação grau de cumprimento do contrato e grupo de metas.

A Ilustração 19 revela que, para os contratos finalizados e monitorados pela SPPE, existe uma forte associação entre o grupo de metas físicas baixas e o grupo de entidades privadas (mapa 2). Nesse sentido, para os contratos da SPPE, tanto as entidades privadas quanto municípios estabelecem metas físicas baixas (mapa 3), apesar de as entidades privadas conseguirem, ao contrário dos municípios, ter uma associação mais forte com o cumprimento dos contratos.

Os mapas perceptuais para análise visual das relações entre os grupos de metas, o grau de cumprimento dos contratos e as escolhas institucionais também foram elaborados para os contratosde políticas de economia solidária. E, de maneira similar, foram utilizadas análises fatoriais para o estabelecimento dos grupos de metas com base no ranking dos fatores.

A análise fatorial por componentes principais para as políticas públicas de economia solidária teve como insumo quatro variáveis, coletadas em cada um dos planos de trabalho dos contratos finalizados: quantidade de empreendimentos econômicos solidários (EES) assessorados, quantidade de EES estruturados, quantidade de bancos comunitários (BC) assessorados e quantidade de BC estruturados.

O resultado da análise fatorial retornou dois fatores (autovalores maiores ou iguais a 1), conforme pode ser visto no Apêndice C (Tabela 17). Após a extração desses fatores, foi criada uma nova variável, também chamada fator conjunto. Para isso, foi utilizado o mesmo critério da soma ponderada e ordenamento, utilizado anteriormente para as políticas de emprego.

Após o ranking do fator conjunto, foram criados também três grupos com bases nos mesmos critérios utilizados anteriormente, levando em consideração a magnitude e os "saltos" existentes nos valores dos fatores calculados para amostra: fator conjunto com valores inferiores ou iguais a zero foram classificados no grupo metas físicas baixas; valores de fatores conjuntos entre $0 \mathrm{e}$ 1 foram classificados no grupo metas físicas médias; e finalmente, valores de fatores conjuntos maiores que 1 foram classificados no grupo metas físicas altas.

Os dados de saída das análises de correspondência simples e múltipla realizadas estão contidos no Apêndice C (Tabelas 18, 19 e 20).As associações evidenciadasnos mapas 1 e 2 (Ilustração 20) são, portanto, aleatórias e a única associação significativa em termos estatísticos é entre 
grau de cumprimento do contrato e escolha institucional que, por sua vez, já tinha sido evidenciada em mapas anteriores. 
Ilustração 20: Mapas perceptuais - Senaes
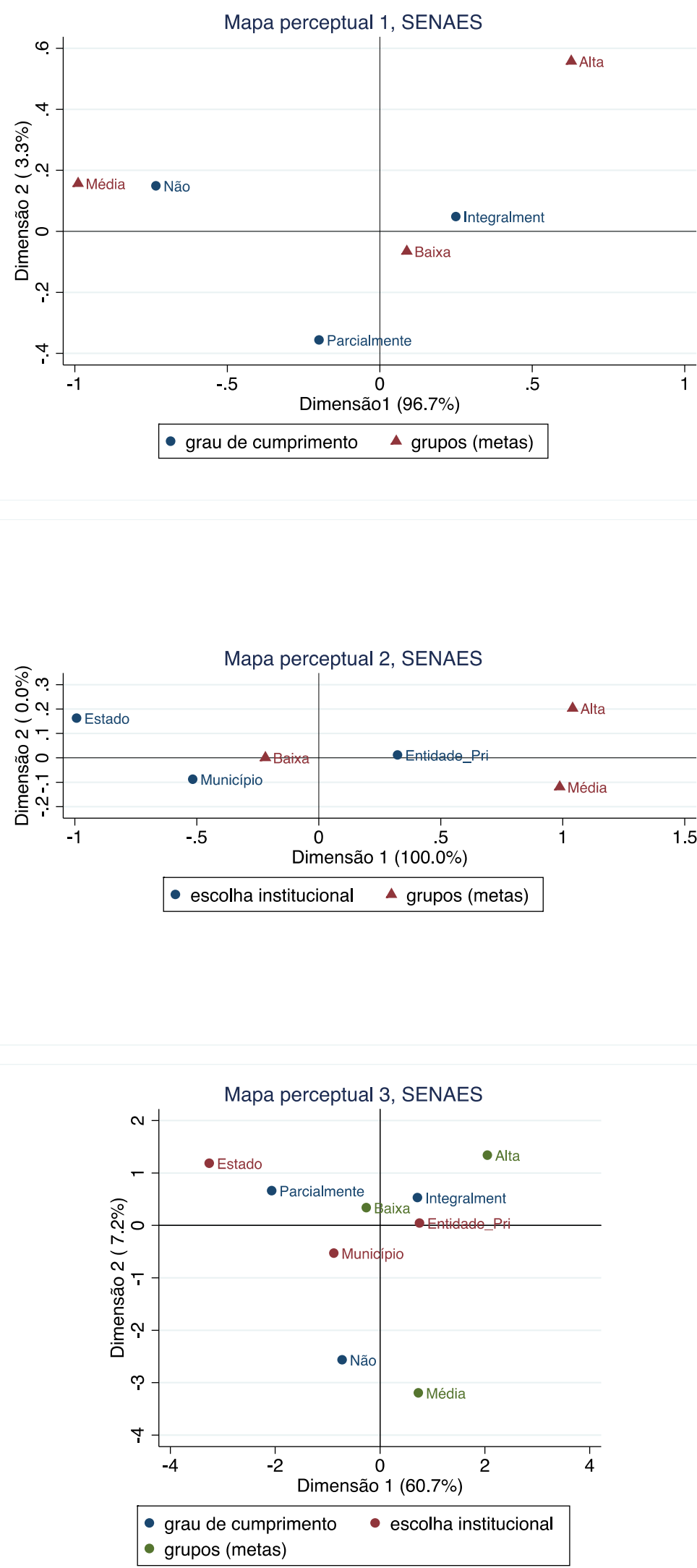
Em termos empíricos, esse resultado demonstra que, para as políticas públicas de economia solidária, os diferentes convenentes aparentemente não divergem ao definirem metas contratuais. Assim, as metas estabelecidas por eles não parecem influenciar o grau de cumprimento do contrato.

O critério para estabelecer os grupos de metas por meio do ranking dos fatores conjuntos foi idêntico para as duas políticas públicas estudadas(políticas de emprego e de economia solidária). Mesmo assim, o fato de os grupos terem sido construídos com base em critérios subjetivos considerando a magnitude dos valores (critério adotado por conveniência do pesquisador) faz com que os mapas perceptuais apresentados sejam alvo de questionamentos.

No entanto, entende-se que o fato de critérios idênticos para a classificação dos contratos em grupos terem evidenciado associações fortes em uma política e, aleatórias em outra, é um resultado interessante.

A divergência encontrada chama a atenção para a necessidade de se aprofundarna forma com que os convenentes elaboram suas metas, no momento do planejamento do plano de trabalho, antes de firmar o convênio e, assim, implementar cada uma das políticas. Ainda, ressalta a necessidade de se entender, em profundidade, quais critérios a SPPE e Senaes adotam ao analisarem e aprovarem os planos de metas apresentados.

Por fim, são apresentados os mapas perceptuais considerando a associação conjunta entre grupos de metas, grupos de indicadores, grau de cumprimento do contrato e escolha institucional, para as políticas de emprego e para as políticas de economia solidária. Os outputs das análises de correspondência, igualmente, estão no Apêndice C. A Ilustração21 contém os mapas perceptuais. 
Ilustração 21: Mapas perceptuais completos - SPPE e Senaes

Mapa perceptual 1, SPPE (completo)

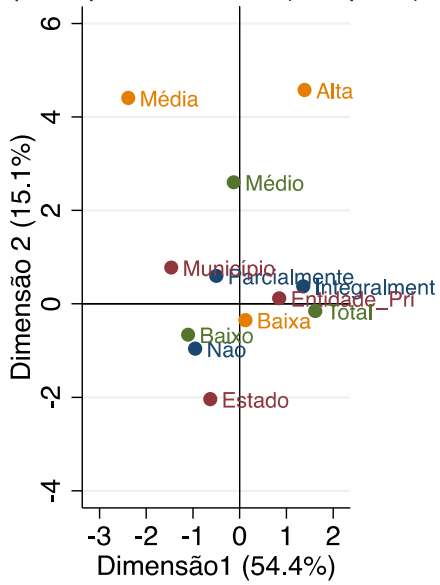

- grau de cumprimento escolha institucional

- grupos (indicador de repasse) grupos (metas)

Mapa perceptual 2, SENAES (completo)

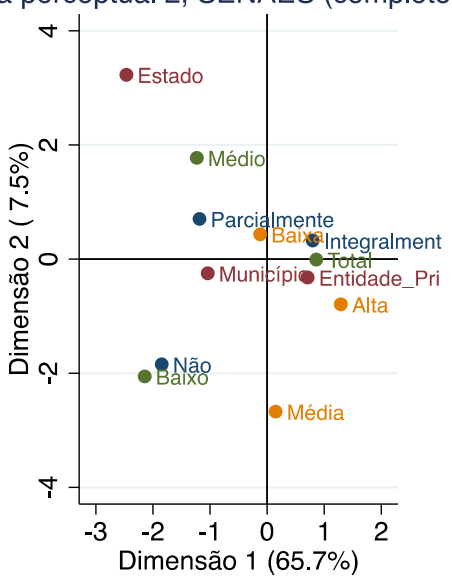

- grau de cumprimento

- escolha institucional

- grupos (indicadores de repasse)

- grupos (metas) 
A Ilustração 21 (mapas 1 e 2) evidencia as associações entre as quatro variáveis analisadas nesta seção: grau de cumprimento do contrato, escolha institucional, grupos de indicadores e grupos de metas.

Assim, os resultados das MCA (Tabelas 21 e 22 - Apêndice C) demonstram que há uma associação forte entre os grupos de metas físicas baixas e os grupos de indicadores de repasse baixo e alto. Esse resultado sugere que para as políticas de emprego, o estabelecimento de metas físicas baixas é uma realidade tanto nos contratos que receberam menos recursos do governo central quanto naqueles que receberam o total de recursos solicitados.

O mapa 1 (Ilustração 21) complementa esse achado, indicando que entidades privadas cumprem integralmente seus contratos, recebem o total de recursos previamente estabelecidos nos convênios e parecemelaborarplanos de trabalho com metas físicas.

De maneira análoga às políticas de emprego, as entidades privadas que executam contratos vinculados à economia solidária também são menos prejudicadas pelo contingenciamento de recursos do governo central, apesar de não haver diferenças entre os tipos institucionais no que concerne ao estabelecimento de metas físicas (mapa 2 da Ilustração 21, Tabelas 23 e 24 Apêndice C). Uma possível explicação para isso pode ser devido ao fato de as políticas de economia solidária serem mais recentes no país e sofrerem em menor grau, ainda, a influência de fatores político-partidários.

Esse resultado indica que há características nas organizações e nas suas relações entre agente e principal podem contribuir para as diferenças entre os planos de trabalho e os resultados obtidos, justificando o uso de modelos hierárquicos para análises do objetivo da pesquisa.

\subsection{Information values (IV)}

Nas seções anteriores, foi comentado que os contratos possuem características cadastrais, de metas, de execução e de prestação de contas próprios. Adicionalmente, foi demonstrado que os graus de cumprimento dos contratos parecem estarassociadosdiferentemente com os tipos de convenentes, muito provavelmente em virtude das divergências entre suas escolhas institucionais e entre a sua relação de agênciacom o principal. 
Assim, considerando que as escolhas institucionais e a relação de agência influenciam a execução dos contratos (hipótese da pesquisa), é relevante mapear, inicialmente, quais características (cadastrais, de execução e de prestação de contas) contratuais têm maior poder de segregar, entre os contratos finalizados, os que foram cumpridos (integralmente e parcialmente) dos que não foram cumpridos (não cumpridos).

É interessante, ainda, segregar, entre os contratos cumpridos, as características contratuais qualitativas que têm o poder de segregar aqueles cumpridos integralmente daqueles cumpridos parcialmente.

Para isso, foram utilizadas variáveis categóricas para o cálculo dos $I V \mathrm{~s}$. A Tabela 25 evidencia os valores dos $I V$ s obtidos. Variáveis com valores de IV superiores a 0,2 possuem médio/alto poder para discriminar eventos e não eventos, conforme descrito no capítulo 3, Método.Na Tabela 11, estão marcadas as variáveis que apresentaram $I V$ s maiores que 0.3 , valor que caracteriza uma variável com alto poder de discriminar eventos e não eventos.

Primeiramente, serão analisadas as variáveis que possuem o maior $I V$ entre os contratos cumpridos e não cumpridos. Há variáveis discriminatórias classificadas em duas categorias de variáveis: execução e prestação de contas. Na categoria execução, as variáveis que mais segregam contratos cumpridos de não cumpridos é a existência de subcontratos, de pelo menos uma mudança no plano de trabalho e de pedido de remanejamento de recursos.

$\mathrm{Na}$ categoria prestação de contas, os maiores $I V$ s foram obtidos para entrega de relatórios financeiros, de pagamentos, de documentos, de receitas e despesa, de serviços e físicos. Destaca-se que o fato de esses relatórios terem sido rejeitados pelo menos uma vez também ajuda a segregar os contratos cumpridos dos contratos não cumpridos.

Ao se analisar as categorias de variáveis que separam contratos cumpridos integralmente dos cumpridos parcialmente, verifica-se a secretaria que monitora os contratos. Destaca-se que mudanças relacionadas ao cronograma de desembolso e a existência de um parecer técnico possuem poder discriminatório médio. 
Tabela 25: Information value (IV) das variáveis qualitativas

\begin{tabular}{|c|c|c|c|c|c|}
\hline Variáveis/Categorias & $\begin{array}{l}\text { Integral versus } \\
\text { parcial } \\
\text { (cumpridores) }\end{array}$ & $\begin{array}{l}\text { Cumpridores versus } \\
\text { não cumpridores } \\
\text { (cumprimento) }\end{array}$ & Variáveis/Categorias & $\begin{array}{l}\text { Integral versus } \\
\text { parcial } \\
\text { (cumpridores) }\end{array}$ & $\begin{array}{c}\text { Cumpridores versus } \\
\text { não cumpridores } \\
\text { (cumprimento) }\end{array}$ \\
\hline Cadastro & & & Prestação de Contas & & \\
\hline Projeto & 0,00 & 0,03 & Devolução de recursos & 0,02 & 0,49 \\
\hline Emenda & 0,00 & 0,01 & Pareceres & & \\
\hline Tipo de direito & 0,12 & 0,11 & $\begin{array}{l}\text { Estorno de } \\
\text { Inadimplência }\end{array}$ & 0,00 & 0,00 \\
\hline Secretaria & 0,32 & 0,12 & Aprovação & 0,20 & 0,01 \\
\hline Tema & & & Financeiro & 0,16 & 0,21 \\
\hline Economia Solidária & 0,03 & 0,12 & Rejeição & 0,03 & 0,01 \\
\hline Microcrédito & 0,02 & 0,02 & Resgate & 0,00 & 0,00 \\
\hline Qualificação & 0,00 & 0,18 & Ressalvas & 0,00 & 0,16 \\
\hline Sine & 0,00 & 0,02 & Retificação & 0,01 & 0,02 \\
\hline Execução & & & Técnico & 0,26 & 0,92 \\
\hline $\begin{array}{l}\text { Pelo menos uma mudança } \\
\text { contratual }\end{array}$ & 0,07 & 0,74 & Geral & 0,06 & 0,36 \\
\hline Cronograma físico & 0,04 & 0,28 & Publicações & 0,00 & 0,07 \\
\hline $\begin{array}{l}\text { Cronograma de } \\
\text { desembolso }\end{array}$ & 0,25 & 0,23 & Relatórios de rejeição & & \\
\hline Metas & 0,00 & 0,00 & Beneficiários & 0,03 & 0,11 \\
\hline Outros & 0,00 & 0,00 & Bens adquiridos & 0,00 & 0,14 \\
\hline Contrapartida & 0,00 & 0,00 & Contrapartida & 0,07 & 0,10 \\
\hline Prazos (solicitação) & 0,02 & 0,12 & Bens construídos & 0,00 & 0,02 \\
\hline Plano de aplicação & 0,04 & 0,00 & Físico & 0,03 & 0,36 \\
\hline Remanejamento & 0,09 & 0,48 & Documentos & 0,07 & 0,52 \\
\hline Saldo remanescente & 0,00 & 0,00 & Financeiro & 0,06 & 0,60 \\
\hline Modificação no SICONV & 0,00 & 0,00 & Pagamentos & 0,07 & 0,65 \\
\hline Prorrogação de prazo & 0,09 & 0,33 & Receita e despesa & 0,05 & 0,52 \\
\hline Subcontratos & 0,01 & 1,85 & Serviços & 0,06 & 0,45 \\
\hline $\begin{array}{l}\text { Tipo de Gasto (com } \\
\text { recurso do convênio) }\end{array}$ & & & Entrega de Relatórios & & \\
\hline Bens & 0,09 & 0,21 & Beneficiários & 0,09 & 1,05 \\
\hline Despesa administrativa & 0,00 & 0,01 & Bens adquiridos & 0,00 & 0,90 \\
\hline Obras & 0,02 & 0,00 & Contrapartida & 0,06 & 0,65 \\
\hline Outros & 0,01 & 0,00 & Bens construídos & 0,00 & 0,08 \\
\hline Serviços & 0,00 & 0,00 & Físico & 0,01 & 2,24 \\
\hline Tributos & 0,07 & 0,01 & Documentos & 0,08 & 2,00 \\
\hline \multirow[t]{5}{*}{ Termos Aditivos } & 0,00 & 0,33 & Financeiro & 0,00 & 3,39 \\
\hline & & & Pagamentos & 0,00 & 2,68 \\
\hline & & & Receita e despesa & 0,00 & 1,40 \\
\hline & & & Serviços & 0,01 & 2,52 \\
\hline & & & $T C E$ & 0,00 & 0,00 \\
\hline
\end{tabular}


A análise dos valores dos IVs é uma análise bivariada que precede a construção de um modelo logístico. A Tabela 26, contida no Apêndice C, apresenta os valores das estatísticas de quiquadrado e p-valor dos testes de associação entre essas variáveis categóricas e o grau de cumprimento do contrato, bem como com o tipo de convenente.

Os resultados das estatísticas descritivas uni e bivariadas e das técnicas exploratórias são interessantes para evidenciar o comportamento dos dados, sobretudo das associações existentes entre as suas categorias.

Dessa maneira, os procedimentos estatísticos iniciais demonstraram indícios de que os contratos são implementados de formas diversas pelos diferentes tipos de organizações convenentes, e que isso pode decorrer da relação entre agente e o principal, uma vez que o repasse, a contratação de planos de trabalho com metas relativamente diferentes para um mesmo objetivo, por exemplo, divergem entre entidades privadas, estados e municípios, o que reforça a necessidade de uma análise multivariada confirmatória de tais relações.

Ainda, o fato de as variáveis relativas às escolhas institucionais apresentarem associação não aleatória com as de execução e prestação de contas dos contratos ressalta mais a necessidade da utilização de modelos multiníveis, uma vez que os contratos implementados são influenciados pelas escolhas institucionais dos diferentes tipos de organização e as relações entre agente e principal.

Assim, o uso de técnicas confirmatórias hierárquicas parece aplicável para realização de inferências sobre esses resultados iniciais. Os resultados dos modelos confirmatórios são apresentados nas próximas seções.

\subsection{Análise das técnicas confirmatórias: modelos hierárquicos e tradicionais}

Nesta seção serão apresentados os resultados dos modelos confirmatórios construídos na pesquisa. Para cada um dos modelos construídos, serão evidenciados a variável dependente (y), as variáveis independentes, os resultados obtidos e os testes necessários à análise. Adicionalmente, os modelos serão apresentados em etapas: modelo nulo (ou não condicional), que permite verificar se há variabilidade no cumprimento do contrato entre convenentes provenientes de organizaçõesdiferentes, modelo com interceptos aleatórios e, em alguns casos, modelo com interceptos e inclinações aleatórias. 
Caso a estimação hierárquica não seja apontada como a mais adequada pelos testes de especificação, serão utilizados os modelos tradicionais de regressão linear, regressão logística ou regressão para dados em contagem, a depender da natureza da variável dependente. Os resultados serão apresentados por hipótese a ser testada, as mesmas elencadas na Ilustração 11.

\section{HIPÓTESE DA PESQUISA: Alterações na relação entre valor liberado e valor conveniado (indicador de repasse) promovem alterações na forma como o contrato é executado e na sua prestação de contas.}

Os resultados apresentados nesta seção serão referentes aos modelos hierárquicos lineares cuja variável dependente (Y) é o indicador de repasse. O objetivo aqui é verificar como e quais características contatuais relacionam-se com a relação valor liberado/valor conveniado (indicador de repasse)para o convênio firmado.

Espera-se que haja uma relação significante para variáveis de cadastro, de execução e de prestação de contasporque a literatura sugere uma dependência em relação aos repasses federais para implementação de políticas públicas, especialmente as sociais, em nível local. Portanto, um repasse inferior de recursos pelo governo central pode influenciar nas características contratuais de uma maneira geral.

Primeiramente, serão apresentados os modelos com estimação hierárquica e seus testes de adequação. Caso seja necessário, serão apresentados os modelos estimados tradicionalmente. Após a verificação do melhor modelo de estimação, serão analisados os resultados obtidos. Os outputs completos dos modelos construídos estão evidenciados no Apêndice C.

\section{a) Totalidade dos contratos finalizados}

i) Modelo nulo

O modelo nulo foi estimado por REML considerando a escolha institucional (que contempla os tipos de organizações convenentes) como variável de nível 2. Os principais resultados estão evidenciados na Tabela 27: 
Tabela27: Modelo nulo (geral)

\begin{tabular}{|ccccc|}
\hline Nível 2 & ICC & Erro padrão & \multicolumn{2}{c|}{ Intervalo de confiança (95\%) } \\
\hline escolha & 0,15 & 0,13 & 0,02 & 0,58 \\
\hline & LR teste vs. modelo linear: chibar2 $(01)=35,37$ & Prob $>=$ chibar2 $=0,00$ \\
\hline
\end{tabular}

Os resultados do modelo nulo permitem verificar aproximadamente $15 \%$ do indicador de repasse é devido à alteração entre entidades privadas, estados e distrito federal e municípios, sugerindo existência de variabilidade de valor liberado para contratos provenientes de tipos de organizações diferentes. Destaca-se que, apesar de a Tabela 27 não demonstrar o valor do teste z com os respectivos níveis de confiança para os parâmetros, esse valor pode ser calculado dividindo-se o valor do parâmetro pelo seu erro padrão e consultando a Tabela z.

Para o modelo nulo em análise, o valor de ICC não é estatisticamente significante a $95 \%$ de confiança (o valor da estatística z obtida é aproximadamente 1,10 determinando um nível de confiança de, aproximadamente, $87 \%$ ).

Esse resultado indica que, a priori, não existe efeito entre os grupos e que, portanto, não há necessidade de modelagem multinível. Garson (2013), contudo, reitera que um ICC não significante (considerando um nível de $95 \%$ de confiança) não descarta a necessidade de um modelo de interceptos aleatórios, uma vez que o teste do ICC do modelo nulo testa somente as diferenças nos interceptos e não nos coeficientes das covariadas.

Em linha com a explicação de Garson (2013), o LR test sugere que o modelo multinível é preferível ao modelo tradicional, uma vez que o seu resultado rejeita a hipótese nula de que os interceptos são iguais. Portanto, para definir se o modelo final a ser analisado será multinível ou não, faz-se necessário ainda analisar os resultados dos modelos de interceptos aleatórios.

O modelo de interceptos aleatórios também foi estimado por REML considerando a escolha institucional como variável de nível 2. Os modelos de interceptos e inclinações aleatórios não convergiram. Os resultados obtidos para os modelos de interceptos aleatórios estão evidenciados na Tabela 28, e os outputs completos obtidos no Apêndice C (Tabela 29). 
ii) Modelo de interceptos aleatórios

Tabela28: Contratos finalizados (total)

\begin{tabular}{|lcc|}
\hline \multicolumn{1}{|c}{ Indicador de repasse } & Coeficiente & \\
\hline ind_projeto & $-0,11$ & $* * *$ \\
indbenscomrecursodoconvenio & 0,10 & $* * *$ \\
ind_devoluçãorecurso & 0,09 & $* * *$ \\
documentos_ind & $-0,06$ & $* *$ \\
financeiro_ind & 0,14 & $* * *$ \\
ind_subcontratos & 0,13 & $* * *$ \\
ind_prorrogação & 0,08 & $* *$ \\
indtributoscomrecursodoconve & $-0,11$ & $* * *$ \\
PT_prazo & $-0,08$ & $* *$ \\
indoutroscomrecursodoconveni & 0,08 & $* * *$ \\
quantidadededesembolsos & $-0,01$ & $* * *$ \\
quantidade_termosaditivos & 0,06 & $* * *$ \\
quantidade_prorrogações & 0,03 & $* * *$ \\
Parâmetros de efeitos aleatórios & & \\
var(_cons) & 0,00 & \\
var(Residual) & 0,05 & \\
ICC & 0,06 & \\
\hline LR test vs. modelo linear: chibar2(01) = 8,06 & Prob $>=$ chibar2 = 0,0023 \\
\hline Nível de Confiança: *** (99\%);*(95\%) & & \\
\end{tabular}

iii) Análise dos resultados do modelo

Os resultados da Tabela 28 evidenciaram que o modelo multinível é preferível ao modelo de regressão tradicional, uma vez que o p-valor do LR test é menor que 5\%, rejeitando a hipótese nula de que os interceptos aleatórios sejam iguais a zero.

O modelo de interceptos aleatórios retornou 13 variáveis significantes a 95\% de confiança. As variáveis indicadoras de projeto (ind_projeto), de relatório de documentos (documentos_ind), de gastos com tributos utilizando recursos do convênio (indtributoscomrecursodoconve) e de solicitação de alteração dos prazos do plano de trabalho (PT_prazo) apresentaram coeficiente negativo.

Esse resultado sugere que a existência dessas características de execução e de prestação de contas são menos encontradas em contratos os quais recebem maior repasse de recursos do governo central (maior indicador de repasse).

Ou seja, os contratos que possuem maiores indicadores de repasse tendem a não apresentarem pedidos de prorrogação de prazo para a execução do plano de trabalho e não apresentarem relatórios de documentos em suas prestações de contas. Adicionalmente, quanto maior o repasse 
feito para o contrato, maior a tendência desse contrato não gastar com tributos e não deixar disponível para consulta seus planos de trabalho.

A quantidade de desembolsos (quantidadededesembolsos) também apresentou relação significante e negativa com o indicador de repasses. Essa variável é mensurada pela quantidade de vezes que o convenente e o concedente deixaram, à disposição do contrato, os recursos financeiros. Esse resultado indica que quanto maior o volume de repasses financeiros, menor a quantidade de vezes que o desembolso foi realizado, sugerindo que os recursos são colocados à disposição para execução do contrato em menos quantidade de parcelas.

As variáveis indicadoras de gastos com bens (indbenscomrecursodoconvenio), de devolução de recursos (ind_devoluçãorecurso), de apresentação de relatórios financeiros (financeiro_ind), de existência de subcontratos (ind_subcontratos), de prorrogação de prazo (ind_prorrogação) e de outros gastos (indoutroscomrecursodoconveni) apresentaram coeficientes significantes e positivos com o indicador de repasse, ceteris paribus.

Esse resultado indica que para contratos com repasses maiores há indicativo de gastos com bens, indicando que o maior repasse está relacionado a gastos estruturais, representativos de despesas de capital.

Como consequência, os contratos que apresentam maiores indicadores de repasse tendem a apresentar relatórios financeiros e a firmarem subcontratos, situações que demonstram, de fato, a implementação dos objetivos estabelecidos em seus planos de trabalho.

Em relação ao indicador de prorrogação de prazo, uma observação se faz importante. O resultado indica que quanto maior o indicador de repasse, maior frequência de solicitações de prorrogação dos contratos. A princípio, esse resultado parece contraditório com o obtido em relação à solicitação de prazo para cumprimento do plano de trabalho, variável que foi analisada, nos parágrafos anteriores, por ter relação negativa e significante com o indicador de repasse.

Entretanto, as duas variáveis mensuram coisas distintas. A variável solicitação de prorrogação de prazo para a execução do plano de trabalho é mensurada por meio da solicitação, por parte do convenente, de prorrogação de prazo.

Já a variável indicador de prorrogação significa que a secretaria do governo central aprovou pelo menos uma prorrogação, por vontade própria ou em virtude de uma solicitação prévia do 
convenente. Portanto, nem toda prorrogação de prazo solicitada pelo convenente é concedida, assim como a prorrogação de prazo do contrato pode ter ocorrido por iniciativa da secretaria que monitora o contrato, sem necessariamente ter sido solicitada pelo convenente. Portanto, os resultados obtidos não são contraditórios.

A esse respeito, os resultados revelam que quanto maior o indicador de repasse do contrato, maior a quantidade de prorrogações (quantidade_prorrogações) e termos aditivos (quantidade_termosaditivos) verificados, bem como a incidência de devolução de recursos (ind_devoluçãorecurso), ceteris paribus.

Esse resultado chama atenção para a operacionalização dos contratos. Os achados indicam que a existência de recursos não necessariamente está ligada à tempestividade e à capacidade de execução dentro do prazo de vigência. Ou seja, o fato de o repasse ser feito, esbarra em questões operacionais, fazendo com que seja necessário prorrogar a vigência do convênio para que os objetivos estabelecidos nos planos de trabalho sejam concretizados.

Os resultados analisados referem-se à totalidade dos contratos finalizados da amostra. Nas próximas seções, serão apresentados os resultados dos modelos por secretaria, considerando as políticas de emprego e as de economia solidária.

\section{b) Contratos finalizados de políticas de emprego}

i) Modelo nulo

O modelo nulo foi estimado por REML considerando a escolha institucional como variável de nível 2. Os principais resultados estão evidenciados na Tabela 30:

Tabela 30: Modelo nulo (políticas de emprego)

\begin{tabular}{|ccccc|}
\hline Nível 2 & ICC & Erro padrão & Intervalo de confiança (95\%) \\
\hline escolha & 0,23 & 0,18 & 0,04 & 0,7 \\
\hline LR test vs. modelo linear: chibar2 $(01)=\mathbf{7 2 , 9 0}$ & Prob $>=$ chibar2 = 0,00 \\
\hline
\end{tabular}

Os resultados do modelo nulo indicam que aproximadamente $23 \%$ do indicador de repasse é devido à alteração entre os tipos de convenentes, sugerindo a existência de variabilidade de valor de repasse para contratos provenientes de instituições diferentes: entidades privadas, estado e distrito federal e municípios. A utilização de modelos hierárquicos é recomendada. A Tabela 31 evidencia os principais resultados obtidos e os outputs completos estão evidenciados no Apêndice C (Tabela 32). 
ii) Modelo de interceptos aleatórios

Tabela31: Contratos finalizados (políticas de emprego - SPPE)

\begin{tabular}{|lcc|}
\hline \multicolumn{1}{|c}{ Indicador de repasse } & Coeficiente & \\
\hline ind_projeto & $-0,13$ & $* * *$ \\
documentos_ind & $-0,09$ & $* * *$ \\
servicos_ind & 0,18 & $* * *$ \\
ind_subcontratos & 0,11 & $* * *$ \\
indtributoscomrecursodoconve & $-0,11$ & $* * *$ \\
pt_plano & 0,19 & $* * *$ \\
indoutroscomrecursodoconveni & 0,08 & $* * *$ \\
ind_parecer_retificação & 0,27 & $* *$ \\
quantidadededesembolsos & $-0,02$ & $* * *$ \\
quantidade_termosaditivos & 0,06 & $* * *$ \\
quantidade_prorrogações & 0,03 & $* * *$ \\
Parâmetros de efeitos aleatórios & & \\
var(_cons) & 0,01 & \\
var(Residual) & 0,06 & \\
ICC & 0,1 & \\
\hline LR test vs. modelo linear: chibar2(01) $=12,47$ & Prob >= chibar2 $2=0,0002$ & \\
\hline Nível de Confiança: *** (99\%); **(95\%) & & \\
\hline
\end{tabular}

iii) Análise dos resultados obtidos com o modelo de interceptos aleatórios

O modelo de interceptos aleatórios é preferível ao modelo de regressão tradicional, uma vez que o p-valor do LR test é menor que 5\%, rejeitando a hipótese nula de que os interceptos aleatórios sejam iguais a zero.

O resultado do modelo de interceptos aleatórios para as políticas de emprego, monitoradas pela SPPE, retornou como significante 11 variáveis, sendo 8 variáveis categóricas e 3 variáveis métricas (Tabela 31). As variáveis indicadoras de projeto (ind_projeto), relatório de documentos (documentos_ind) e gastos com tributos utilizando recursos do convênio (indtributoscomrecursodoconve) apresentaram coeficientes significantes e com sinal negativo, ceteris paribus.

Isso significa que para os contratos que receberam repasses maiores, não há indicativos de evidenciação de seus projetos (planos de trabalho, por exemplo), de apresentação de relatórios de documentos e de gastos com tributos. Destaca-se que este resultado também foi observado para o modelo que continha todos os contratos da amostra. 
Já as variáveis indicadoras de relatório de serviços (servicos_ind), de mudanças no plano de trabalho (PT_plano) e de parecer de retificação (ind_parecer_retificação) apresentaram coeficientes significantes e positivos. Esses resultados indicam que para os contratos que receberam maiores repasses, há indicativosde apresentação de relatórios de serviços, de pareceres de retificação por parte da concedente e de pelo menos uma mudança referente à forma de executar o contrato firmado. Importante salientar que essas três variáveis se mostraram significantes somente para as políticas de emprego, monitoradas pela SPPE.

Ainda, as variáveis métricas quantidade de desembolsos (quantidadededesembolsos), quantidade de prorrogações (quantidade_prorrogações) e quantidade de termos aditivos (quantidade_termosaditivos) apresentaram coeficientes positivos e significantes no modelo de interceptos aleatórios, indicando que quanto maior o repasse recebido do governo central pelo convenente, maior as quantidades de prorrogações, de termos aditivos e de desembolsos verificados nos contratos de emprego, ceteris paribus.

Os resultados das variáveis quantidade de prorrogações e de termos aditivos verificados para as políticas de emprego são consistentes com os obtidos para o modelo geral. Isto é, os convenentes que possuem mais recursos à sua disposição geralmente precisam e obtêm mais prazo para implementar o contrato firmado.

No entanto, diferentemente do modelo geral, para as políticas públicas de emprego, a quantidade de desembolsos é diretamente proporcional ao indicador de repasse, indicando que nesses contratos, quanto maior o repasse, maior a quantidade de parcelas (do ponto de vista de fluxos de caixa) necessárias para deixar o recurso disponível para o contrato.

\section{c) Contratos finalizados de políticas de economia solidária}

i) Modelo nulo

O modelo nulo foi estimado por REML considerando a escolha institucional como variável de nível 2. Os principais resultados estão evidenciados na Tabela 33:

Tabela 33: Modelo nulo (políticas de economia solidária)

\begin{tabular}{|llccc|}
\hline Nível 2 & ICC & Erro padrão & \multicolumn{2}{c|}{ Intervalo de confiança (95\%) } \\
\hline escolha & 0,19 & 0,18 & 0,02 & 0,69 \\
\hline \multicolumn{4}{|c|}{ LR test vs. modelo linear: chibar2 $(\mathbf{0 1})=\mathbf{1 3 , 4 9}$} & Prob >= chibar2 = 0,0001 \\
\hline
\end{tabular}


Os resultados do modelo nulo indicam que aproximadamente 19\% do indicador de repasse é devido aos diferentes tipos de convenentes, sugerindo a existência de variabilidade de valor de repasse para contratos provenientes de instituições diferentes para os contratos de economia solidária. A Tabela 34 evidencia os principais resultados obtidos e os outputs completos estão evidenciados no Apêndice C (Tabela 35).

ii) Modelo de interceptos aleatórios

\begin{tabular}{|c|c|c|}
\hline Indicador de repasse & Coeficiente & \\
\hline documentos_ind & 0,08 & $* *$ \\
\hline ind_subcontratos & 0,16 & $* * *$ \\
\hline ind_TA & 0,11 & $* * *$ \\
\hline ind_prorrogação & 0,31 & $* * *$ \\
\hline ind_parecer_resgate & $-0,45$ & $* * *$ \\
\hline indservicoscomrecursodoconve & $-0,16$ & $* *$ \\
\hline ind_parecer_rejeição & $-0,63$ & $* * *$ \\
\hline \multicolumn{3}{|l|}{ Parâmetros de efeitos aleatórios } \\
\hline $\operatorname{var}\left(\_\right.$cons $)$ & 0,01 & \\
\hline var(Residual) & 0,02 & \\
\hline ICC & 0,33 & \\
\hline LR test vs. modelo linear: chibar2 $(01)=19,37$ & Prob $>=$ chibar $2=0,0000$ & \\
\hline
\end{tabular}

iii) Análise dos resultados do modelo

O modelo de interceptos aleatórios para os contratos vinculados às políticas de economia solidária retornou 7 variáveis significativas em termos estatísticos, todas elas indicadoras (Tabela 34).

As variáveis indicadoras entrega de relatório de documentos (documentos_ind), existência de subcontratos (ind_subcontratos), de termos aditivos (ind_TA) e de prorrogação (ind_prorrogação) apresentaram coeficientes positivos e, portanto, uma relação diretamente proporcional ao indicador de repasse, ceteris paribus.

Vale salientar que para os modelos, considerando a totalidade dos contratos e para o que aborda somente os contratos monitorados pela SPPE, a variável indicadora de termos aditivos (ind_TA) não retornou como significante. Apesar disso, apresentou-se expressiva a variável quantidade de termos aditivos (quantidade_termosaditivos). 
Indicador de parecer de resgate (ind_parecer_resgate), de gastos com serviços com recursos do convênio (indservicoscomrecursodoconve) e de parecer de rejeição (ind_parecer_rejeição) apresentaram coeficiente com sinal negativo e, portanto, possuem relação inversa com o aumento do indicador de repasse, ceteris paribus.

O resultado indica que para os contratos de economia solidária, quanto maior o repasse realizado pelo governo central para os contratos firmados e finalizados, menor a observância de gastos com serviços e de pareceres de rejeição e de resgate.

Os resultados sugerem que para contratos de economia solidária que apresentaram maiores indicadores de repasse, há incidência de subcontratos e de prorrogação de prazo de execução. Resultado similar foi encontrado para o modelo que considera a totalidade dos contratos.

\section{d) Comparação dos resultados dos modelos de indicador de repasse}

As variáveis referentes a subcontratos, a prorrogação de prazo, a termos aditivos e a relatórios de documentos foram comuns e significantes nos três modelos construídos: modelo geral (todos os contratos), modelo com contratos monitorados pela SPPE (políticas de emprego) e modelo com contratos monitorados pela Senaes (políticas de economia solidária).

De uma maneira geral, os resultados indicam que um maior indicador de repasse relaciona-se com a existência de subcontratos, de termos aditivos e deprorrogação de prazo para execução.

A Tabela 36 sintetiza os sinais das relações comuns aos três modelos multivariados analisados e as Tabelas 37, 38 e 39 do Apêndice C corroboram o sinal dessas relações (outputs da matriz de correlação):

Tabela 36: Variáveis comuns aos três modelos e seus sinais

\begin{tabular}{|lccc|}
\hline \multirow{2}{*}{ Variáveis/Modelo } & \multicolumn{3}{c|}{ Relação com Indicador de repasse } \\
& Geral & SPPE & Senaes \\
\hline Subcontratos & + & + & + \\
Termos aditivos & + & + & + \\
Prorrogação de prazo & + & + & + \\
\hline
\end{tabular}

Em relação aos subcontratos, é de se esperar que uma maior disponibilidade de recursos promova os meios de execução, ou seja, que os convenentes firmem subcontratos para que possam alcançar os objetivos e metas estabelecidos nos planos de trabalho. 
Um achado interessante consistena relação positiva e significante do indicador de repasse e a existência de prorrogação de prazo. Nos contratos em que existem os maiores indicadores de repasse, há prorrogação de prazo.

Esse resultado levanta as seguintes suposições (i) o indicador de repasse é alto, porém os desembolsos não são tempestivos; (ii) o indicador de repasse é alto, entretanto, a estrutura institucional não consegue implementar os objetivos e metas firmados no plano de trabalho dentro do prazo de vigência normal do contrato.

Ainda, um maior indicador de repasse vincula-se à existência de termos aditivos. É importante salientar que para amostra de contratos analisada, os principais motivos de termos aditivos são prorrogação de prazo e alterações nos montantes de repasse.

Assim, apesar de a variável significante ser a presença de termos aditivos, sem especificar o motivo do termo aditivo, é de se esperar que exista uma sinergia entre as informações dos termos aditivos e as de prorrogação de prazo. 


\section{HIPÓTESE DA PESQUISA: A existência de determinadas características contratuais e de execução está relacionada a uma probabilidade significativa de o contrato não ser cumprido.}

Nesta seção, serão apresentados os resultados e análises dos modelos logísticos, essenciais para o alcance do objetivo de propor um modelo de priorização de monitoramento de contratos e testar a hipótese de que existem variáveis de execução capazes de antecipar se um contrato será cumprido ou não.

Esta pesquisa tem como premissa que a implementação dos contratos de políticas sociais é influenciada pelas características dos contratos firmados e pelas instituições que os estabelecem em uma relação de agência como governo central. Nesse sentido, a estratégia de utilização de modelos multiníveis vai ao encontro das premissas estabelecidas até então.

A fim de responder aos objetivos da pesquisa e propor um modelo de priorização de monitoramento de transferências voluntárias que possa, a priori, identificar quais contratos que possuem propensão a não serem cumpridos, foi construído um modelo de regressão logística binária multinível.

Para a construção desse modelo, foram considerados somente variáveis cadastrais, de execução e de entrega de relatórios que, apesar de serem insumos para a prestação de contas, estão disponíveis concomitante a execução. Adicionalmente, para o teste dessa hipótese da pesquisa, não foi utilizada nenhuma variável referente às metas contratuais.

As variáveis relacionadas às metas não foram consideradas pois optou-se por desenvolver um modelo que apresentasse variáveis que fossem comuns a todos os convênios de transferências voluntárias, independentemente da política pública estudada. A relação entre o cumprimento do contrato e as variáveis referentes às metas serão testadas posteriormente, em outras seções desta tese.

Importante relembrar que no Apêndice A, que apresenta aspectos legais e normativos de transferências voluntárias, foi mencionado que algumas ações de monitoramento vinculadas à prestação de contas são realizadas no mesmo momento que a execução dos contratos, com vistas a diminuir o risco de não execução.

Dessa forma, os valores de information values, apresentados na seção 4.2 já são um indicativo das variáveis possuem maior poder de segregar cumpridores de não cumpridores, de forma 
bivariada. Os modelos logísticos buscam evidenciar como e quais variáveis segregam cumpridores e não cumpridores, de maneira multivariada.

Dito isso, a seguir são apresentados os resultados dos modelos logísticos construídos.

\section{a) Contratos cumpridos versus contratos não cumpridos: totalidade dos contratos finalizados}

O modelo logístico é construído baseando-se em eventos e não eventos. Nesse sentido, o modelo construído, que contém a totalidade dos contratos finalizados da amostra, considerou como evento o não cumprimento do contrato.

A escolha do não cumprimento como evento justifica-se pela importância de se elencar como e quais características cadastrais, de execução e de prestação de contas (somente aquelas possíveis de serem obtidas durante a execução contratual) são relevantes para compor a chance do evento contrato não cumprido.

A seguir, serão apresentados os resultados dos modelos, dos testes de verificação e a análise dos resultados.

i) Modelo nulo

O modelo nulo foi estimado considerando a escolha institucional como variável de nível 2. Os principais resultados estão evidenciados na Tabela 40 :

Tabela 40: Modelo nulo (contratos finalizados)

\begin{tabular}{|lcccc|}
\hline Nível 2 & ICC & Erro padrão & Intervalo de confiança $(\mathbf{9 5 \%})$ \\
\hline escolha & 0,03 & 0,03 & 0,00 & 0,17 \\
\hline LR test vs. modelo logístico tradicional: chibar2 $(01)=\mathbf{5 , 8 5}$ & Prob $>=$ chibar2 $=\mathbf{0 , 0 0 7 8}$ \\
\hline
\end{tabular}

O modelo nulo indica que aproximadamente $3 \%$ da variância total dos termos de erro é devido à alteração do tipo de convenente.A utilização de modelos hierárquicos é recomendada, conforme indica o p-valor do LR teste (menor que 5\%).

ii) Modelo de interceptos aleatóriose modelo de interceptos e inclinações aleatórias

Na confecção da pesquisa, verificou-se que os modelos hierárquicos não lineares logísticos, de interceptos aleatórios e de interceptos e inclinações aleatórias, não se apresentaram como a 
melhor forma de estimação dos parâmetros, uma vez que o LR test, que compara a aderência dos parâmetros do modelo hierárquico logístico com a aderência dos parâmetros do modelo logístico tradicional, apresentou p-valor muito superior a 5\% (ver os resultados evidenciados no Apêndice C (Tabela 41).

O fato de as escolhas institucionais dos diferentes tipos de convenentes não interferir no intercepto do modelo de cumprimento contratual é um resultado interessante, pois sugere que o cumprimento do contrato depende muito mais das suas características cadastrais e de execução individualdo que dos fatores institucionais e da relação agente-principal.

Dessa maneira, foi construído um modelo logístico binário tradicional, com vistas a cumprir o objetivo específico de sugerir um modelo de priorização de monitoramento de contratos pelas secretarias responsáveis pelas políticas públicas sociais estudadas.

O resultado do modelo logístico tradicional que contempla a totalidade dos contratos analisados é evidenciado na Tabela 42.

Tabela 42: Modelo logístico para priorização de monitoramento (total de contratos finalizados)

\begin{tabular}{|lcc|}
\hline Variáveis & Chance & \\
PT_prazo & 0,26 & $* * *$ \\
ind_rejeição_pagamentos & 0,26 & $* *$ \\
PT_metas & 13,74 & $* * *$ \\
indoutroscomrecursodoconveni & 2,32 & $* * *$ \\
indicadorderepasse & 0,07 & $* * *$ \\
ind_subcontratos & 0,08 & $* * *$ \\
ind_rejeição_fisico & 0,15 & $* *$ \\
\hline Nível de Confiança: $* * *(99 \%) ; * *(95 \%)$ & &
\end{tabular}

iii) Análise dos resultados do modelo

O modelo logístico indicou 7 variáveis significativas para segregar contratos cumpridos de contratos não cumpridos (Tabela 42).

As variáveis indicadoras solicitação de mudança de prazo para execução do plano de trabalho (PT_prazo), rejeição relatórios físicos (ind_rejeição_fisico) e de pagamentos (ind_rejeição_pagamentos) eindicador de subcontratos (ind_subcontratos) apresentaram sinal negativo em relação à ocorrência do evento não cumprir o contrato; assim como a variável métrica indicador de repasse (indicadorderepasse), ceteris paribus. 
Já as variáveis indicadoras de solicitação de mudança de metas para execução do plano de trabalho (PT_metas) e de existência de outros gastos com recursos do convênio (indoutroscomrecursodoconveni) apresentaram sinal positivo em relação ao não cumprimento do contrato, ceteris paribus.

A Tabela 42 evidenciao valor da chance, que cada variável possui, para o não cumprimento do contrato. Conforme explicam Fávero \& Belfiore (2017), a chance de ocorrência do evento é dada da seguinte forma:

$$
\text { Chance }=\frac{p_{i}}{1-p_{i}}(24)
$$

Onde $p_{i}$ é a probabilidade de ocorrência do evento.

Dessa maneira, a Tabela 42 evidencia que se o indicador de repasse é $1 \%$ maior, a probabilidadede o contrato não ser cumprido diminui em 93\%. Os resultados demonstram também que a existência de subcontratos diminui em aproximadamente $92 \%$ a probabilidade de o convênio não ser cumprido, corroborando com a literatura internacional de que a existência de subcontratos faz com que a contratualização seja bem-sucedida.

Outro resultado interessante relaciona-se ao monitoramento tempestivo, por parte das secretarias responsáveis. A rejeição dos relatórios de pagamentos com recursos do convênio e dos relatórios de metas físicas estabelecidas no plano de trabalho, pelo menos uma vez, diminui em $74 \%$ e $85 \%$, respectivamente, a probabilidade de o contrato não ser cumprido.

Esse resultado demonstra que o monitoramento da prestação de contas concomitantemente à execução do convênio, alertando o convenente sobre as deficiências já existentes, é essencial para que os convênios sejam cumpridos eas políticas públicas implementadas.

A solicitação de mudança no prazo de execução do plano de trabalho diminui a probabilidade de o convênio não ser cumprido em, aproximadamente $74 \%$, mantidas constantes as demais variáveis. Esse resultado demonstra a dificuldade que os convênios têm em serem executados nos prazos de vigência inicialmente firmados.

A existência de solicitação de mudanças nas metas previstas nos planos de trabalho e de outros gastos com recursos financeiros são indícios de que os contratos não serão cumpridos. A presença dessas variáveis aumenta a probabilidade de não cumprimento do contrato em $1.274 \%$ 
para a solicitação de mudanças nas metas e $131 \%$ para existência de outros gastos com recursos do convênio.

Em contabilidade, classifica-se em outras categorias de gastos aqueles montantes considerados imateriais. No caso dos convênios, a existência de classificações dessa natureza aumenta a probabilidade de contrato não ser cumprido, suscitando dúvidas em relaçãoà discricionariedade do gestor e sobre os níveis de delegação e de monitoramento necessários.

A partir da obtenção do modelo logístico, é possível realizar uma análise de sensibilidade. A análise da sensibilidade é composta pela análise da sensitividade, da especificidade e da classificação geral do modelo, considerando um ponto de corte (cutoff).

A sensitividade é definida como a probabilidade de o modelo classificar como evento uma observação que, na realidade, é um não evento. Ou seja, é o percentual de acerto, para um determinado ponto de corte, considerando apenas as observações que são eventos. Ao contrário, a especificidade é definida como a probabilidade de o modelo classificar como não evento uma observação que na prática é um evento; isto é, o percentual de acerto, considerando um dado ponto de corte, apenas das observações que não são evento. Assim, a eficiência geral do modelo é o percentual de acerto total do modelo para o ponto de corte estabelecido (Vaz, 2009; Fávero \& Belfiore, 2017). Conforme mencionado anteriormente, o evento é o contrato não cumprido.

O ponto de corte auxilia o pesquisador a avaliar a real incidência do evento para cada observação e assim comparar com a classificação feita pelo modelo, explicam Fávero \& Belfiore (2017). Para esta pesquisa, será considerado um ponto de corte de 0,3 ; ou seja, se a $p_{i}>0,3$, a observação será classificada como evento; caso contrário, será classificada como não evento.

A escolha deste cutoff se justifica (a) pelo fato da amostra apresentar aproximadamente $30 \%$ de eventos (não cumpridores de contrato) e $70 \%$ de não eventos (cumpridores de contrato) e; (b) pela análise da curva de sensibilidade, que permite analisar o valor de ponto de corte que aproxima o valor da sensitividade ao da especificidade (Ilustração 22). 


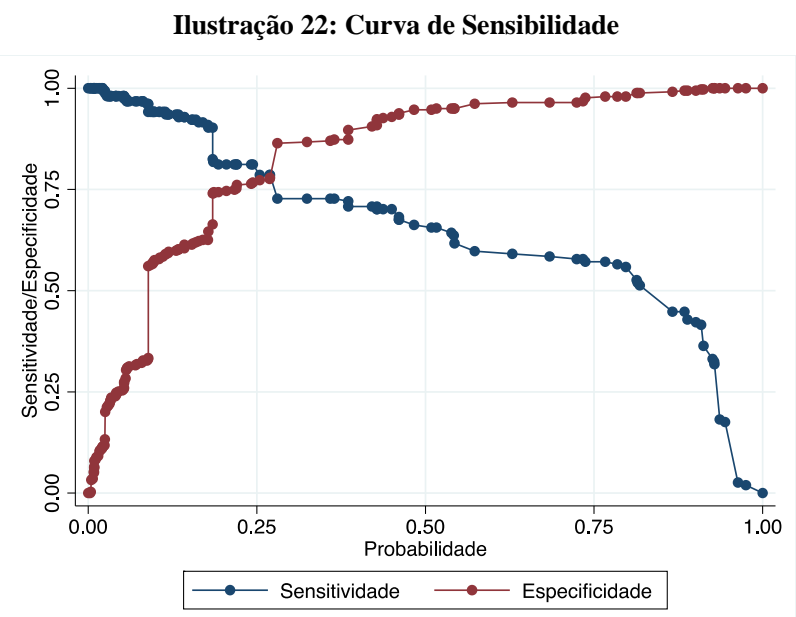

Assim, a Tabela 43 compara as classificações do modelo com a classificação real e evidencia os valores de sensitividade e especificidade considerando um ponto de corte de $30 \%$.

Tabela43: Classificação e Sensibilidade (cutoff $=0,3$ )

\begin{tabular}{|lccc|}
\hline \multicolumn{1}{|c|}{ Modelo/Real } & Evento & Não evento & Total \\
Evento & 112 & 45 & 157 \\
Não evento & 42 & 294 & 336 \\
Total & 154 & 339 & 493 \\
\hline Sensitividade & & $72,73 \%$ & \\
Especificidade & & $86,73 \%$ & \\
Classificação geral do & $82,35 \%$ & \\
modelo & & & \\
\hline
\end{tabular}

O resultado demonstra que este modelo apresenta melhor assertividade na previsão dos não eventos, ou seja, previsão dos contratos cumpridos. No entanto, em termos gerenciais, identificar as variáveis que aumentam e diminuem a chance de não cumprimento dos contratos de políticas públicas sociais parece ser crucial para o processo decisório relacionado ao controle e monitoramento. O modelo apresenta uma alta eficiência geral (aproximadamente 82\%), além de variáveis significantes importantes para compor as probabilidades de ocorrência de evento e não evento.

A área sob a curva ROC (Receiver Operating Characteristic) é uma medida que resume o desempenho de um modelo logístico. Assim, uma área igual a 1 representa um teste perfeito, ou seja, um modelo que acerta todos os eventos e não eventos. Logo, quanto maior a área sob a curva ROC, melhor é a classificação do modelo (Vaz, 2009; Fávero \& Belfiore, 2017).

A Ilustração23 evidencia a curva ROC e sua área. 


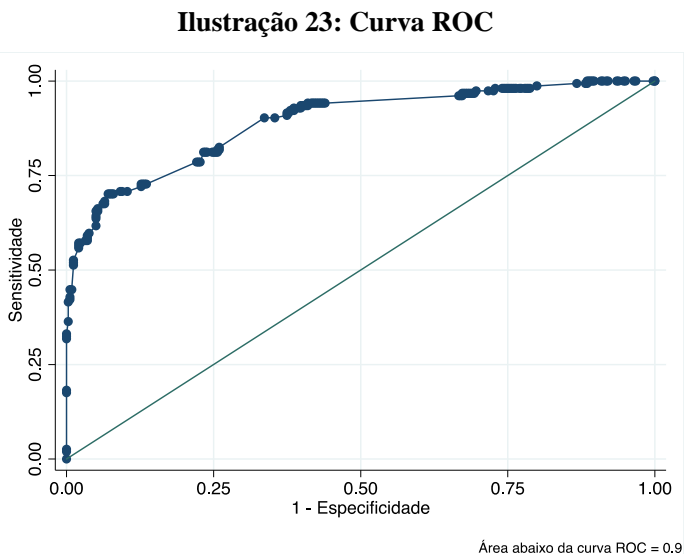

Destaca-se que a área abaixo da curva ROC do modelo que contempla a totalidade dos contratos finalizados da amostra é de 0.9; demonstrando que o modelo apresenta um bom desempenho para segregar cumpridores e não cumpridores de contrato, para a amostra estudada.

\section{b) Contratos cumpridos integralmente versus contratos cumpridos parcialmente}

Para fins gerenciais, foi feito um corte amostral para construção de um modelo que segregasse contratos cumpridos integralmente dos contratos cumpridos parcialmente. O intuito, ao construir este modelo, foi verificar quais fatores são decisivos para que o convenente cumpra todos os objetivos (integralmente) firmadosno convênio com o MTE.

i) Modelo nulo

O modelo nulo foi estimado considerando a escolha institucional como variável de nível 2. Os principais resultados estão evidenciados na Tabela 44:

Tabela 44: Modelo Nulo

\begin{tabular}{|ccccc|}
\hline Nível 2 & ICC & Erro padrão & Intervalo de confiança (95\%) \\
\hline escolha & 0,07 & 0,07 & 0,07 & 0,38 \\
\hline LR test vs. modelo logístico tradicional: chibar2 $(01)=\mathbf{8 , 4 0}$ & Prob >= chibar2 = 0,0019 \\
\hline
\end{tabular}

Os resultados do modelo nulo indicam que aproximadamente $7 \%$ da variância total dos termos de erro é devido à alteração do tipo de convenente. A utilização de modelos hierárquicos é recomendada, conforme indica o p-valor menor que 5\% do LR teste.

ii) Modelo de interceptos aleatórios e modelo de interceptos e inclinações aleatórias 
De maneira similar ao modelo logístico para cumpridores e não cumpridores, para o modelo que segrega os contratos cumpridos integralmentedos contratos cumpridos parcialmente,a estimaçãohierárquicanão se apresentou como a mais adequada para obtenção dos parâmetros, uma vez que o LR test, que compara a aderência dos parâmetros do modelo hierárquico logístico com a aderência dos parâmetros do modelo logístico tradicional, apresentou p-valor muito superior a 5\% (ver os resultados obtidos no Apêndice C, Tabelas 45 e 46).

Assim, foi construído modelo logístico por meio da especificação tradicional. Os resultados e análise são apresentados na Tabela 47.

Tabela 47: Modelo gerencial (integralmente versus parcialmente)
\begin{tabular}{|lcc|}
\hline Variáveis & Chance & \\
PT_prazo & 2,82 & $* * *$ \\
indicadorderepasse & 68,99 & $* * *$ \\
\hline
\end{tabular}
Nível de Confiança: $* * *(99 \%) ; *(95 \%)$

iii) Análise do modelo logístico

Os resultados da Tabela 47 evidenciam que as variáveis solicitação de mudança de prazo para execução do plano de trabalho (PT_prazo) e indicador de repasse (indicadorderepasse) são as únicas variáveis significantes para discriminar os contratos cumpridos parcialmente dos cumpridos parcialmente e ambas variáveis apresentaram sinal positivo, ceteris paribus.

Assim, a chance de que um contrato seja cumprido integralmente é 1,82 vez maior em contratos em que há solicitação de mudança de prazo (probabilidade de $182 \%$ maior) quando comparados com contratos os quais não há essa solicitação. Ainda, um aumento de $1 \%$ no indicador de repasse aumenta em 67,99 vezes a chance de contrato ser cumprido integralmente.

Portanto, os resultados sugerem que solicitação de mudança de prazo e maior repasse de recursos são determinantes para a obtenção de contratos cumpridos integralmente.

Apesar de o resultado ser interessante, o modelo não apresentou estatísticas de sensibilidade satisfatórias. A Ilustração 24 evidencia o valor de ponto de corte que aproxima o valor da sensitividade ao da especificidade, valor em torno de 0,7 . 
Ilustração 24: Curva de Sensibilidade

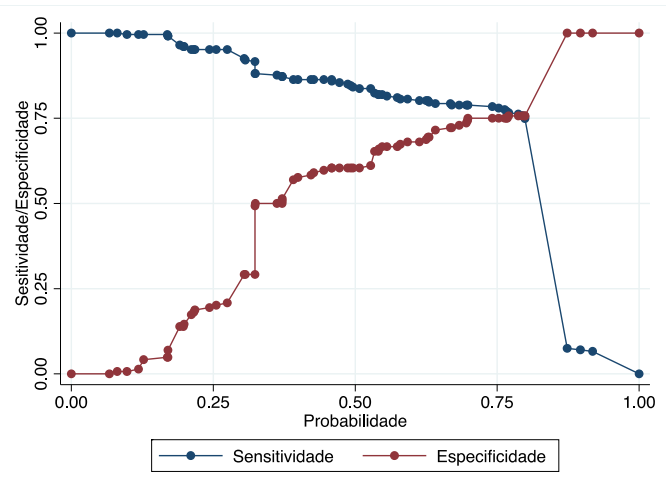

Assim, a Tabela 48 compara as classificações feitas pelo modelo e a classificação real dos contratos cumpridos, bem como os valores de sensitividade e especificidade considerando um ponto de corte de 70\%. A Ilustração 25 evidencia a curva ROC e sua área.

\begin{tabular}{|c|c|c|c|}
\hline \multicolumn{4}{|c|}{ Tabela 48: Classificação e Sensibilidade (cutoff $=0,7$ ) } \\
\hline Modelo/Real & Evento & Não evento & Total \\
\hline Evento & 178 & 36 & 214 \\
\hline Não evento & 49 & 108 & 157 \\
\hline Total & 227 & 144 & 371 \\
\hline Sensitividade & & $78,41 \%$ & \\
\hline Especificidade & & $75,00 \%$ & \\
\hline $\begin{array}{l}\text { Classificação geral do } \\
\text { modelo }\end{array}$ & & $77,09 \%$ & \\
\hline
\end{tabular}

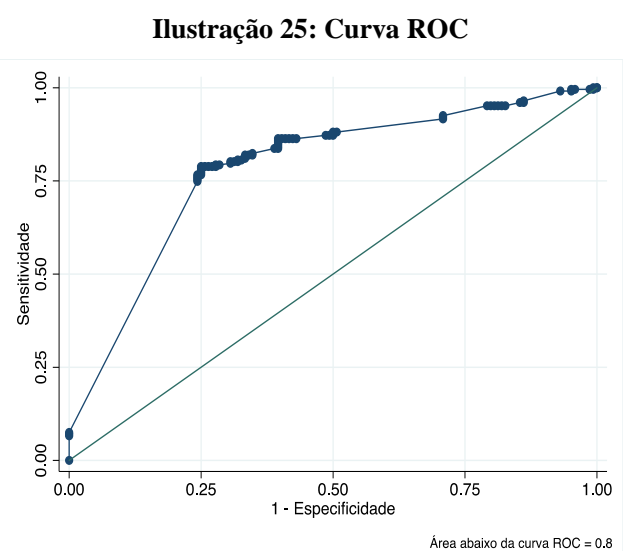

O modelo apresenta uma alta eficiência geral (aproximadamente 77\%). Destaca-se que a área abaixo da curva ROC é de 0,8 , valor baixo para os padrões utilizados em modelos de risco de default.

\section{c) Modelo por política pública: contratos cumpridos versus contratos não cumpridos}

Nesta seção, serão apresentados, conjuntamente, os modelos logísticos para os contratos referentes às políticas públicas de emprego e de economia solidária. Os procedimentos 
utilizados para a construção do modelo para os contratos de emprego serão os mesmos realizados para o modelo logístico que considerou a totalidade dos contratos finalizados.

Desta forma, serão considerados como evento o contrato não cumprido, de forma a obter as variáveis significantes e que contribuem, positiva ou negativamente, para ocorrência deste evento.

O objetivo, ao desenvolver modelos por política, é verificar se as variáveis que são determinantes para obtenção de contratos não cumpridos (eventos) são semelhantes para cada umas das políticas sociais estudadas na pesquisa.

\section{i) Modelo Nulo}

AsTabelas 49 e 50 evidenciam os resultados para o modelo nulo, a primeira especificação construída ao se adotar procedimentos hierárquicos.

Tabela 49: Modelo nulo (políticas de emprego)

\begin{tabular}{|ccccc|}
\hline Nível 2 & ICC & Erro padrão & Intervalo de confiança (95\%) \\
\hline escolha & 0,02 & 0,02 & 0,00 & 0,18 \\
\hline LR test vs. modelo logístico tradicional: chibar2 $(01)=\mathbf{2 , 8 9}$ & Prob >= chibar2 = 0,0445 \\
\hline
\end{tabular}

Tabela 50: Modelo nulo (políticas de economia solidária)

\begin{tabular}{|lccc|}
\hline \multicolumn{4}{|c}{ Tabela 50: Modelo nulo (políticas de economia solidária) } \\
\hline Nível 2 & ICC & Erro padrão & Intervalo de confiança (95\%) \\
\hline escolha & 0,00 & 0,04 & - \\
\hline LR test vs. modelo logístico tradicional: chibar2 $(01)=\mathbf{2 , 9 e - 0 3}$ & Prob >= chibar2 = 0,4787 \\
\hline
\end{tabular}

O resultado do modelo nulo evidenciou que, para as políticas de emprego, a chance de não cumprir o contrato é diferente entre os diferentes tipos de convenente. Assim, aproximadamente $2 \%$ da variância total dos termos de erro é devido à alteração do tipo de convenente. A utilização de modelos hierárquicos é recomendada, conforme indica o p-valor do LR teste, menor que 5\%.

Entretanto, o resultado do modelo nulo para as políticas de economia solidária revelou que não há alteração total dos termos de erros referentes a alterações nos tipos de convenente e o LR test apresentou p-valor muito superior a 5\%, revelando que os modelos logísticos tradicionais apresentam melhores parâmetros de estimação. 
ii) Modelo de interceptos aleatórios e modelo de interceptos e inclinações aleatórias

Os modelos hierárquicos não lineares logísticos para contratos de políticas de emprego, de interceptos aleatórios e de interceptos e inclinações aleatórias não se apresentaram como a melhor forma de estimação dos parâmetros, o LR test, que compara a aderência dos parâmetros do modelo hierárquico logístico com a aderência dos parâmetros do modelo logístico tradicional, apresentou p-valor muito superior a 5\% (ver os resultados obtidos no Apêndice C, Tabelas 51 e 52).

Assim, os modelos para os contratos de cada uma das políticas foram desenvolvidos por estimação tradicional. A Tabela 53 evidencia os resultados do modelo logístico por política e o geral (que considera a totalidade de contratos,já analisados na seção anterior). Os outputs completos dos resultados estão evidenciados nas Tabelas 54 a 57 do Apêndice C):

\begin{tabular}{|c|c|c|c|c|c|c|}
\hline \multirow[b]{3}{*}{ PT_prazo } & \multicolumn{6}{|c|}{ Chance } \\
\hline & \multicolumn{2}{|c|}{ Geral } & \multicolumn{2}{|c|}{ SPPE } & \multicolumn{2}{|c|}{ Senaes } \\
\hline & 0,26 & $* * *$ & 0,21 & $* * *$ & & \\
\hline ind_rejeição_pagamentos & 0,26 & ** & & & & \\
\hline PT_metas & 13,74 & $* * *$ & 16,59 & **** & & \\
\hline indoutroscomrecursodoconveni & 2,32 & $* * *$ & 2,18 & $* *$ & & \\
\hline indicadorderepasse & 0,07 & $* * *$ & 0,08 & $* * *$ & 0,02 & $* * *$ \\
\hline ind_subcontratos & 0,08 & $* * *$ & 0,07 & $* * *$ & 0,03 & $* * *$ \\
\hline ind_rejeição_fisico & 0,15 & $* *$ & & & & \\
\hline ind_rejeição_documentos & & & 0,06 & $* *$ & & \\
\hline ind_rejeição_receitadespesa & & & & & 0,14 & *** \\
\hline
\end{tabular}

iii) Análise do modelo logístico binário tradicional

O modelo por política pública também retornou as variáveis indicadoras de existência de pelo menos um subcontrato (ind_subcontratos) e indicador de repasse (indicadorderepasse) como significantes e com relação negativa para discriminar contratos cumpridos de contratos não cumpridos.

Assim, os resultados evidenciaram que para cada $1 \%$ a mais de repasse de recursos do governo central, a probabilidade de não cumprir o contrato (evento) diminui em mais de $90 \%$ para as 
políticas estudadas, mantidas as demais condições constantes (92\% para as políticas de emprego e $98 \%$ para as políticas de economia solidária), ceteris paribus.

Adicionalmente, o fato de existir pelo menos um subcontrato firmado também diminui a probabilidade de não cumprimento do contrato em 93\% para as políticas de emprego e 97\% para as de economia solidária.

Além dessas duas variáveis mencionadas, quatro outras variáveis são significantes para segregar cumpridores e não cumpridores de contratos em políticas de emprego. Duas variáveis se relacionam positivamente com o evento (não cumprimento): a solicitação de mudança das metas previstas no plano de trabalho (PT_metas) e o indicador de outros tipos de gastos com recursos do convênio (indoutroscomrecursodoconveni), ceteris paribus.

Os resultados indicam que quando há, no contrato vinculado à política de emprego, solicitação de mudanças das metas estabelecidas no plano de trabalho, a probabilidade de o contrato não ser cumprido aumenta 15,59 vezes. De maneira semelhante, quando há aplicação de recursos do convênio em tipos de despesas classificados como outros, isto é, classificação do gasto mais genérica, a probabilidade de o contrato não ser cumprido aumenta em $118 \%$.

Ainda referente às políticas de emprego, as variáveis indicadoras de que os relatórios de documentos foram rejeitados pelo menos uma vez pelo concedente (ind_rejeição_documentos) e de solicitação de mudanças no prazo de execução do plano de trabalho (PT_prazo) possuem relação negativa com o não cumprimento dos contratos monitorados pela SPPE. Assim, a existência de pelo menos uma rejeição do relatório de documentos diminui a probabilidade de o contrato não ser cumprido em 94\%; já a solicitação de mudanças no prazo de execução do plano de trabalho diminui em $79 \%$ a probabilidade de um contrato de emprego não ser cumprido.

Em relação à economia solidária, a variável indicadora de pelo menos uma rejeição do relatório de receitas e despesas (ind_rejeição_receitadespesa) por parte da concedente diminui a probabilidade de o contrato não ser cumprido em $86 \%$.

Os resultados sugerem que o monitoramento tempestivo durante a execução é uma forma de evitar o não cumprimento do contrato e ter maiores possibilidades de uma implementação mais efetiva das políticas estudadas em nível local. 
A fim de verificar a sensibilidade do modelo e sua assertividade, foram desenvolvidas as curvas e estatísticas de sensibilidade e o gráfico da curva ROC. Para as políticas de emprego, o modelo apresenta área abaixo da curva ROC de 0.89 enquanto que para as políticas de economia solidária, o modelo apresenta área de 0.88 , demonstrando que os modelos separados apresentam uma boa estimação (Ilustrações 26 e 27 - Apêndice C).

As estatísticas de sensibilidade dos modelos construídos para os contratos de política de emprego e de economia solidária são demonstradas na Tabela 58, junto com os pontos de corte que equilibram a sensitividade e a especificidade de cada política. As curvas de sensibilidade e a ROC estão demonstradas no Apêndice C.

Tabela 58: Análise de sensibilidade

\begin{tabular}{|c|c|c|c|}
\hline \multicolumn{4}{|l|}{ SPPE $($ cutoff $=0.3$ ) } \\
\hline Modelo/Real & Evento & $\begin{array}{c}\text { Não } \\
\text { evento }\end{array}$ & Total \\
\hline Evento & 98 & 40 & 138 \\
\hline Não evento & 29 & 167 & 196 \\
\hline Total & 127 & 207 & 334 \\
\hline Sensitividade & & $77,17 \%$ & \\
\hline Especificidade & & $80,68 \%$ & \\
\hline Classificação geral do modelo & & $79,34 \%$ & \\
\hline \multicolumn{4}{|l|}{ Senaes $($ cutoff $=0.2)$} \\
\hline Modelo/Real & Evento & $\begin{array}{c}\text { Não } \\
\text { evento }\end{array}$ & Total \\
\hline Evento & 18 & 8 & 26 \\
\hline Não evento & 7 & 83 & 90 \\
\hline Total & 25 & 11 & 116 \\
\hline Sensitividade & & $72,00 \%$ & \\
\hline Especificidade & & $91,21 \%$ & \\
\hline Classificação geral do modelo & & $87,07 \%$ & \\
\hline
\end{tabular}

Em relação à Tabela 58, é importante ressaltar o alto índice de acerto da classificação obtido para os contratos referentes à economia solidária, sobretudo sobre o poder que o modelo tem para classificar corretamente os não eventos (no caso da pesquisa, os contratos cumpridos).

\section{d) Síntese dos resultados dos modelos logísticos}

Para alcançar o objetivo de propor um modelo de priorização de monitoramento dos convênios de políticas públicas sociais de emprego e renda foram desenvolvidos modelos logísticos que contivessem variáveis capazes de segregar contratos não cumpridos (eventos) e cumpridos (não eventos). 
Dessa maneira, foram construídos três modelos: (i) a totalidade dos contratos finalizados; (ii) os contratos finalizados das políticas de emprego, monitoradas pela SPPE; e (iii) os contratos finalizados das políticas de economia solidária, monitoradas pela Senaes (comparativo demonstrado na Tabela 53). Foi construído, adicionalmente, (iv) um modelo que elencou as variáveis que segregam os contratos cumpridos parcialmente do que cumpridos integralmente para fins gerenciais.

Como o objetivo foi construir um modelo de priorização de controle e monitoramento com base no mapeamento das variáveis que segregam contratos cumpridos de contratos não cumpridos, verificou-se que as variáveis indicador de repasse e indicador de subcontratos são altamente relevantes para discriminar eventos e não eventos nos três modelos construídos (geral, emprego e economia solidária - Tabela 53).

Um repasse $1 \%$ maior de recursos pelo governo central diminui em mais de $90 \%$ a probabilidade de o contrato não ser cumprido, ceteris paribus. Esse resultado corrobora com a literatura pois demonstra, por meio de análise microanalítica, a dependência dos entes e das organizações da sociedade civil em relação aos recursos federais para a implantação de políticas públicas em nível local. $\mathrm{O}$ achado ainda contribui com a literatura porque evidencia a magnitude dessa dependência (ver Ilustrações 1 e 2, capítulo 2).

A existência de pelo menos um subcontrato na execução do convênio também diminui a chance de o contrato não ser cumprido em mais de $90 \%$, nos resultados dos três modelos construídos (geral, emprego e economia solidária - Tabela 53). Esse achado está em linha com a literatura de contratualização de políticas públicas sociais evidenciada no capítulo 2 (Ilustração 1), que indica que quanto maior o número de subcontratos firmados pelos agentes contratados, maior a chance de a contratualização ser bem-sucedida.

A partir dos achados foi possível verificar que a forma de gestão, controle e monitoramento para as duas políticas não parecem ser idênticas, sugerindo a necessidade de se construir um modelo de priorização de gestão, controle e monitoramento para cada política (há outras variáveis que segregam contratos cumpridos e não cumpridos que não são comum aos dois modelos).

Assim, os achados da pesquisa podem auxiliar os gestores a priorizarem o acompanhamento dos contratos que apresentaram determinadas características (significantes em cada modelo), 
de forma a garantir que os objetivos e metas estabelecidos nos planos de trabalho sejam cumpridos, em algum grau e as políticas públicas previstas implementadas. 


\section{HIPÓTESE DA PESQUISA: As metas inicialmente estabelecidas para um mesmo serviço divergem entre os diferentes tipos de instituições convenentes.}

Nesta seção, serão apresentados os resultados dos modelos construídos para as metas quantitativas e suas respectivas análises.

Conforme mencionado em seções anteriores, entende-se que a implementação dos contratos de políticas sociais é influenciada pelas características estabelecidas nos contratos e pelas características das instituições que os estabeleceram, em uma relação de agência com o governo central.

Dessa maneira, a fim de responder aos objetivos da pesquisa e verificar se as metas estabelecidas nos planos de trabalho são diferentes entre os tipos de convenentes, foi construído um modelo de regressão multinível para dados em contagem, que busca verificar se existem diferenças no estabelecimento de metas quantitativas entre as entidades privadas, os estados e distrito federal e os municípios. A utilização de modelos para dados em contagem se explica porque as variáveis de metas utilizadas são métricas e apresentam apenas valores discretos e não negativos.

Salienta-se que nos modelos confirmatórios anteriores não foram consideradas as variáveis referentes às metas (HLM e logístico). A justificativa para desconsiderar estas variáveis nestes modelos foi o fato dese optar porutilizar neles somente variáveis comuns a outros contratos de transferências voluntárias firmados pelo governo central, independente da política pública estudada.

Todavia, por entender a importância de serelacionar dados de entrada e saída (entre eles, as metas) para promoção do monitoramento dos contratos firmados pelo setor público, nesta seção são apresentados os resultados dos modelos cujas variáveis dependentes são as metas quantitativas previstas inicialmente nos contratos.

Destaca-se que como cada política pública possui especificidades no que concerne à indicadores e metas, os modelos para cada política foram construídos e analisados separadamente.

\section{a) Metas contratuais doscontratos de políticas de emprego}

Os planos de trabalho das políticas de emprego apresentam, quase sempre, as seguintes metas quantitativas: 
1. Quantidade prevista de trabalhadores atendidos para serviços em geral.

2. Quantidade prevista de seguros desempregos habilitados;

3. Quantidade prevista de trabalhadores intermediados;

4. Quantidade prevista de trabalhados qualificados

É importante salientar que existem contratos firmados exclusivamente para qualificação profissional de trabalhadores; para estes contratos, a única meta quantitativa estabelecida é a meta contida em 4.

Portanto, foram construídos modelos cujas variáveis dependentes foram cada uma das metas elencadas ( 1 a 4) relacionando-as com as variáveis grau de cumprimento do contrato, tipo de convenente e indicador de repasse. Os resultados são apresentados nas seções seguintes.

i) Modelos hierárquicos não lineares para dos em contagem

$\mathrm{Na}$ confecção da pesquisa, verificou-se que os modelos hierárquicos para dados em contagem, nulo, de interceptos aleatórios e de interceptos e inclinações aleatórias não apresentaram convergência para a função de verossimilhança e, portanto, não puderam ser utilizados.

Dessa forma, nas próximas seções são apresentados os resultados dos modelos para dados de contagem tradicionais.

ii) Modelos para dados em contagem

Para cumprir o objetivo de verificar a relação entre as metas estabelecidas nos planos de trabalho, o grau de cumprimento do contrato, o indicador de repasse e o tipo de convenente, foi construído um modelo para cada meta elencada.

Os modelos para dados em contagem inflacionados de zerose apresentaram como os mais adequados para os contratos contidos na amostra (ver resultado do Teste de Vuong na nas Tabelas 60 a 63do Apêndice C). A Tabela 59 evidencia os resultados obtidos para as quatro metas quantitativas previstas nos contratos monitorados pela SPPE: 
Tabela 59: Modelo para dados em contagem (metas previstas nos planos de trabalho)

\begin{tabular}{|c|c|c|c|c|c|c|c|c|c|c|c|c|}
\hline \multirow{2}{*}{$\begin{array}{ll} & \text { Meta } \\
\text { Variável }\end{array}$} & \multicolumn{3}{|c|}{ Serviços gerais } & \multicolumn{3}{|c|}{$\begin{array}{c}\text { Seguro- } \\
\text { desemprego }\end{array}$} & \multicolumn{3}{|c|}{ Intermediação } & \multicolumn{3}{|c|}{ Qualificação } \\
\hline & $\beta$ & $\overline{e^{\beta}}$ & & $\beta$ & $e^{\beta}$ & & $\beta$ & $e^{\beta}$ & & $\beta$ & $e^{\beta}$ & \\
\hline indicador & 6,73 & 834,74 & $* * *$ & 2,12 & 8,31 & $* * *$ & 3,46 & 31,86 & $* * *$ & $-5,55$ & 0,00 & $* * *$ \\
\hline _Igrau_não & 2,18 & 8,83 & $* * *$ & 1,76 & 5,83 & $* * *$ & 1,56 & 4,76 & $* * *$ & $-1,85$ & 0,16 & $* * *$ \\
\hline _Igrau_parcialmente & 0,82 & 2,27 & $* * *$ & 0,28 & 1,33 & $* * *$ & 0,96 & 2,60 & $* * *$ & 1,76 & 5,81 & $* * *$ \\
\hline _Iescolha_município & $-1,12$ & 0,33 & $* * *$ & $-2,30$ & 0,10 & $* * *$ & $-1,71$ & 0,18 & $* * *$ & 1,56 & 4,78 & $* * *$ \\
\hline _Iescolha_estado & & & & & & & & & & $-0,78$ & 0,46 & $* * *$ \\
\hline \multicolumn{13}{|l|}{ inflação } \\
\hline _Igrau_não & & & & 2,11 & 8,22 & $* * *$ & 1,76 & 5,80 & $* * *$ & & & \\
\hline _Iescolha_município & $-1,34$ & 0,26 & $* *$ & $-3,29$ & 0,04 & $* * *$ & $-3,02$ & 0,05 & $* * *$ & 1,16 & 3,20 & $*$ \\
\hline Teste Vuong (não corrigido) & \multicolumn{3}{|c|}{$26,17 * * *$} & \multicolumn{3}{|c|}{$30,14^{* * * *}$} & \multicolumn{3}{|c|}{$20,53 * * *$} & \multicolumn{3}{|c|}{$3,31 * *$} \\
\hline Teste de Vuong (AIC) & \multicolumn{3}{|c|}{$26,16^{* * *}$} & \multicolumn{3}{|c|}{$30,13^{* * *}$} & \multicolumn{3}{|c|}{$20,63 * * *$} & \multicolumn{3}{|c|}{$3,30 * *$} \\
\hline Teste de Vuong (BIC) & \multicolumn{3}{|c|}{$26,16^{* * *}$} & \multicolumn{3}{|c|}{$30,13 * * *$} & \multicolumn{3}{|c|}{$20,63 * * *$} & \multicolumn{3}{|c|}{$3,30 * *$} \\
\hline
\end{tabular}

Nível de Confiança: *** $(99 \%) ; * *(95 \%) ; *(90 \%)$

iii) Análise dos resultados dos modelos

Os resultados dos modelos desenvolvidos serão apresentados por meta prevista no plano de trabalho, conforme evidenciados na Tabela 59.

\section{META 1: quantidade prevista de trabalhadores atendidos para serviços em geral}

O resultado do teste de Vuong evidencia a melhor adaptação do modelo inflacionado de zeros em relação ao modelo Poisson, dado que o $p$-valor obtido é menor 5\% (Tabela 59).

Portanto, os contratos firmados com os municípios são negativa e estatisticamente significantes para explicar a quantidade excessiva de zeros nas metas previstas de serviços gerais. Assim, os resultados demonstram que os contratos firmados com os municípios possuem probabilidade 74\% menor de estabelecerem metas de serviços gerais iguais a zero, quando comparados com os contratos firmados com entidades privadas sem fins lucrativos (categoria de referência), ceteris paribus.

Ainda os resultados evidenciam que a taxa média de serviços gerais oferecidos é 834 vezes maior para os contratos que apresentaram $1 \%$ a mais de indicador de repasse e que os contratos cumpridos parcialmente instituíram metas de serviços gerais aproximadamente 1,3 vezes maior do que os contratos cumpridos integralmente, mantidas constantes as demais variáveis.

Em relação à variável indicadora de não cumprimento de contrato, verificou-se que os contratos não cumpridos possuem metas previstas 7,8 vezes maiores de oferta de serviços gerais do que os contratos cumpridos integralmente para amostra analisada, ceteris paribus. 


\section{META 2: quantidade prevista de seguros desempregos habilitados}

O resultado do teste de Vuong evidencia o melhor ajustamento do modelo inflacionado de zeros em relação ao modelo Poisson, uma vez que o $p$-valor obtido é menor 5\%.

Portanto, as variáveis indicadoras de não cumprimento de contrato e de contrato firmado com município são significantes para explicar a quantidade excessiva de zeros nas metas previstas para habilitação de seguro desemprego, ceteris paribus. (Tabela 59)

Os contratos firmados com os municípios possuem $96 \%$ menos probabilidade de estabelecer metas de habilitação de seguro desemprego iguais a zero do que as entidades privadas sem fins lucrativos.

A análise da taxa de incidência revela que a meta média de seguros habilitados é 7,3 vezes maior para os contratos que apresentaram $1 \%$ a mais de indicador de repasse. Os contratos cumpridos parcialmente apresentaram metas de seguro desemprego aproximadamente $33 \%$ maiores do que os contratos cumpridos integralmente, mantidas constantes as demais variáveis.

\section{META 3: quantidade prevista de trabalhadores intermediados}

O resultado do teste de Vuong evidencia a adequação do modelo para dados em contagem inflacionado de zeros, uma vez que o $p$-valor obtido é menor $5 \%$.

Os contratos firmados com municípios apresentam uma relação negativa e significante com a quantidade de metas estabelecidas para intermediação de mão de obra. Os resultados indicam que a chance de um contrato firmado com o municípionão propor metas de intermediação de mão de obra é, aproximadamente, $95 \%$ menor do que a chance deum contrato firmado com entidades privadas sem fins lucrativos. Destaca-se que as duas variáveis são significativas para explicar a quantidade de zeros estruturais (ver Tabela 59).

Em relação à taxa média de incidência, a variável indicadora de cumprimento parcial dos contratos evidencia que, mantidas as demais condições constantes, os contratos cumpridos parcialmente estabeleceram meta aproximadamente 1,60 vezesmaior do que os contratos cumpridos integralmente.

Ainda, mantidas as demais condições constantes, a taxa média de metas de intermediação propostas é 30,9 vezes maior para os contratos que apresentaram $1 \%$ a mais de indicador de repasse, isto é, $3.086 \%$ a mais. 


\section{META 4: quantidade prevista de trabalhados qualificados}

Os resultados não revelaram variáveis estatisticamente significantes a 95\% de confiança para inflação de zeros, apesar de o teste de Vuong sugerir uma melhor adequação do modelo inflacionado de zero em relação ao modelo Poisson, dado que o $p$-valor obtido é menor 5\% (ver Tabela 59).

Assim, as metas propostas de trabalhadores qualificados apresentaram resultados diferentes dos obtidos para as outras metas. E essa diferença é justificada pelo fato de alguns contratos relacionadas às políticas de emprego estabelecerem apenas metas de qualificação.

A Tabela 59 demonstra que a taxa média prevista de trabalhadores qualificados é $99 \%$ menor para os contratos que apresentaram $1 \%$ a mais de indicador de repasse. Os contratos cumpridos parcialmente apresentaram metas de qualificação 4,8 vezes menores do que os contratos cumpridos integralmente, ceteris paribus. Esses achados são contrários aos verificados, para as mesmas variáveis, nas metas anteriores.

Adicionalmente, os resultados de metas para qualificação profissional revelaram a variável indicadora do tipo de convenente estado como significativa no modelo de metas de qualificação de trabalhadores. Assim, os estados estabelecem metas médias de qualificação de trabalhadores $54 \%$ menores que as entidades privadas sem fins lucrativos, diferentemente dos municípios que, ao estabelecerem metas de qualificação para os contratos analisados, estabelecem metas 3,8 vezes maiores que as entidades privadas (aproximadamente $378 \%$ maiores, conforme Tabela 59).

iv) Síntese dos resultados obtidos para as metas dos contratos das políticas de emprego

A Tabela64 evidencia o sinal da relação multivariada entre as variáveis significantes nos modelos. A Tabela 65 (Apêndice C) evidencia os sinais da relação bivariada. Destaca-se que só estão contidos na tabela as variáveis comuns a todos os modelos multivariados cujos sinais foram idênticos nas Tabelas 64 e 65. 


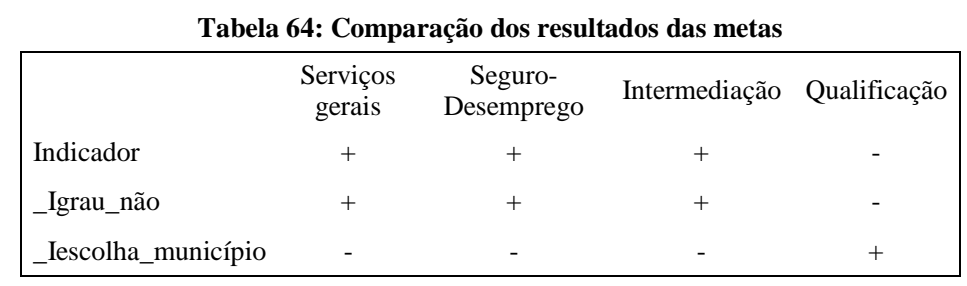

Em resumo, os resultados revelam que há uma relação positiva entre o indicador de repasse e a quantidade de metas previstas, o que indica que, aparentemente, metas maiores (de serviços gerais, seguro e intermediação) estão relacionadas a indicadores de repasse também maiores.

Em relação ao grau de cumprimento do contrato, verificou-se também uma relação positiva entre as metas e a variável indicadora de contrato não cumprido, indicando que os contratos não cumpridos estabeleceram metas médias maiores do que os contratos cumpridos integralmente.

Por fim, o interessante resultado obtido para a variável indicadora contratos firmados com municípios. Os resultados sugerem que os contratos com municípios estabeleceram metas diferentes de zero e provavelmente maiores que as propostas pelas entidades privadas sem fins lucrativos para três das metas contratuais previstas (serviços gerais, intermediação e habilitação de seguro).

Assim, considerando que os entes federados são os mais penalizados com contingência de recursos público federais (resultados evidenciados nas seções anteriores), o fato de os municípios estabelecerem metas muito superiores às organizações não governamentais compromete ainda mais sua capacidade de execução de contratos, além de indicar uma capacidade inferior de estabelecer um planejamento condizente com a possibilidade de execução.

Destaca-se que os resultados para as metas de qualificação profissional não foram similares aos obtidos para as outras metas (serviços gerais, intermediação e habilitação de seguro).

\section{b) Metas contratuais: contratos de políticas de economia solidária monitorados pela Senaes}

Os planos de trabalho das políticas de economia solidária apresentam, quase sempre, as seguintes metas quantitativas:

1. Quantidade prevista de bancos comunitários (BC) assessorados;

2. Quantidade prevista de bancos comunitários estruturados; 
3. Quantidade prevista de empreendimentos econômicos solidários (EES) assessorados;

4. Quantidade prevista de empreendimentos econômicos solidários estruturados;

Dessa maneira, os contratos de políticas de economia solidária analisados podem apresentar pelo menos uma ou todas as metas nos seus planos de trabalho. De maneira similar ao realizado para as políticas de empregoforam construídos, primeiramente, modelos hierárquicos e casos esses não apresentassem a melhor estimação, seriam construídos modelos tradicionais.

Para a construção dos modelos para dados de contagem cujas variáveis são as metas quantitativas da política de economia solidária, também foram utilizadas as variáveis referentes aos tipos de convenente, ao grau de cumprimento do contrato e ao indicador do repasse.

i) Modelos hierárquicos não lineares para dados em contagem

Para as metas de economia solidária, foram construídos modelos hierárquicos para dados em contagem e modelos para dados em contagem com inflação de zeros.

Os resultados dos modelos hierárquicos de interceptos aleatórios e de interceptos e inclinações aleatórias demonstraram que existe variabilidade significativa entre os tipos de convenentes no que concerne à previsão de metas contratuais em economia solidária, pois o valor do LR test apresentou p-valor inferior a 5\% (Tabelas 66 a 73 - Apêndice C).

ii) Modelos hierárquicos não lineares para dados em contagem

Apesar dos resultados dos modelos hierárquicos demonstrarem melhor estimação quando comparado com os modelos Poisson tradicionais, os testes de especificação demonstraram que os modelos para dados em contagem com inflação de zeros possuem melhores estimadores que os hierárquicos. A Tabela 74evidencia os resultados do Likelihood-ratio test, que compara os estimadores.

Tabela 74: Resultados do likelihood-ratio test

\begin{tabular}{|c|c|c|c|c|}
\hline & $\begin{array}{c}\text { Assessoria a } \\
\text { bancos } \\
\text { comunitários }\end{array}$ & $\begin{array}{c}\text { Criação de } \\
\text { bancos } \\
\text { comunitários }\end{array}$ & $\begin{array}{c}\text { Assessoria de } \\
\text { EES }\end{array}$ & $\begin{array}{c}\text { Estruturação } \\
\text { de EES }\end{array}$ \\
\hline Contagem hierárquico (LL) & $-1022,49$ & $-538,69$ & $-21114,79$ & $-2905,39$ \\
\hline Contagem inflacionado de zeros (LL) & $-392,65$ & $-218,53$ & $-15510,53$ & $-1825,59$ \\
\hline
\end{tabular}


O modelo com inflação de zeros possui os menores valores de função de verossimilhança e esses valores são estatisticamente significantes a 99\% de confiança. Por essa razão, na Tabela 75 são apresentados os resultados dos modelos para dados em contagem com inflação de zeros.

Tabela75: Modelo de dados em contagem para as metas previstas nos planos de trabalho

\begin{tabular}{|c|c|c|c|c|c|c|c|c|c|c|c|c|}
\hline \multirow[b]{2}{*}{ Variável } & \multicolumn{3}{|c|}{$\begin{array}{c}\text { Assessoria a } \\
\text { bancos } \\
\text { comunitários }\end{array}$} & \multicolumn{3}{|c|}{$\begin{array}{l}\text { Criação de bancos } \\
\text { comunitários }\end{array}$} & \multicolumn{3}{|c|}{ Assessoria de EES } & \multicolumn{3}{|c|}{$\begin{array}{c}\text { Estruturação de } \\
\text { EES }\end{array}$} \\
\hline & $\beta$ & $e^{\beta}$ & & $\beta$ & $e^{\beta}$ & & $\beta$ & $e^{\beta}$ & & $\beta$ & $e^{\beta}$ & \\
\hline indicador & 0,45 & 1,57 & $*$ & $-3,65$ & 0,03 & $* * *$ & $-1,86$ & 0,16 & $* * *$ & 2,50 & 12,17 & $* * *$ \\
\hline _Igrau_não & 0,20 & 1,23 & & $-0,24$ & 0,79 & & $-0,90$ & 0,41 & $* * *$ & $-0,01$ & 0,99 & \\
\hline _Igrau_parcialmente & $-0,36$ & 0,70 & $* * *$ & 0,20 & 1,22 & & $-1,27$ & 0,28 & $* * *$ & $-0,56$ & 0,57 & $* * *$ \\
\hline _Iescolha_estado & $-2,62$ & 0,07 & $* * *$ & $-2,65$ & 0,07 & $* * *$ & $-1,40$ & 0,25 & $* * *$ & 0,37 & 1,45 & $* * *$ \\
\hline _Iescolha_município & $-2,99$ & 0,05 & $* * *$ & $-4,11$ & 0,02 & $* * *$ & $-0,40$ & 0,67 & $* * *$ & 0,98 & 2,66 & $* * *$ \\
\hline \multicolumn{13}{|l|}{ inflação } \\
\hline indicador & 0,51 & 1,67 & & $-3,18$ & 0,04 & & $-0,27$ & 0,76 & & 1,33 & 3,79 & \\
\hline _Igrau_não & $-0,09$ & 0,91 & & $-0,85$ & 0,43 & & $-0,54$ & 0,58 & & 0,37 & 1,44 & \\
\hline _Igrau_parcialmente & $-1,08$ & 0,34 & & $-0,44$ & 0,65 & & $-0,46$ & 0,63 & & 0,66 & 1,93 & \\
\hline _Iescolha_estado & 0,20 & 1,22 & & $-0,51$ & 0,60 & & $-0,94$ & 0,39 & & $-0,10$ & 0,90 & \\
\hline _Iescolha_município & 0,39 & 1,47 & & $-2,18$ & 0,11 & & $-0,09$ & 0,91 & & $-0,04$ & 0,96 & \\
\hline Teste Vuong (não corrigido) & \multicolumn{3}{|c|}{$4,10 * * *$} & \multicolumn{3}{|c|}{$3,48 * *$} & \multicolumn{3}{|c|}{$2,17 * *$} & \multicolumn{3}{|c|}{$3,54 * *$} \\
\hline Teste de Vuong (AIC) & \multicolumn{3}{|c|}{$4,06^{* * *}$} & \multicolumn{3}{|c|}{$3,42 * *$} & \multicolumn{3}{|c|}{$2,16^{* *}$} & \multicolumn{3}{|c|}{$3,51 * *$} \\
\hline Teste de Vuong (BIC) & \multicolumn{3}{|c|}{$4,00 * * *$} & \multicolumn{3}{|c|}{$3,32 * *$} & \multicolumn{3}{|c|}{$2,15 * *$} & \multicolumn{3}{|c|}{$3,47 * *$} \\
\hline
\end{tabular}

Nível de Confiança: *** (99\%);**(95\%); *(90\%)

iii) Análise dos resultados dos modelos

Os resultadosdos modelos por meta são descritos na próxima seção, a partir da análise da Tabela 75. É importante salientar que os outputs completos de cada um dos modelos inflacionados de zero estão evidenciados nas Tabelas 76 a 79 do Apêndice C.

\section{META 1: quantidade prevista de bancos comunitários assessorados}

Apesar de as variáveis indicador, grau de cumprimento e escolha institucional não serem significativas a 95\% de confiança para a inflação de zeros, o resultado do teste de Vuong evidencia a adequação do modelo para dados em contagem inflacionados de zeros, uma vez que o p-valor obtido é menor $1 \%$ (Tabela 75$)$. 
Em relação à quantidade de bancos comunitários assessorados previstos nos contratos da amostra, os resultados indicam que um valor de indicador de repasse $1 \%$ maior relaciona-se a uma quantidade média prevista de assessoriasa bancos comunitários $57 \%$ maior.

Mantidas constantes todas as condições, os resultados revelam que os contratos cumpridos parcialmente continham metas médias de assessoria a bancos comunitários aproximadamente $30 \%$ menores, quando comparados com os contratos cumpridos integralmente.

Em relação aos tipos de convenente, os entes federados apresentaram relação inversa e significante com as metas previstas para assessoria de bancos comunitários.

Assim, estados e municípios preveem metas médias menores $93 \%$ e 95\%, respectivamente, de assessoria a bancos comunitários que as entidades privadas sem fins lucrativas.

\section{META 2: quantidade prevista de bancos comunitários estruturados}

Em relação à previsão de metas de criação de bancos comunitários, os resultados obtidos foram similares aos obtidos para as metas de assessoria para os tipos de convenentes. Portanto, os resultados revelam que estados e municípios estimam metas relacionadas à criação de bancos comunitários $93 \%$ e $99 \%$ menores que as entidades privadas sem fins lucrativos, ceteris paribus (Tabela 75).

Diferentemente do encontrado para a meta de assessoria a bancos comunitários, para a meta de criação de bancos foi encontrada uma relação negativa e significante com o indicador de repasse. Assim, os resultados indicam que para os contratos analisados, o aumento em 1\% no indicador de repasse relaciona-se a metas quantitativas médias $97 \%$ menores, ceteris paribus.

\section{META 3: quantidade prevista de empreendimentos econômicos solidários assessorados}

Em relação à previsão de assessorias a empreendimentos econômicos solidários (EES), os resultados obtidos indicam que os estados e municípios estabelecem metas $75 \%$ e 33\%, respectivamente, menores que as entidades privadas sem fins lucrativos.

Adicionalmente, os contratos não cumpridos e os parcialmente cumpridos apresentaram metas $59 \%$ e $72 \%$ menores que os contratos cumpridos integralmente para a meta de assessoria de EES.

O indicador de repasse é negativamente relacionado com a quantidade média de EES assessorados. Portanto, um valor $1 \%$ maior de indicador de repasse relaciona-se com metas 
$84 \%$ menores de assessoria à EES. Os resultados obtidos são mantidos se mantidas todas as demais condições constantes.

\section{META 4: quantidade prevista de empreendimentos econômicos solidários estruturados}

As metas previstas para a criação de EES apresentaram como variáveis significativas o indicador de repasse, o cumprimento parcial do contrato e os convenentes estado e município.

Os resultados sugerem que, ao contrário do que acontece para as metas anteriores, no que concerne à estruturação de EES, os estados e municípios estabelecem metas $45 \%$ e 166\% maiores que as entidades privadas sem fins lucrativos. Adicionalmente, os resultados indicam que os contratos parcialmente cumpridos apresentaram metas $43 \%$ menores que os contratos cumpridos parcialmente, ceteris paribus.

Em relação ao indicador de repasse, um valor de indicador de repasse $1 \%$ maior vincula-se à meta de estruturação de EES 11 vezes maior, mantidas constantes as demais condições.

iv) Síntese dos resultados obtidos para as metas dos contratos das políticas de economia solidária

A Tabela 80 relaciona as principais variáveis e seus respectivos sinais multivariados com as metas quantitativas dos contratos de economia solidária. A Tabela 81 do Apêndice C evidencia o sinal das relações bivariadas:

Tabela 80: Comparação dos resultados das metas

\begin{tabular}{|lcccc|}
\hline & $\begin{array}{c}\text { Assessoria a } \\
\text { bancos } \\
\text { comunitários }\end{array}$ & $\begin{array}{c}\text { Estruturação } \\
\text { de bancos } \\
\text { comunitários }\end{array}$ & $\begin{array}{c}\text { Assessoria de } \\
\text { EES }\end{array}$ & $\begin{array}{c}\text { Estruturação de } \\
\text { EES }\end{array}$ \\
Indicador & + & - & - & + \\
Iescolha_estado & - & - & - & + \\
_Iescolha_município & - & - & - & + \\
\hline
\end{tabular}

O comportamento do indicador de repasse foi diferente entre as diferentes metas instituídas, apesar de relevante para explicar as quantidades médias estabelecidas.

As relações obtidas indicam que os entes federados, estados, distrito federal e municípios apresentam metas quantitativas médias menores que as entidades privadas sem fins lucrativos no que se refereà maioria das metas quantitativas analisadas, exceto para a meta de estruturação de EES. 
Os achados corroboram com a literatura de economia solidária (sobretudo com a Avaliação Externa) que dispõe que, de uma maneira geral, são as organizações da sociedade civil as maiores responsáveis por conservarem/manterem as políticas de economia solidária efetivas no Brasil, sobretudo após 2014.

Todavia, o fato de estados e municípios apresentarem metas maiores que entidades privadas para a estruturação de EES é um resultado interessante, pois demonstra que quando há necessidade de ações modificadoras da realidade econômica, sobretudo no que diz respeito à forma de obtenção de renda da população de uma determinada região, são os entes federados os responsáveis pela mudança, uma vez que estruturar EES envolve executar tanto despesas relacionadas a custeio (correntes), mas sobretudo às despesas referentes aos investimentos (de capital).

E relacionado a isso, pode-se destacar o papel das universidades estatuais (exemplo de convênio estadual) que, conforme demonstra a literatura, têm papel fundamental na estruturação de empreendimentos econômicos solidários no país 


\section{RESUMODOSPRINCIPAISACHADOS EMPÍRICOS}

Ao realizar análise empírica dos convênios de políticas públicas de emprego e de economia solidária da amostra, os seguintes resultados foram verificados para a amostra analisada:

1. Há diferenças estatisticamente significantes no que concerne ao repasse de recursos públicos federais previamente estabelecidos, e isso influenciou o indicador de repasse dos contratos finalizados e, consequentemente, os resultados obtidos na implementação dos contratos firmados, baseado no que sugeriram os trabalhos clássicos de Williamson (1998) e Horn (1995).

a. As organizações da sociedade civil (entidades privadas sem fins lucrativos) são mais privilegiadas no repasse de recursos públicos federais, e esse resultado foi verificado tanto para os contratos de políticas de emprego quanto para os contratos de políticas de economia solidária. Esse resultado amplia o encontrado por Smith \& Lispky (1993); Suárez (2011); Lecy \& Slyke (2012) e Boyer \& Kolpakov (2017).

b. Quando há necessidade de se contingenciar recursos, os contratos com os entes federados (estados, distrito federal e municípios) são mais penalizados que os contratos com as organizações da sociedade civil, indicando que há diferenças na relação entre os diferentes convenentes (agentes) e o governo central (principal). Esse resultado foi, em partes, similar ao verificado por Pires Júnior (2003) e Moutinho (2016).

c. Há uma relação positiva e significante entre o indicador de repasse e a existência de prorrogação de prazo contratual. Assim, nos contratos em que há maior relação entre o valor repassado pelo governo central (liberado) e o valor previamente conveniado, há incidência de termos aditivos para prorrogação do prazo de execução.

2. Existem características que, quando identificadas na execução contratual, auxiliam os gestores, sobretudo os gestores do governo central, no processo decisório relacionado à gestão e à priorização do controle e do monitoramento dos convênios firmados.

a. A decisão por contingenciar recursos previamente conveniados influencia significativamente na capacidade do convenente em executar os convênios 
firmados, e o montante dessa influência é alto: a cada $1 \%$ a menos de valor liberado pelo governo central em relação ao valor previamente conveniado aumenta a probabilidade de não cumprimento das metas e objetivos em mais de $90 \%$, mantidas as demais condições constantes. Esse resultado relacionase com o encontrado por Smith \& Lispky (1993); Slyke (2003); Heinrich \& Choi (2007);

b. A existência de subcontratos é um indicador de que a implementação do contrato está sendo realizada, e ao realizar pelo menos um subcontrato, o convênio aumenta sua probabilidade de cumprir metas e objetivos em mais de $90 \%$.

c. A identificação das características contratuais mais relevantes para gestão e processo decisório deve ser feita para cada tipo de política, separadamente. Existem características que auxiliam na gestão e na tomada de decisão referentes aos contratos de uma política, mas que não são relevantes para gestão e processo decisório de outra (s), mesmo que os contratos das duas políticas possuam as mesmas características. Esse resultado relaciona-se, em parte, com o encontrado por Fine et al. (2016).

3. As organizações convenentes estabelecem, em seus planos de trabalho, metas quantitativas distintas para a execuçãodos mesmos serviços.

\section{a. Em relação às políticas de emprego:}

i. As organizações da sociedade civil (entidades privadas sem fins lucrativos) estabelecem metas quantitativas menores do que os entes federados (estados, distrito federal e municípios) em seus planos de trabalho.

ii. Os contratos não cumpridos e os cumpridos parcialmente estabeleceram metas médias maiores do que os contratos cumpridos integralmente para maioria das metas contratuais no período estudado.

iii. Os contratos firmados pelos municípios possuem metas médias quantitativas superiores às estabelecidas pelas entidades privadas sem fins lucrativos. 
b. Em relação às políticas de economia solidária:

i. Os entes federados (estados, distrito federal e municípios) estipularam metas menores que as organizações da sociedade civil para maioria das metas quantitativas analisadas.

ii. Não foi verificada uma relação estatisticamente significante entre o estabelecimento de metas e o grau de cumprimento dos contratos de economia solidária.

Portanto, foi abordado cada um dos objetivos estabelecidos e testada todas as hipóteses estabelecidas na pesquisa (Ilustração 10). A Ilustração 28 relaciona os objetivos, as hipóteses e os principais achados da análise empírica realizada na pesquisa: 
Ilustração 28: Relação entre objetivo, hipóteses e principais achados

\begin{tabular}{|c|c|c|c|}
\hline Objetivo & Hipótese & Situação & Achados da Pesquisa \\
\hline $\begin{array}{l}\text { Verificar como a relação de agência entre as } \\
\text { instituições convenentes e o governo central } \\
\text { influencia a gestão e monitoramento dos } \\
\text { arranjos contratuais firmados entre eles. } \\
\text { Relacionar a teoria da agência e a teoria dos } \\
\text { custos de transação aplicados ao setor público, } \\
\text { em uma perspectiva complementar. }\end{array}$ & $\begin{array}{l}\text { Há diferenças no estabelecimento de metas e } \\
\text { objetivos, na execução e nos resultados } \\
\text { obtidos pelos contratos firmados em virtude } \\
\text { da relação entre agente e principal. }\end{array}$ & Aceita & $\begin{array}{l}\text { Há diferenças no repasse de recursos públicos federais previamente estabelecidos, o que } \\
\text { impacta o indicador de repasse dos contratos e, consequentemente, influencia os } \\
\text { resultados dos contratos finalizados. }\end{array}$ \\
\hline $\begin{array}{l}\text { Verificar os efeitos do indicador de repasse na } \\
\text { execução e prestação de contas dos contratos } \\
\text { firmados, em uma perspectiva da relação de } \\
\text { agência. }\end{array}$ & $\begin{array}{l}\text { As diferenças médias no indicador de repasse } \\
\text { dos contratos são explicadas pela relação de } \\
\text { agência das instituições convenentes com o } \\
\text { governo central. As alterações no indicador de } \\
\text { repasse promovem alterações na forma como } \\
\text { o contrato é executado e na sua prestação de } \\
\text { contas. }\end{array}$ & Aceita & $\begin{array}{l}\text { 1) Em contratos nos quais há uma maior relação entre o valor repassado pelo governo } \\
\text { central (liberado) e o valor previamente conveniado, há incidência de termos aditivos } \\
\text { para prorrogação do prazo de execução. 2) A decisão por contingenciar recursos } \\
\text { previamente conveniados influencia significativamente na capacidade do convenente em } \\
\text { executar os convênios firmados, aumentando a probabilidade de o contrato não ser } \\
\text { cumprido em mais de } 90 \% \text {. }\end{array}$ \\
\hline $\begin{array}{l}\text { Propor um modelo de priorização de } \\
\text { monitoramento de contratos baseado nas } \\
\text { características dos contratos e na sua } \\
\text { execução. }\end{array}$ & $\begin{array}{l}\text { A existência de determinadas características } \\
\text { contratuais e de execução estão relacionadas a } \\
\text { uma probabilidade significativa de o contrato } \\
\text { não ser cumprido. }\end{array}$ & Aceita & $\begin{array}{l}\text { 1) Existem características que, quando identificadas na execução contratual, auxiliam os } \\
\text { gestores, sobretudo os federais, no processo decisório relacionado à gestão e à } \\
\text { priorização do controle e do monitoramento dos convênios firmados. 2) A identificação } \\
\text { das características contratuais mais relevantes para gestão e processo decisório deve ser } \\
\text { feita para cada tipo de política, separadamente. }\end{array}$ \\
\hline $\begin{array}{l}\text { Verificar como a relação de agência influencia } \\
\text { o estabelecimento das metas previstas nos } \\
\text { contratos. }\end{array}$ & $\begin{array}{l}\text { As metas inicialmente estabelecidas para um } \\
\text { mesmo serviço divergem entre os diferentes } \\
\text { tipos de instituições convenentes. }\end{array}$ & Aceita & $\begin{array}{l}\text { As organizações convenentes estabelecem, em seus planos de trabalho, metas } \\
\text { quantitativas distintas para a execução dos mesmos serviços. }\end{array}$ \\
\hline
\end{tabular}





\section{CONSIDERAÇÕES FINAIS}

O objetivo da pesquisa foi verificar como a relação de agência entre as instituições convenentes e o governo central influencia a gestão e o monitoramento dos contratos de transferências voluntárias (convênios) de políticas de emprego e economia solidária.

Para testar as hipóteses da pesquisa, foram utilizados os fundamentos das teorias da agência (TA) e dos custos de transação (TCE) de forma complementar, substanciando a análise empírica na governança das relações contratuais (Williamson, 1988; Horn, 1995).

Portanto, de forma similar aos estudos empíricos sobre contratos de serviços públicos sociais, para confecção da pesquisa, examinou-se a governança das relações contratuais considerando a discricionariedade gerencial e a eficiência dos contratos (Van Slyke, 2002; Van Slyke, 2003; Fine et al., 2016; Lecy \& Thornton, 2016).

Os achados da pesquisa corroboram com a tese de que a relação prévia entre as instituições e o governo central (em uma relação agente-principal) auxilia a explicar:

I. O repasse efetivo do governo central;

II. A forma de gestão, de controle e de monitoramento dos contratos firmados; e

III. A aprovação dos planos de trabalho submetidos à análise do governo central.

A pesquisa demonstrou que o repasse efetivo é realizado de forma diferente entre as instituições convenentes. O governo central priorizou o repasse de recursos às entidades privadas sem fins lucrativos para a maioria das cohorts de contratos analisadas. $\mathrm{O}$ fato de as entidades privadas sem fins lucrativos terem apresentado indicadores de repasse maiores, em média, que os estados, o Distrito Federal e os municípios para as duas políticas analisadas, parece contribuir para que a frequência de contratos cumpridos por elas fosse maior.

Em relação à aprovação de planos de trabalho, os achados revelaram que há diferenças institucionais no estabelecimento das metas quantitativas que preveem a execução de serviços similares, mas que essa diferença não possui efeitos idênticos nas duas políticas examinadas.

Para os contratos de economia solidária, verificou-se que estados, o Distrito Federal e os municípios estabelecem metas quantitativas menores que as entidades privadas, mas não é possível afirmar que há uma relação entre as metas estabelecidas e o cumprimento dos contratos. 
Para os contratos de políticas de emprego, verificou-se que estados, o Distrito Federal e os municípios estabelecem metas quantitativas maiores que as entidades privadas e que sim, há uma relação entre o estabelecimento de metas e o cumprimento do contrato.

Os achados propiciam as seguintes deduções: (i) as entidades privadas possuem melhor capacidade de planejamento e execução, quando comparadas com os entes federados; ou (ii) as entidades privadas possuem melhores relações institucionais com o governo central, o que ajuda a garantir os repasses efetivos e a aprovação de metas quantitativas diferentes dos entes federados para os mesmos serviços.

Para as duas questões levantadas, há respaldos na literatura. Trabalhos recentes verificaram que há melhoria nos indicadores de efetividade com a contratação das entidades privadas sem fins lucrativos para execução de serviços sociais no Brasil e no exterior (Araújo, 2005; Boyer \& Kolpakov, 2017).

Entretanto, a maior parte da literatura de contratualização defende que a explicação se encontra na carência de instituições interessadas em executar contratos de políticas públicas sociais somada à dependência das entidades privadas em relação aos recursos do setor público, fazendo com que tais entidades desenvolvam estratégias gerenciais para garantir a contratação com o governo central e influenciar a implementação de políticas em nível local (Van Slyke, 2003; Suárez, 2011; Fine et al., 2016; Lecy \& Thornton, 2016).

Os resultados obtidos na pesquisa corroboram com a literatura. A pesquisa realizou ainda as seguintes contribuições teóricas:

A primeira refere-se à relação entre agente-principal. A política molda a relação de agência no setor público. No entanto, a influência política no processo de formalização das transferências voluntárias parece ir além da mera liberação de emendas parlamentares em busca de coalizão entre políticos dos diversos entes federados.

Para as políticas de emprego e economia solidária, a influência política parece influenciar a escolha das instituições que receberão o maior repasse efetivo de recursos disponíveis. Nesse aspecto, cabe citar a influência política das entidades privadas sem fins lucrativos que, independentemente da cohort e momento econômico, receberam maiores indicadores de repasses. Destaca-se que as decisões relacionadas ao montante de repasses efetivos possuem um grande impacto no cumprimento dos contratos firmados, conforme demonstrado na análise da pesquisa. 
A segunda contribuição está relacionada às avaliações de políticas públicas em nível organizacional, que necessitam anteceder as avaliações macroeconômicas de programas públicos: primeiro, porque uma política pública pode envolver um ou mais programas; e, segundo, porque as características de execução dos instrumentos de implementação das políticas públicas influenciam nos seus resultados e, consequentemente, podem afetar os indicadores de efetividade vinculadas aos programas (exemplo: o não cumprimento de um convênio que prevê ações relacionadas ao emprego formal pode influenciar na taxa de desemprego da região).

A terceira contribuição é de ordem prático-empírica. Na pesquisa, foi possível propor, em nível gerencial, ferramentas de gestão, controle e monitoramento que levam em conta as características dos contratos ainda no processo de execução.

Por fim, verificou-se que um repasse efetivo maior por parte do governo central ao agente convenente não garante que as metas estabelecidas serão cumpridas. Para as políticas de emprego e economia solidária, o repasse de recursos necessita ser acompanhado de termos aditivos de prorrogação de prazo de execução além do repasse financeiro, o que ressalta (i) a dependência financeira dos convenentes e/ou (ii) a sua pouca capacidade operacional de implementar o plano de trabalho submetido ao governo central no tempo pré-estabelecido.

Apesar das contribuições teóricas e práticas existentes, a pesquisa possui limitações. É importante salientar, primeiramente, que o cálculo do indicador de repasse não levou em consideração os recursos devolvidos pelo convenente à secretaria concedente. Destaca-se que nem todo o recurso liberado pelo governo central ao convenente é, na sua totalidade, utilizado na contratualização.

Segundo, a leitura individual dos contratos e a coleta das variáveis foram feitas por uma só pessoa. Se, por um lado, isso pode sugerir certa subjetividade na interpretação das características contratuais, por outro, denota consistência na interpretação dos dados, já que assim adota-se critérios homogêneos para coleta e análise dos dados.

Ressalta-se, em terceiro lugar, que não foram relacionadas características contratuais e indicadores de efetividade (tais como população, população economicamente ativa, IDH, taxa de desemprego etc.). Essa limitação tem como justificativa as características dos próprios contratos. 
Por meio da leitura particular dos contratos, foi possível verificar que havia convênios que previam ações em mais de um estado, o que fazia com que a utilização de indicadores de efetividade (que geralmente são calculados por estado, município etc.) não fosse possível.

Por fim, não foram analisadas a estabilidade dos parâmetros do modelo de priorização proposto. Ao construir um modelo logístico com fins preditivos, faz-se necessário a utilização de amostras de desenvolvimento e amostras de validação, out-of-time14 (OOT) e out-of-sample15 (OOS). Em virtude do tamanho da amostra de contratos finalizados, não foi possível segregar as amostras para análise de estabilidade dos parâmetros. Caso haja interesse dos gestores em utilizar o modelo na prática, será necessário ampliar a amostra, obter novos parâmetros e realizar a análise da sua estabilidade.

Apesar das limitações elencadas, acredita-se que as contribuições teóricas e empíricas dos achados e o modelo de controle e monitoramento proposto na pesquisa podem auxiliar os gestores do governo central e os convenentes a aperfeiçoarem a gestão das transferências voluntárias; os órgãos de controle externo no processo de análise das prestações de contas; além de promover o controle social e a accountability das ações do poder público.

Para futuras pesquisas, pretende-se analisar as características do convênio em uma perspectiva temporal, considerando a relação entre os fluxos de liberação de recursos federais e sua influência nas características de execução dos convênios.

Sugere-se, também, analisar, em profundidade, a interpretação do convenente sobre a real influência das características de execução nas atividades operacionais. Para isso, pretende-se analisar o conteúdo dos relatórios de prestação de contas, principalmente o relacionado à seção em que os convenentes destacam os principais desafios encontrados no processo de execução do convênio.

Para fins de planejamento e elaboração de futuros planos de trabalho, seria interessante analisar o custo de oportunidade dos contratos não cumpridos em termos de metas não atingidas, uma vez que quando um contrato não cumpre os objetivos e as metas previamente estabelecidos

\footnotetext{
${ }^{14} \mathrm{~A}$ validação de parâmetros em amostras out-of-time (OOT) refere-se à análise da estabilidade dos parâmetros do modelo construído em amostras que possuem contratos pertencentes a outras cohorts e que não estavam presentes na amostra de desenvolvimento.

15 A validação dos parâmetros em amostras out-of-sample (OOS) refere-se à análise da estabilidade dos parâmetros do modelo construído em amostras que possuem outros contratos pertencentes às mesmas cohorts, mas que não estavam presentes na amostra de desenvolvimento.
} 
depreende-se que os desafios públicos continuam existindo, em tese. A análise dessas informações pode retroalimentar ações de planejamento e aperfeiçoar a gestão das transferências voluntárias. 



\section{REFERÊNCIAS ${ }^{16}$}

Acordão TCU n. 1.687. (2009). Monitoramento, Determinações, Arquivamento. Brasília, DF: Tribunal de Contas da União. Recuperado de www.tcu.gov.br/Consultas/Juris/Docs/judoc/Acord/../AC_2838_44_15_P.doc

Alchian, A. A., \& Demsetz, H. (1972). Production, information costs, and economic organization. The American economic review, 62(5), 777-795.

Alexander, J., Nank, R., \& Stivers, C. (1999). Implications of welfare reform: Do nonprofit survival strategies threaten civil society? Nonprofit and Voluntary Sector Quarterly, 28(4), $452-475$.

Amirkhanyan, A. A. (2008). Collaborative performance measurement: Examining and explaining the prevalence of collaboration in state and local government contracts. Journal of Public Administration Research and Theory, 19(3), 523-554.

Amorim Neto, O.,\& Simonassi, A. G. (2013). Bases políticas das transferências intergovernamentais no Brasil (1985-2004). Revista de Economia Política, 33(4), 704-725.

Aranson, P. H., Gellhorn, E., \& Robinson, G. O. (1982). Theory of legislative Delegation. Cornell L. Rev., 68, 1.

Araújo, H. E. (org). (2005). Avaliação de Políticas Públicas de Economia Solidária - Relatório Final. In Ministério do Trabalho e Emprego.

Recuperado de https://pt.scribd.com/document/177255103/Avaliacao-de-Politicas-Publicasde-Economia-Solidaria

Arretche, M., \& Rodden, J. (2004). Política distributiva na federação: estratégias eleitorais, barganhas legislativas e coalizões de governo. Instituto Universitário de Pesquisas do Rio de Janeiro.

Ashley, S. R., \& Van Slyke, D. M. (2012). The influence of administrative cost ratios on state government grant allocations to nonprofits. Public Administration Review, 72(s1).

Baber, W. R. (1983). Toward understanding the role of auditing in the public sector. Journal of Accounting and Economics, 5, 213-227.

Baber, W. R., \& Sen, P. K. (1984). The role of generally accepted reporting methods in the public sector: An empirical test. Journal of Accounting and Public Policy, 3(2), 91-106.

Baião, A. L. (2013). O papel das transferências intergovernamentais na equalização fiscal dos municípios brasileiros. (Dissertação de Mestrado). Escola Brasileira de Administração Pública e de Empresas, Fundação Getúlio Vargas, Rio de Janeiro. 
Baião, A. L., da Cunha, A. S. M., \& de Souza, F. S. R. N. (2017). Papel das transferências intergovernamentais na equalização fiscal dos municípios brasileiros. Revista do Serviço Público, 68(3), 583.

Bãlutã, A. V. (2012). The Role of Accounting and Accounting Law in Establishing Public Economic Policies in the Post-crisis Period. Theoretical and Applied Economics, XIX(6), 111120.

Barnard, C. I. (1938). The functions of the executive.

Beinecke, R. H., \& DeFillippi, R. (1999). The value of the relationship model of contracting in social services reprocurements and transitions: Lessons from Massachusetts. Public Productivity \& Management Review, 490-501.

Bernstein, S. R. (1991). Managing Contracted Services in the Nonprofit Agency: Administrative. Ethical, and Political Issues.

Bijos, D. (2013). Federalismo, instituições políticas e relações intergovernamentais: um estudo sobre os elementos determinantes das transferências voluntárias da União para os municípios do estado de Minas Gerais. (Dissertação de Mestrado). Departamento de Ciência Política, Universidade de Brasília, Brasília.

Bobbio, N. (1992). et alii. Dicionário de política. Brasília: Editora UNB, verbetes Estado Moderno, Estado Contemporâneo, Política e Política Econômica.

Boston, J. (1996). The use of contracting in the public sector-Recent New Zealand experience. Australian Journal of Public Administration, 55(3), 105-110.

Boyer, E., \& Kolpakov, A. (2017). An Empirical Examination of Partnership Frequency and Design within International Nongovernmental Organizations (INGOs). International Journal of Public Administration, 1-12

BRASIL. Lei de Responsabilidade Fiscal. Lei Complementar, 101 de 2001.

Brignall, S., \& Modell, S. (2000). An institutional perspective on performance measurement and management in the 'new public sector'. Management accounting research, 11(3), 281-306.

Brown, T. L., \& Potoski, M. (2004). Managing the public service market. Public Administration Review, 64(6), 656-668.

Brown, T. L., Potoski, M., \& Van Slyke, D. M. (2006). Managing public service contracts: Aligning values, institutions, and markets. Public Administration Review, 66(3), 323-331.

Brown, T. L., Potoski, M., \& Van Slyke, D. M. (2007). Trust and contract completeness in the public sector. Local Government Studies, 33(4), 607-623.

Carruthers, B. G. (1995). Accounting, ambiguity, and the new institutionalism. Accounting, Organizations and Society, 20(4), 313-328. 
Cataia, M. (2011). Federalismo brasileiro. As relações intergovernamentais analisadas a partir das transferências voluntárias (união/municípios). Revista Geográfica de América Central, 2, $1-16$.

Chambre, S. M. (1999). Redundancy, Third-Party Government, and Consumer Choice: HIV/AIDS Nonprofit Organizations in New York City. Policy Studies Journal, 27(4), 840-854.

Cheng, R. H. (1992). An empirical analysis of theories on factors influencing state government accounting disclosure. Journal of Accounting and Public Policy, 11(1), 1-42.

Coase, R. H. (1937). The nature of the firm. economica, 4(16), 386-405.

Coase, R. H. (1972). Durability and monopoly. The Journal of Law and Economics, 15(1), 143149.

Commons, J. R. (1925). Law and economics. The Yale law journal, 34(4), 371-382.

Commons, J. R. (1937). Capacity to produce, capacity to consume, capacity to pay debts. The American Economic Review, 680-697.

Conselho Nacional da Economia Solidária. (2015). Plano Nacional de Economia Solidária (Pnaes). Recuperado de http://www.unisolbrasil.org.br/2015/wpcontent/uploads/2015/06/plano_nacional_de_ecosol_12062015_com_capa.pdf

Constituição da República Federativa do Brasil. (1988, 05 de outubro). Recuperado de http://www.planalto.gov.br/ccivil_03/constituicao/constituicao.htm

Conti, J. M., \& Carvalho, A. C. (2011). O controle interno na Administração Pública brasileira: qualidade do gasto público e responsabilidade fiscal. Direito Público, 8(37).

Cuganesan, S., Briers, M., \& Chua, W. F. (1999). Controls in strategic supplier relationships. UNSW Press.

Cuganesan, S. (2006). The role of functional specialists in shaping controls within supply networks. Accounting, Auditing \& Accountability Journal, 19(4), 465-492.

Cuganesan, S. (2007). Accounting, contracts and trust in supply relationships. Journal of Accounting \& Organizational Change, 3(2), 104-125.

Dallaverde, A. K. (2015). As transferências voluntárias no modelo constitucional brasileiro(Tese de Doutorado, Faculdade de Direito, Universidade de São Paulo). Recuperado de www.teses.usp.br

D’Abadia, B. M. (2015). A problemática das transferências voluntárias. InConsultoria Legislativa da Câmara dos Deputados. Brasília, DF.

Das, T. K., \& Teng, B. S. (1998). Between trust and control: Developing confidence in partner cooperation in alliances. Academy of management review, 23(3), 491-512. 
Decreto n. 6.170. (2007, 25 de julho). Dispõe sobre as normas relativas às transferências de recursos da União mediante convênios e contratos de repasse, e dá outras providências. Brasília, DF: Presidência da República. Recuperado de http://www.planalto.gov.br/ccivil_03/_ato2007-2010/2007/decreto/d6170.htm

Decreto n. 8.894. (2016, 3 de novembro). Aprova a Estrutura Regimental e o Quadro Demonstrativo dos Cargos em Comissão e das Funções de Confiança do Ministério do Trabalho e dá outras providências. Brasília, DF: Presidência da República. Recuperado de http://www.planalto.gov.br/ccivil_03/_Ato2015-2018/2016/Decreto/D8894.htm\#art11

Decreto n. 8.180. (2013, 30 de dezembro). Altera o Decreto $n^{\circ} 6.170$, de 25 de julho de 2007, que dispõe sobre as normas relativas às transferências de recursos da União mediante convênios e contratos de repasse. Brasília, DF: Presidência da República. Recuperado de http://www.planalto.gov.br/ccivil_03/_ato2011-2014/2013/decreto/D8180.htm

De Hoog, R. H. (1984). Contracting out for human services: Economic, political, and organizational perspectives. SUNY Press.

Dekker, H. C. (2004). Control of inter-organizational relationships: evidence on appropriation concerns and coordination requirements. Accounting, Organizations and Society, 29(1), 27-49.

Demsetz, H. (1968). Why regulate utilities? The Journal of Law \& Economics, 11(1), 55-65.

Domberger, S., \& Jensen, P. (1997). Contracting out by the public sector: theory, evidence, prospects. Oxford review of economic policy, 13(4), 67-78.

Evans, J. H., \& Patton, J. M. (1983). An economic analysis of participation in the municipal finance officers association certificate of conformance program. Journal of Accounting and Economics, 5, 151-175.

Evans, J. H., \& Patton, J. M. (1987). Signaling and monitoring in public-sector accounting. Journal of Accounting Research, 130-158.

Fávero, L. P., \& Belfiore, P. (2017). Manual de análise de dados: estatística e modelagem multivariada com Excel, SPSS e Stata. São Paulo, SP: Elsevier.

Feltham, G. A. (1968). The value of information. The Accounting Review, 43(4), 684-696.

Fernandez, S. (2005). Accounting for performance in contracting for services: Are successful contractual relationships controlled or managed. In 8th Public Management Research Conference, Los Angeles, California, University of Southern California.

Fine, J., Mareschal, P., Hersh, D., \& Leach, K. (2017). Contracting, performance management, and accountability: Political symbolism versus good governance. Journal of Strategic Contracting and Negotiation, 2055563617698172.

Froud, J., Haslam, C., Johal, S., Shaoul, J., \& Williams, K. (1998). Persuasion without numbers? Public policy and the justification of capital charging in NHS trust hospitals. Accounting, Auditing \& Accountability Journal, 11(1), 99-125. 
Garson, G. D. (2013). Introductory guide to HLM with HLM 7software. Hierarchical linear modeling: Guide and applications.

Gazley, B. (2008). Beyond the contract: The scope and nature of informal governmentnonprofit partnerships. Public administration review, 68(1), 141-154.

Gelman, A., \& Hill, J. (2007). Data analysis using regression and multilevelhierarchical models (Vol. 1). New York, NY, USA: Cambridge University Press.

Gomes, E. C. D. S. (2009). Fundamentos das transferências intergovernamentais. Direito Público, 6(27).

Goulart, S. R. (2015). Transferências voluntárias da união: uma análise de eficiência em municípios mineiros. Dissertação de Mestrado, Universidade FUMEC, Belo Horizonte), 10(1).

Hand, D. J., \& Henley, W. E. (1996). Statistical classification methods in consumer credit scoring: a review. Journal of the Royal Statistical Society: Series A (Statistics in Society), 160(3), 523-541.

Hay, D. A., \& Morris, D. J. (1991). Industrial economics and organization: theory and evidence. Oxford University Press, USA.

Heinrich, C. J., \& Choi, Y. (2007). Performance-based contracting in social welfare programs. The American Review of Public Administration, 37(4), 409-435.

Kramer, R. M., \& Grossman, B. (1987). Contracting for social services: Process management and resource dependencies. Social Service Review, 61(1), 32-55.

Horn, M. J. (1995). The political economy of public administration: Institutional choice in the public sector. Cambridge University Press.

Ingram, R. W. (1984). Economic incentives and the choice of state government accounting practices. Journal of Accounting Research, 126-144.

Johnston, J. M., \& Romzek, B. S. (1999). Contracting and accountability in state Medicaid reform: Rhetoric, theories, and reality. Public Administration Review, 383-399.

Kaplan, R. S., \& Anderson, S. R. (2003). Time-Driven Activity-Based Costing. Available at SSRN 485443.

Kettl, D. F. (2011). Sharing power: Public governance and private markets. Brookings Institution Press.

Klein, B., Crawford, R. G., \& Alchian, A. A. (1978). Vertical integration, appropriable rents, and the competitive contracting process. The Journal of law \& economics, 21(2), 297-326.

Ignarra, R. (2014). Monitoramento de recursos de transferências voluntárias na esfera municipal (Dissertação de Mestrado - Fundação Getúlio Vargas, Rio de Janeiro). 
Ingram, R. W. (1984). Economic incentives and the choice of state government accounting practices. Journal of Accounting Research, 126-144.

Jensen, M. C., \& Meckling, W. H. (2008). Teoria da firma: comportamento dos administradores, custos de agência e estrutura de propriedade. Revista de Administração de Empresas, 48(2), 87-125.

Lecy, J., \& Thornton, J. (2016). What Big Data Can Tell Us About Government Awards to the Nonprofit Sector: Using the FAADS. Nonprofit and Voluntary Sector Quarterly, 45(5), 10521069.

Lecy, J. D., \& Van Slyke, D. M. (2012). Nonprofit sector growth and density: Testing theories of government support. Journal of Public Administration Research and Theory, 23(1), 189214.

Lei Complementar n. 101, de 14 de maio de 2000. (2000, 14 de maio). Estabelece normas de finanças públicas voltadas para a responsabilidade na gestão fiscal e dá outras providências.Brasília, DF: Presidência da República.

Recuperado de http://www.planalto.gov.br/Ccivil_03/leis/LCP/Lcp101.htm

Lei n. 7.998, de 11 de janeiro de 1990. (1990, 11 de janeiro). Regula o Programa do SeguroDesemprego, o Abono Salarial, institui o Fundo de Amparo ao Trabalhador (FAT), e dá outras providências. Brasília, DF: Presidência da República.

Recuperado de http://www.planalto.gov.br/ccivil_03/leis/17998.htm

Lei n. 8.019, de 11 de abril de 1990. (1990, 11 de abril). Altera a legislação do Fundo de Amparo ao Trabalhador (FAT), e dá outras providências. Brasília, DF: Presidência da República. Recuperado de http://www.planalto.gov.br/ccivil_03/leis/18019.htm

Lei n. 13.019, de 31 de julho de 2014. (2014, 31 de julho). Estabelece o regime jurídico das parcerias entre a administração pública e as organizações da sociedade civil, em regime de mútua cooperação, para a consecução de finalidades de interesse público e recíproco, mediante a execução de atividades ou de projetos previamente estabelecidos em planos de trabalho inseridos em termos de colaboração, em termos de fomento ou em acordos de cooperação; define diretrizes para a política de fomento, de colaboração e de cooperação com organizações da sociedade civil. Brasília, DF: Presidência da República. Recuperado de http://www.planalto.gov.br/ccivil_03/_ato2011-2014/2014/lei/l13019.htm

Lei n. 13.024, de 14 de dezembro de 2015. (2015, 14 de dezembro). Altera a Lei no 13.019, de 31 de julho de 2014, "que estabelece o regime jurídico das parcerias voluntárias, envolvendo ou não transferências de recursos financeiros, entre a administração pública e as organizações da sociedade civil, em regime de mútua cooperação, para a consecução de finalidades de interesse público; define diretrizes para a política de fomento e de colaboração com organizações da sociedade civil; institui o termo de colaboração e o termo de fomento. Brasília, DF: Presidência da República. Recuperado de http://www.planalto.gov.br/ccivil_03/_Ato2015-2018/2015/Lei/L13204.htm\#art1

Levy, B., \& Spiller, P. T. (1994). Institutional Foundations of Regulatory Commitment: A Comparative Analysis of Telecommunications Regulation, The. JL Econ. \& Org., 10, 201. 
Lima, F. J., Cirqueira, J. C., Pinto, V. C., \& de Souza, W. A. D. R. (2017). Gerenciamento de Projetos: Um Modelo de Monitoramento e Controle de Projetos Públicos Executados com Recursos de Transferências Voluntárias. Revista de Gestão e Projetos-GeP, 8(1), 102-117.

Llewellyn, K. N. (1931). What price contract?An essay in perspective. The Yale Law Journal, 40(5), 704-751.

Lofrano, R. (2010). Mecanismos de desenvolvimento institucional: programas de apoio aos municípios. In Congresso Consad de Gestão Pública, 1-23.

Lu, J. (2016). Governing diversity: The impact of social heterogeneity on human service delivery. Public Organization Review, 16(2), 153-166.

Marinho, D., Balestro, M., \& Walter, M. (2010). Políticas públicas de emprego no Brasil: avaliação externa do seguro-desemprego. In Ministério do Trabalho e Emprego (Publicações). Recuperado de http://portalfat.mte.gov.br/wpcontent/uploads/2015/09/Avalia\%C3\%A7\%C3\%A3o-Externa-do-Programa-SeguroDesemprego-\%E2\%80\%93-Resumo-Executivo.pdf

McCubbins, M. D., \& Page, T. (1987). A theory of congressional delegation. In Congress: Structure and policy (v. 409, p. 411-413). Cambridge: Cambridge University Press.

McCubbins, M. D., \& Schwartz, T. (1984). Congressional oversight overlooked: Police patrols versus fire alarms. American Journal of Political Science, 165-179.

Mendes, M. J.; Miranda, R. B. \& Cosio, F.B. (2008). Transferências intergovernamentais no Brasil: diagnóstico e proposta de reforma. In Coordenação de Estudos do Senado Federal, 1111.

Meyers, M. K., Glaser, B., \& Donald, K. M. (1998). On the front lines of welfare delivery: Are workers implementing policy reforms? Journal of policy analysis and management, 1-22.

Modell, S. (2001). Performance measurement and institutional processes: a study of managerial responses to public sector reform. Management Accounting Research, 12(4), 437-464.

Moutinho, J. (2016). Descentralização de políticas públicas: análise de variáveis ambientais. In Revista de Administração Pública, 50(1).

Moutinho, J., Kniess, C. T., \& Maccari, E. A. (2013). A influência da gestão de projetos na estratégia de transferências voluntárias de recursos da união para municípios brasileiros: o caso de uma prefeitura de médio porte. Revista Ibero-Americana de Estratégia, 12(1), 181.

Nobel Prize Committee. (2016). Oliver Hart and Bengt Holmström: Contract Theory. Scientific Background on the Sveriges Riksbank Prize in Economic Sciences in Memory of Alfred Nobel.

Ouchi, W. G. (1979). A conceptual framework for the design of organizational control mechanisms. In Readings in Accounting for Management Control (p. 63-82). Springer US. 
Pacheco, R. S. (2004, November). Contratualização de resultados no setor público: a experiência brasileira e o debate internacional. In Congresso Internacional del Clad sobre la Reforma del Estado y de la Administración Pública (v. 9).

Pires Júnior, J. A. M. (2003). Transferências Voluntárias na Caixa de Edgerworth - Sob a Égide da Lei de Responsabilidade Fiscal. (Monografia premiada em $3^{\circ}$ lugar no VIII Prêmio Tesouro Nacional2003, Tópicos Especiais de Finanças Públicas), ESAF, Brasília.

Portaria Interministerial MPOG/MF/CGU n. 507. (2011, 24 de novembro). Estabelece normas para execução do disposto no Decreto no 6.170, de 25 de julho de 2007, que dispõe sobre as normas relativas às transferências de recursos da União mediante convênios e contratos de repasse, revoga a Portaria Interministerial no 127/MP/MF/CGU, de 29 de maio de 2008 e dá outras providências. Brasília, DF: MPOG/MF/CGU. Recuperado de http://portal.convenios.gov.br/legislacao/portarias/portaria-interministerial-n-507-de-24-denovembro-de-2011

Portaria Interministerial MPOG/MF/CGU n. 424. (2016, 30 de dezembro). Estabelece normas para execução do estabelecido no Decreto $n^{\circ} 6.170$, de 25 de julho de 2007, que dispõe sobre as normas relativas às transferências de recursos da União mediante convênios e contratos de repasse, revoga a Portaria Interministerial n ${ }^{\circ}$ 507/MP/MF/CGU, de 24 de novembro de 2011 e dá outras providências. Brasília, DF: MPOG/MF/CGU. Recuperado de http://portal.convenios.gov.br/legislacao/portarias/portaria-interministerial-n-424-de-30-dedezembro-de-2016

Portaria Interministerial MPOG/MF/CGU n. 451. (2017, 18 de dezembro). Altera a Portaria Interministerial $\mathrm{n}^{\circ} 424$, de 30.12.2016, que estabelece normas para execução do Decreto $\mathrm{n}^{\circ}$ 6.170, de 25.06.2007, que dispõe sobre as normas relativas às transferências de recursos da União mediante convênios e contratos de repasse, revoga a Portaria Interministerial $\mathrm{n}^{\circ}$ 507/MP/MF/CGU, de 24.11.2011 e dá outras providências. Brasília, DF: MPOG/MF/CGU. Recuperado de

http://www.mctic.gov.br/mctic/opencms/legislacao/portarias_interministeriais/Portaria_Inter ministerial_MPOG_MF_CGU_n_451_de_18_12_2017.html

Resolução CODEFAT n. 721. (2013, 30 de outubro). Estabelece critérios para distribuição de recursos da ação "Manutenção, Modernização e Ampliação da Rede de Atendimento do Programa Seguro-Desemprego no âmbito do Sistema Nacional de Emprego - SINE”, para execução integrada das ações do Sistema Público de Emprego, Trabalho e Renda, no âmbito do Sistema Nacional de Emprego - Sine, e dá outras providências. Brasília, DF: Codefat. Recuperado de http://portalfat.mte.gov.br/wp-content/uploads/2016/01/Res721.pdf

Resolução CODEFAT n. 722. (2013, 27 de novembro). Altera a Resolução no 721, de 30 de outubro de 2013, que estabelece critérios para distribuição de recursos da ação "Manutenção, Modernização e Ampliação da Rede de Atendimento do Programa Seguro-Desemprego no âmbito do Sistema Nacional de Emprego - Sine", para execução integrada das ações do Sistema Público de Emprego, Trabalho e Renda, no âmbito do Sistema Nacional de Emprego - Sine. Brasília, DF: Codefat. Recuperado de http://portalfat.mte.gov.br/wp-content/uploads/2016/01/Res722.pdf

Resolução Codefat n. 728. (2014, 10 de abril). Altera a Resolução no 721, de 30 de outubro de 2013, que estabelece critérios para distribuição de recursos da ação "Manutenção, 
Modernização e Ampliação da Rede de Atendimento do Programa Seguro-Desemprego no âmbito do Sistema Nacional de Emprego - Sine", para execução integrada das ações do Sistema Público de Emprego, Trabalho e Renda, no âmbito do Sistema Nacional de Emprego - Sine. Brasília, DF: Codefat. Recuperado de http://portalfat.mte.gov.br/wp-content/uploads/2016/02/Res728.pdf

Ribeiro, R. (2010). Orçamento público semi-impositivo para transferências voluntárias: diagnóstico, perspectivas e proposta de mudanças. E-Legis-Revista Eletrônica do Programa de Pós-Graduação da Câmara dos Deputados.

Saindel, J. R. (1991). Resource interdependence: The relationship between public agencies and nonprofit organization. Public Administration Review, 51(6), 543-553.

Sako, M. (1992). Price, quality and trust: Inter-firm relations in Britain and Japan (No. 18). Cambridge University Press.

Salinas, N. S. C. (2008). Avaliação Legislativa no Brasil: um estudo de caso sobre as normas de controle das transferências voluntárias de recursos públicos para entidades do terceiro setor (Dissertação de Mestrado, Faculdade de Direito, Universidade de São Paulo). Recuperado de www.teses.usp.br

Sandfort, J. (1999). The structural impediments to human service collaboration: Examining welfare reform at the front lines. Social Service Review, 73(3), 314-339.

Savas, E. S. (1977). An empirical study of competition in municipal service delivery. Public Administration Review, 37(6), 717-724.

Scott, W. R. (2009). Financial accounting theory (v. 2, n. 0, p. 0). Upper Saddle River, NJ: Prentice hall.

Siddiqi, N. (2006). Credit risk scorecards. Developing and Implementing Intelligent Credit Scoring. In SAS Institute., 1-13

Silva, C. A. T., Marinho, D. N. C., Walter, M. I. M. T., \& de Melo Souza, L. Estudo de Custos do Sistema Nacional de Emprego-Sine. Recuperado de http://portalfat.mte.gov.br/wpcontent/uploads/2016/02/Estudo-de-Custos-do-Sistema-Nacional-de-Emprego-SINE.pdf

Silva, C. L. D., \& Saes, M. S. M. (2007). Governance structure and transaction cost: relationship between strategy and asset specificity. Nova economia, 17(3), 443-468.

Smith, K. G., Carroll, S. J., \& Ashford, S. J. (1995). Intra-and interorganizational cooperation: Toward a research agenda. Academy of Management journal, 38(1), 7-2

Smith, M. (2008). Research methods in accounting. Sage.

Smith, Steven Rathgeb, and Michael Lipsky. (1993). Non-Profits For Hire: The Welfare State in the Age of Contracting. Cam- bridge, MA: Harvard University Press

Smith, S. R., \& Smyth, J. (1996). Contracting for services in a decentralized system. Journal of Public Administration Research and Theory, 6(2), 277-296. 
Soares, M. M., \& Melo, B. G. D. (2016). Condicionantes políticos e técnicos das transferências voluntárias da União aos municípios brasileiros. Revista de Administração Pública, 50(4), 539562.

Souza, C. T. G. D. (2013). Desempenho comparativo dos estados federados na captação de recursos de transferências voluntárias da União, no período 2003-2011. In Congresso Consad de Gestão Pública, 1-35.

Suárez, D. F. (2010). Collaboration and professionalization: The contours of public sector funding for nonprofit organizations. Journal of Public Administration Research and Theory, 21(2), 307-326.

Tamura, E., y Robótica, G. D. A., Busquets-Mataix, J. V., \& Campoy, A. M. (2007). Towards predictable, high-performance memory hierarchies in fixed-priority preemptive multitasking real-time systems. RTNS'07, 13, 75 .

Tomkins, C. (2001). Interdependencies, trust and information in relationships, alliances and networks. Accounting, organizations and society, 26(2), 161-191.

Trezza, V. M. (2007). O termo de parceria como instrumento de relação público/privado sem fins lucrativos: o difícil equilíbrio entre flexibilidade e controle (Dissertação de Mestrado). Escola de Administração Pública, Fundação Getúlio Vargas, São Paulo.

Tribunal de Contas da União. (2016). Convênios e outros contratos de repasse. Recuperado de http://portal.convenios.gov.br/images/_Conv\%C3\%AAnios_e_outros_repasses_6\%C2\%AA_ edi\%C3\%A7\%C3\%A3o.pdf

Wallin, B. A. (1997). The need for a privatization process: Lessons from development and implementation. Public Administration Review, 11-20.

Watts, R. L., \& Zimmerman, J. L. (1986). Positive Accounting Theory.

Williamson, O. E. (1971). The vertical integration of production: market failure considerations. The American Economic Review, 61(2), 112-123.

Williamson, O. E. (1975). Markets and hierarchies. New York, 26-30.

Williamson, O. E. (1976). Franchise bidding for natural monopolies-in general and with respect to CATV. The Bell Journal of Economics, 73-104.

Williamson, O. E. (1979). Transaction-cost economics: the governance of contractual relations. The Journal of Law \& Economics, 22(2), 233-261

Williamson, O. E. (1981). The economics of organization: The transaction cost approach. American Journal of Sociology, 548-577.

Williamson, O. E. (1983). Credible commitments: Using hostages to support exchange. The American Economic Review, 73(4), 519-540. 
Williamson, O. E. (1985). The economic institutions of capitalism: firms, markets, relational contracting. Free Press.

Williamson, O. E. (1988). Corporate finance and corporate governance. The journal of finance, 43(3), 567-591.

Williamson, O. E. (1991). Comparative economic organization: The analysis of discrete structural alternatives. Administrative science quarterly, 269-296.

Williamson, O. E. (2005). The economics of governance. The American Economic Review, 95(2), 1-18.

Williamson, O. E., \& Masten, S. (1999). The economics of transaction costs. Wooldridge, J. M. (2010). Econometric analysis of cross section and panel data. MIT press.

Witesman, E. M., \& Fernandez, S. (2013). Government contracts with private organizations: Are there differences between nonprofits and for-profits?Nonprofit and Voluntary Sector Quarterly, 42(4), 689-715.

Van Slyke, D. M. (2002). The public management challenges of contracting with nonprofits for social services. International Journal of Public Administration, 25(4), 489-517.

Van Slyke, D. M. (2003). The mythology of privatization in contracting for social services. Public Administration Review, 63(3), 296-315.

Zylbersztajn, D. (1995). Estruturas de governança e coordenação do agribusiness: uma aplicação da nova economia das instituições.

Zimmerman, J. L. (1977). The municipal accounting maze: An analysis of political incentives. Journal of Accounting Research, 107-144.

Zucker, L. G. (1986). Production of trust: Institutional sources of economic structure, 18401920. Research in organizational behavior. 


\section{APÊNDICE A - Apectos legais e normativos das Transferência Voluntárias}

Conforme define a Lei Complementar 101 de 2000 (a partir deste ponto, Lei de Responsabilidade Fiscal - LRF) no seu artigo 25, entende-se como Transferência Voluntária.

A entrega de recursos correntes ou de capital a outro ente da Federação, a título de cooperação, auxílio ou assistência financeira, que não decorra de determinação constitucional, legal ou os destinados ao Sistema Único de Saúde.

De acordo com o artigo $1^{\circ}$, $\S 1^{\circ}$, I, do Decreto 6.170 de 2007 (atualizado pelo Decreto 8.180 de 2013), convênio é um acordo, ajuste ou qualquer outro instrumento que discipline a transferência de recursos financeiros de dotações consignadas nos Orçamentos Fiscal e da Seguridade Social da União e tenha como partícipe, de um lado, órgão ou entidade da administração pública federal, direta ou indireta, e, de outro lado, órgão ou entidade da administração pública estadual, distrital ou municipal, direta ou indireta, ou ainda, entidades privadas sem fins lucrativos, visando à execução de programa de governo, envolvendo a realização de projeto, atividade, serviço, aquisição de bens ou evento de interesse recíproco, em regime de mútua cooperação.

De uma maneira geral, a legislação que atualmente dispõe sobre as transferências voluntárias no âmbito federal é o Decreto 6.170 de 2007, regulamentado pelas Portarias Interministeriais 507/2011, 424/2016 e 451/2017 dos Ministérios do Planejamento, Orçamento e Gestão, da Fazenda e Transparência (Controladoria Geral da União - CGU). Esse decreto também institui o Sistema de Gestão de Convênios e Contratos de Repasse (Siconv) e o Portal de Convênios do Governo central.

Vale destacar que, a partir de 2016, entrou em vigor o Marco Regulatório das Organizações da Sociedade Civil (MROSC), por meio da Lei 13.019 de 2014 (alterada pela Lei 13.204 de 2015) que versa sobre as parcerias entre a administração pública e as organizações da sociedade civil e estabelece as normas de transferências voluntárias entre as duas instituições.

Dessa maneira, o Decreto 6.170 de 2007 (atualizado pelo Decreto 8.180 de 2013) definiu aspectos relacionados às transferências voluntárias regulamentandoConvênios, contratos de repasse e termos de execução descentralizada celebrados pelos órgãos e entidades da administração pública federal com órgãos ou entidades públicas ou privadas sem fins lucrativos, para a execução de programas, projetos e atividades que envolvam a transferência de recursos 
ou a descentralização de créditos oriundos dos Orçamentos Fiscal e da Seguridade Social da União.

As dotações orçamentárias destinadas aos convênios são alocadas ao Orçamento da União de duas maneiras: por (1) contemplação nominal do Estado, do município ou da entidade privada sem fim lucrativo por meio da proposta do Executivo ou de emenda ao Orçamento da União por deputado federal ou senador ou; (2) não contemplação explícita, mas com programa específico destinando recursos para a região onde se localiza o pretendente e prevê sua aplicação por meio de órgão ou entidade estadual, municipal ou não governamental (TCU, 2016).

Para que o interessado em firmar um convênio com o governo central receba o recurso, existem duas formas: (1) por meio da elaboração de uma proposta diretamente ao ministério ou à entidade que disponha de recursos aplicáveis ao objeto pretendido e (2) por demanda do próprio ministério ou entidade federal ao detectar necessidades locais ou de implementação de programas federais na região.

Um convênio envolve quatro fases: (1) proposição; (2) celebração e formalização; (3) execução; e (4) prestação de contas. A seguir serão apresentadas as principais características de cada uma dessas fases:

\section{d) Proposição}

Essa fase é subdivida em 5 etapas, quais sejam: (1) Identificação das áreas prioritárias; (2) Chamamento público; (3) Credenciamento e cadastramento de entes e entidades; (4) Inclusão da proposta e do plano de trabalho no Siconv; (5) Projeto básico e termo de referência.

Na etapa 1, são avaliadas as necessidades existentes na comunidade que necessitam atenção do Poder Público. Após identificadas as carências e prioridades locais, cabe ao interessado em firmar o convênio buscar os recursos para efetuar o projeto no órgão ou entidade apropriados. Cabe ressaltar que como os recursos disponíveis são escassos, é primordial que o interessado elabore uma proposta em consonância com os programas federais existentes, conforme aponta TCU (2016).

Com o objetivo de selecionar a melhor proposta, atrair entidades com capacidade técnica e operacional e bem como atender aos princípios da administração pública, os órgãos federais 
realizam o Chamamento Público, segunda etapa da fase de Proposição. Destaca-se que essa fase é opcional para os convênios celebrados com os entes federados e, somente eles. Portanto, se o interessado se tratar de uma entidade privada sem fins lucrativos, o chamamento público é uma etapa obrigatória, conforme estabelece a Portaria Interministerial número 507 de 2011 (PI 507/2011).

Para que o proponente manifeste a intenção de celebrar o convênio com o governo central, fazse necessário a apresentação de uma proposta de trabalho no Siconv. Para isso, é indispensável que o interessado esteja credenciado e cadastrado no Portal de Convênios, respeitados todos os requisitos legais e normativos em vigência (etapa 3 ).

Na quarta etapa, o interessado cadastra seu projeto básico no Siconv. Para isso, devem ser identificados aspectos relacionados à contrapartida, valores da proposta, contrapartida financeira, em bens ou em serviços, modalidade da transferência, descrição do objeto, datas importantes, documentos comprobatórios da capacidade técnica e operacional (TCU, 2016).

No projeto básico, o proponente ainda informa as metas do cronograma físico de execução, o cronograma de desembolso e o plano de aplicação detalhado que deve conter informações sobre o tipo de despesa, código orçamentário e natureza da despesa. Após a inserção do projeto no Siconv, a proposta é enviada para análise do ente concedente. A aprovação do projeto básico implicaráa adequação do plano de trabalho (TCU, 2016).

O Tribunal de Contas da União (TCU, 2016) elencou as irregularidades e falhas mais frequentes na fase de Proposição: (i) plano de trabalho pouco detalhado; (ii) metas insuficientemente descritas, quantitativa e qualitativamente; (iii) caracterização insuficiente da situação de carência dos recursos; (iv) projeto básico incompleto e/ou com informações insuficientes; (v) ausência de projeto básico; (vi) falta de comprovação de existência de contrapartida (orçamentária e financeira); e (vii) orçamento sub ou superestimados.

\section{e) Celebração e Formalização do Convênio}

A demonstração do cumprimento de requisitos para a celebração de convênios deve ser realizada tanto pelos entes federados e respectivas administrações indiretas quanto pelas entidades privadas sem fins lucrativos, considerando aspectos fiscais, de licença ambiental, regularidades do INSS e FGTS etc., aplicáveis a cada um conforme determinação legal, bem 
como as exigências específicas do programa e do órgão responsável pela transferência (TCU, 2016).

Após a aprovação e celebração do convênio, é dada publicidade a todos os atos referidos à sua operacionalização, bem como a abertura da conta corrente indicada pelo convenente.

\section{f) Execução do convênio}

Essa fase está relacionada à execução física e execução financeira. A execução financeira abrange diversos procedimentos, tais como a regulamentação de conta bancária específica; o pagamento de despesas, respeitado todos os seus estágios; e, quando aplicável, o pagamento de despesas por meio de Ordem Bancária de Transferência Voluntária (OBTV).

A execução física abrange procedimentos relacionados a procedimentos licitatórios, contratação de terceiros, execução de contratos de obras, bens e serviços. Salienta-se que tanto a execução física quanto execução financeira estão submetidas a uma série de dispositivos legais e devem ser registrados, todos os seus procedimentos, no Siconv.

Nessa linha, o Tribunal de Contas da União (TCU, 2016) reitera que o sucesso do convênio depende essencialmente de três fatores: seguir o Plano de Trabalho e as normas de administração financeira e orçamentária e registrar todos os atos relativos à execução do convênio no Siconv (TCU, 2016).

Apesar de um planejamento criterioso ser um dos principais determinantes para o êxito do convênio, é possível que o convenente não consiga executar o convênio nos moldes do plano de trabalho, seja por insuficiência de recursos, seja porque o objeto não é mais considerado prioritário na localidade prevista, e isso só será observado na fase de execução. Neste caso, o gestor do convenente deve contatar o órgão concedente e renegociar os termos previstos no plano de trabalho. Conforme as normas vigentes, a utilização de recursos para finalidade diversa da pactuada implica irregularidade grave.

Assim, o Tribunal de Contas aponta as irregularidades mais frequentes na fase de execução: (i) utilização dos recursos para o pagamento de outras despesas do convenente; (ii) transferência de recursos de conta específica para outras contas correntes; (iii) não aplicação ou não comprovação de contrapartida; (iv) alteração do objeto de convênio sem autorização prévia do órgão concedente; (v) pagamento sem o atesto que comprove o recebimento do objeto; (vi) uso 
dos rendimentos da aplicação financeira para finalidades diferentes das previstas no plano de trabalho; (vii) não devolução do saldo financeiro ao concedente; (viii) realização de despesas fora da vigência do convênio; (ix) falta de divulgação da licitação; (x) aquisição direta de bens sem licitação; (xi) inobservância dos prazos de recursos; (xii) dispensa de licitação sob alegação de emergência; (xiii) ausência e documentos de habilitação das empresas participantes; (xiv) aquisição de bens ou execução de obras com preços superiores aos praticados no mercado; (xv) pagamentos sem cobertura contratual etc. (TCU, 2016).

\section{g) Prestação de contas}

Conforme evidenciado na fase de Execução, todos os atos relativos ao convênio celebrado devem ser registrados no Siconv. Essa obrigatoriedade tornou possível que a prestação de contas dos recursos repassados fosse realizada simultaneamente à execução.

Ainda na fase de execução, uma importante etapa da prestação de contas é realizada, a geração de relatórios: beneficiários, receita/despesa do PT, treinados e capacitados, bens produzidos ou construídos, bens adquiridos, bens e serviços de obras, despesas administrativas, físico do plano de trabalho; financeiro do plano de trabalho; pagamentos realizados, documentos de liquidação incluídos, bens e serviços da contrapartida e serviços contratados.

A prestação de contas deve ser apresentada exclusivamente pelo Siconv. A apresentação por meio físico, apenas, pode acarretar abertura de tomadas de contas especial (TCE). Vale salientar que outros atos podem resultar na rejeição das contas e instauração da TCE.

A TCE é processada no TCU após exauridas todas as providências das autoridades administrativas repassadora. Os responsáveis que estiverem suas contas consideradas irregulares poderão sofrer consequências graves que variam de multa a instauração de processo penal. 
APÊNDICE B - Dicionário de variáveis

\begin{tabular}{|c|c|c|c|c|}
\hline Nome da variável & Descricão & Tine de variáyel & Categorias/Fscola de nrecis̃̃ & Classificacão \\
\hline cumprimentodocontrato & contrato: cumprido integralmente ou parcialmente; não cumprido & Categórica & Binária & Chave \\
\hline graudecumprimento & contrato: cumprido integralmente; não cumprido; cumprido parcialmente & Categórica & Policotômica & Chave \\
\hline escolhainstitucional & tipo de convenente: entidade privada; estado; município & Categórica & Policotômica & Chave \\
\hline ind_ajustesPT & Existem ajustes no plano de trabalho: sim; não & Categórica & Binária & Execução \\
\hline indbenscomrecursodoconvenio & gastos com bens utilizando recursos do convênio: sim; não & Categórica & Binária & Execução \\
\hline inddespesaadmconvenio & gastos com despesas administrativas utilizando recursos do convênio: sim; não & Categórica & Binária & Execução \\
\hline indobrascomrecursodoconvenio & gastos com obras utilizando recursos do convênio: sim; não & Categórica & Binária & Execução \\
\hline indoutroscomrecursodoconveni & outros gastos utilizando recursos do convênio: sim; não & Categórica & Binária & Execução \\
\hline indservicoscomrecursodoconve & gastos com serviços utilizando recursos do convênio: sim; não & Categórica & Binária & Execução \\
\hline indtotalembens & gastos totais com bens: sim; não & Categórica & Binária & Execução \\
\hline indtotalemdespesaadministrativa & gastos totais com despesas administrativas: sim; não & Categórica & Binária & Execução \\
\hline indtotalemobras & gastos totais com obras: sim; não & Categórica & Binária & Execução \\
\hline $\begin{array}{l}\text { indtotalemoutros } \\
\end{array}$ & outros gastos totais: sim; não & Categórica & Binária & Execução \\
\hline indtotalemservicos & gastos totais com serviços: sim; não & Categórica & Binária & Execução \\
\hline indtotalemtributos & gastos totais com tributos: sim; não & Categórica & Binária & Execução \\
\hline indtributoscomrecursodoconve & gastos com tributos utilizando recursos do convênio: sim; não & Categórica & Binária & Execução \\
\hline 1_contrapartida & logaritmo do valor da contrapartida & Métrica & Contínua & Cadastro \\
\hline 1_valoradesembolsar & logaritmo do valor a desembolsar & Métrica & Contínua & Cadastro \\
\hline 1_valorconveniado & logaritmo do valor conveniado & Métrica & Contínua & Cadastro \\
\hline 1_valordorendimento & logaritmo do valor do rendimento & Métrica & Contínua & Execução \\
\hline 1_valorliberado & logaritmo do valor liberado & Métrica & Contínua & Execução \\
\hline servicos_ind & relatório de serviços apresentado & Categórica & Binária & Execução \\
\hline ind_rejeição_serviços & relatório de serviços rejeitado pelo menos uma vez & Categórica & Binária & Execução \\
\hline bscontrapartida_ind & relatório de bens e serviços da contrapartida apresentado & Categórica & Binária & Execução \\
\hline ind_rejeição_contrapartida & relatório de bens e serviços da contrapartida rejeitado pelo menos uma vez & Categórica & Binária & Execução \\
\hline bensadquiridos_ind & relatório de bens adquiridos apresentado & Categórica & Binária & Execução \\
\hline ind_rejeição_bensadquiridos & relatório de bens adquiridos rejeitado pelo menos uma vez & Categórica & Binária & Execução \\
\hline contruidos_ind & relatório de itens construídos apresentado & Categórica & Binária & Execução \\
\hline ind_rejeição_contruidos & relatório de itens construídos já rejeitado pelo menos uma vez & Categórica & Binária & Relatórios \\
\hline beneficiarios_ind & relatório de beneficiários apresentado & Categórica & Binária & Relatórios \\
\hline ind_rejeição_beneficiarios & relatório de beneficiários já rejeitado & Categórica & Binária & Relatórios \\
\hline documentos_ind & relatório de documentos de liquidação apresentado & Categórica & Binária & Relatórios \\
\hline
\end{tabular}


Ilustração 7: Dicionário de variáveis

$$
\text { Descrição }
$$

Nome da variável

nd_rejeição_documentos

financeiro_ind

ind_rejeição_financeiro

receitadespesa_ind

ind_rejeição_receitadespesa

pagamentos_ind

ind_rejeição_pagamentos

$$
\text { fisico_ind }
$$

ind_rejeição_fisico

treinados_ind

quantidadederepasses

1_repasse1

1_repasse2

1 repasse 3

1_repasse4

1_repasse5

1_repasse6

quantidadedeetapas

parcelasdasetapas

servicosemgeral

intermediacaodemaodeobra

seguro-desemprego

qualificaca

$$
\text { familias }
$$

beneficiarios(empessoas)

capacitacao(econscientizcao)dosbeneficiarios(emcursos)

capacitacaodeagentesdedesenvolvimento/credito(empessoas) espacofuncionalfisico estruturacaodeees assessoriadeees

bancosfundoscomunitarioscriaca

bancosfunfoscomunitariosassess

realizacaoparticipacaodefeiras relatório de documentos de liquidação rejeitado pelo menos uma vez relatório financeiro do plano de trabalho apresentado

relatório financeiro do plano de trabalho já rejeitado pelo menos uma vez

relatório de receita e despesa do plano de trabalho apresentado

relatório de receita e despesa do plano de trabalho já rejeitado pelo menos uma vez relatório de pagamentos apresentado relatório de pagamentos rejeitado pelo menos uma vez

$$
\text { relatório físico apresentado }
$$

relatório físico rejeitado pelo menos uma vez relatório de treinados apresentado

$$
\text { quantidade de repasses }
$$

logaritmo do valor do primeiro repasse

logaritmo do valor do segundo repasse

logaritmo do valor do terceiro repasse

logaritmo do valor do quarto repasse

logaritmo do valor do quinto repasse

logaritmo do valor do sexto repasse

quantidade de etapas de execução das metas previstas no plano de trabalho

valor monetário atribuído a cada etapa de execução do plano de trabalho

quantidade de pessoas atendidas para serviços gerais

quantidade de pessoas atendidas para intermediação de mão-de-obra

quantidade de pessoas atendidas para habilitação do seguro-desemprego quantidade de pessoas atendidas para qualificação quantidade de famílias beneficiárias quantidade de pessoas beneficiárias

quantidade de cursos para capacitação para beneficiários quantidade de agentes de desenvolvimento ou crédito capacitados quantidade de espaços funcionais e físicos

quantidade de empreendimentos econômicos solidários estruturados quantidade de empreendimentos econômicos solidários assessorados quantidade de bancos/fundos criados

quantidade de bancos/fundos assessorados

quantidade de participação/realização de feiras

\begin{tabular}{|c|c|c|}
\hline Tipo de variável & Categorias/Escala de precisão & Classificação \\
\hline Categórica & Binária & Relatórios \\
\hline Categórica & Binária & Relatórios \\
\hline Categórica & Binária & Relatórios \\
\hline Categórica & Binária & Relatórios \\
\hline Categórica & Binária & Relatórios \\
\hline Categórica & Binária & Relatórios \\
\hline Categórica & Binária & Relatórios \\
\hline Categórica & Binária & Relatórios \\
\hline Categórica & Binária & Relatórios \\
\hline Categórica & Binária & Relatórios \\
\hline Métrica & Discreta & Execução \\
\hline Métrica & Contínua & Execução \\
\hline Métrica & Contínua & Execução \\
\hline Métrica & Contínua & Execução \\
\hline Métrica & Contínua & Execução \\
\hline Métrica & Contínua & Execução \\
\hline Métrica & Contínua & Execução \\
\hline Métrica & Discreta & Execução \\
\hline Métrica & Contínua & Execução \\
\hline Métrica & Discreta & Execução \\
\hline Métrica & Discreta & Meta \\
\hline Métrica & Discreta & Meta \\
\hline Métrica & Discreta & Meta \\
\hline Métrica & Discreta & Meta \\
\hline Métrica & Discreta & Meta \\
\hline Métrica & Discreta & Meta \\
\hline Métrica & Discreta & Meta \\
\hline Métrica & Discreta & Meta \\
\hline Métrica & Discreta & Meta \\
\hline Métrica & Discreta & Meta \\
\hline Métrica & Discreta & Meta \\
\hline Métrica & Discreta & Meta \\
\hline Métrica & Discreta & Meta \\
\hline & & and \\
\hline
\end{tabular}

continua $(2 / 4)$ 
Ilustração 7: Dicionário de variáveis

\begin{tabular}{|c|c|c|c|c|}
\hline Nome da variável & Descrição & Tipo de variável & Categorias/Escala de precisão & Classificação \\
\hline encontrodeacompanhamentoeavaliac & $\begin{array}{l}\text { quantidade de encontros/congressos para acompanhamento e avaliação previstos no } \\
\text { contrato }\end{array}$ & Métrica & Discreta & Meta \\
\hline pessoaformadaemes & quantidade de pessoas formadas em Economia Solidária & Métrica & Discreta & Meta \\
\hline intangiveisparaees1 naoquantas & existência de intangíveis previstos no contrato & Categórica & Binária & Meta \\
\hline aqusicaodeimobilizadoparaees $1 \mathrm{n}$ & $\begin{array}{l}\text { quantidade de imobilizados adquiridos para os empreendimentos econômicos } \\
\text { solidários }\end{array}$ & Métrica & Discreta & Meta \\
\hline basesregionaiseestaduaismanuten & quantidade de bases regionais e estaduais para administração/manutenção do contrato & Métrica & Discreta & Meta \\
\hline quantidadededesembolsos & quantidade de desembolsos totais previstos no contrato & Métrica & Discreta & Execução \\
\hline quantidade_termosaditivos & quantidade de termos aditivos realizados no contrato & Métrica & Discreta & Execução \\
\hline ind_prorrogação & contrato foi prorrogado: sim; não & Categórica & Binária & Execução \\
\hline quantidade_prorrogações & quantidades de vezes que o contrato foi prorrogado & Métrica & Discreta & Execução \\
\hline mediadediasprorrogados & média de dias prorrogados do contrato & Métrica & Contínua & Execução \\
\hline ind_parecer_rejeição & contrato apresentou parecer de rejeição: sim; não & Categórica & Binária & Parecer \\
\hline ind_parecer_retificação & contrato apresentou parecer de retificação: sim; não & Categórica & Binária & Parecer \\
\hline ind_parecer_ressalvas & contrato apresentou parecer com ressalvas: sim; não & Categórica & Binária & Parecer \\
\hline ind_estornoinadimplência & contrato apresentou estorno de inadimplência: sim; não & Categórica & Binária & Parecer \\
\hline ind_parecer_aprovação & contrato apresentou estorno de inadimplência: sim; não & Categórica & Binária & Parecer \\
\hline ind_parecer_financeiro & contrato apresentou parecer de aprovação: sim; não & Categórica & Binária & Parecer \\
\hline ind_parecer_resgate & contrato apresentou parecer de resgate: sim; não & Categórica & Binária & Parecer \\
\hline ind_tce & contrato possui processo de tomada de contas especial: sim; não & Categórica & Binária & Parecer \\
\hline ind_parecergeral & contrato apresentou parecer geral: sim; não & Categórica & Binária & Parecer \\
\hline ind_publicações & contrato evidenciou alguma publicação: sim; não & Categórica & Binária & Parecer \\
\hline ind_devoluçãorecurso & contrato evidenciou alguma devolução de recurso: sim; não & Categórica & Binária & Parecer \\
\hline ind_contratoslicitação & existem subcontratos (licitação, dispensa ou exigibilidade): sim; não & Categórica & Binária & Execução \\
\hline quantidade_contratos_licitação & quantidade de subcontratos realizados & Métrica & Discreta & Execução \\
\hline ind_projeto & contrato evidencia o plano de trabalho: sim; não & Categórica & Binária & Cadastro \\
\hline PT_contrapartida & contrato apresentou alguma alteração relacionada à contrapartida: sim; não & Categórica & Binária & Execução \\
\hline PT_cronofisico & contrato apresentou alguma alteração relacionada ao cronograma físico: sim; não & Categórica & Binária & Execução \\
\hline PT_plano & contrato apresentou alguma alteração relacionada ao plano de execução: sim; não & Categórica & Binária & Execução \\
\hline PT_desembolso & contrato apresentou alguma alteração relacionada ao desembolso: sim; não & Categórica & Binária & Execução \\
\hline PT_prazo & contrato apresentou alguma alteração relacionada ao prazo: sim; não & Categórica & Binária & Execução \\
\hline PT_metas & contrato apresentou alguma alteração relacionada às metas: sim; não & Categórica & Binária & Execução \\
\hline
\end{tabular}


Ilustração 7: Dicionário de variáveis

\begin{tabular}{|c|c|c|c|c|}
\hline Nome da variável & Descrição & Tipo de variável & Categorias/Escala de precisão & Classificação \\
\hline PT_remanejamento & $\begin{array}{l}\text { contrato apresentou alguma alteração relacionada ao remanejamento de recursos: sim; } \\
\text { não }\end{array}$ & Categórica & Binária & Execução \\
\hline PT_saldoremanescente & contrato apresentou alguma alteração relacionada ao saldo remanescente: sim; não & Categórica & Binária & Execução \\
\hline PT_siconv & contrato apresentou alguma alteração relacionada ao SICONV: sim; não & Categórica & Binária & Execução \\
\hline PT_outros & contrato apresentou alguma alteração relacionada a outros assuntos: sim; não & Categórica & Binária & Execução \\
\hline mudança_contratual & contrato apresentou alguma alteração no plano de trabalho: sim; não & Categórica & Binária & Execução \\
\hline quantidademudançascontratuais & quantidade de alterações contratuais & Métrica & Discreta & Execução \\
\hline 1_totalembens & logaritmo do valor total gasto em bens & Métrica & Contínua & Execução \\
\hline 1_totalembensrecursodoconvenio & logaritmo do valor total gasto em bens com recursos do convênio & Métrica & Contínua & Execução \\
\hline 1_totalemdespesaadministrativa & logaritmo do valor total gasto em despesas administrativas & Métrica & Contínua & Execução \\
\hline 1_totaladministrativarecurso & logaritmo do valor total gasto em despesas administrativas com recursos do convênio & Métrica & Contínua & Execução \\
\hline 1_totalemobras & logaritmo do valor total gasto em obras & Métrica & Contínua & Execução \\
\hline 1_totalobrasrecursodoconvenio & logaritmo do valor total gasto em obras com recursos do convênio & Métrica & Contínua & Execução \\
\hline 1_totaloutros & logaritmo do valor total gasto em outros & Métrica & Contínua & Execução \\
\hline 1_totaloutrosrecursodoconveni & logaritmo do valor total gasto em outros com recursos do convênio & Métrica & Contínua & Execução \\
\hline 1_totalemservicos & logaritmo do valor total gasto em serviços & Métrica & Contínua & Execução \\
\hline 1_totalservicosrecursodoconve & logaritmo do valor total gasto em serviços com recursos do convênio & Métrica & Contínua & Execução \\
\hline 1_totalemtributos & logaritmo do valor total gasto em tributos & Métrica & Contínua & Execução \\
\hline 1_tempodecontratoemdias & logaritmo do tempo do contrato em dias & Métrica & Contínua & Execução \\
\hline tempodecontratoemdias & tempo de vigência do contrato em dias & Métrica & Discreta & Execução \\
\hline tema & $\begin{array}{c}\text { objetivo principal do contrato: qualificação, sine, economia solidária, microcrédito, } \\
\text { pesquisa }\end{array}$ & Categórica & Policotômica & Cadastro \\
\hline secretaria & secretaria responsável pela assinatura, controle e monitoramento & Categórica & Binária & Cadastro \\
\hline disponibilidade & (contrapartida/valorliberado) multiplicado por 100 & Métrica & Contínua & Cadastro \\
\hline coorte, cohort ou safra & início da vigência do contrato & Categórica & Policotômica & Cadastro \\
\hline
\end{tabular}


APÊNDICE C - Estatísticas descritivas \& Análises exploratórias e confirmatórias

\section{1) Estatísticas descritivas}

Tabela 8: Relação entre grau de cumprimento dos contratos finalizados e a cohort (em \%)

\begin{tabular}{|c|c|c|c|c|}
\hline \multirow{2}{*}{ Cohort } & \multicolumn{3}{|c|}{ Grau de cumprimento } & \multirow{2}{*}{ Total } \\
\cline { 2 - 4 } & Integralmente & Parcialmente & Não cumprido & \\
\hline 2008 & 48.2 & 26.5 & 25.3 & 100 \\
\hline 2009 & 56.0 & 18.3 & 25.7 & 100 \\
\hline 2010 & 47.8 & 34.8 & 17.4 & 100 \\
\hline 2011 & 20.7 & 27.6 & 51.7 & 100 \\
\hline 2012 & 20.7 & 32.2 & 47.1 & 100 \\
\hline 2013 & 38.5 & 15.4 & 46.2 & 100 \\
\hline 2014 & 0.0 & 100.0 & 0.0 & 100 \\
\hline 2015 & 0.0 & 0.0 & 100.0 & 100 \\
\hline Total & $\mathbf{4 3 . 2}$ & $\mathbf{2 7 . 6}$ & $\mathbf{2 9 . 3}$ & $\mathbf{1 0 0}$ \\
\hline
\end{tabular}

Tabela 9: Relação entre grau de cumprimento dos contratos finalizados e a escolha institucional

\begin{tabular}{|c|c|c|c|c|}
\hline \multirow{2}{*}{ Escolha institucional } & \multicolumn{3}{|c|}{ Grau de cumprimento } & \multirow{2}{*}{ Total } \\
\cline { 2 - 5 } & Integralmente & Parcialmente & Não cumprido & \\
\hline Entidade privada & 51.3 & 23.6 & 25.2 & 100 \\
\hline Estado & 21.2 & 36.4 & 42.4 & 100 \\
\hline Município & 35.2 & 38.7 & 26.1 & 100 \\
\hline Total & $\mathbf{4 3 . 2}$ & $\mathbf{2 7 . 6}$ & $\mathbf{2 9 . 3}$ & $\mathbf{1 0 0}$ \\
\hline
\end{tabular}




\section{2) Resultados das Técnicas Exploratórias}

a) Resultados da Análise de Correspondência Múltipla - Grupo de indicador, grau de cumprimento do contrato e escolha institucional, total (Tabela 10)

Tabela: Associação entre Grupo de indicador, grau de cumprimento do contrato e escolha institucional

\begin{tabular}{|c|c|c|c|c|}
\hline Grau/Escolha & Entidade Privada & Estado & Município & Total \\
\hline Integralmente & 163 & 14 & 50 & 227 \\
\hline Não & 75 & 24 & 55 & 154 \\
\hline Parcialmente & 80 & 28 & 37 & 145 \\
\hline Total & 318 & 66 & 142 & 526 \\
\hline \multicolumn{5}{|c|}{ Pearson chi2(4) $=29.3378$ Pr $=0.000$} \\
\hline Grau/Grupo de Indicador & Parcial baixo & Parcial médio & Total & Total \\
\hline Integralmente & 32 & 27 & 168 & 227 \\
\hline Não & 107 & 23 & 24 & 154 \\
\hline Parcialmente & 76 & 33 & 36 & 145 \\
\hline Total & 215 & 83 & 228 & 526 \\
\hline \multicolumn{5}{|c|}{ Pearson chi2 $(4)=170.1840 \quad \operatorname{Pr}=0.000$} \\
\hline Escolha/Grupo de Indicador & Parcial baixo & Parcial médio & Total & Total \\
\hline Entidade Privada & 82 & 55 & 181 & 318 \\
\hline Estado & 41 & 8 & 17 & 66 \\
\hline Município & 92 & 20 & 30 & 142 \\
\hline Total & 215 & 83 & 228 & 526 \\
\hline \multicolumn{5}{|c|}{ Pearson chi2 $(4)=80.5474 \quad \operatorname{Pr}=0.000$} \\
\hline
\end{tabular}

\begin{tabular}{|cccc|}
\hline \multicolumn{4}{|c|}{ Multiple/Joint correspondence analysis } \\
Number of obs & 526 & & \\
Total inertia & 0.17748363 & \\
Number of axes & 2 & & \\
\multicolumn{4}{c}{ Method: Burt/adjusted inertias } \\
Dimension & Principal inertia & Percent & Cumul percent \\
dim 1 & 0.1543295 & 86.95 & 86.95 \\
$\operatorname{dim} 2$ & 0.004839 & 2.73 & 89.68 \\
$\operatorname{dim} 3$ & 0.0001085 & 0.06 & 89.74 \\
Total & 0.1774836 & 100 & \\
\hline
\end{tabular}


b) Resultados da Análise de Correspondência Múltipla - Grupo de indicador, grau de cumprimento do contrato e escolha institucional, SPPE (Tabela 11)

Tabela: Associação entre Grupo de indicador, grau de cumprimento do contrato e escolha institucional

\begin{tabular}{|ccccc}
\hline Grau/Escolha & Entidade & Estado & M unicípio & Total \\
Integralmente & 93 & 11 & 31 & 135 \\
Não & 62 & 21 & 46 & 129 \\
Parcialmente & 70 & 22 & 30 & 122 \\
Total & 225 & 54 & 107 & 386 \\
Grau/Grupo de Indicador & Pearson chi2(4)= 14.6023 & Pr $=\mathbf{0 . 0 0 6}$ & & \\
Integralmente & Baixo & Médio & Total & Total \\
Não & 29 & 12 & 94 & 135 \\
Parcialmente & 95 & 15 & 19 & 129 \\
Total & 69 & 30 & 23 & 122 \\
& 193 & 57 & 136 & 386 \\
Escolha/Grupo de Indicador & Pearson chi2(4)= 119.4399 & Pr $=\mathbf{0 . 0 0 0}$ & & \\
Entidade Privada & Baixo & $\mathbf{M e ́ d i o}$ & Total & Total \\
Estado & 73 & 45 & 107 & 225 \\
Município & 38 & 1 & 15 & 54 \\
Total & 82 & 11 & 14 & 107 \\
& 193 & 57 & 136 & 386 \\
\hline
\end{tabular}

\begin{tabular}{|cccc}
\hline \multicolumn{4}{c}{ Multiple/Joint correspondence analysis } \\
Number of obs & 386 & & \\
Total inertia & 0.17681566 & & \\
Number of axes & 2 & & \\
\multicolumn{4}{c}{ Method: Burt/adjusted inertias } \\
Dimension & Principal inertia & Percent & Cumul percent \\
dim 1 & 0.1345308 & 76.09 & 76.09 \\
$\operatorname{dim} 2$ & 0.014378 & 8.13 & 84.22 \\
$\operatorname{dim} 3$ & 0.0008273 & 0.47 & 84.68 \\
Total & 0.1768157 & 100 & \\
\hline
\end{tabular}


c) Resultados da Análise de Correspondência Múltipla - Grupo de indicador, grau de cumprimento do contrato e escolha institucional, Senaes (Tabela 12)

Tabela: Associação entre Grupo de indicador, grau de cumprimento do contrato e escolha institucional

\begin{tabular}{|c|c|c|c|c|}
\hline Grau/Escolha & Entidade & Estado & M unicípio & Total \\
\hline Integralmente & 70 & 3 & 19 & 92 \\
\hline Não & 13 & 3 & 9 & 25 \\
\hline Parcialmente & 10 & 6 & 7 & 23 \\
\hline Total & 93 & 12 & 35 & 140 \\
\hline \multicolumn{5}{|c|}{ Pearson chi2 $(4)=17.6787 \quad \operatorname{Pr}=0.001$} \\
\hline Grau/Grupo de Indicador & Baixo & Médio & Total & Total \\
\hline Integralmente & 3 & 15 & 74 & 92 \\
\hline Não & 12 & 8 & 5 & 25 \\
\hline Parcialmente & 7 & 3 & 13 & 23 \\
\hline Total & 22 & 26 & 92 & 140 \\
\hline \multicolumn{5}{|c|}{ Pearson chi2 $(4)=43.1747 \quad \operatorname{Pr}=0.000$} \\
\hline Escolha/Grupo de Indicador & Baixo & Médio & Total & Total \\
\hline Entidade Privada & 9 & 10 & 74 & 93 \\
\hline Estado & 3 & 7 & 2 & 12 \\
\hline Município & 10 & 9 & 16 & 35 \\
\hline Total & 22 & 26 & 92 & 140 \\
\hline \multicolumn{5}{|c|}{ Pearson chi2 $(4)=29.9760 \quad \operatorname{Pr}=0.000$} \\
\hline
\end{tabular}

\begin{tabular}{|cccc|}
\hline \multicolumn{4}{|c|}{ Multiple/Joint correspondence analysis } \\
Number of obs & 140 & & \\
Total inertia & 0.2162604 & & \\
Number of axes & 2 & & \\
Method: Burt/adjusted inertias & & & \\
Dimension & Principal inertia & Percent & Cumul percent \\
dim 1 & 0.1682263 & 77.79 & 77.79 \\
$\operatorname{dim} 2$ & 0.0111303 & 5.15 & 82.94 \\
$\operatorname{dim} 3$ & 0.0028205 & 1.3 & 84.24 \\
Total & 0.2162604 & 100 & \\
\hline
\end{tabular}

d) Resultados da Análise Fatorial por Componentes Principais, SPPE (Tabela 13)

Tabela: Análise fatoria por componentes principais, SPPE

\begin{tabular}{|c|c|c|c|c|}
\hline \multicolumn{5}{|c|}{ Matriz de correlação de Pearson } \\
\hline \multirow{5}{*}{$\begin{array}{c}\text { intermediacao } \\
\text { qualificacao } \\
\text { seguro desemprego } \\
\text { serviços geral }\end{array}$} & intermediacao & qualificacao & \multirow[t]{3}{*}{ seguro desemprego } & \multirow[t]{4}{*}{ serviços geral } \\
\hline & 1 & & & \\
\hline & -0.0038 & 1 & & \\
\hline & 0.5864 & -0.0021 & 1 & \\
\hline & 0.7988 & -0.002 & 0.9252 & 1 \\
\hline \multicolumn{5}{|c|}{ Factor Anlysis } \\
\hline Component & Eigenvalue & Difference & Proportion & Cumulative \\
\hline Comp1 & 2.5485 & 1.5485 & 0.6371 & 0.6371 \\
\hline Comp2 & 1.0000 & 0.5751 & 0.2500 & 0.8871 \\
\hline Comp3 & 0.4249 & 0.3983 & 0.1062 & 0.9933 \\
\hline Comp4 & 0.0266 & . & 0.0067 & 1.0000 \\
\hline Variable & Factor1 & Uniqueness & \multicolumn{2}{|c|}{ Bartlett test of sphericity } \\
\hline intermediacao & 0.8566 & 0.2663 & \multirow{4}{*}{$\begin{array}{c}\text { Chi-square }= \\
\text { Degrees of freedom }= \\
\text { p-value }=\end{array}$} & 1357.8710 \\
\hline qualificacao & -0.0046 & 1.0000 & & 6.0000 \\
\hline seguro desemprego & 0.9151 & 0.1626 & & 00000 \\
\hline serviços geral & 0.9886 & 0.0226 & & 0.0000 \\
\hline
\end{tabular}


e) Resultados da Análise de Correspondência Múltipla - Grupo de meta, grau de cumprimento do contrato e escolha institucional, SPPE (Tabela 14)

\begin{tabular}{|c|c|c|c|c|}
\hline Grau/Escolha & Entidade & Estado & Município & Total \\
\hline Integralmente & 93 & 11 & 31 & 135 \\
\hline Não & 62 & 21 & 46 & 129 \\
\hline Parcialmente & 70 & 22 & 30 & 122 \\
\hline Total & 225 & 54 & 107 & 386 \\
\hline \multicolumn{5}{|c|}{ Pearson chi2 $(4)=14.6023 \quad \operatorname{Pr}=0.006$} \\
\hline Grau/Grupo & Baixa & Média & Alta & Total \\
\hline Integralmente & 123 & 8 & 4 & 135 \\
\hline Não & 125 & 4 & 0 & 129 \\
\hline Parcialmente & 110 & 10 & 2 & 122 \\
\hline Total & 358 & 22 & 6 & 386 \\
\hline \multicolumn{5}{|c|}{ Pearson chi2 $(4)=6.9761 \quad P r=0.137$} \\
\hline Escolha/Grupo & Baixa & Média & Alta & Total \\
\hline Entidade Privada & 221 & 0 & 4 & 225 \\
\hline Estado & 54 & 0 & 0 & 54 \\
\hline Município & 83 & 22 & 2 & 107 \\
\hline Total & 358 & 22 & 6 & 386 \\
\hline \multicolumn{5}{|c|}{ Pearson chi2 $(4)=62.0352 \quad \operatorname{Pr}=0.000$} \\
\hline
\end{tabular}

\begin{tabular}{|cccc}
\hline \multicolumn{4}{c}{ Multiple/Joint correspondence analysis } \\
Number of obs & 386 & & \\
Total inertia & 0.07220515 & \\
Number of axes & 2 & & \\
& Method: Burt/adjusted inertias & \\
Dimension & Principal inertia & Percent & Cumul percent \\
dim 1 & 0.0409052 & 56.65 & 56.65 \\
dim 2 & 0.0098913 & 13.7 & 70.35 \\
dim 3 & 0.0005824 & 0.81 & 71.16 \\
Total & 0.0722051 & 100 & \\
\hline
\end{tabular}

f) Resultados da Análise de Correspondência Simples - Grupo de meta e grau de cumprimento do contrato, SPPE (Tabela 15)

Tabela: Associação entre Grupo de metas e grau de cumprimento do contrato

Number of obs

Pearson chi2(4)

Prob > chi2

Total inertia

Number of axes

Dimension

$\operatorname{dim} 1$

$\operatorname{dim} 2$

Total

\section{Correspondence analysis}

386

6.98

0.1372

0.0181

\begin{tabular}{|c|c|c|}
\hline Principal inertia & Percent & Cumul percent \\
\hline 0.0147277 & 81.49 & 81.49 \\
\hline 0.003345 & 18.51 & 100 \\
\hline 0.0180727 & 100 & \\
\hline
\end{tabular}


g) Resultados da Análise de Correspondência Simples - Grupo de meta e grau de escolha institucional, SPPE (Tabela 16)

Tabela: Associação entre Grupo de metas e escolha institucional

\begin{tabular}{|cccc|}
\hline Number of obs & Correspondence analysis & \\
Pearson chi2(4) & 386 & & \\
Prob > chi2 & 62.04 & & \\
Total inertia & 0 & & \\
Number of axes & 0.1607 & Percent & Cumul percent \\
Dimension & 2 & 98.56 & 98.56 \\
dim 1 & Principal inertia & 1.44 & 100 \\
dim 2 & 0.1583924 & 100 & \\
Total & 0.0023206 & & \\
\hline
\end{tabular}

h) Resultados da Análise Fatorial por Componentes Principais, Senaes (Tabela 17)

\begin{tabular}{|c|c|c|c|c|c|}
\hline \multicolumn{6}{|c|}{ Matriz de correlação de Pearson } \\
\hline & assessoriaees & \multirow[t]{2}{*}{ bancosassessorados } & \multirow[t]{3}{*}{ bancoscriados } & \multirow[t]{4}{*}{ estruturacaoees } & \multirow[t]{5}{*}{ familias } \\
\hline assessoriaees & 1 & & & & \\
\hline bancosassessorados & 0.2177 & 1 & & & \\
\hline bancoscriados & 0.0677 & 0.3300 & 1 & & \\
\hline estruturacaoees & 0.0366 & -0.0612 & -0.0695 & 1 & \\
\hline familias & 0.0433 & -0.0629 & -0.0274 & 0.4250 & 1 \\
\hline \multicolumn{6}{|c|}{ Factor Anlysis } \\
\hline Component & Eigenvalue & Difference & Proportion & Cumulativ & \\
\hline Factor1 & 1.51065 & 0.1486 & 0.3021 & 0.3021 & \\
\hline Factor2 & 1.36205 & 0.44 & 0.2724 & 0.5745 & \\
\hline Factor3 & 0.92204 & 0.28461 & 0.1844 & 0.7589 & \\
\hline Factor4 & 0.63744 & 0.06961 & 0.1275 & 0.8864 & \\
\hline Factor5 & 0.56783 & . & 0.1136 & 1 & \\
\hline Variable & Factor1 & Uniqueness & \multicolumn{3}{|c|}{ Bartlett test of sphericity } \\
\hline assessoriaees & -0.0866 & -0.0866 & $\begin{array}{c}\text { Chi-square } \\
=\end{array}$ & 51.3070 & \\
\hline bancosassessorados & 0.4917 & 0.4917 & $\begin{array}{l}\text { Degrees of } \\
\text { freedom = }\end{array}$ & 10.0000 & \\
\hline bancoscriados & -0.291 & -0.291 & & & \\
\hline estruturacaoees & -0.335 & -0.335 & p-value $=$ & 0.0000 & \\
\hline familias & 0.4775 & 0.4775 & & & \\
\hline
\end{tabular}


i) Resultados da Análise de Correspondência Múltipla - Grupo de meta, grau de cumprimento do contrato e escolha institucional, Senaes (Tabela 18)

Tabela: Associação entre Grupo de metas, grau de cumprimento do contrato e escolha institucional

\begin{tabular}{|c|c|c|c|c|}
\hline Grau/Escolha & Entidade & Estado & Município & Total \\
\hline Integralmente & 70 & 3 & 19 & 92 \\
\hline Não & 13 & 3 & 9 & 25 \\
\hline Parcialmente & 10 & 6 & 7 & 23 \\
\hline Total & 93 & 12 & 35 & 140 \\
\hline \multicolumn{5}{|c|}{ Pearson $\operatorname{chi} 2(4)=17.6787 \quad \operatorname{Pr}=0.001$} \\
\hline Grau/Grupo & Baixa & Média & Alta & Total \\
\hline Integralmente & 77 & 8 & 7 & 92 \\
\hline Não & 19 & 5 & 1 & 25 \\
\hline Parcialmente & 19 & 3 & 1 & 23 \\
\hline Total & 115 & 16 & 9 & 140 \\
\hline \multicolumn{5}{|c|}{ Pearson chi2 $(4)=2.9869 \quad \operatorname{Pr}=0.560$} \\
\hline Escolha/Grupo & Baixa & Média & Alta & Total \\
\hline Entidade Privada & 71 & 14 & 8 & 93 \\
\hline Estado & 12 & 0 & 0 & 12 \\
\hline Município & 32 & 2 & 1 & 35 \\
\hline Total & 115 & 16 & 9 & 140 \\
\hline \multicolumn{5}{|c|}{ Pearson chi2 $(4)=6.8041 \quad \operatorname{Pr}=0.147$} \\
\hline
\end{tabular}

\begin{tabular}{|cccc|}
\hline \multicolumn{4}{c|}{ Multiple/Joint correspondence analysis } \\
Number of obs & 140 & & \\
Total inertia & 0.06540408 & & \\
Number of axes & 2 & & \\
& Method: Burt/adjusted inertias & \\
Dimension & Principal inertia & Percent & Cumul percent \\
dim 1 & 0.039671 & 60.66 & 60.66 \\
$\operatorname{dim} 2$ & 0.0046907 & 7.17 & 67.83 \\
$\operatorname{dim} 3$ & 0.0018646 & 2.85 & 70.68 \\
Total & 0.0654041 & 100 & \\
\hline
\end{tabular}


j) Resultados da Análise de Correspondência Simples - Grupo de meta e grau de cumprimento do contrato, Senaes (Tabela 19)

Tabela: Associação entre Grupo de metas e grau de cumprimento do contrato

\begin{tabular}{|cccc}
\hline \multicolumn{4}{c}{ Correspondence analysis } \\
Number of obs & 140 & & \\
Pearson chi2(4) & 2.99 & & \\
Prob > chi2 & 0.56 & & \\
Total inertia & 0.0213 & & \\
Number of axes & 2 & Percent & Cumul percent \\
Dimension & Principal inertia & 96.75 & 96.75 \\
dim 1 & 0.0206413 & 3.25 & 100 \\
dim 2 & 0.0006937 & 100 & \\
Total & 0.021335 & & \\
\hline
\end{tabular}

k) Resultados da Análise de Correspondência Simples - Grupo de meta e escolha institucional, Senaes (Tabela 20)

Tabela: Associação entre Grupo de metas e escolha institucional

\begin{tabular}{|cccc}
\hline & Correspondence analysis & \\
Number of obs & 140 & & \\
Pearson chi2(4) & 6.8 & & \\
Prob > chi2 & 0.1466 & & \\
Total inertia & 0.0486 & & \\
Number of axes & 2 & & \\
Dimension & Principal inertia & Percent & Cumul percent \\
dim 1 & 0.0485826 & 99.96 & 99.96 \\
dim 2 & 0.0000183 & 0.04 & 100 \\
Total & 0.048601 & 100 & \\
\hline
\end{tabular}


1) Resultados da Análise de Correspondência Múltipla - Grupo de meta, grupo de indicador,grau de cumprimento do contrato e escolha institucional,SPPE (Tabela 21)

\begin{tabular}{|c|c|c|c|c|}
\hline Grau/Escolha & Entidade & Estado & Município & Total \\
\hline Integralmente & 93 & 11 & 31 & 135 \\
\hline Não & 62 & 21 & 46 & 129 \\
\hline Parcialmente & 70 & 22 & 30 & 122 \\
\hline Total & 225 & 54 & 107 & 386 \\
\hline \multicolumn{5}{|c|}{ Pearson $\operatorname{chi} 2(4)=14.6023 \quad \operatorname{Pr}=0.006$} \\
\hline Grau/Grupo de Indicador & Baixo & Médio & Total & Total \\
\hline Integralmente & 29 & 12 & 94 & 135 \\
\hline Não & 95 & 15 & 19 & 129 \\
\hline Parcialmente & 69 & 30 & 23 & 122 \\
\hline Total & 193 & 57 & 136 & 386 \\
\hline \multicolumn{5}{|c|}{ Pearson $\operatorname{chi} 2(4)=119.4399 \quad \mathrm{Pr}=0.000$} \\
\hline Grau/Grupo de Metas & Baixo & Médio & Alta & Total \\
\hline Integralmente & 123 & 8 & 4 & 135 \\
\hline Não & 125 & 4 & 0 & 129 \\
\hline Parcialmente & 110 & 10 & 2 & 122 \\
\hline Total & 358 & 22 & 6 & 386 \\
\hline \multicolumn{5}{|c|}{ Pearson chi2 $(4)=6.9761 \quad \mathrm{Pr}=0.137$} \\
\hline Escolha/Grupo de Indicador & Baixo & Médio & Total & Total \\
\hline Entidade Privada & 123 & 8 & 4 & 135 \\
\hline Estado & 125 & 4 & 0 & 129 \\
\hline Município & 110 & 10 & 2 & 122 \\
\hline Total & 358 & 22 & 6 & 386 \\
\hline \multicolumn{5}{|c|}{ Pearson chi2 $(4)=6.9761 \quad \operatorname{Pr}=0.137$} \\
\hline Escolha/Grupo de Meta & Baixo & Médio & Alta & Total \\
\hline Entidade Privada & 221 & 0 & 4 & 225 \\
\hline Estado & 54 & 0 & 0 & 54 \\
\hline Município & 83 & 22 & 2 & 107 \\
\hline Total & 358 & 22 & 6 & 386 \\
\hline \multicolumn{5}{|c|}{ Pearson chi2 $(4)=62.0352 \quad \operatorname{Pr}=0.000$} \\
\hline Grupo de Indicador/Grupo de Meta & Baixo & Médio & Alta & Total \\
\hline Baixo & 181 & 11 & 1 & 193 \\
\hline Médio & 44 & 10 & 3 & 57 \\
\hline Total & 133 & 1 & 2 & 136 \\
\hline Total & 358 & 22 & 6 & 386 \\
\hline \multicolumn{5}{|c|}{ Pearson chi2 $(4)=28.1766 \quad \operatorname{Pr}=0.000$} \\
\hline & \multicolumn{4}{|c|}{ Multiple/Joint correspondence analysis } \\
\hline & $\begin{array}{l}\text { Number of obs } \\
\text { Total inertia } \\
\text { Number of axes }\end{array}$ & $\begin{array}{c}386 \\
0.1303715 \\
2 \\
\text { d: Burt/adjusted in }\end{array}$ & nertias & \\
\hline & $\begin{array}{c}\text { Dimension } \\
\operatorname{dim} 1 \\
\operatorname{dim} 2 \\
\operatorname{dim} 3 \\
\text { Total }\end{array}$ & $\begin{array}{c}\text { Principal inertia } \\
0.0709249 \\
0.0197268 \\
0.0046756 \\
0.1303715\end{array}$ & $\begin{array}{c}\text { Percent } \\
54.4 \\
15.13 \\
3.59 \\
100\end{array}$ & $\begin{array}{c}\text { Cumul percent } \\
54.4 \\
69.53 \\
73.12\end{array}$ \\
\hline
\end{tabular}


m) Resultados da Análise de Correspondência Simples - Grupo de meta e grupo de indicador, SPPE (Tabela 22)

Tabela: Associação entre Grupo de metas e grupo de indicadores

\begin{tabular}{|cccc}
\hline & Correspondence analysis & \\
Number of obs & 386 & & \\
Pearson chi2(4) & 28.18 & & \\
Prob > chi2 & 0.0000 & & \\
Total inertia & 0.073 & & \\
Number of axes & 2 & & \\
Dimension & Principal inertia & Percent & Cumul percent \\
dim 1 & 0.0673 & 92.1800 & 92.1800 \\
dim 2 & 0.0057 & 7.8200 & 100.0000 \\
Total & 0.0730 & 100.0000 & \\
\hline
\end{tabular}

n) Resultados da Análise de Correspondência Múltipla - Grupo de meta, grupo de indicador, grau de cumprimento do contrato e escolha institucional, Senaes (Tabela 23)

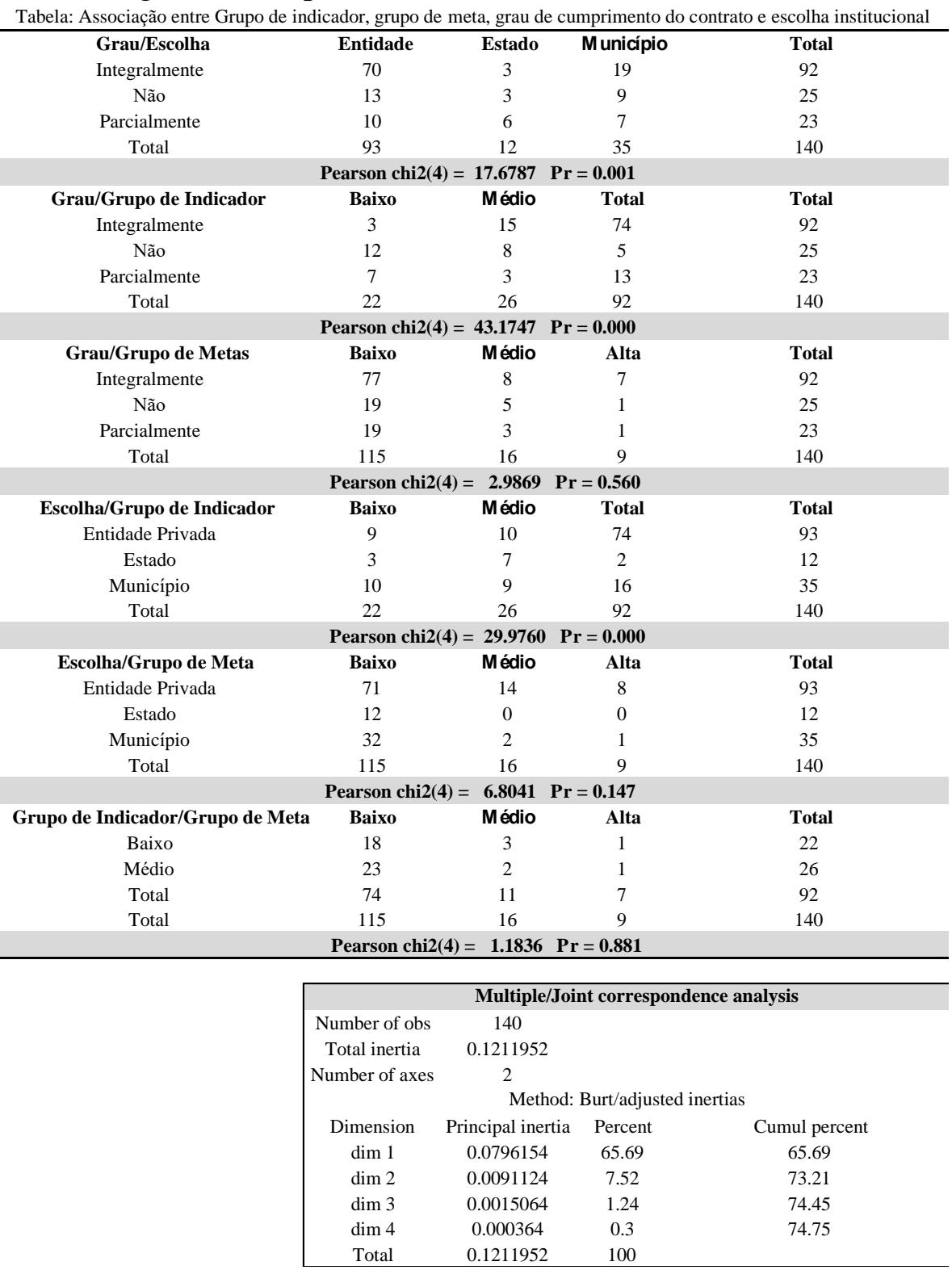


o) Resultados da Análise de Correspondência Simples - Grupo de meta e grupo de indicador, Senaes (Tabela 24)

\begin{tabular}{|cccc|}
\hline \multicolumn{4}{|c|}{ Tabela: Associação entre Grupo de metas e grupo de indicadores } \\
\hline \multicolumn{4}{|c|}{ Correspondence analysis } \\
Number of obs & 140 & & \\
Pearson chi2(4) & 1.18 & & \\
Prob > chi2 & 0.8808 & & \\
Total inertia & 0.0085 & & 78.8000 \\
Number of axes & 2 & Percent \\
Dimension & Principal inertia & 100.0000 \\
dim 1 & 0.0067 & 78.8000 & \\
dim 2 & 0.0018 & 21.2000 & \\
Total & 0.0085 & 100.0000 & \\
\hline
\end{tabular}


p) Testes de associação das variáveis qualitativas - grau de cumprimento do contrato e tipo de convenente (Tabela 26)

Tabela 26: Testes de associação das variáveis qualitativas

\begin{tabular}{|c|c|c|c|c|c|c|c|c|c|}
\hline \multirow[b]{2}{*}{ Variáveis/Categorias } & \multicolumn{2}{|c|}{$\begin{array}{c}\text { Grau de cumprimento } \\
\text { do contrato }\end{array}$} & \multicolumn{2}{|c|}{ Escolha institucional } & \multirow[b]{2}{*}{ Variáveis/Categorias } & \multicolumn{2}{|c|}{$\begin{array}{c}\text { Grau de cumprimento } \\
\text { do contrato }\end{array}$} & \multicolumn{2}{|c|}{ Escolha institucional } \\
\hline & $\begin{array}{c}\text { Estatística do } \\
\text { Qui- } \\
\text { quadrado }\end{array}$ & $\begin{array}{c}\text { P- } \\
\text { valor }\end{array}$ & $\begin{array}{l}\text { Estatística do } \\
\text { Qui-quadrado }\end{array}$ & $\begin{array}{c}\text { P- } \\
\text { valor }\end{array}$ & & $\begin{array}{c}\text { Estatística do } \\
\text { Qui- } \\
\text { quadrado }\end{array}$ & $\begin{array}{c}\text { P- } \\
\text { valor }\end{array}$ & $\begin{array}{c}\text { Estatística do } \\
\text { Qui- } \\
\text { quadrado }\end{array}$ & $\begin{array}{c}\mathbf{P}- \\
\text { valor }\end{array}$ \\
\hline Cadastro & & & & & Prestação de Contas & & & & \\
\hline Projeto & 2.93 & 0.23 & 18.93 & 0.00 & Devolução de recursos & 55.95 & 0.00 & 30.13 & 0.00 \\
\hline Emenda & 1.49 & 0.47 & 26.21 & 0.00 & $\begin{array}{l}\text { Pareceres } \\
\text { Estorno de }\end{array}$ & & & & \\
\hline Tipo de direito & 22.83 & 0.00 & 526.00 & 0.00 & Inadimplência & 6.05 & 0.05 & 0.25 & 0.88 \\
\hline Secretaria & 39.58 & 0.00 & 3.81 & 0.15 & Aprovação & 15.74 & 0.00 & 3.27 & 0.20 \\
\hline Tema & & & & & Financeiro & 36.12 & 0.00 & 4.95 & 0.08 \\
\hline Economia Solidária & 39.58 & 0.00 & 3.81 & 0.15 & Rejeição & 3.36 & 0.19 & 2.63 & 0.27 \\
\hline Microcrédito & 3.84 & 0.00 & 5.99 & 0.05 & Resgate & 4.85 & 0.09 & 1.31 & 0.52 \\
\hline Qualificação & 2.63 & 0.27 & 0.66 & 0.72 & Ressalvas & 0.59 & 0.75 & 3.02 & 0.22 \\
\hline Sine & 33.33 & 0.00 & 11.45 & 0.00 & Retificação & 2.30 & 0.32 & 1.68 & 0.43 \\
\hline Execução & & & & & Técnico & 89.09 & 0.00 & 17.03 & 0.00 \\
\hline $\begin{array}{l}\text { Pelo menos uma mudança } \\
\text { contratual }\end{array}$ & 83.90 & 0.00 & 18.70 & 0.00 & Geral & 44.59 & 0.00 & 3.55 & 0.17 \\
\hline Cronograma físico & 32.10 & 0.00 & 15.20 & 0.00 & Publicações & 5.59 & 0.06 & 0.14 & 0.93 \\
\hline Cronograma de desembolso & 42.40 & 0.00 & 3.30 & 0.19 & Relatórios de rejeição & & & & \\
\hline Metas & 0.30 & 0.87 & 2.80 & 0.24 & Beneficiários & 9.64 & 0.01 & 0.60 & 0.74 \\
\hline Outros & 9.34 & 0.01 & 1.04 & 0.60 & Bens adquiridos & 10.46 & 0.01 & 0.86 & 0.65 \\
\hline Contrapartida & 1.00 & 0.61 & 1.30 & 0.52 & Contrapartida & 13.13 & 0.00 & 2.46 & 0.29 \\
\hline Prazos (solicitação) & 12.70 & 0.00 & 29.80 & 0.00 & Bens construídos & 1.98 & 0.37 & 3.90 & 0.14 \\
\hline Plano de aplicação & 15.43 & 0.00 & 3.49 & 0.18 & Físico & 24.09 & 0.00 & 2.46 & 0.29 \\
\hline Remanejamento & 48.00 & 0.00 & 37.20 & 0.00 & Documentos & 42.53 & 0.00 & 1.68 & 0.43 \\
\hline Saldo remanescente & 3.13 & 0.21 & 1.00 & 0.59 & Financeiro & 48.18 & 0.00 & 6.93 & 0.03 \\
\hline Modificação no SICONV & 0.40 & 0.81 & 3.80 & 0.15 & Pagamentos & 48.70 & 0.00 & 0.77 & 0.68 \\
\hline Prorrogação de prazo & 44.71 & 0.00 & 73.58 & 0.00 & Receita e despesa & 42.68 & 0.00 & 4.19 & 0.12 \\
\hline Subcontratos & 199.80 & 0.00 & 19.10 & 0.00 & Serviços & 37.89 & 0.00 & 4.33 & 0.12 \\
\hline Tipo de Gasto (com recurso a & ênio) & & & & Entrega de Relatórios & & & & \\
\hline Bens & 30.34 & 0.00 & 132.63 & 0.00 & Beneficiários & 70.15 & 0.00 & 11.60 & 0.00 \\
\hline Despesa administrativa & 1.35 & 0.51 & 8.03 & 0.02 & Bens adquiridos & 64.05 & 0.00 & 9.63 & 0.01 \\
\hline Obras & 1.42 & 0.49 & 21.97 & 0.00 & Contrapartida & 37.43 & 0.00 & 4.96 & 0.08 \\
\hline Outros & 1.25 & 0.54 & 61.08 & 0.00 & Bens construídos & 7.00 & 0.00 & 1.32 & 0.52 \\
\hline Serviços & 0.40 & 0.82 & 3.89 & 0.14 & Físico & 212.73 & 0.00 & 2.30 & 0.32 \\
\hline Tributos & 8.36 & 0.02 & 35.41 & 0.00 & Documentos & 195.03 & 0.00 & 0.42 & 0.81 \\
\hline \multirow[t]{5}{*}{ Termos Aditivos } & 35.63 & 0.00 & 0.57 & 0.75 & Financeiro & 301.03 & 0.00 & 7.22 & 0.03 \\
\hline & & & & & Pagamentos & 236.45 & 0.00 & 0.08 & 0.96 \\
\hline & & & & & Receita e despesa & 153.92 & 0.00 & 0.98 & 0.61 \\
\hline & & & & & Serviços & 217.93 & 0.00 & 10.73 & 0.01 \\
\hline & & & & & $T C E$ & 0.31 & 0.85 & 0.32 & 0.85 \\
\hline
\end{tabular}


APÊNDICE C - Resultado dos modelos confirmatórios

a) Resultado do Modelo Hierárquico Linear (HLM) para todos os contratos finalizados, interceptos aleatórios (Tabela 29)

Tabela 29: Outputs dos modelos construídos

\begin{tabular}{|c|c|c|c|c|c|c|}
\hline \multicolumn{7}{|c|}{ Modelo com interceptos aleatórios } \\
\hline Indicador de repasse & Coef. & Std. Err. & $\mathbf{z}$ & $\mathbf{P}>\mathbf{z}$ & \multicolumn{2}{|c|}{ Intervalo de confiança (95\%) } \\
\hline ind_projeto & -0.11 & 0.03 & -3.66 & 0.00 & -0.16 & -0.05 \\
\hline indbenscomrecursodoconvenio & 0.10 & 0.03 & 4.03 & 0.00 & 0.05 & 0.15 \\
\hline ind_devoluçãorecurso & 0.09 & 0.02 & 3.79 & 0.00 & 0.04 & 0.13 \\
\hline documentos_ind & -0.06 & 0.03 & -1.97 & 0.05 & -0.11 & 0.00 \\
\hline financeiro_ind & 0.14 & 0.03 & 4.36 & 0.00 & 0.08 & 0.21 \\
\hline ind_subcontratos & 0.13 & 0.03 & 4.20 & 0.00 & 0.07 & 0.19 \\
\hline ind_prorrogação & 0.08 & 0.04 & 1.96 & 0.05 & 0.00 & 0.15 \\
\hline indtributoscomrecursodoconve & -0.11 & 0.03 & -3.43 & 0.00 & -0.18 & -0.05 \\
\hline PT_prazo & -0.08 & 0.03 & -2.42 & 0.02 & -0.15 & -0.02 \\
\hline indoutroscomrecursodoconveni & 0.08 & 0.03 & 2.91 & 0.00 & 0.03 & 0.14 \\
\hline quantidadededesembolsos & -0.01 & 0.00 & -5.04 & 0.00 & -0.02 & -0.01 \\
\hline quantidade_termosaditivos & 0.06 & 0.01 & 7.06 & 0.00 & 0.05 & 0.08 \\
\hline quantidade_prorrogações & 0.03 & 0.01 & 3.24 & 0.00 & 0.01 & 0.05 \\
\hline _cons & 0.38 & 0.06 & 6.21 & 0.00 & 0.26 & 0.50 \\
\hline \multicolumn{7}{|c|}{ Parâmetros de efeitos aleatórios } \\
\hline var(_cons) & 0.00 & 0.00 & - & - & 0.00 & 0.03 \\
\hline var(Residual) & 0.05 & 0.00 & - & - & 0.05 & 0.06 \\
\hline \multicolumn{7}{|c|}{ ICC } \\
\hline escolha & 0.06 & 0.06 & - & - & 0.01 & 0.38 \\
\hline LR test vs. model & ibar2( & $=8.06$ & Prob & $>=\operatorname{ch}$ & $\operatorname{bar} 2=0.0$ & \\
\hline
\end{tabular}

b) Resultado do Modelo Hierárquico Linear (HLM) para os contratos de política de emprego, interceptos aleatórios (Tabela 32)

Tabela 32: Outputs dos modelos construídos

\begin{tabular}{|c|c|c|c|c|c|c|}
\hline \multicolumn{7}{|c|}{ Modelo com interceptos aleatórios } \\
\hline Indicador de repasse & Coef. & Std. Err. & $\mathbf{z}$ & $\mathbf{P}>\mathbf{z}$ & \multicolumn{2}{|c|}{$\begin{array}{c}\text { Intervalo de confiança } \\
(95 \%)\end{array}$} \\
\hline ind_projeto & -0.13 & 0.03 & -4.00 & 0.00 & -0.19 & -0.07 \\
\hline documentos_ind & -0.09 & 0.03 & -2.76 & 0.01 & -0.15 & -0.03 \\
\hline servicos_ind & 0.18 & 0.03 & 5.27 & 0.00 & 0.11 & 0.25 \\
\hline ind_subcontratos & 0.11 & 0.03 & 3.37 & 0.00 & 0.05 & 0.18 \\
\hline indtributoscomrecursodoconve & -0.11 & 0.04 & -2.60 & 0.01 & -0.18 & -0.03 \\
\hline pt_plano & 0.19 & 0.06 & 3.29 & 0.00 & 0.07 & 0.30 \\
\hline indoutroscomrecursodoconveni & 0.08 & 0.03 & 2.50 & 0.01 & 0.02 & 0.15 \\
\hline ind_parecer_retificação & 0.27 & 0.12 & 2.24 & 0.03 & 0.03 & 0.51 \\
\hline quantidadededesembolsos & -0.02 & 0.00 & -5.94 & 0.00 & -0.02 & -0.01 \\
\hline quantidade_termosaditivos & 0.06 & 0.01 & 4.27 & 0.00 & 0.03 & 0.08 \\
\hline quantidade_prorrogações & 0.03 & 0.01 & 3.35 & 0.00 & 0.01 & 0.05 \\
\hline _cons & 0.55 & 0.07 & 8.33 & 0.00 & 0.42 & 0.68 \\
\hline \multicolumn{7}{|c|}{ Parâmetros de efeitos aleatórios } \\
\hline var(_cons) & 0.01 & 0.01 & - & - & 0.00 & 0.06 \\
\hline var(Residual) & 0.06 & 0.00 & - & - & 0.05 & 0.07 \\
\hline \multicolumn{7}{|c|}{ ICC } \\
\hline escolha & 0.10 & 0.10 & - & - & 0.01 & 0.49 \\
\hline \multicolumn{3}{|c|}{ LR test vs. modelo linear: $\operatorname{chibar} 2(01)=12.47$} & \multicolumn{4}{|c|}{ Prob $>=$ chibar $2=0.0002$} \\
\hline
\end{tabular}


c) Resultado do Modelo Hierárquico Linear (HLM) para os contratos de política de economia solidária, interceptos aleatórios (Tabela 35)

Tabela 35: Outputs dos modelos construídos

\begin{tabular}{|c|c|c|c|c|c|c|}
\hline \multicolumn{7}{|c|}{ Modelo com interceptos aleatórios } \\
\hline Indicador de repasse & Coef. & Std. Err. & $\mathbf{z}$ & $\mathbf{P}>\mathbf{z}$ & \multicolumn{2}{|c|}{ Intervalo de confiança $(95 \%)$} \\
\hline documentos_ind & 0.08 & 0.04 & 2.21 & 0.03 & 0.01 & 0.15 \\
\hline ind_subcontratos & 0.16 & 0.06 & 2.67 & 0.01 & 0.04 & 0.27 \\
\hline ind_TA & 0.11 & 0.04 & 3.12 & 0.00 & 0.04 & 0.18 \\
\hline ind_prorrogação & 0.31 & 0.05 & 6.48 & 0.00 & 0.22 & 0.41 \\
\hline ind_parecer_resgate & -0.45 & 0.17 & -2.65 & 0.01 & -0.78 & -0.12 \\
\hline indservicoscomrecursodoconve & -0.16 & 0.08 & -2.10 & 0.04 & -0.31 & -0.01 \\
\hline ind_parecer_rejeição & -0.63 & 0.16 & -3.96 & 0.00 & -0.94 & -0.32 \\
\hline _cons & 0.39 & 0.11 & 3.46 & 0.00 & 0.17 & 0.61 \\
\hline \multicolumn{7}{|c|}{ Parâmetros de efeitos aleatórios } \\
\hline var(_cons) & 0.01 & 0.01 & - & - & 0.00 & 0.10 \\
\hline var(Residual) & 0.02 & 0.00 & - & - & 0.02 & 0.03 \\
\hline \multicolumn{7}{|c|}{ ICC } \\
\hline escolha & 0.33 & 0.24 & - & - & 0.05 & 0.81 \\
\hline \multicolumn{3}{|c|}{ LR test vs. modelo linear: $\operatorname{chibar} 2(01)=19.37$} & \multicolumn{4}{|c|}{ Prob $>=$ chibar $2=0.0000$} \\
\hline
\end{tabular}

d) Matriz de Correlação para todos os contratos finalizados (Tabela 37)

Tabela 37: Matriz de Correlação (totalidade dos contratos)

\begin{tabular}{|c|c|c|c|c|c|}
\hline \multirow[b]{2}{*}{ indicador } & & indicador & \multirow[t]{2}{*}{ ind_subcontratos } & \multirow[t]{3}{*}{ ind_TA } & \multirow[t]{3}{*}{ ind_prorrogação } \\
\hline & & 1 & & & \\
\hline ind_subcontratos & $* * *$ & 0.4668 & 1 & & \\
\hline ind_prorrogação & $* * *$ & 0.5515 & 0.3453 & 0.1835 & 1 \\
\hline
\end{tabular}

Nível de Confiança: $* * *(99 \%)$

e) Matriz de Correlação para todos os contratos de políticas de emprego (Tabela 38)

Tabela 38: Matriz de Correlação (contratos de emprego)

\begin{tabular}{|lcccc|}
\hline & & indicador & ind_subcontratos & ind_TA \\
indicador & & 1 & & \\
ind_subcontratos & $* * *$ & 0.4124 & 0.2015 & 1 \\
ind_TA & $* * *$ & 0.1277 & 0.2981 & 0.1043 \\
ind_prorrogação & $* * *$ & 0.5116 & 1 & 1 \\
\hline
\end{tabular}

Nível de Confiança: *** (99\%)

f) Matriz de Correlação para todos os contratos de políticas de economia solidária (Tabela 39) 
Tabela 39: Matriz de Correlação (contratos de economia solidária)

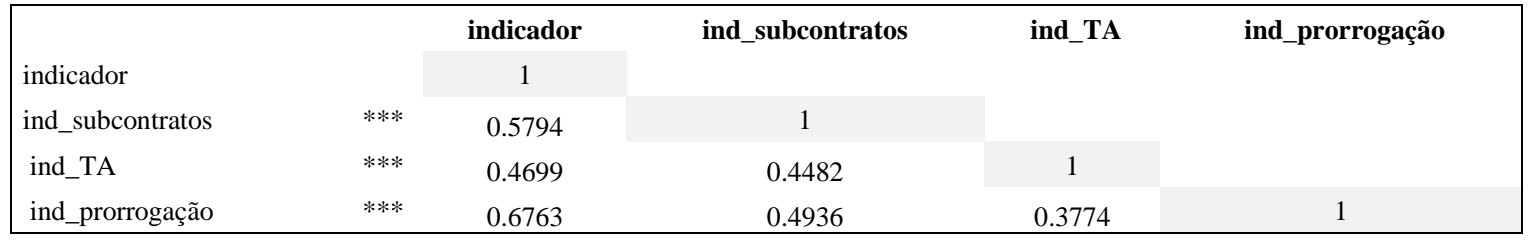

Nível de Confiança: *** $(99 \%)$

g) Resultados do Modelo Hierárquico Não Linear Logístico para todos os contratos finalizados, cumpridores versus não cumpridores, interceptos aleatórios (Tabela 41):

Tabela 41: Modelo de interceptos aleatórios

\begin{tabular}{|c|c|c|c|c|c|c|}
\hline \multicolumn{7}{|c|}{ Modelo com interceptos aleatórios } \\
\hline Cumprimento do contrato & Coef. & Std. Err. & $\mathbf{z}$ & $\mathbf{P}>\mathbf{z}$ & \multicolumn{2}{|c|}{$\begin{array}{l}\text { Intervalo de confiança } \\
\qquad(95 \%)\end{array}$} \\
\hline ind_rejeição_fisico & 2.39 & 0.76 & 3.13 & 0.00 & 0.90 & 3.89 \\
\hline ind_subcontratos & 3.00 & 0.29 & 10.43 & 0.00 & 2.43 & 3.56 \\
\hline quantidade_prorrogações & 0.33 & 0.10 & 3.21 & 0.00 & 0.13 & 0.53 \\
\hline _cons & -1.89 & 0.27 & -6.94 & 0.00 & -2.42 & -1.35 \\
\hline \multicolumn{7}{|c|}{ Parâmetros de efeitos aleatórios } \\
\hline var(_cons) & 0.00 & 0.00 & - & - & - & - \\
\hline var(Residual) & - & - & - & - & - & - \\
\hline \multicolumn{7}{|c|}{ ICC } \\
\hline escolha & 0.00 & 0.00 & - & - & - & 1 \\
\hline \multicolumn{4}{|c|}{ LR test vs. modelo logístico tradicional: $\operatorname{chibar} 2(01)=0.00$} & \multicolumn{3}{|c|}{ Prob $>=$ chibar $2=1.000$} \\
\hline
\end{tabular}

h) Resultados do Modelo Hierárquico Não Linear Logístico para todos os contratos finalizados, cumpridores versus não cumpridores, interceptos e inclinações aleatórias: não foi possível executar o modelo.

i) Resultados do Modelo Hierárquico Não Linear Logístico pata todos os contratos finalizados, cumpridores integralmente versus cumpridores parcialmente, interceptos aleatórios (Tabela 45):

Tabela 45: Modelo de interceptos aleatórios

\begin{tabular}{|c|c|c|c|c|c|c|}
\hline \multicolumn{7}{|c|}{ Modelo com interceptos aleatórios } \\
\hline \multirow{4}{*}{$\begin{array}{l}\text { Cumpridores } \\
\text { PT_prazo } \\
\text { indicador } \\
\text { _cons }\end{array}$} & \multirow{2}{*}{$\begin{array}{c}\text { Coef. } \\
1.03\end{array}$} & \multirow{2}{*}{$\begin{array}{c}\text { Std. Err. } \\
0.40\end{array}$} & \multirow{2}{*}{$\begin{array}{c}\mathbf{Z} \\
2.58\end{array}$} & \multirow{2}{*}{$\begin{array}{l}\mathbf{P}>\mathbf{z} \\
0.01\end{array}$} & \multicolumn{2}{|c|}{$\begin{array}{c}\text { Intervalo de confiança } \\
(95 \%)\end{array}$} \\
\hline & & & & & 0.25 & 1.82 \\
\hline & 4.22 & 0.49 & 8.60 & 0.00 & 3.26 & 5.19 \\
\hline & -2.96 & 0.47 & -6.28 & 0.00 & -3.89 & -2.04 \\
\hline \multicolumn{7}{|c|}{ Parâmetros de efeitos aleatórios } \\
\hline var(_cons) & 0.12 & 0.20 & - & - & 0.01 & 3.01 \\
\hline \multicolumn{7}{|c|}{ ICC } \\
\hline escolha & 0.04 & 0.06 & & & 0.00 & 0.48 \\
\hline \multicolumn{4}{|c|}{ LR test vs. modelo linear: $\operatorname{chibar} 2(01)=0.75$} & \multicolumn{3}{|c|}{ Prob $>=$ chibar2 $=0.1926$} \\
\hline
\end{tabular}


j) Resultados do Modelo Hierárquico Não Linear Logístico para todos os contratos finalizados, cumpridores integralmente versus cumpridores parcialmente, interceptos e inclinações aleatórias (Tabela 46):

Tabela 46: Modelo de interceptos e inclinações aleatórias

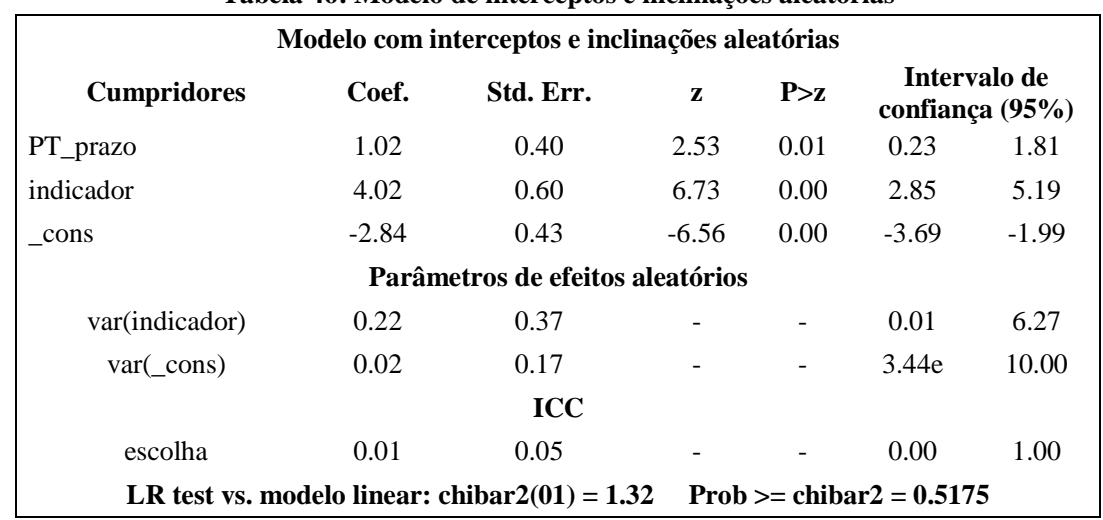

k) Resultados do Modelo Hierárquico Não Linear Logístico para os contratos da SPPE, cumpridores versus não cumpridores, interceptos aleatórios (Tabela 51):

Tabela 51: Modelo de interceptos aleatórios

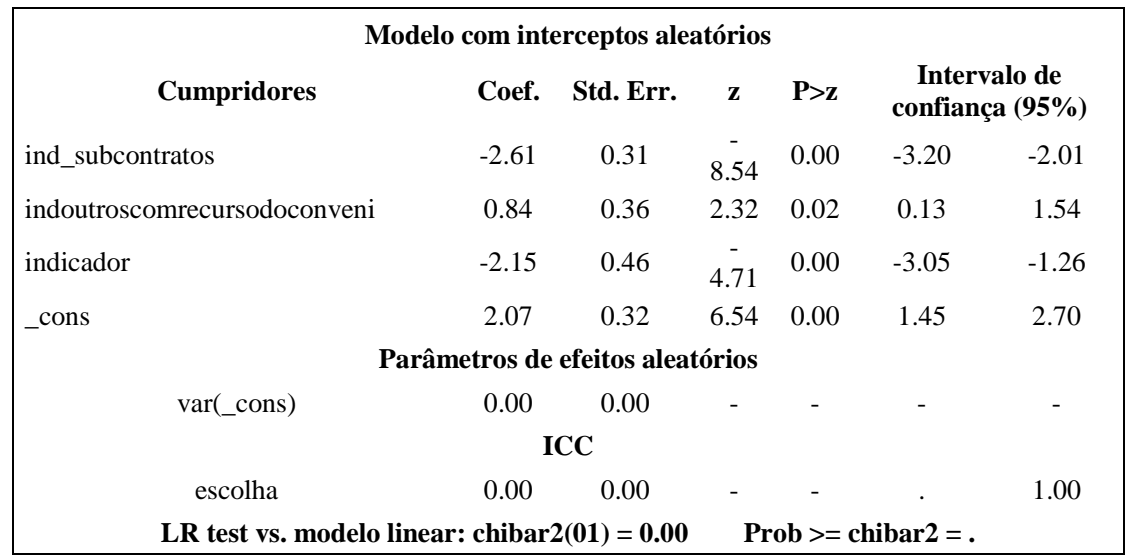

1) Resultados do Modelo Hierárquico Não Linear Logístico pata os contratos da SPPE, cumpridores versus não cumpridores, interceptos e inclinações aleatórias (Tabela 52): 
Tabela 52: Modelo de interceptos e inclinações aleatórias

\begin{tabular}{|c|c|c|c|c|c|c|}
\hline \multicolumn{7}{|c|}{ Modelo com interceptos e inclinações aleatórias } \\
\hline Cumpridores & Coef. & \multirow{2}{*}{$\begin{array}{c}\text { Std. Err. } \\
0.31\end{array}$} & \multirow{2}{*}{$\begin{array}{c}\mathbf{z} \\
- \\
8.54\end{array}$} & \multirow{2}{*}{$\begin{array}{l}\mathbf{P}>\mathbf{z} \\
0.00\end{array}$} & \multicolumn{2}{|c|}{$\begin{array}{c}\text { Intervalo de } \\
\text { confiança }(95 \%)\end{array}$} \\
\hline ind_subcontratos & -2.61 & & & & -3.20 & -2.01 \\
\hline indoutroscomrecursodoconveni & 0.84 & 0.36 & 2.32 & 0.02 & 0.13 & 1.54 \\
\hline indicador & -2.15 & 0.46 & $\begin{array}{c}- \\
4.71\end{array}$ & 0.00 & -3.05 & -1.26 \\
\hline _cons & 2.07 & 0.32 & 6.54 & 0.00 & 1.45 & 2.70 \\
\hline \multicolumn{7}{|c|}{ Parâmetros de efeitos aleatórios } \\
\hline var(indicador) & 0.00 & 0.00 & - & - & - & - \\
\hline var(_cons) & 0.00 & 0.00 & - & - & - & - \\
\hline \multicolumn{7}{|c|}{ ICC } \\
\hline escolha & 0.00 & 0.00 & - & - & . & 1.00 \\
\hline \multicolumn{3}{|c|}{ LR test vs. modelo linear: $\operatorname{chibar} 2(01)=0.00$} & \multicolumn{4}{|c|}{ Prob $>=$ chibar $2=}$. \\
\hline
\end{tabular}

m) Resultado do modelo logístico tradicional para todos os contratos finalizados, cumpridores versus não cumpridores (completo) (Tabela 54)

Tabela 54: Outputs modelo geral

\begin{tabular}{|lcccccc|}
\hline \multicolumn{7}{|c|}{ Modelo Logístico Binário Tradicional } \\
\hline \multicolumn{1}{|c}{ Cumprimento do contrato } & Chance & Std. Err. & $\mathbf{z}$ & P>z & Intervalo de confiança (95\%) \\
PT_prazo & 0.26 & 0.12 & -2.98 & 0.00 & 0.11 & 0.63 \\
ind_rejeição_pagamentos & 0.26 & 0.15 & -2.28 & 0.02 & 0.08 & 0.83 \\
PT_metas & 13.74 & 13.83 & 2.60 & 0.01 & 1.91 & 98.82 \\
indoutroscomrecursodoconveni & 2.32 & 0.79 & 2.46 & 0.01 & 1.19 & 4.52 \\
indicadorderepasse & 0.07 & 0.03 & -5.70 & 0.00 & 0.03 & 0.17 \\
ind_subcontratos & 0.08 & 0.03 & -7.74 & 0.00 & 0.04 & 0.15 \\
ind_rejeição_fisico & 0.15 & 0.13 & -2.26 & 0.02 & 0.03 & 0.78 \\
_cons & 16.94 & 6.27 & 7.65 & 0.00 & 8.21 & 34.98 \\
\hline
\end{tabular}

n) Resultado do modelo logístico tradicional para todos os contratos finalizados, integralmente versus parcialmente (completo) (Tabela 55)

Tabela 55: Outputs modelo geral

\begin{tabular}{|c|c|c|c|c|c|c|}
\hline \multicolumn{7}{|c|}{ Modelo Logístico Binário Tradicional } \\
\hline \multirow{4}{*}{$\begin{array}{l}\text { Cumpridores } \\
\text { PT_prazo } \\
\text { indicadorderepasse } \\
\text { cons }\end{array}$} & \multirow{2}{*}{$\begin{array}{c}\text { Chance } \\
2.82\end{array}$} & \multirow{2}{*}{$\begin{array}{c}\text { Std. Err. } \\
1.08\end{array}$} & \multirow{2}{*}{$\begin{array}{c}\mathbf{z} \\
2.71\end{array}$} & \multirow{2}{*}{$\begin{array}{l}\mathbf{P}>\mathbf{z} \\
0.01\end{array}$} & \multicolumn{2}{|c|}{ Intervalo de confiança $(95 \%)$} \\
\hline & & & & & 1.33 & 5.96 \\
\hline & 68.99 & 33.39 & 8.75 & 0.00 & 26.71 & 178.16 \\
\hline & 0.06 & 0.02 & -6.94 & 0.00 & 0.03 & 0.13 \\
\hline
\end{tabular}

o) Resultado do modelo logístico tradicional para todos os contratos de política de emprego, cumpridores versus não cumpridores (output completo) (Tabela 56)

Tabela 56: Outputs modelo para as políticas de emprego

\begin{tabular}{|lcccccc|}
\hline \multicolumn{4}{|c|}{ Modelo Logístico Binário Tradicional (SPPE) } \\
\hline \multicolumn{1}{|c}{ Cumprimento do contrato } & Chance & Std. Err. & $\mathbf{z}$ & $\mathbf{P}>\mathbf{z}$ & $\begin{array}{c}\text { Intervalo de confiança } \\
\mathbf{( 9 5 \% )}\end{array}$ \\
PT_metas & 16.59 & 18.22 & 2.56 & 0.01 & 1.93 & 142.78 \\
ind_subcontratos & 0.07 & 0.02 & -7.45 & 0.00 & 0.03 & 0.14 \\
ind_rejeição_documentos & 0.06 & 0.08 & -2.27 & 0.02 & 0.01 & 0.68 \\
indicador & 0.08 & 0.04 & -4.72 & 0.00 & 0.03 & 0.22 \\
indoutroscomrecursodoconveni & 2.18 & 0.84 & 2.02 & 0.04 & 1.02 & 4.65
\end{tabular}




\begin{tabular}{|lcccccc|} 
PT_prazo & 0.21 & 0.1 & -3.25 & 0.00 & 0.08 & 0.54 \\
_cons & 17.7 & 7.38 & 6.89 & 0.00 & 7.82 & 40.06 \\
\hline
\end{tabular}

p) Resultado do modelo logístico tradicional para todos os contratos de política de economia solidária, cumpridores versus não cumpridores (output completo) (Tabela 57)

Tabela 57: Outputs modelo para as políticas de economia solidária

\begin{tabular}{|lcccccc|}
\hline \multicolumn{7}{c|}{ Modelo Logístico Binário Tradicional (Senaes) } \\
\hline \multicolumn{1}{|c}{ Cumprimento do contrato } & Chance & Std. Err. & $\mathbf{z}$ & $\mathbf{P > \mathbf { z }}$ & \multicolumn{2}{c|}{$\begin{array}{c}\text { Intervalo de confiança } \\
\text { (95\%) }\end{array}$} \\
indicador & 0.02 & 0.03 & -2.87 & 0.00 & 0.00 & 0.31 \\
ind_subcontratos & 0.03 & 0.03 & -2.79 & 0.01 & 0.00 & 0.34 \\
ind_rejeição_receitadespesa & 0.14 & 0.11 & -2.61 & 0.01 & 0.03 & 0.61 \\
_cons & 233.66 & 397.29 & 3.21 & 0.00 & 8.34 & 6544.67 \\
\hline
\end{tabular}

q) Gráficos das curvas de sensibilidade e ROC referentes aos contratos cumpridos e não cumpridos das políticas de emprego monitoradas pela SPPE(Ilustração 26):
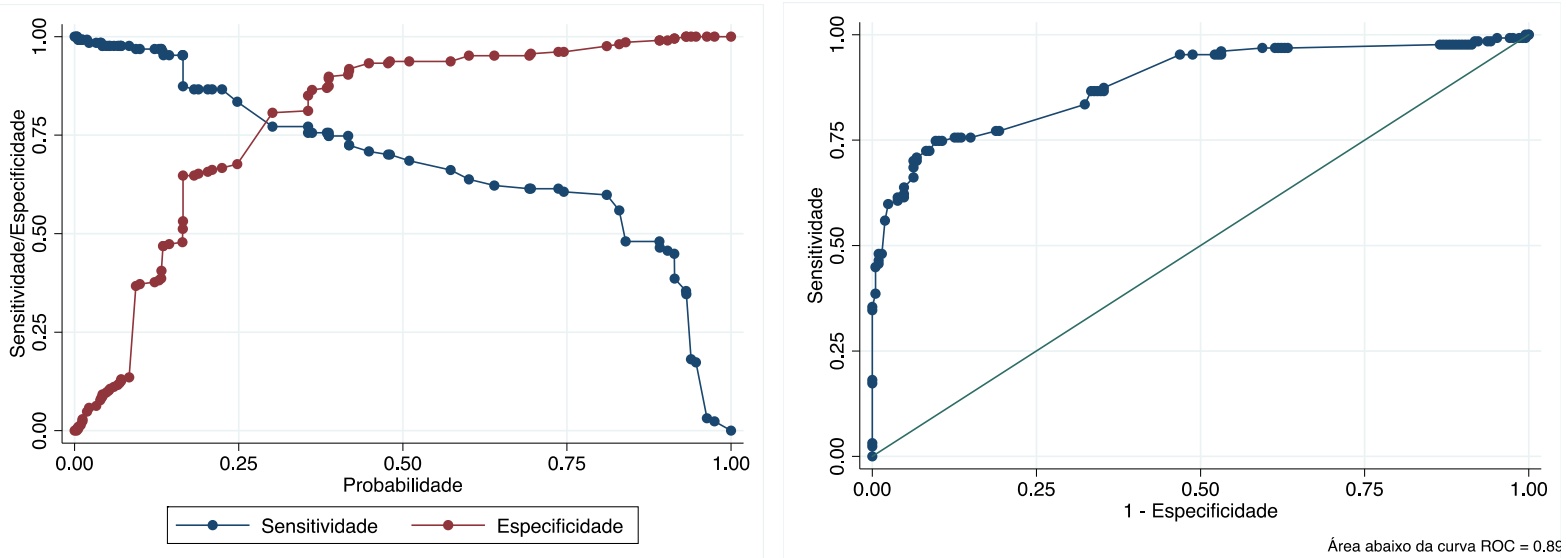

r) Gráficos das curvas de sensibilidade e ROC referentes aos contratos cumpridos e não cumpridos das políticas de economia solidária monitoradas pela Senaes (Ilustração 27): 

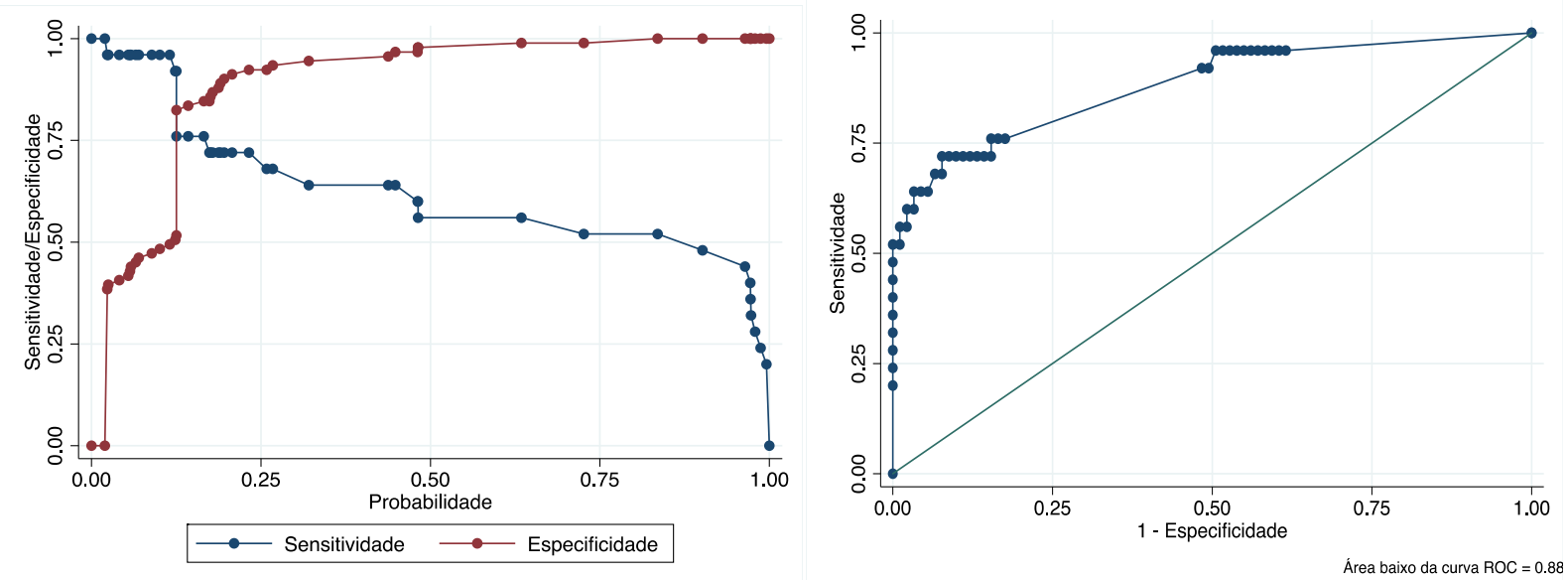

s) Resultado do modelo para dados em contagem para os contratos inflacionados de zer referentes as políticas de emprego (Tabelas 60 a 63)

Tabela 60: Resultado do modelo de meta serviços gerais

\begin{tabular}{|c|c|c|c|c|c|c|c|}
\hline \multirow[b]{2}{*}{ indicador } & \multirow{2}{*}{$\begin{array}{l}\text { Coef. } \\
6.73\end{array}$} & \multirow{2}{*}{$\begin{array}{c}\text { Std. Err. } \\
0.01\end{array}$} & \multirow{2}{*}{$\begin{array}{c}\mathbf{Z} \\
526.69\end{array}$} & \multirow{2}{*}{$\begin{array}{l}\mathbf{P}>|\mathbf{z}| \\
0.00\end{array}$} & \multicolumn{2}{|c|}{$\begin{array}{l}\text { Intervalo de confiança } \\
\qquad(95 \%)\end{array}$} & \multirow{2}{*}{$\begin{array}{c}\mathbf{e}^{\wedge} \boldsymbol{\beta} \\
834.74\end{array}$} \\
\hline & & & & & 6.70 & 6.75 & \\
\hline _Igrau_não & 2.18 & 0.01 & 310.23 & 0.00 & 2.16 & 2.19 & 8.83 \\
\hline _Igrau_parcialmente & 0.82 & 0.01 & 119.47 & 0.00 & 0.81 & 0.84 & 2.27 \\
\hline _Iescolha_município & -1.12 & 0.00 & -381.00 & 0.00 & -1.13 & -1.11 & 0.33 \\
\hline _cons & 6.47 & 0.01 & 515.14 & 0.00 & 6.44 & 6.49 & \\
\hline \multicolumn{8}{|l|}{ inflate } \\
\hline _Iescolha_município & -1.34 & 0.60 & -2.25 & 0.03 & -2.51 & -0.17 & 0.26 \\
\hline _cons & 4.00 & 0.45 & 8.86 & 0.00 & 3.12 & 4.88 & \\
\hline
\end{tabular}

Tabela 61: Resultado do modelo de meta de seguros habilitados

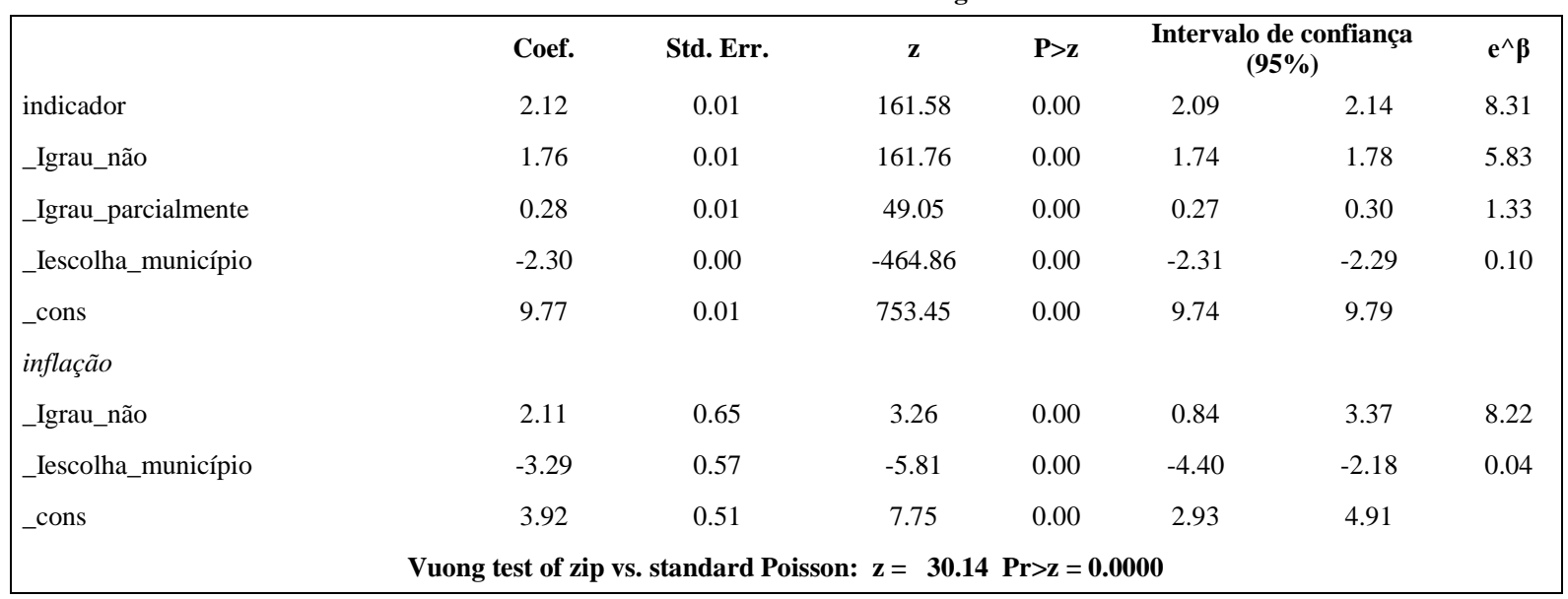


Tabela 62: Meta de trabalhados intermediados

\begin{tabular}{|lccccccc|}
\hline & Coef. & Std. Err. & $\mathbf{z}$ & $\mathbf{P > \mathbf { z }}$ & $\begin{array}{c}\text { Intervalo de confiança } \\
\text { (95\%) }\end{array}$ & $\mathbf{e}^{\wedge} \boldsymbol{\beta}$ \\
indicador & 3.46 & 0.02 & 191.05 & 0.00 & 3.43 & 3.50 & 31.86 \\
_Igrau_não & 1.56 & 0.02 & 86.09 & 0.00 & 1.52 & 1.60 & 4.76 \\
_Igrau_parcialmente & 0.96 & 0.01 & 122.01 & 0.00 & 0.94 & 0.97 & 2.60 \\
_Iescolha_município & -1.71 & 0.01 & -302.34 & 0.00 & -1.72 & -1.70 & 0.18 \\
_cons & 7.56 & 0.02 & 422.33 & 0.00 & 7.52 & 7.59 & \\
inflate & & & & & & & \\
_Igrau_não & 1.76 & 0.58 & 3.05 & 0.00 & 0.63 & 2.89 & 5.80 \\
_Iescolha_município & -3.02 & 0.52 & -5.82 & 0.00 & -4.04 & -2.00 & 0.05 \\
_cons & 3.71 & 0.45 & 8.17 & 0.00 & 2.82 & 4.60 & \\
\hline \multicolumn{2}{l}{} \\
\hline
\end{tabular}

Tabela 63: Resultado do modelo de meta de trabalhadores qualificados

\begin{tabular}{|lccccccc|}
\hline & Coef. & Std. Err. & $\mathbf{z}$ & $\mathbf{P}>\mathbf{z}$ & $\begin{array}{c}\text { Intervalo de confiança } \\
\text { (95\%) }\end{array}$ & $\mathbf{e}^{\wedge} \boldsymbol{\beta}$ \\
indicador & -5.55 & 0.00 & $1,277.80$ & 0.00 & -5.56 & -5.54 & 0.00 \\
_Igrau_não & -1.85 & 0.00 & -590.59 & 0.00 & -1.86 & -1.85 & 0.16 \\
_Igrau_parcialmente & 1.76 & 0.00 & 785.37 & 0.00 & 1.75 & 1.76 & 5.81 \\
_Iescolha_estado & -0.78 & 0.00 & -240.24 & 0.00 & -0.79 & -0.78 & 0.46 \\
_Iescolha_município & 1.56 & 0.00 & 864.88 & 0.00 & 1.56 & 1.57 & 4.78 \\
_cons & 9.23 & 0.00 & $3,170.66$ & 0.00 & 9.23 & 9.24 & \\
inflate & & & & & & & \\
_Iescolha_município & 1.16 & 0.76 & -1.53 & 0.13 & -2.65 & 0.32 & 3.20 \\
_cons & 2.80 & 0.26 & -10.84 & 0.00 & -3.30 & -2.29 & \\
\hline \multicolumn{2}{l}{} \\
\hline
\end{tabular}

t) Matriz de Correlação para todos os contratos de políticas de emprego (Tabela 65)

Tabela 65: Matriz de Correlação (contratos de emprego)

\begin{tabular}{|c|c|c|c|c|c|c|c|c|c|}
\hline \multirow[b]{2}{*}{ Indicador } & & Indicador & \multirow[t]{2}{*}{ _Igrau_parcialmente } & \multirow[t]{3}{*}{ _Igrau_não } & \multirow[t]{4}{*}{ _Iescolha_município } & \multirow[t]{5}{*}{$\begin{array}{c}\text { Serviços } \\
\text { gerais }\end{array}$} & \multirow[t]{6}{*}{ Seguro-Desemprego } & \multirow[t]{7}{*}{ Intermediação } & \multirow[t]{8}{*}{ Qualificação } \\
\hline & & 1 & & & & & & & \\
\hline _Igrau_parcialmente & $* * *$ & -0.4114 & 1 & & & & & & \\
\hline _Igrau_não & $* * *$ & -0.1024 & -0.4816 & 1 & & & & & \\
\hline _Iescolha_município & $* * *$ & -0.3483 & 0.1257 & -0.0475 & 1 & & & & \\
\hline Serviços gerais & $* *$ & 0.0975 & -0.0579 & -0.0624 & -0.0378 & 1 & & & \\
\hline Seguro-Desemprego & $* *$ & 0.0744 & -0.0564 & -0.0425 & -0.0054 & 0.9252 & 1 & & \\
\hline Intermediação & $* *$ & 0.0882 & -0.0742 & -0.0354 & 0.0112 & 0.7988 & 0.5864 & 1 & \\
\hline Qualificação & & -0.0679 & -0.0364 & 0.0743 & 0.0764 & -0.002 & -0.0021 & -0.0038 & 1 \\
\hline
\end{tabular}

Nível de Confiança: *** $(99 \%) ; * *(95 \%)$ 
u) Resultados do Modelo Hierárquico Não Linear para dados em contagem para os contratos da Senaes, interceptos aleatórios (Tabelas 66 a 69):

Tabela 66: Meta de assessoria de EES

\begin{tabular}{|c|c|c|c|c|c|c|}
\hline \multicolumn{7}{|c|}{ Modelo com interceptos aleatórios } \\
\hline assessoriadeees & Coef. & Std. Err. & $\mathbf{z}$ & $\mathbf{P}>\mathbf{z}$ & \multicolumn{2}{|c|}{$\begin{array}{c}\text { Intervalo de confiança } \\
(95 \%)\end{array}$} \\
\hline indicador & -1.49 & 0.04 & -36.91 & 0.00 & -1.57 & -1.41 \\
\hline _Igrau_2 & -0.37 & 0.03 & -11.77 & 0.00 & -0.43 & -0.30 \\
\hline _Igrau_3 & -1.09 & 0.04 & -27.94 & 0.00 & -1.16 & -1.01 \\
\hline _cons & 5.51 & 0.28 & 19.74 & 0.00 & 4.96 & 6.06 \\
\hline \multicolumn{7}{|c|}{ Parâmetros de efeitos aleatórios } \\
\hline var(_cons) & 0.23 & 0.19 & - & - & 0.05 & 1.15 \\
\hline LR test & lelo P & 1: $\operatorname{chi} 2(2)=$ & & Prob & ii2 $=0.0$ & \\
\hline
\end{tabular}

Tabela 67: Meta de estruturação de EES

\begin{tabular}{|c|c|c|c|c|c|c|}
\hline & Mode & $m$ interce & aleató & & & \\
\hline estruturacaodeees & Coef. & Std. Err. & $\mathbf{z}$ & $\mathbf{P}>\mathbf{Z}$ & \multicolumn{2}{|c|}{$\begin{array}{c}\text { Intervalo de confiança } \\
(95 \%)\end{array}$} \\
\hline & 1.80 & 0.17 & 10.84 & 0.00 & 1.48 & 2.13 \\
\hline _Igrau_não & -0.08 & 0.09 & -0.84 & 0.40 & -0.25 & 0.10 \\
\hline _Igrau_parcialmente & -0.79 & 0.09 & -8.30 & 0.00 & -0.98 & -0.60 \\
\hline _cons & 1.05 & 0.27 & 3.89 & 0.00 & 0.52 & 1.58 \\
\hline & Parâ & ros de efei & leatór & & & \\
\hline var(_cons) & 0.15 & 0.12 & - & - & 0.03 & 0.74 \\
\hline LR test vs & Poisso & $\operatorname{hi} 2(2)=23$ & & Prob & $2=0.00$ & \\
\hline
\end{tabular}

Tabela 68: Meta de assessoria a bancos comunitários

\begin{tabular}{|c|c|c|c|c|c|c|}
\hline \multicolumn{7}{|c|}{ Modelo com interceptos aleatórios } \\
\hline bancosfunfoscomunitariosassess & Coef. & Std. Err. & $\mathbf{z}$ & $\mathbf{P}>\mathbf{z}$ & \multicolumn{2}{|c|}{$\begin{array}{c}\text { Intervalo de confiança } \\
(95 \%)\end{array}$} \\
\hline indicador & 0.87 & 0.22 & 3.89 & 0.00 & 0.43 & 1.31 \\
\hline _Igrau_não & 0.69 & 0.13 & 5.33 & 0.00 & 0.43 & 0.94 \\
\hline _Igrau_parcialmente & 0.69 & 0.12 & 5.74 & 0.00 & 0.45 & 0.92 \\
\hline _cons & -1.25 & 0.88 & -1.42 & 0.16 & -2.97 & 0.47 \\
\hline \multicolumn{7}{|c|}{ Parâmetros de efeitos aleatórios } \\
\hline var(_cons) & 2.13 & 1.80 & - & - & 0.41 & 11.11 \\
\hline \multicolumn{7}{|c|}{ LR test vs. modelo Poisson: $\operatorname{chi} 2(2)=297.95$} \\
\hline
\end{tabular}

Tabela 69: Meta de estruturação de bancos comunitários

\begin{tabular}{|lccccccc|}
\multicolumn{2}{|c}{ Modelo com interceptos aleatórios } & & \multicolumn{2}{c|}{$\begin{array}{c}\text { Intervalo de confiança } \\
\text { (95\%) }\end{array}$} \\
bancosfundoscomunitarioscriaca & Coef. & Std. Err. & $\mathbf{z}$ & P>z & & 2.22 \\
indicador & 1.33 & 0.45 & 2.93 & 0.00 & 0.44 & 0.54 \\
_Igrau_não & 0.08 & 0.24 & 0.33 & 0.75 & -0.38 & 0.27
\end{tabular}




\begin{tabular}{|c|c|c|c|c|c|c|c|}
\hline _cons & & -1.24 & 0.57 & -2.19 & 0.03 & -2.35 & -0.13 \\
\hline \multicolumn{8}{|c|}{ Parâmetros de efeitos aleatórios } \\
\hline & $\operatorname{var}\left(\_c o n s\right)$ & 0.39 & 0.36 & - & - & 0.07 & 2.32 \\
\hline \multicolumn{4}{|c|}{ LR test vs. modelo Poisson:chi2(2) = 33.09 } & \multicolumn{3}{|c|}{ Prob $>$ chi $2=0.0000$} & \\
\hline
\end{tabular}

v) Resultados do Modelo Hierárquico Não Linear para dados em contagem para os contratos da Senaes, interceptos e inclinações aleatórias (Tabelas 70 a 73):

Tabela 70: Meta de assessoria de EES

Modelo com interceptos aleatórios

Não converge

Tabela 71: Meta de estruturação de EES

\begin{tabular}{|c|c|c|c|c|c|c|}
\hline \multirow[b]{3}{*}{ indicador } & \multicolumn{6}{|c|}{ Modelo com interceptos e inclinações aleatórias } \\
\hline & \multirow{2}{*}{$\begin{array}{l}\text { Coef. } \\
0.49\end{array}$} & \multirow{2}{*}{$\begin{array}{c}\text { Std. Err. } \\
1.23\end{array}$} & \multirow{2}{*}{$\begin{array}{c}\mathbf{z} \\
0.40\end{array}$} & \multirow{2}{*}{$\begin{array}{l}\mathbf{P}>\mathbf{z} \\
0.69\end{array}$} & \multicolumn{2}{|c|}{$\begin{array}{l}\text { Intervalo de confiança } \\
(\mathbf{9 5 \% )}\end{array}$} \\
\hline & & & & & -1.93 & 2.90 \\
\hline _Igrau_não & -0.18 & 0.10 & -1.86 & 0.06 & -0.37 & 0.01 \\
\hline _Igrau_parcialmente & -0.81 & 0.09 & -8.53 & 0.00 & -0.99 & -0.62 \\
\hline _cons & 1.86 & 1.13 & 1.65 & 0.10 & -0.35 & 4.07 \\
\hline \multicolumn{7}{|c|}{ Parâmetros de efeitos aleatórios } \\
\hline var(indicador) & 7.23 & 4.93 & - & - & 1.90 & 27.48 \\
\hline var(_cons) & 6.03 & 4.37 & - & - & 1.46 & 24.99 \\
\hline \multicolumn{4}{|c|}{ LR test vs. modelo Poisson: chi $2(2)=443.94$} & \multicolumn{3}{|c|}{ Prob $>$ chi $2=0.0000$} \\
\hline
\end{tabular}

Tabela 72: Meta de assessoria a bancos comunitários

\begin{tabular}{|c|c|c|c|c|c|c|}
\hline \multicolumn{7}{|c|}{ Modelo com interceptos e inclinações aleatórias } \\
\hline \multirow[b]{2}{*}{ indicador } & \multirow{2}{*}{$\begin{array}{c}\text { Coef. } \\
1.52\end{array}$} & \multirow{2}{*}{$\begin{array}{c}\text { Std. Err. } \\
1.00\end{array}$} & \multirow{2}{*}{$\begin{array}{c}\mathbf{z} \\
1.51\end{array}$} & \multirow{2}{*}{$\begin{array}{l}\mathbf{P}>\mathbf{z} \\
0.13\end{array}$} & \multicolumn{2}{|c|}{$\begin{array}{c}\text { Intervalo de confiança } \\
(95 \%)\end{array}$} \\
\hline & & & & & -0.45 & 3.48 \\
\hline _Igrau_não & 0.69 & 0.13 & 5.34 & 0.00 & 0.44 & 0.94 \\
\hline _Igrau_parcialmente & 0.69 & 0.12 & 5.78 & 0.00 & 0.46 & 0.93 \\
\hline _cons & 0.12 & 0.99 & 0.13 & 0.90 & -1.81 & 2.05 \\
\hline \multicolumn{7}{|c|}{ Parâmetros de efeitos aleatórios } \\
\hline var(indicador) & 2.97 & 2.31 & - & - & 0.65 & 13.66 \\
\hline var(_cons) & 2.89 & 2.05 & - & - & 0.72 & 11.63 \\
\hline \multicolumn{4}{|c|}{ LR test vs. modelo Poisson: $\operatorname{chi} 2(2)=302.45$} & \multicolumn{3}{|c|}{ Prob $>$ chi $2=0.0000$} \\
\hline
\end{tabular}

Tabela 73: meta de estruturação de bancos comunitários 


\begin{tabular}{|c|c|c|c|c|c|c|}
\hline \multirow[b]{2}{*}{ indicador } & \multirow{2}{*}{$\begin{array}{c}\text { Coef. } \\
1.17\end{array}$} & \multirow{2}{*}{$\begin{array}{c}\text { Std. Err. } \\
1.15\end{array}$} & \multirow{2}{*}{$\begin{array}{c}\mathbf{z} \\
1.02\end{array}$} & \multirow{2}{*}{$\begin{array}{l}\mathbf{P}>\mathbf{z} \\
0.31\end{array}$} & \multicolumn{2}{|c|}{$\begin{array}{l}\text { Intervalo de confiança } \\
\qquad(95 \%)\end{array}$} \\
\hline & & & & & -1.09 & 3.43 \\
\hline _Igrau_não & 0.11 & 0.24 & 0.44 & 0.66 & -0.36 & 0.57 \\
\hline _Igrau_parcialmente & -0.10 & 0.23 & -0.44 & 0.66 & -0.56 & 0.35 \\
\hline _cons & -0.30 & 1.12 & -0.27 & 0.79 & -2.49 & 1.89 \\
\hline \multicolumn{7}{|c|}{ Parâmetros de efeitos aleatórios } \\
\hline var(indicador) & 4.35 & 3.52 & - & - & 0.89 & 21.29 \\
\hline var(_cons) & 4.05 & 3.44 & - & - & 0.77 & 21.38 \\
\hline \multicolumn{4}{|c|}{ LR test vs. modelo Poisson: $\operatorname{chi} 2(2)=64.38$} & \multicolumn{3}{|c|}{ Prob $>$ chi $2=0.0000$} \\
\hline
\end{tabular}

w) Resultado do modelo para dados em contagem inflacionados de zero para as metas de economia solidária (Tabelas 76 a 79)

Tabela 76: Meta de assessoria de bancos comunitários

\begin{tabular}{|c|c|c|c|c|c|c|}
\hline \multirow[b]{2}{*}{ indicador } & \multirow{2}{*}{$\begin{array}{c}\text { Coef. } \\
0.45\end{array}$} & \multirow{2}{*}{$\begin{array}{c}\text { Std. Err. } \\
0.27\end{array}$} & \multirow{2}{*}{$\begin{array}{c}\mathbf{z} \\
1.68\end{array}$} & \multirow{2}{*}{$\begin{array}{l}\mathbf{P}>\mathbf{z} \\
0.09\end{array}$} & \multicolumn{2}{|c|}{$\begin{array}{c}\text { Intervalo de confiança } \\
(95 \%)\end{array}$} \\
\hline & & & & & -0.08 & 0.98 \\
\hline _Igrau_2 & 0.20 & 0.13 & 1.61 & 0.11 & -0.04 & 0.45 \\
\hline _Igrau_3 & -0.36 & 0.12 & -2.99 & 0.00 & -0.59 & -0.12 \\
\hline _Iescolha_2 & -2.62 & 0.63 & -4.17 & 0.00 & -3.86 & -1.39 \\
\hline _Iescolha_3 & -2.99 & 0.61 & -4.88 & 0.00 & -4.19 & -1.79 \\
\hline \multicolumn{7}{|l|}{ inflate } \\
\hline indicador & 0.51 & 1.02 & 0.50 & 0.62 & -1.48 & 2.50 \\
\hline _Igrau_2 & -0.09 & 0.70 & -0.13 & 0.90 & -1.47 & 1.29 \\
\hline _Igrau_3 & -1.08 & 0.65 & -1.67 & 0.09 & -2.34 & 0.19 \\
\hline _Iescolha_2 & 0.20 & 1.00 & 0.20 & 0.84 & -1.76 & 2.16 \\
\hline _Iescolha_3 & 0.39 & 0.83 & 0.47 & 0.64 & -1.23 & 2.01 \\
\hline _cons & 0.63 & 1.03 & 0.62 & 0.54 & -1.38 & 2.65 \\
\hline Vuong test & Poiss & 4.10 $\operatorname{Pr}>\mathrm{Z}$ & & & & \\
\hline
\end{tabular}

Tabela 77: Metas de assessoria de EES

\begin{tabular}{|c|c|c|c|c|c|c|}
\hline \multirow[b]{2}{*}{ indicador } & \multirow{2}{*}{$\begin{array}{l}\text { Coef. } \\
-1.86\end{array}$} & \multirow{2}{*}{$\begin{array}{c}\text { Std. Err. } \\
0.04\end{array}$} & \multirow{2}{*}{$\begin{array}{c}\mathbf{z} \\
-41.57\end{array}$} & \multirow{2}{*}{$\begin{array}{l}\mathbf{P}>\mathbf{z} \\
0.00\end{array}$} & \multicolumn{2}{|c|}{$\begin{array}{c}\text { Intervalo de confiança } \\
(95 \%)\end{array}$} \\
\hline & & & & & -1.94 & -1.77 \\
\hline _Igrau_2 & -0.90 & 0.04 & -25.39 & 0.00 & -0.97 & -0.83 \\
\hline _Igrau_3 & -1.27 & 0.04 & -31.63 & 0.00 & -1.34 & -1.19 \\
\hline _Iescolha_2 & -1.40 & 0.05 & -25.63 & 0.00 & -1.51 & -1.30 \\
\hline _Iescolha_3 & -0.40 & 0.02 & -17.60 & 0.00 & -0.45 & -0.36 \\
\hline _cons & 6.92 & 0.04 & 154.61 & 0.00 & 6.84 & 7.01 \\
\hline \multicolumn{7}{|l|}{ inflate } \\
\hline indicador & -0.27 & 0.89 & -0.30 & 0.76 & -2.01 & 1.47 \\
\hline _Igrau_2 & -0.54 & 0.62 & -0.87 & 0.39 & -1.75 & 0.68 \\
\hline _Igrau_3 & -0.46 & 0.56 & -0.82 & 0.41 & -1.56 & 0.64 \\
\hline _Iescolha_2 & -0.94 & 0.85 & -1.11 & 0.27 & -2.60 & 0.72 \\
\hline _Iescolha_3 & -0.09 & 0.44 & -0.21 & 0.83 & -0.96 & 0.77 \\
\hline _cons & -0.14 & 0.90 & -0.16 & 0.88 & -1.90 & 1.62 \\
\hline
\end{tabular}




\begin{tabular}{|lcccccc|}
\hline & Coef. & Std. Err. & $\mathbf{z}$ & $\mathbf{P}>\mathbf{z}$ & \multicolumn{2}{c|}{ Intervalo de confiança } \\
(95\%) & \\
indicador & -3.65 & 0.85 & -4.31 & 0.00 & -5.31 & -1.99 \\
_Igrau_2 & -0.24 & 0.24 & -1.00 & 0.32 & -0.71 & 0.23 \\
_Igrau_3 & 0.20 & 0.27 & 0.75 & 0.45 & -0.32 & 0.73 \\
_Iescolha_2 & -2.65 & 0.62 & -4.29 & 0.00 & -3.86 & -1.44 \\
_Iescolha_3 & -4.11 & 0.75 & -5.49 & 0.00 & -5.58 & -2.64 \\
_cons & 6.08 & 0.84 & 7.22 & 0.00 & 4.43 & 7.73 \\
inflate & & & & & & \\
indicador & -3.18 & 2.02 & -1.57 & 0.12 & -7.14 & 0.79 \\
_Igrau_2 & -0.85 & 0.77 & -1.11 & 0.27 & -2.36 & 0.66 \\
-Igrau_3 & -0.44 & 0.72 & -0.61 & 0.54 & -1.84 & 0.97 \\
_Iescolha_2 & -0.51 & 1.09 & -0.47 & 0.64 & -2.65 & 1.62 \\
_Iescolha_3 & -2.18 & 1.61 & -1.35 & 0.18 & -5.33 & 0.98 \\
_cons & 4.58 & 2.01 & 2.27 & 0.02 & 0.63 & 8.53 \\
Vuong test of zip vs. standard Poisson: $\mathrm{z}=$ & $3.48 \mathrm{Pr}>\mathrm{z}=0.0002$ & & & \\
\hline
\end{tabular}

Tabela 79: Meta de estruturação de EES

\begin{tabular}{|c|c|c|c|c|c|c|}
\hline \multirow{2}{*}{$\begin{array}{l}\text { estruturacaodeees } \\
\text { indicador }\end{array}$} & \multirow{2}{*}{$\begin{array}{l}\text { Coef. } \\
2.50\end{array}$} & \multirow{2}{*}{$\begin{array}{c}\text { Std. Err. } \\
0.17\end{array}$} & \multirow{2}{*}{$\begin{array}{c}\mathbf{z} \\
14.70\end{array}$} & \multirow{2}{*}{$\begin{array}{l}\mathbf{P}>\mathbf{z} \\
0.00\end{array}$} & \multicolumn{2}{|c|}{$\begin{array}{c}\text { Intervalo de confiança } \\
(95 \%)\end{array}$} \\
\hline & & & & & 2.17 & 2.83 \\
\hline _Igrau_2 & -0.01 & 0.09 & -0.08 & 0.94 & -0.18 & 0.17 \\
\hline _Igrau_3 & -0.56 & 0.10 & -5.80 & 0.00 & -0.75 & -0.37 \\
\hline _Iescolha_2 & 0.37 & 0.13 & 2.98 & 0.00 & 0.13 & 0.62 \\
\hline _Iescolha_3 & 0.98 & 0.06 & 16.94 & 0.00 & 0.87 & 1.09 \\
\hline _cons & 0.67 & 0.17 & 3.92 & 0.00 & 0.34 & 1.01 \\
\hline \multicolumn{7}{|l|}{ inflate } \\
\hline indicador & 1.33 & 0.91 & 1.46 & 0.15 & -0.46 & 3.12 \\
\hline _Igrau_2 & 0.37 & 0.57 & 0.64 & 0.52 & -0.76 & 1.49 \\
\hline _Igrau_3 & 0.66 & 0.53 & 1.24 & 0.21 & -0.38 & 1.70 \\
\hline _Iescolha_2 & -0.10 & 0.69 & -0.15 & 0.88 & -1.45 & 1.24 \\
\hline _Iescolha_3 & -0.04 & 0.44 & -0.09 & 0.93 & -0.90 & 0.81 \\
\hline _cons & -1.20 & 0.93 & -1.30 & 0.19 & -3.02 & 0.61 \\
\hline Vuong test of zip vs. standar & $\mathrm{z}=$ & $>\mathrm{z}=0.0002$ & & & & \\
\hline
\end{tabular}

x) Matriz de Correlação para todos os contratos de políticas de emprego (Tabela 81)

Tabela 81: Matriz de Correlação (contratos de economia solidária)

\begin{tabular}{|c|c|c|c|c|c|c|c|c|}
\hline \multirow[b]{2}{*}{ Indicador } & \multirow{2}{*}{$\begin{array}{c}* * \\
*\end{array}$} & $\begin{array}{c}\text { Indicado } \\
\mathrm{r}\end{array}$ & \multirow[t]{2}{*}{$\begin{array}{c}\text { _Iescolha_estad } \\
\text { o }\end{array}$} & \multirow[t]{3}{*}{$\begin{array}{c}\text { _Iescolha_municípi } \\
\text { o }\end{array}$} & \multirow[t]{4}{*}{$\begin{array}{c}\text { Assessoria } \\
\text { a BC }\end{array}$} & \multirow[t]{5}{*}{$\begin{array}{c}\text { Estruturação } \\
\text { de BC }\end{array}$} & \multirow[t]{6}{*}{$\begin{array}{c}\text { Assessoria } \\
\text { de EES }\end{array}$} & \multirow[t]{7}{*}{$\begin{array}{c}\text { Estruturação } \\
\text { de EES }\end{array}$} \\
\hline & & 1 & & & & & & \\
\hline _Iescolha_estado & $\begin{array}{c}* * \\
* *\end{array}$ & -0.2047 & 1 & & & & & \\
\hline $\begin{array}{l}\text { _Iescolha_municípi } \\
\text { o }\end{array}$ & $\begin{array}{l}* * \\
*\end{array}$ & -0.2585 & -0.1768 & 1 & & & & \\
\hline Assessoria a BC & $* *$ & 0.0896 & -0.0898 & -0.1784 & 1 & & & \\
\hline Estruturação de BC & $* *$ & 0.1028 & -0.0592 & -0.1187 & 0.33 & 1 & & \\
\hline Assessoria de EES & $* *$ & -0.0844 & -0.0643 & -0.0173 & 0.2177 & 0.0677 & 1 & \\
\hline $\begin{array}{l}\text { Estruturação de } \\
\text { EES }\end{array}$ & $* *$ & 0.072 & -0.0307 & 0.0819 & -0.0612 & -0.0695 & 0.0366 & 1 \\
\hline
\end{tabular}

Nível de Confiança: *** $(99 \%) ; * *(95 \%)$ 